Report of Investigation 2021-5

\title{
GEOLOGIC INVESTIGATION OF THE LADUE RIVER-MOUNT FAIRPLAY AREA, EASTERN ALASKA
}

Evan Twelker, Editor
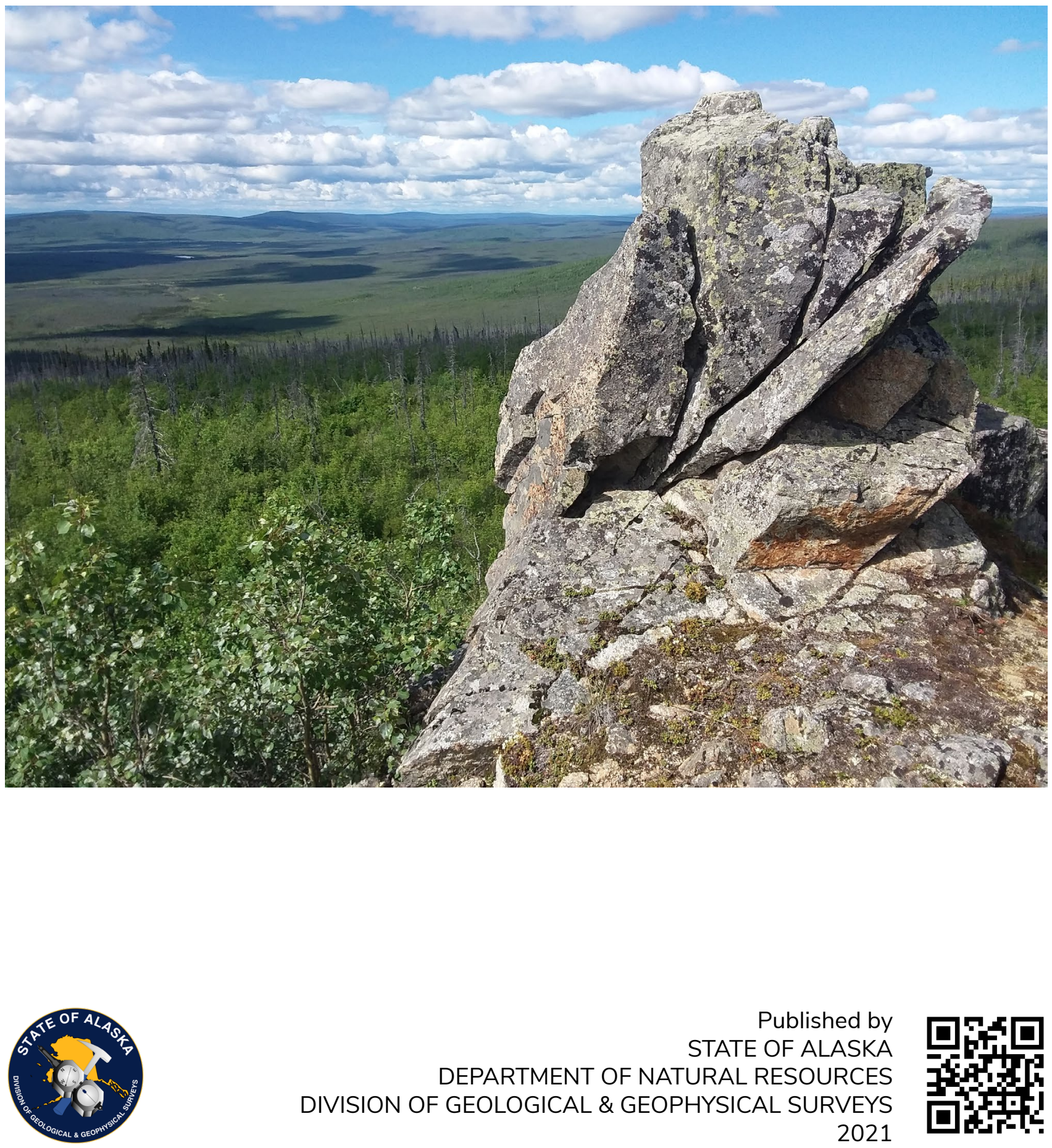



\section{GEOLOGIC INVESTIGATION OF THE LADUE RIVER-MOUNT FAIRPLAY AREA, EASTERN ALASKA}

Evan Twelker, Editor

Report of Investigation 2021-5

State of Alaska

Department of Natural Resources

Division of Geological \& Geophysical Surveys 


\section{STATE OF ALASKA}

Mike Dunleavy, Governor

\section{DEPARTMENT OF NATURAL RESOURCES}

Corri A. Feige, Commissioner

\section{DIVISION OF GEOLOGICAL \& GEOPHYSICAL SURVEYS}

Steve Masterman, State Geologist and Director

Publications produced by the Division of Geological \&

Geophysical Surveys (DGGS) are available for free download

from the DGGS website (dggs.alaska.gov). Publications on

hard-copy or digital media can be examined or purchased in

the Fairbanks office:

Alaska Division of Geological \& Geophysical Surveys

3354 College Rd., Fairbanks, Alaska 99709-3707

Phone: (907) 451-5010 Fax (907) 451-5050

dggspubs@alaska.gov|dggs.alaska.gov

\section{DGGS publications are also available at:}

Alaska State Library,

Historical Collections \& Talking Book Center

395 Whittier Street

Juneau, Alaska 99811

Alaska Resource Library and Information Services (ARLIS)

3150 C Street, Suite 100

Anchorage, Alaska 99503

\section{Suggested citation:}

Twelker, Evan, ed., 2021, Geologic investigation of the Ladue River-Mount Fairplay area, eastern Alaska: Alaska Division of Geological \& Geophysical Surveys Report of Investigation 2021-5. https://doi.org/10.14509/30734
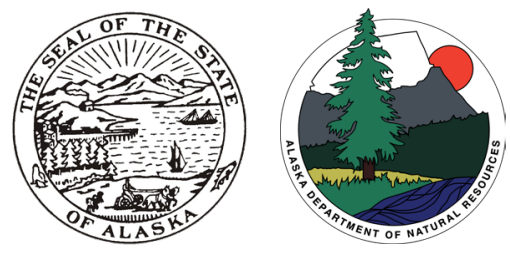


\section{Contents}

Chapter A: Bedrock Geologic Map of the Ladue River-Mount Fairplay Area, Tanacross and

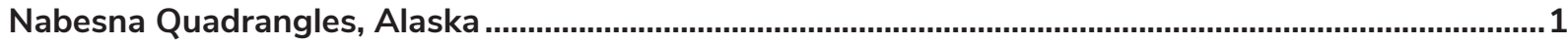

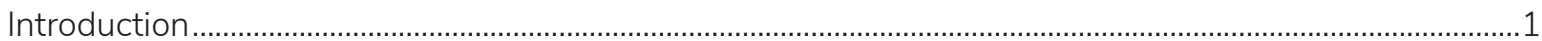

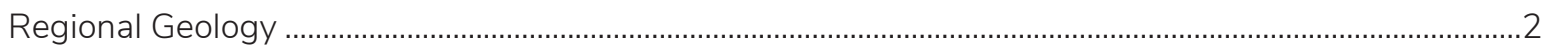

Parautochthonous North American Assemblages................................................................................

Lake George Assemblage ........................................................................................................

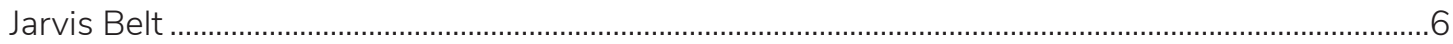

Yukon Tanana Terrane Assemblages ......................................................................................................

Snowcap and Finlayson Assemblages..................................................................................................

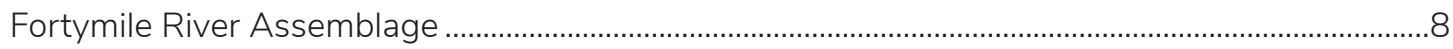

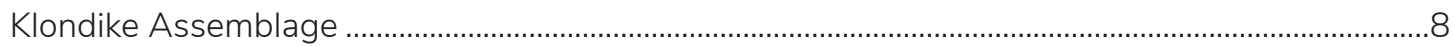

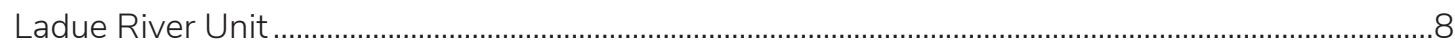

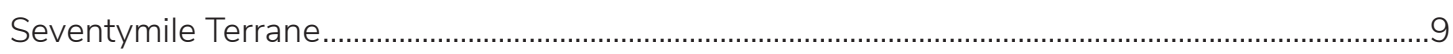

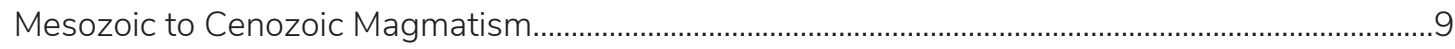

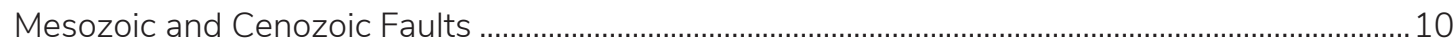

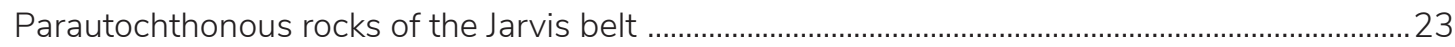

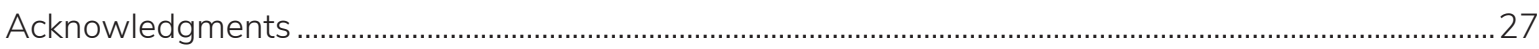

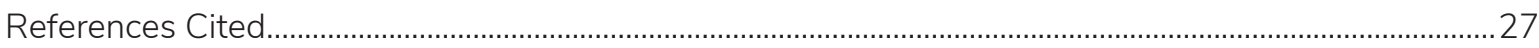

Chapter B: Metamorphism of the Ladue River-Mount Fairplay area ............................................................. 33

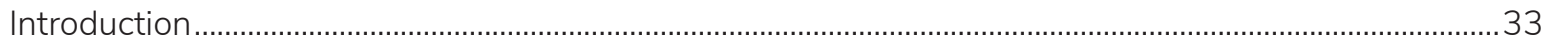

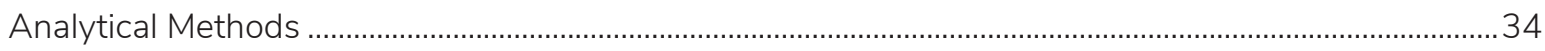

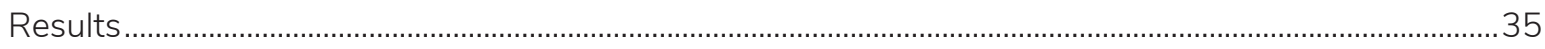

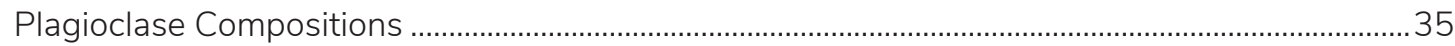

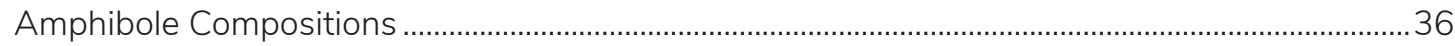

Discussion of Metamorphic Assemblages............................................................................................................ 36

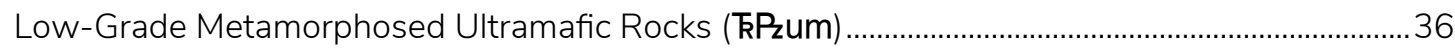

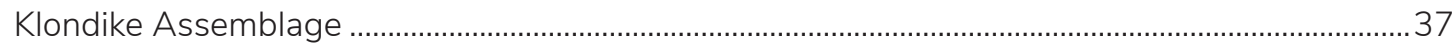

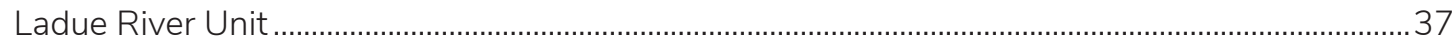

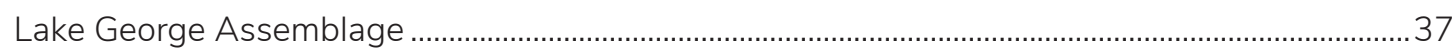

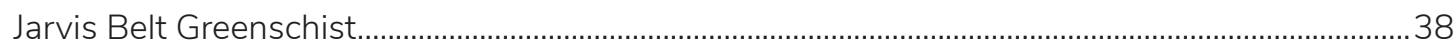

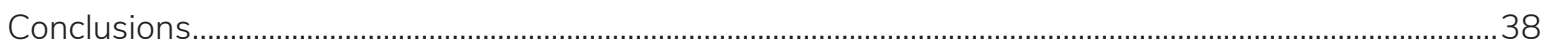

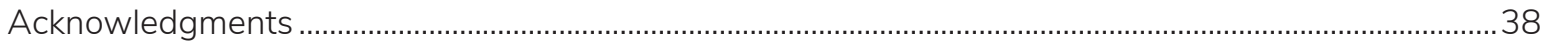

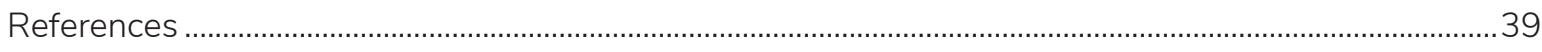

Chapter C: Regional correlation of Metamorphic Rocks in the Ladue River-Mount Fairplay

Map Area Using Trace-Element Geochemistry of metamafic rocks ...................................................... 40

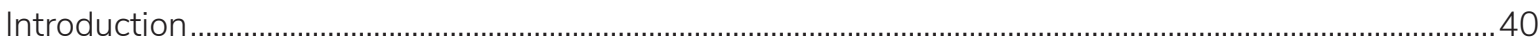

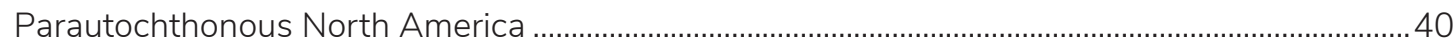

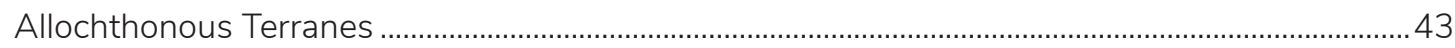

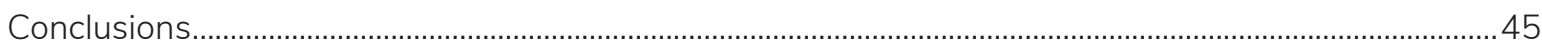

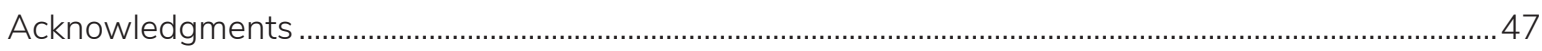

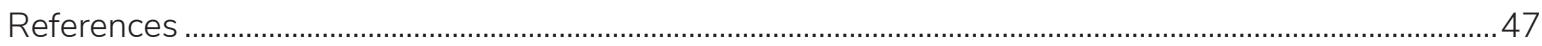

Chapter D: Structural Geology of the Mount Fairplay-Ladue River Area ............................................... 50

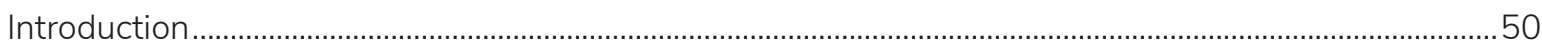

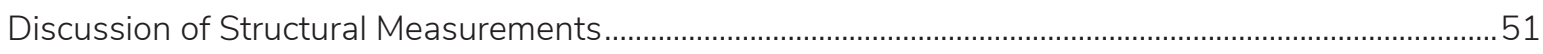

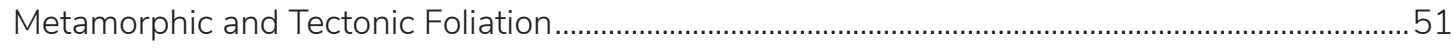

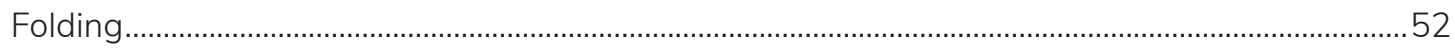




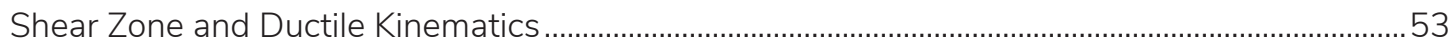

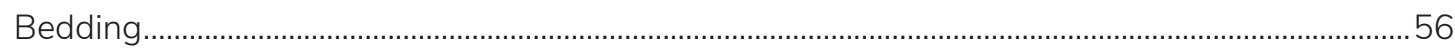

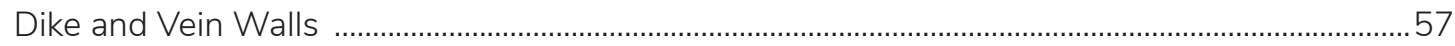

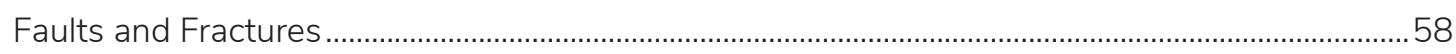

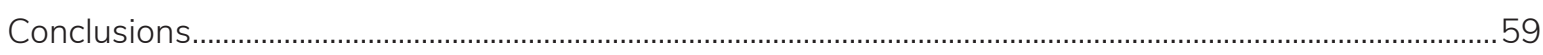

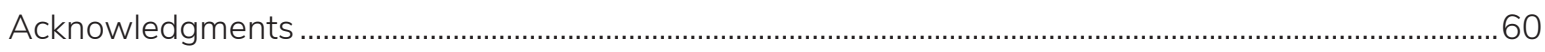

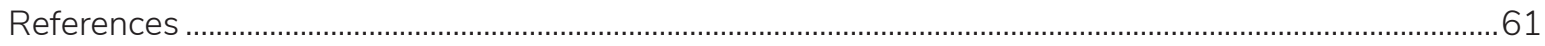

Chapter E: Geochemistry of the Igneous Rocks in the Ladue River-Mount Fairplay Area......................63

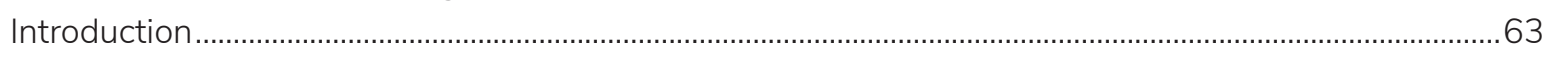

Paleogene Rhyolite and Felsic Porphyry........................................................................................................6

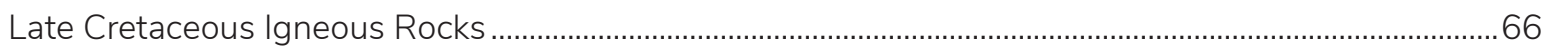

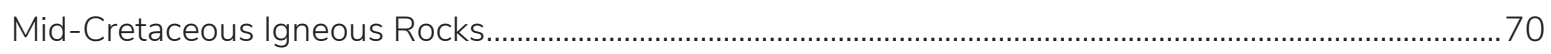

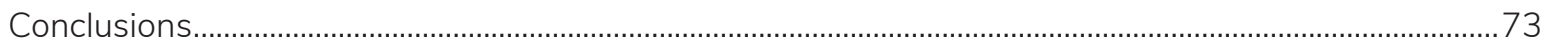

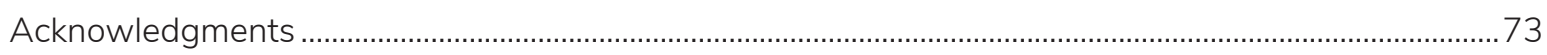

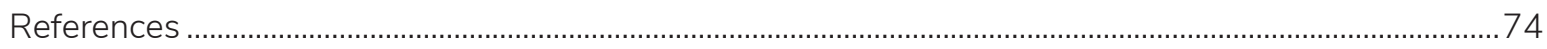

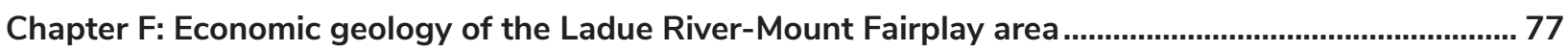

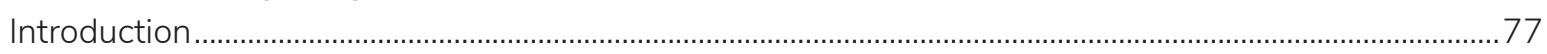

Stratabound Mineralization Hosted by Paleozoic Rocks...................................................................... 77

Ladue Prospect Group (Bjork, Ladue Camp) ..........................................................................................

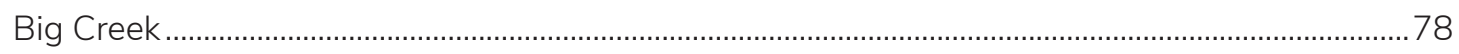

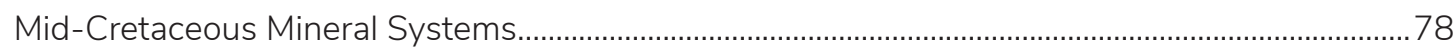

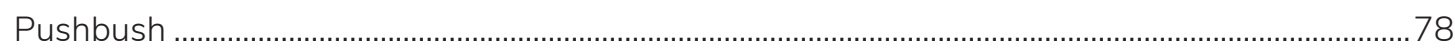

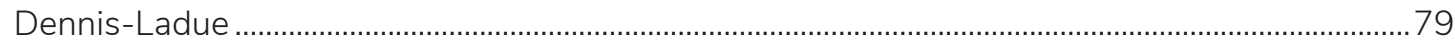

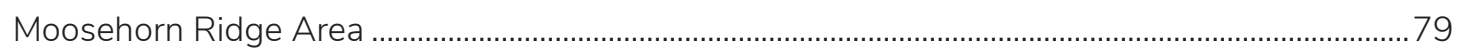

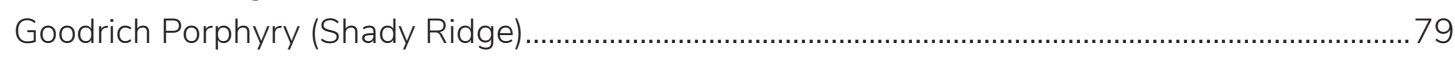

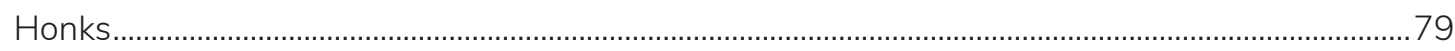

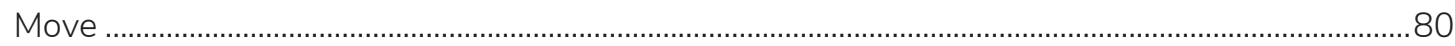

Late Cretaceous-Early Paleogene Mineral Systems …...............................................................................80

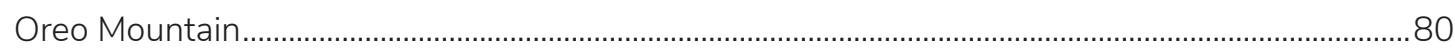

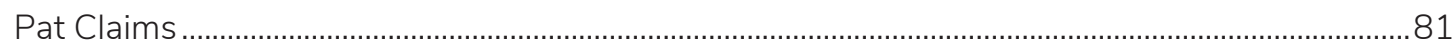

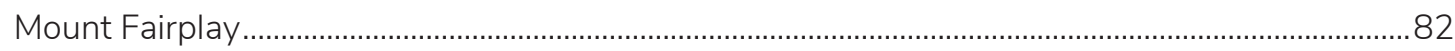

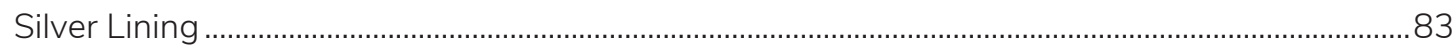

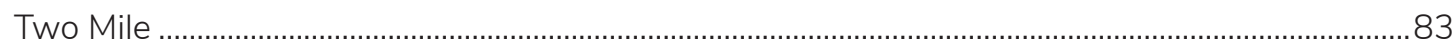

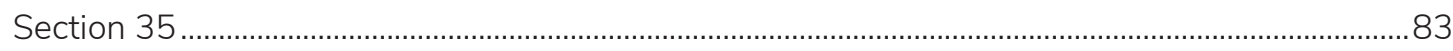

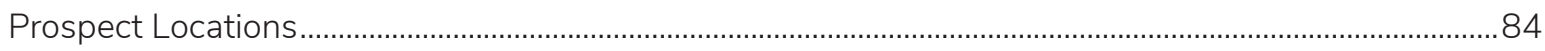

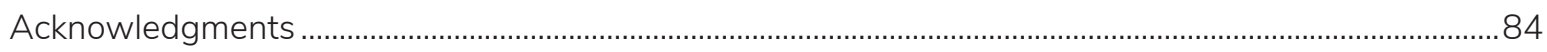

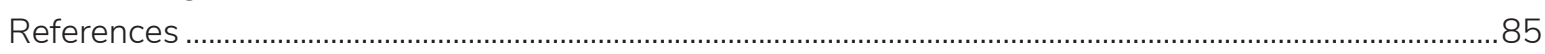




\section{CHAPTER A: BEDROCK GEOLOGIC MAP OF THE LADUE RIVER-MOUNT FAIRPLAY AREA, TANACROSS AND NABESNA QUADRANGLES, ALASKA}

Evan Twelker ${ }^{1}$, Rainer J. Newberry ${ }^{2}$, Alicja Wypych ${ }^{1}$, Travis J. Naibert ${ }^{1}$, Alec D. Wildland ${ }^{1}$, Karri R. Sicard ${ }^{1}$, Sean P. Regan ${ }^{2}$, Jennifer E. Athey ${ }^{1}$, W. Chris Wyatt ${ }^{1}$, and Julian A. Lopez ${ }^{3}$

\section{INTRODUCTION}

The Mineral Resources section of the Alaska Division of Geological \& Geophysical Surveys (DGGS) conducted bedrock geologic mapping of a 4,800-sq-km (1,860-sq-mi) area of eastern Interior Alaska including Mount Fairplay and the Ladue River drainage. The area lies north of the Alaska
Highway and is approximately $65 \mathrm{~km}$ (40 mi) east of Tok, Alaska; it runs west from the Alaska-Yukon border to encompass the Taylor Highway (fig. 1). DGGS and the U.S. Geological Survey (USGS) staff identified this area as having potential to host deposits of critical minerals, including rare earth elements (REE), uranium, niobium, zirconium,

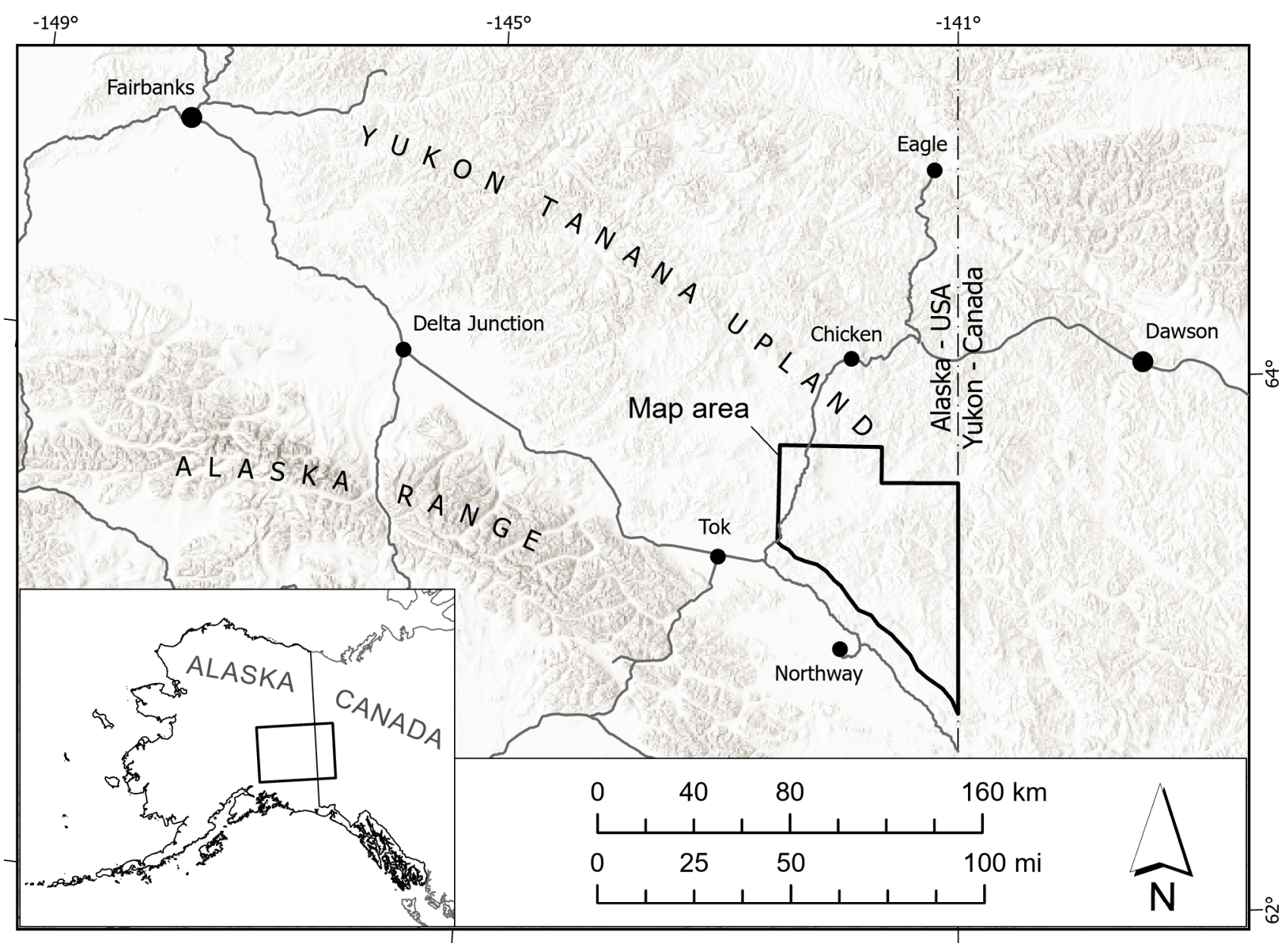

Figure 1. Map showing the geographic location of the map area.

\footnotetext{
${ }^{1}$ Alaska Division of Geological \& Geophysical Surveys, 3354 College Rd., Fairbanks, Alaska 99709-3707

2 Department of Geosciences, University of Alaska, P.O. Box 755780, Fairbanks, Alaska 99775-5780

${ }^{3}$ Colorado College, Department of Geology, 14 East Cache la Poudre St., Colorado Springs, CO 80903
} 
tin, tungsten, bismuth, and rhenium, as well as conventional mineral resources including gold, copper, molybdenum, lead, zinc, and silver. Most of the known mineralization in the area is related to Cretaceous-Paleogene magmatism, which spans a broad diversity of compositions and ranges in scale from batholiths to shallowly emplaced dikes to volcanic rocks. The igneous rocks intrude a composite metamorphic province that includes both parautochthonous North America and components of the allochthonous Yukon Tanana Terrane, now juxtaposed against one another by Jurassic-Cretaceous low-angle faults and subsequently disrupted by multiple generations of Cretaceous-Cenozoic high-angle faults (fig. 2).

This map and associated geologic report are the product of 315 person-days of helicopter-supported fieldwork completed by the authors during 2019, plus limited compilation of existing geologic maps of the area (Foster, 1967; Foster, 1970). The age assignments for igneous and metaigneous map units are supported by 37 new U-Pb zircon ages completed as part of this study (table 1; Wildland and others, 2021). Cooling ages of metamorphic rocks and hydrothermal alteration assemblages are informed by preliminary results from 24 new ${ }^{40} \mathrm{Ar} /{ }^{39} \mathrm{Ar}$ ages, which are in-process. Several detrital zircon analyses contributed to our understanding of the Cretaceous sedimentary rocks (table 2; Twelker and O'Sullivan, 2021b). All age uncertainties in this report are $2 \sigma$ (95 percent confidence level), and where original data sources reported $1 \sigma$ uncertainty we have converted it to $2 \sigma$. We used geochemical data, including 284 whole-rock analyses (Wypych and others, 2019) and more than 1,600 handheld X-ray fluorescence (XRF) analyses, to describe, classify, and map the distribution of different lithologic units on the map. In addition to our own data, this map is also built on an open exchange of data and ideas with our colleagues at the U.S. Geological Survey Alaska Science center, including zircon ages (Jones and O'Sullivan, 2020) and ${ }^{40} \mathrm{Ar} /{ }^{39} \mathrm{Ar}$ ages (Jones and Benowitz, 2020).
The map area lies in the Yukon-Tanana Upland (Wahrhaftig, 1960) and is characterized by moderate-relief, thickly vegetated hills and minimal outcrop; glacial deposits were not observed and eolian deposits are generally thin. Our map interpretation relies on observations of outcrop, subcrop, and float, and we make extensive use of airborne magnetic (Emond and others, 2015) and magnetic-electromagnetic surveys (Burns and others, 2020a,b) for interpolation between field stations. Our mapping of high-angle faults relies on tilt-derivative processing of aeromagnetic data, low resistivity anomalies in electromagnetic surveys, photo and topographic lineaments, and lithologic discontinuities between ridges.

This report includes the following chapters emphasizing different aspects of the geology of the study area:

- Chapter A: Introduction and description of map units

- Chapter B: Metamorphism of the Ladue River-Mount Fairplay area

- Chapter C: Regional correlation of metamorphic rocks in the Ladue River-Mount Fairplay map area using trace-element geochemistry

- Chapter D: Structural geology of the Mount Fairplay-Ladue River area

- Chapter E: Geochemistry of select igneous rocks of the Ladue River-Mount Fairplay area

- Chapter F: Economic geology of the Ladue River-Mount Fairplay area

\section{REGIONAL GEOLOGY}

The Ladue River-Mount Fairplay map area includes the structurally complex boundary between the allochthonous Yukon Tanana Terrane (YTT) and the parautochthonous North American margin (pNA; fig. 2). The YTT includes a series of late Paleozoic volcanic arcs and related intrusive rocks on basement rifted from the western margin of North America (Laurentia) during the Late Devonian-Early Mississippian (Dusel-Bacon and 


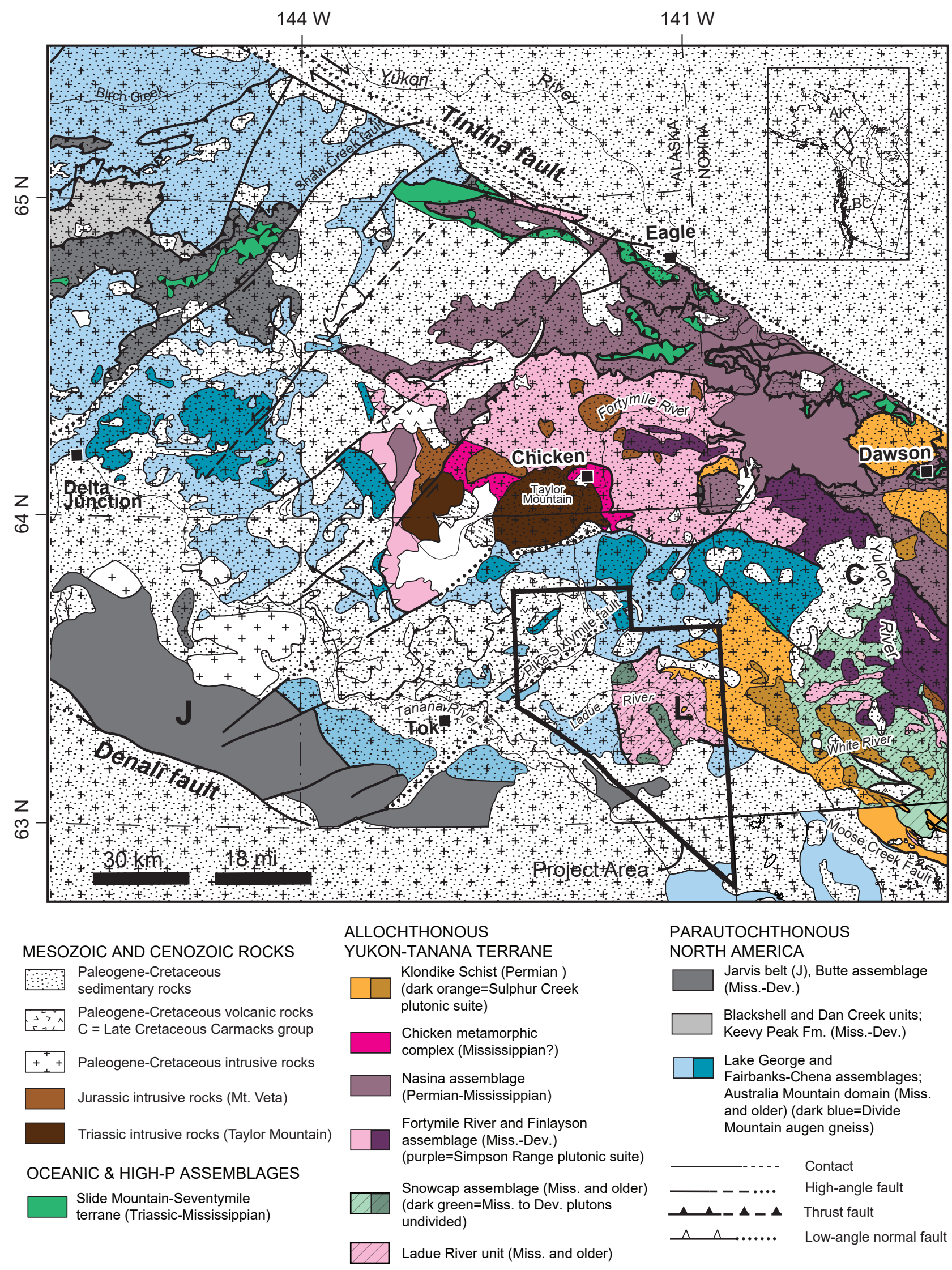

Figure 2. Generalized regional geologic map, adapted from Dusel-Bacon and others (2017; with modifications by James V. Jones III, USGS). "C" indicates Late Cretaceous Carmacks Group volcanic rocks; "L" indicates the Ladue River unit; "J" indicates Jarvis belt. 
Table 1. Selected U-Pb zircon age analyses used in the construction of this map. References: (1) LA-ICP-MS ages reported in Wildland and others (2021); (2) SHRIMP ages reported in Dusel-Bacon and others (2015); (3) TIMS age reported in Dusel-Bacon and others (2006); (4) Jones and O'Sullivan (2020).

\begin{tabular}{|c|c|c|c|c|c|c|c|c|}
\hline Sample & $\begin{array}{l}\text { Map } \\
\text { unit }\end{array}$ & Lithology & Latitude & Longitude & $\begin{array}{l}\text { Weighted } \\
\text { mean age }\end{array}$ & $\begin{array}{l}\text { Uncertainty } \\
\text { (2 sigma) }\end{array}$ & MSWD & Ref. \\
\hline $19 K S 100$ & Pefp & granite porphyry & 63.5197 & -141.3235 & 57.1 & 1.2 & 1.5 & 1 \\
\hline $19 \mathrm{ET} 277$ & Pefp & rhyolite & 63.3828 & -141.8030 & 58.6 & 1.4 & 1.0 & 1 \\
\hline 19AW256 & $\mathrm{Per}$ & rhyolite & 63.4673 & -142.4666 & 58.9 & 1.4 & 1.0 & 1 \\
\hline 08ADb13 & IKgqm & quartz monzonite & 63.6547 & -142.2903 & 66.5 & 1.1 & - & 2 \\
\hline 08ADb14 & IKsy & syenite & 63.6819 & -141.2581 & 67.0 & 1.5 & - & 2 \\
\hline 19RN287 & IKpg & porphyritic granite & 63.3791 & -141.8164 & 68.8 & 1.5 & 0.9 & 1 \\
\hline 19WCW037 & IKgd & granodiorite & 63.5726 & -141.4382 & 69.3 & 1.4 & 1.3 & 1 \\
\hline 19RN359 & $\mathrm{IKfd}$ & felsic dike & 63.6871 & -142.2587 & 70.5 & 1.6 & 1.9 & 1 \\
\hline 19TJN243 & $\mathrm{IKgd}$ & granodiorite & 63.3848 & -141.8155 & 71.4 & 1.4 & 2.1 & 1 \\
\hline 19RN282 & $\mathrm{IKgd}$ & granodiorite & 63.3836 & -141.8037 & 72.1 & 1.6 & 1.1 & 1 \\
\hline 19ADW053 & Kmd & monzonite & 63.2340 & -141.2208 & 100.3 & 2.2 & 3.3 & 1 \\
\hline 19ADW016 & Kmi & felsic dike & 63.0578 & -141.0771 & 102.8 & 2.2 & 3.3 & 1 \\
\hline 19ET054 & Kgd & granodiorite & 63.1975 & -141.0479 & 104.2 & 2.3 & 1.7 & 1 \\
\hline 19ET288 & $\mathrm{Kg}$ & granite & 63.3617 & -141.8630 & 106.7 & 2.3 & 1.6 & 1 \\
\hline 19AW200 & Kgp & granite porphyry & 63.3948 & -142.3554 & 107.2 & 2.4 & 2.5 & 1 \\
\hline 19JEA029 & Kgd & granodiorite & 63.2619 & -141.1235 & 107.7 & 2.3 & 1.3 & 1 \\
\hline $19 \mathrm{ET} 146$ & $\mathrm{Kg}$ & granite & 63.4919 & -141.6891 & 107.9 & 2.4 & 0.9 & 1 \\
\hline 19TJN299 & Kwff & felsic tuff & 63.7295 & -142.3061 & 107.9 & 2.2 & 1.3 & 1 \\
\hline 19SPR027 & Kgb & diorite & 63.3172 & -142.1020 & 108.1 & 2.3 & 2.7 & 1 \\
\hline 19WCW039 & $\mathrm{Kg}$ & granite & 63.5658 & -141.4154 & 109.1 & 2.2 & 12.0 & 1 \\
\hline 19RN222 & Kgp & granite porphyry & 63.3957 & -142.1532 & 109.2 & 2.4 & 1.5 & 1 \\
\hline 19TJN181 & $\mathrm{Kg}$ & granite & 63.3958 & -142.1536 & 109.7 & 2.2 & 2.9 & 1 \\
\hline 19ET102 & Kmi & porphyry dike & 63.5203 & -141.3252 & 110.7 & 2.5 & 1.2 & 1 \\
\hline 19TJN231 & Kgp & granite porphyry & 63.5260 & -142.3200 & 111.8 & 2.2 & 2.0 & 1 \\
\hline 19RN423 & $\mathrm{Kg}$ & granite & 63.7192 & -141.8181 & 112.8 & 2.6 & 2.6 & 1 \\
\hline 19SPR102 & Kgp & granite porphyry & 63.6166 & -142.2189 & 115.0 & 2.5 & 4.0 & 1 \\
\hline 19ET098 & Pks & schist & 63.5173 & -141.1760 & 256.7 & 5.8 & 1.0 & 1 \\
\hline $19 \mathrm{ET} 126$ & Pks & schist & 63.3351 & -141.0576 & 261.4 & 5.8 & 0.9 & 1 \\
\hline 16AJJ219D & Pks & schist & 63.4611 & -141.2739 & 267.0 & 3.7 & 2.4 & 4 \\
\hline 16AJJ275B & MDpo & augen orthogneiss & 63.3446 & -141.3502 & 352.1 & 7.1 & 1.8 & 4 \\
\hline 14AJJ019 & $\mathrm{MDg}$ & metagranitoid & 63.3040 & -141.4625 & 354.5 & 2.7 & 1.5 & 4 \\
\hline 16AJJ250A & MDpo & orthogneiss & 63.4557 & -141.3745 & 355.5 & 11.5 & 1.16 & 4 \\
\hline 14AJJ016 & MDpo & orthogneiss & 63.3104 & -141.4639 & 356.7 & 4.1 & - & 4 \\
\hline 19WCW048 & MDpo & orthogneiss & 63.2706 & -141.2756 & 359.7 & 7.2 & 2.3 & 1 \\
\hline 19ADW351C & MDag & granite orthogneiss & 63.6588 & -141.7359 & 360.7 & 8.7 & 0.8 & 1 \\
\hline 19ET045 & $\mathrm{MDg}$ & metagranitoid & 63.2652 & -141.1283 & 360.7 & 7.8 & 4.0 & 1 \\
\hline 19ET158 & $\mathrm{MDa}$ & amphibolite & 63.3207 & -141.6333 & 361.8 & 7.4 & 1.6 & 1 \\
\hline 00ADb59 & MDg & schist & 63.478 & -141.604 & 362.9 & 1.4 & - & 3 \\
\hline 19AW285 & $\mathrm{MDg}$ & metagranitoid & 63.3916 & -141.9208 & 363.0 & 7.9 & 1.7 & 1 \\
\hline 14AJJ025 & MDg & orthogneiss & 63.2915 & -141.4343 & 363.4 & 5.2 & 2.1 & 4 \\
\hline 19WCW067 & $\mathrm{MDg}$ & metagranitoid & 63.2584 & -141.6044 & 364.9 & 7.3 & 1.7 & 1 \\
\hline 14AJJ013 & $\mathrm{MDg}$ & orthogneiss & 63.2199 & -141.3789 & 365.0 & 3.3 & 1.2 & 4 \\
\hline 16AJJ211 & $\mathrm{MDg}$ & metagranitoid & 63.3438 & -141.3678 & 365.1 & 5.1 & 1.4 & 4 \\
\hline 19ET034 & MDmr & metarhyolite & 63.0598 & -141.4573 & 366.8 & 8.1 & 2.2 & 1 \\
\hline 19SPR174 & MDag & granite & 63.6587 & -141.7359 & 367.6 & 8.4 & 5.8 & 1 \\
\hline 17AJJ108 & $\mathrm{MDg}$ & metagranitoid & 63.2609 & -141.3951 & 368.3 & 4.9 & 1.8 & 4 \\
\hline 19RN278 & $\mathrm{MDg}$ & metagranitoid & 63.4027 & -141.7008 & 370.1 & 8.4 & 0.9 & 1 \\
\hline 19ADW202 & MDlo & leucogranite & 63.2561 & -141.8652 & 370.6 & 8.3 & 2.7 & 1 \\
\hline 19SPR004 & $\mathrm{MDg}$ & metagranitoid & 63.4218 & -142.2953 & 375.7 & 9.0 & 1.1 & 1 \\
\hline
\end{tabular}


Table 2. Sample locations and youngest statistical population (YSP) maximum depositional ages (MDAs) for the detrital zircon samples used in construction of this map. MDAs for all samples are reported in Twelker and O'Sullivan (2021b); the original data for 19 KS149 is from Jones and O'Sullivan (2020).

\begin{tabular}{cccccccc} 
Sample & $\begin{array}{c}\text { Latitude } \\
\text { (WGS84) }\end{array}$ & $\begin{array}{c}\text { Longitude } \\
\text { (WGS84) }\end{array}$ & Map unit & $\begin{array}{c}\text { Lithology } \\
\text { 19ET330 }\end{array}$ & $\begin{array}{c}\text { YSP (Ma) } \\
\mathbf{\pm} \mathbf{2} \sigma\end{array}$ & MSWD & $\begin{array}{c}\text { n (YSP) / } \\
\text { n sample }\end{array}$ \\
\hline 19KS430 & 63.6982 & -141.7433 & IKav & $\begin{array}{c}\text { Volcaniclastic } \\
\text { conglomerate }\end{array}$ & $65.8 \pm 1.9$ & 1.05 & $12 / 110$ \\
\hline 19AW206 & 63.3867 & -142.3942 & GKs & Conglomerate & $103.2 \pm 2.2$ & 0.99 & $20 / 110$ \\
\hline $19 K S 149$ & 63.3912 & -141.1216 & GrKs & Conglomerate & $54.0 \pm 1.1$ & 1.00 & $70 / 110$ \\
\hline
\end{tabular}

others, 2006, and references therein). The YTT was then accreted to North America during the Mesozoic (Dusel-Bacon and others, 2002; Dusel-Bacon and others, 2015). Extensive mid-Cretaceous magmatism affected both the YTT and pNA, indicating YTT accretion occurred prior to that time. Low-angle ductile extensional shear zones were also developed between the YTT and pNA assemblages in the mid-Cretaceous (Hansen and others, 1991; Pavlis and others, 1993; Dusel-Bacon and others, 2002). Additional periods of magmatism during the Late Cretaceous and Early Paleogene are recorded by both volcanic and intrusive units in the map area (Foster, 1970; Bacon and others, 1990; Solie and others, 2014). Finally, the area was extensively modified by Cenozoic high-angle faults, resulting in the current complex exposure of the YTT-parautochthon boundary (Sánchez and others, 2014; Solie and others, 2019; Wypych and others, 2021).

\section{Parautochthonous North American Assemblages}

The rocks of pNA include metamorphosed siliciclastic sedimentary rocks thought to have been deposited along the continental margin of Laurentia, including the Lake George assemblage, Divide Mountain augen gneiss, and Jarvis belt (discussed below). Detrital zircon data from pNA units indicate derivation from Archean to Proterozoic source rocks (Dusel-Bacon and others,
2017). The pNA units in Alaska are thought to be the metamorphosed equivalent of Paleozoic to Neoproterozoic continental margin rocks of the Selwyn Basin in Yukon (Mair and others, 2006). Sedimentary protoliths are interlayered with, or intruded by, Late Devonian to Early Mississippian felsic and mafic metaigneous rocks.

Parautochthonous North American rocks in eastern Alaska are characterized by subhorizontal-dominant foliations, which are at least the second generation of foliation in most locations. An older foliation that is folded into tight isoclinal folds is observed at many localities. Mid-Cretaceous ${ }^{40} \mathrm{Ar} /{ }^{39} \mathrm{Ar}$ cooling ages in pNA are characteristic, in contrast to Jurassic to Permian ${ }^{40} \mathrm{Ar} /{ }^{39} \mathrm{Ar}$ cooling ages in the YTT (Dusel-Bacon and others, 2002; Naibert and others, 2020; Jones and Benowitz, 2020). The pNA units are intruded by Late Devonian-Early Mississippian intrusions, metamorphosed to orthogneiss, and by Cretaceous to Paleogene intrusions as old as approximately 114 Ma (for example, Dusel-Bacon and others, 2015; Solie and others, 2014; Wypych and others, 2020; Jones and O'Sullivan, 2020). Permian to Jurassic intrusions that are common in the YTT are absent from the pNA units.

\section{Lake George Assemblage}

The Lake George assemblage extends north of the Tanana River in eastern Alaska from the Yukon border to the Salcha River area (Dusel-Bacon and 
others, 2006). The assemblage is a mix of amphibolite-facies quartzite, paragneiss, and quartzose schists, along with interlayered amphibolites and abundant Late Devonian-Early Mississippian orthogneiss bodies. Orthogneiss bodies within the Lake George assemblage have dioritic to granitic composition and are fine- to medium-grained. Intrusive contacts are often poorly exposed but are generally concordant with foliation. In the northeastern Tanacross quadrangle, the orthogneiss layers are interpreted to have been intruded as dikes, sills, and small plutons with thicknesses from $30 \mathrm{~cm}$ to $300 \mathrm{~m}$ (Wypych and others, 2021), which were metamorphosed and deformed with their host rocks. Zircon $\mathrm{U}-\mathrm{Pb}$ ages from orthogneiss samples in the eastern Tanacross Quadrangle are Late Devonian (ca. 371-376 Ma; Jones and O'Sullivan, 2020; Todd and others, 2019).

\section{Divide Mountain Augen Gneiss}

The Divide Mountain augen gneiss is a suite of megacrystic granitoid plutons metamorphosed to amphibolite-facies augen orthogneiss (DuselBacon and Aleinikoff, 1996; Dusel-Bacon and Williams, 2009) like the bodies of augen gneiss initially described by Dusel-Bacon and Aleinikoff (1985). This unit was previously included in the Lake George assemblage (Dusel-Bacon and others, 2006) and was first divided into a subunit in the northeastern Tanacross quadrangle by Wypych and others (2021). We separate the Divide Mountain augen gneiss in our map area and throughout the Yukon-Tanana Upland from the mostly metasedimentary and metavolcanic Lake George assemblage as a Late Devonian-Early Mississippian intrusive suite because of observed crosscutting contacts with the Lake George assemblage, as well as to match the practice of dividing intrusive suites and host rocks into different units as practiced in Yukon (for examples see Yukon Geological Survey, 2019). Pluton contacts are observed to be both crosscutting and interlayered within the Lake George assemblage, and the augen gneiss is interpreted to have been metamorphosed and deformed with the Lake George assemblage. Zircon U-Pb ages in the region range from ca. 371 to $347 \mathrm{Ma}$ (DuselBacon and others, 2006; Todd and others, 2019; Jones and O'Sullivan, 2020; Wildland and others, 2021). In the Tok River area, augen gneiss intrudes the Macomb belt (Sicard and others, 2017), which is a possible correlative of the Lake George assemblage in the Alaska Range (Dusel-Bacon and others, 2006). Similar augen orthogneiss has been documented throughout the eastern Yukon Tanana Upland, mostly to the east of the northeast-striking Shaw Creek fault (fig. 2).

\section{Jarvis Belt}

The Jarvis belt is a mixed unit of felsic metavolcanic, metavolcaniclastic, and siliciclastic rocks, which are mostly metamorphosed to greenschist-facies, though samples from the Ladue RiverMount Fairplay map area include relict amphibolite-facies mineralogy. The Jarvis belt is extensively exposed in the Tok River area (Sicard and others, 2017), along the Alaska Highway (Solie and others, 2019), and the Delta mineral belt (Dashevsky and others, 2003), where it is further subdivided by lithology. Metavolcanic rocks from the Jarvis belt have Mississippian-Devonian U-Pb zircon ages, which suggests that the unit may represent a volcanic arc of that age that is stratigraphically and (or) structurally above the Lake George assemblage and the Divide Mountain augen gneiss intrusions of similar age (Nokleberg and Aleinikoff, 1985; Dashevsky and others, 2003). However, unlike the Lake George assemblage, the Jarvis belt is intruded by Triassic (?) gabbro sills, which are parallel or subparallel to foliation and lithologic contacts.

A possible correlative of the Jarvis belt is the White River assemblage in western Yukon. The White River assemblage includes the basal Scottie Creek formation and the overlying White River Complex, and intrusions of the Devonian Mount Baker plutonic suite (Ryan and others, 2013, 2014). The Scottie Creek formation is dominantly quartzite and muscovite schist well as quartzofeldspathic schist (Ryan and others, 2014). The White River Complex includes Late Devonian metavolcanic rocks and minor carbona- 
ceous schist. Metavolcanic protolith ages from the White River assemblage, as well as similar lithologies, suggest a correlation to the Jarvis belt rocks in the Tok River area. The ca. 375 Ma Mount Baker plutonic suite may be correlative with the fine-to medium-grained orthogneiss within the Lake George assemblage (Ryan and others, 2014). The White River assemblage is also intruded by Triassic gabbro and diabase of the Snag Creek suite (Ryan and others, 2014), which are similar to the gabbro sills in the Jarvis belt of the Tok River area (Sicard and others, 2017), the Alaska Highway corridor (Solie and others, 2019), and the Delta mineral belt (Dashevsky and others, 2003).

\section{Yukon Tanana Terrane Assemblages}

The complexly deformed Yukon Tanana Terrane is generally interpreted as a series of Mississippian to Permian volcanic arcs developed on a basement of pre-Devonian metasedimentary continental margin rocks rifted from North America during the Late Devonian to Early Mississippian (Colpron and others, 2006). Regional units of the YTT include the Snowcap, Finlayson, Fortymile River, Nasina, and Klondike assemblages. The YTT within the area is known as the Ladue River unit (Dusel-Bacon and others, 2006) and it has an incompletely resolved relationship to these regional units (see discussion below and in chapters B and C). The metamorphic assemblages of the YTT are polydeformed and likely experienced multiple periods of metamorphism. Jurassic-Triassic plutons intrude the YTT, including the Taylor Mountain batholith and surrounding plutons (Werdon and others, 2001), the Mount Veta batholith (Dusel-Bacon and others, 2013), and the Aishihik plutonic suite in Yukon (Ryan and others, 2013), and do not intrude the parautochthonous units, indicating collision and thrust faulting of the YTT over pNA did not occur until the Early Jurassic. Fortymile River and Finlayson assemblage ${ }^{40} \mathrm{Ar} /{ }^{39} \mathrm{Ar}$ cooling ages are mostly Early Jurassic (Dusel-Bacon and others, 2002; Naibert and others, 2020; Jones and Benowitz, 2020; Yukon Geological Survey, 2019), which record the timing of erosional exhumation during collision and thrust faulting of YTT over pNA. Cooling ages in the Klondike assemblage and parts of the Ladue River unit are Permian to Triassic, indicating that these units may have been structurally higher and had already exhumed through the argon closure temperatures of muscovite and biotite prior to Early Jurassic collision (Jones and Benowitz, 2020).

\section{Snowcap and Finlayson Assemblages}

The metasedimentary basement rocks of YTT are mapped in Yukon as the Snowcap assemblage and presented here as a possible regional correlation for rocks of the Ladue River unit. The interpretation of the Snowcap assemblage as a rifted part of the North American continental margin is supported by lithologies broadly equivalent to the Lake George assemblage in pNA and pre-Devonian detrital zircon populations similar to continental margin rocks (Nelson and others, 2006, Piercey and Colpron, 2009). The geochemistry of Snowcap amphibolites, enriched mid-ocean ridge basalt (E-MORB) and ocean-island basalt (OIB), is most likely related to one of several Neoproterozoic to early Paleozoic continental rifting events that affect the Laurentian margin (Piercey and Colpron, 2009). The Snowcap assemblage is commonly intruded by the Early Mississippian Simpson Range plutonic suite and, locally, by the Late Devonian Grass Lakes plutonic suite (Colpron and others, 2006). The unit is also intruded by orthogneiss of the Permian Sulphur Creek plutonic suite, which is interpreted as the roots of the Klondike assemblage volcanic arc (discussed below). A 365 Ma detrital zircon population in the Stevenson Ridge area in western Yukon adjacent to our map area suggests continued sediment deposition following or coeval with Devonian pluton emplacement (Ryan and others, 2014) and Lower Mississippian felsic metavolcanic rocks in the upper part of the correlative Dorsey Complex in southern Yukon suggest at least local transition into the overlying Finlayson assemblage (Colpron and others, 2006).

Widespread Upper Devonian to Lower Mississippian bimodal metavolcanic rocks in Yukon are assigned to the Finlayson assemblage and represent 
both arc and back-arc magmatism (Colpron and others, 2006) following rifting of YTT from North America. The Finlayson assemblage also includes related volcaniclastic metasedimentary rocks, recycled siliciclastic rocks, and locally thick marble layers. In the Stevenson Ridge area, Yukon, the Finlayson assemblage includes massive amphibolite layers interpreted as mafic flows or sills, which are locally in structural contact with Snowcap assemblage rocks (Ryan and others, 2014).

Two Late Devonian to Mississippian plutonic suites intrude the Snowcap and Finlayson assemblages in Yukon: The Grass Lakes and the Simpson Range plutonic suites. Both plutonic suites are metamorphosed and deformed to orthogneiss of varying textures. The Grass Lakes plutonic suite was intruded into the Snowcap assemblage and the lower parts of the Finlayson assemblage in the eastern Finlayson Lake district during the Late Devonian and earliest Mississippian (Colpron and others, 2006; Piercey and others, 2006). The Grass Lakes plutonic suite is interpreted by Piercey and others (2006) to represent within-plate magmatism in a back-arc setting. Grain size varies considerably within the Grass Lakes suite, including large feldspar porphyroclasts in some localities. The Early Mississippian Simpson Range plutonic suite intrudes the Snowcap assemblage and the Finlayson assemblage in Yukon. The Simpson Range plutons are the primary record of arc magmatism in the Finlayson assemblage in the Finlayson Lakes district and in the Stewart River area (Piercey and others, 2006), and have tonalitic-dioritic-granodioritic compositions.

\section{Fortymile River Assemblage}

The Fortymile River assemblage in eastern Alaska is correlative with the Finlayson assemblage and is exposed in the northeast Tanacross Quadrangle (Wypych and others, 2021) and adjacent parts of the Eagle Quadrangle (Werdon and others, 2001, Szumigala and others, 2002); it is presented here for purposes of comparison to the Ladue River unit of this map. The Fortymile River assemblage includes interlayered orthogneiss, paragneiss, quartz schist, and locally thick marble layers. Interlayered amphibolites up to 10's of meters thick are also common. The abundance of granodiorite-tonalite composition orthogneiss bodies within the Fortymile River assemblage matches the description of voluminous orthogneiss of the Simpson Range plutonic suite within the Finlayson assemblage in the Stewart River area across the Yukon-Alaska border (Colpron and others, 2006). The dominance of orthogneiss in these areas was interpreted by Colpron and others (2006) as a more deeply exhumed part of the Finlayson assemblage volcanic arc system.

\section{Klondike Assemblage}

The Klondike assemblage in the Stewart River, Stevenson Ridge, and Dawson areas in Yukon consists of Middle to Late Permian metavolcanic rocks and interbedded metasedimentary rocks (Colpron and others, 2006). Greenschist-facies felsic metavolcanic rocks define the Klondike schist in the Stewart River and Stevenson Ridge areas, which also includes minor mafic metavolcanic rocks (Gordey and Ryan, 2005; Ryan and others, 2014). The Klondike schist metavolcanic rocks are generally interpreted as a volcanic arc. The Sulphur Creek plutonic suite represents the magmatic roots of the Klondike schist and shares the same composition and Permian ages (ca. 262 to $257 \mathrm{Ma}$ ) (Beranek and Mortenson, 2011; Ryan and others, 2014). Sulphur Creek plutons intrude the Klondike schist as well as the underlying Snowcap and Finlayson assemblages over a large area in western Yukon (Milidragovic and others, 2016).

\section{Ladue River Unit}

The Ladue River unit, initially defined by Dusel-Bacon and others (2006), is a subregional unit with incompletely understood relationships to the previously described regional units of the YTT. The unit was first mapped by Foster (1970), who recognized a body of mostly greenschist-facies schist and suggested a correlation to the Klondike schist of Cockfield (1921) in the adjacent Yukon. Dusel-Bacon and others (2006) described a mix of sedimentary, volcanic, and granitic protoliths 
and characterized the unit as upper greenschist to lower amphibolite-facies rocks variably retrograded to greenschist facies. A schistose metaigneous rock (00ADb59; table 1) yielded a Late Devonian $\mathrm{U}-\mathrm{Pb}$ zircon age, precluding a simple correlation of this unit to the Permian Klondike assemblage (Dusel-Bacon and others, 2006). Further U-Pb and ${ }^{40} \mathrm{Ar} /{ }^{39} \mathrm{Ar}$ geochronology by the USGS led to the recognition that the original Ladue River unit includes both Permian rocks and Mississippian or older rocks of less certain regional correlation (Jones and others, 2017). In our map and report, the Permian rocks have been removed from the Ladue River unit and assigned to the Klondike assemblage units (Pks, Pkmb, Pkgs). The Mississippian and older units (MDg, MDpo, MDa, MPms) may be correlated to the Fortymile River assemblage, the Snowcap assemblage, or both. Our observations, presented with the unit descriptions and in chapters $B$ and $C$, suggest a partial similarity to the Fortymile River assemblage. However, we also observe that the Ladue River unit lacks Triassic and Jurassic intrusions found in the Fortymile River assemblage and may have older ${ }^{40} \mathrm{Ar} /{ }^{39} \mathrm{Ar}$ cooling ages than the Fortymile River or Snowcap assemblages (Jones and Benowitz, 2020).

\section{Seventymile Terrane}

The Seventymile terrane in eastern Alaska is a widespread series of fault-bound slices of variably serpentinized harzburgite and dunite, weakly metamorphosed mafic volcanic rocks and gabbros, and Mississippian to Upper Triassic chert and other marine sedimentary rocks (Dusel-Bacon and others, 2006). The Seventymile terrane is considered to be equivalent to the Slide Mountain assemblage in Yukon and British Columbia (Colpron and others, 2006). The Slide Mountain assemblage in Yukon is well exposed in the Finlayson Lake district, where it includes weakly metamorphosed Permian basalts of the Campbell Range formation (Colpron and others, 2006). The Seventymile terrane is generally interpreted as a dismembered ophiolite sequence (Keith and others, 1981; Foster and others, 1994). Large fault slices of the Seventymile terrane are mapped in the Salcha River, Mount Sorenson, and American Creek areas in Alaska, and Clinton Creek in Yukon, and smaller serpentinized bodies occur throughout eastern Alaska and western Yukon (Dusel-Bacon and others, 2006). The smaller occurrences often have slip-fiber serpentine or other alteration that indicate slip-along contacts. The Seventymile terrane and Slide Mountain assemblages are interpreted as slices of oceanic crust obducted onto the YTT and North American margin during collision and their presence as thrust slices may indicate the location of major terrane boundaries (Colpron and others, 2006; Dusel-Bacon and others, 2006; Nelson and others, 2006).

\section{Mesozoic to Cenozoic Magmatism}

Mesozoic to Cenozoic magmatism in the region surrounding the study area spans from Triassic through to the Quaternary. The earliest Mesozoic magmatic rocks in the region include the Taylor Mountain Batholith and nearby intrusions (Werdon and others, 2001; Dusel-Bacon and others, 2015; Wypych and others, 2021), and the Early Jurassic plutonic rocks including the Mount Veta pluton (Dusel-Bacon and others, 2013); these units represent two pulses of arc magmatism above an east-dipping subduction zone (Dusel-Bacon and others, 2002; Dusel-Bacon and others, 2015). The Triassic and Jurassic intrusions are restricted to the allochthonous YTT in the Eagle and northeast Tanacross quadrangles; we did not observe magmatic rocks of these ages in the YTT units present in our study area.

The region experienced a magmatic lull during the period 179-115 Ma, followed by renewed magmatism ca. 115-98 Ma above a northeast-dipping subduction zone (Allan and others, 2013). Rocks of this age intrude primarily pNA and to a lesser extent YTT, indicating that the two terranes were proximal to each other by this time, if not finally sutured following mid-Cretaceous extensional faulting. They include batholith-scale intrusions, including the Dawson Range batholith, Yukon (Hart and others, 2004), granite porphyry dikes, and 
thick felsic volcanic deposits, interpreted as remnant calderas, at several locations in the Tanacross Quadrangle (Bacon and others, 1990). The wide range of depths of exposure reflects the differential uplift that has affected the area since the mid-Cretaceous.

Magmatic quiescence in the region corresponds to deposition of a Late Cretaceous continental sedimentary succession, the Indian River Formation in Yukon (Lowey and Hills, 1988). Arc magmatism resumed in the Late Cretaceous, expressed as relatively small intrusions including the Casino plutonic suite (ca. 79-72 Ma) and intrusions at the Taurus prospect area in the northeastern Tanacross Quadrangle (ca. 72-67 Ma; Allan and others, 2013; Kreiner and others, 2019; Wypych and others, 2020). This phase of magmatism hosts porphyry copper-molybdenum-gold mineralization at the Casino and Taurus deposits, among others (Allan and others, 2013). Younger, latest-Cretaceous (ca. 70-66 Ma) magmatism includes alkaline as well as calc-alkaline volcanic rocks of the Carmacks Group in Yukon (Allan and others, 2013) and the Middle Fork caldera in the southwestern Eagle Quadrangle (Bacon and others, 2014). The alkaline rocks of the Mount Fairplay complex were emplaced at this time, as were the intermediate, calc-alkaline volcanic rocks of the Tanacross D-1 Quadrangle (Wypych and others, 2021).

The last significant phase of magmatism in the eastern Yukon-Tanana Upland occurred during the Paleocene to Eocene (ca. 60-55 Ma). This phase includes mainly felsic (and locally mafic) dikes, plugs, and volcaniclastic rocks known as the Rhyolite Creek complex, as well as the Ruby Range plutonic suite in western Yukon (Allan and others, 2013). Scattered, volumetrically minor bimodal (mafic and felsic) volcanic and intrusive rocks are a broadly distributed throughout the Yukon-Tanana Upland (for example, Newberry and others, 1996; Werdon and others, 2001, Dilworth, 2003, Twelker and O'Sullivan, 2021a). The geochemistry of these rocks (see chapter $\mathrm{E}$ ) suggests they originated in an extensional environment (Flanigan and others, 2000), possibly related to motion along the Tintina fault and related structures (Allan and others, 2013).

\section{Mesozoic and Cenozoic Faults}

The YTT was internally imbricated and thrust over pNA and the Selwyn Basin by the Early to Middle Jurassic. The Seventymile/Slide Mountain terrane defines the suture zone between YTT and North America along much of the terrane boundary and is thought to represent the intervening ocean basin that closed prior to YTT accretion (Colpron and others, 2006). Thrust faults within the YTT and the Slide Mountain terrane are well mapped in the Finlayson Lake area in Yukon (Murphy and others, 2006). The extents of other thrust faults mapped in the YTT, such as the Yukon River Shear Zone (Parsons and others, 2018), are unclear because the fault traces are covered by Cretaceous volcanic or sedimentary rocks or have been reactivated during mid-Cretaceous extension. Thrust vergence on the Cleaver Lake and Money Creek thrusts in the Finlayson Lake district is northeast-directed and is interpreted as Early Permian by Murphy and others (2006). Top-to-the-northeast shear is also recorded in the Fortymile River assemblage in eastern Alaska, which is interpreted as pre-Late Triassic $(-212 \mathrm{Ma})$ shear (Hansen and Dusel-Bacon, 1998). Thrust vergence on the Yukon River shear zone is northwest-directed (Parsons and others, 2018) and matches a second shear direction in the Fortymile River assemblage, which is top-to-the-northwest and is interpreted as Late Triassic-Early Jurassic (Hansen and Dusel-Bacon, 1998).

A low-angle shear zone is poorly exposed between the Fortymile River assemblage of YTT and the parautochthonous Lake George assemblage and Divide Mountain augen gneisses in the northeast Tanacross map area (Hansen and Dusel-Bacon, 1998; Wypych and others, 2021). Jurassic ${ }^{40} \mathrm{Ar} /{ }^{39} \mathrm{Ar}$ cooling ages in the hanging wall of the shear zone and mid-Cretaceous ${ }^{40} \mathrm{Ar} /{ }^{39} \mathrm{Ar}$ cooling ages in the footwall suggest the shear zone is an extensional detachment (Dusel-Bacon and others, 2002; Naibert and others, 2020). Hansen and DuselBacon (1998) report top-to-the-southeast shear in 
the detachment zone and throughout the footwall rocks. Similar mid-Cretaceous extension is proposed for other low-angle extensional structures in eastern Alaska, such as the Salcha River gneiss dome (Pavlis and others, 1993; Hansen and Dusel-Bacon, 1998).

The right-lateral Denali and Tintina faults are major crustal features that bound the Yukon Tanana Upland in eastern Alaska. A prominent set of northeast-striking faults cuts the upland between these two faults. These faults are interpreted to have left-lateral-oblique motion (Day and others, 2014) and are intruded by mid-Cretaceous intrusions in multiple places, indicating northeast-striking faults are at least that old. Northeast-striking faults offset
Holocene deposits in some locations, indicating that some of the faults are long-lived features in the late Mesozoic through the Cenozoic (Day and others, 2014) or that multiple episodes of faulting occurred along similarly oriented faults. Additional high-angle fault orientations, including northwest-southeast, are also mapped in the region but are less-well understood (for example, Gordey and Ryan, 2005; Solie and others, 2019; Wypych and others, 2021). Interpreting the map patterns of Triassic to Jurassic contractional and mid-Cretaceous extensional structures separating the YTT from pNA are complicated by subsequent Cenozoic motion on these high-angle faults.

\section{DESCRIPTION OF MAP UNITS Sedimentary Rocks}

GrKs SEDIMENTARY ROCKS (CENOZOIC-CRETACEOUS)—Mixed unit of poorly-sorted, volcaniclastic to siliciclastic conglomerate and sandstone. Conglomerate grain size varies between locations, with cobbles commonly up to $10 \mathrm{~cm}$ and rare boulders up to $50 \mathrm{~cm}$ in diameter. Clasts vary from subangular to subrounded, and volcanic clasts typically dominate the coarse fraction, but metamorphic lithologies and detrital quartz and feldspar are also present, particularly among the smaller fraction. Volcanic clasts include dacite, rhyolite, and rhyolite tuff. The matrix ranges from poorly sorted brown tuffaceous silt to fine-grained plagioclase- and quartz-rich sand and silt. Sandstones are typically fine- to medium-grained, laminated, and poorly to moderately indurated. The unit has low to moderate magnetic susceptibility with a range of $0.01 \times 10^{-3}$ to $10.89 \times 10^{-3}$ Système International units (SI), with an average of $2.11 \times 10^{-3}$ SI and a median of $0.15 \times 10^{-3} \mathrm{SI}$.

Depositional ages of rocks included in this unit range from mid-Cretaceous through Miocene or younger, and multiple ages may be present in a single exposure (for example, see Foster and Igarashi, 1990). Consequently, the unit has depositional relationships with the Late Cretaceous and Paleogene volcanic rocks that would be problematic if it had a single discrete age. In the northwest quadrant of the map, unit GrKs lies stratigraphically above the West Fork Tuff (Kwff; 107.9 \pm 2.2 Ma; Wildland and others, 2021) and below the Late Cretaceous (?) alkaline volcanic rock unit (IKav); detrital zircons indicate mid-Cretaceous $(101.2 \pm 2.2 \mathrm{Ma})$ maximum depositional age (MDA) that is consistent with this stratigraphic relationship (19KS430; table 2; Twelker and O'Sullivan, 2021b). South of Mount Fairplay along the Taylor Highway, Foster and Igarashi (1990; site 2) report a fossil pollen assemblage that they interpret as representing a Miocene or younger depositional age, while $10 \mathrm{~km}$ to the south an isolated conglomerate exposure yielded a mid-Cretaceous detrital zircon MDA (19AW206; Twelker and O'Sullivan, 2021b). In the eastern map area, an isolated conglomerate exposure yielded a $-54 \mathrm{Ma}$ detrital zircon MDA (19KS149; Jones and O'Sullivan, 2020; Twelker and O'Sullivan, 2021b).

Similar sedimentary units are described by Wypych and others (2021) in the adjoining Northeast Tanacross map area, but the conglomerates in that area contain fewer volcanic clasts and more metamorphic clasts. This unit may correlate with the Indian River Formation in Yukon, which also consists of mixed conglomerates and sandstones that lie stratigraphically below the Late Cretaceous Carmacks volcanic 
group. Lowey and Hills (1988) assigned an Albian (ca. 113-100 Ma) age to the Tantalus Formation (Indian River Formation of Yukon Geological Survey, 2019) based on the presence of Albian palynomorphs. Conglomerates with Neogene depositional age may correlate with those in the Chicken area, as well as those north of Mount Fairplay (Foster and Igarashi, 1990).

\section{Volcanic rocks}

Per RHYOLITE (PALEOGENE) - Porphyritic rhyolite lava flows and lesser felsic tuff and volcaniclastic rocks. Rhyolite has an aphanitic groundmass, and phenocrysts include 2-mm-diameter quartz (10 percent), 1-mm-long feldspar (5 percent), and 3 percent angular lithic clasts of volcanic material in a devitrified matrix. Some flow banding is present. Liesegang-banded ash fall tuff is white to tan, with up to 5 percent quartz, 2 percent feldspar, and 1 percent biotite phenocrysts in a tuffaceous matrix. It contains alternating bands of crystal-bearing and crystal-poor tuff. Locally, it contains rounded lithic fragments 1 $\mathrm{cm}$ or less in diameter. The unit displays rare alteration of feldspar phenocrysts to sericite or clay, and is not known to be significantly mineralized. The main exposure of this unit lies about $10 \mathrm{~km}$ north of Ladue River where it is apparently on the order of 1,000 m thick; however, we mapped isolated occurrences (or its intrusive equivalent, $P_{E} f p$ ) farther west at the Oreo Mountain porphyry copper-molybdenum prospect and along the Taylor Highway. The magnetic susceptibility varies between 0.024 and $6.59 \times 10^{-3}$ SI, and averages at $2.4 \times 10^{-3} \mathrm{SI}$. Unit PEr is geochemically distinctive in that many samples contain high yttrium (40-100 ppm; see chapter E). The age of this unit is constrained by a U-Pb zircon age of $58.9 \pm 1.4 \mathrm{Ma}$ (sample 19AW256; Wildland and others, 2021). Sanidine from a welded tuff from this unit yielded a 57.8 $\pm 3.4 \mathrm{Ma} \mathrm{K}-$ Ar age (Foster and others, 1976, recalculated by Wilson and others, 2015).

IKfv FELSIC VOLCANIC ROCKS (LATE CRETACEOUS)_Silicic tuff, porphyritic rhyolite and dacite, and lesser silicic volcaniclastic rocks and breccias. Pale to dark gray with tints of green or blue, weathering to pale, greenish, or reddish brown. Silicic tuff has sericitized feldspar phenocrysts up to $15 \mathrm{~mm}$ long (up to 20 percent), fragmented quartz (10 percent), chlorite (5 percent), biotite (5 percent), opaque minerals, and lithic clasts as large as $45 \mathrm{~mm}$ in diameter (up to 10 percent). Matrix is aphanitic or tuffaceous. Lithic fragments include metamorphic rocks, and the matrix contains flattened pumice fragments. The rocks display weak alteration. Magnetic susceptibility of this unit varies greatly between lithologies, ranging from 0.027 to $23.64 \times 10^{-3} \mathrm{SI}$ and averaging $2.90 \times 10^{-3} \mathrm{SI}$. The volcanic rocks of this unit in the map area reach upwards of $250 \mathrm{~m}$ thick and are concentrated mostly in the valley of the East Fork of the Dennison Fork of the Fortymile River. A volcaniclastic conglomerate assigned to this unit yielded a detrital zircon MDA of $65.8 \pm 1.9 \mathrm{Ma}$ (19ET330; table 2; Twelker and O'Sullivan, 2021b); more broadly, the age of this unit is also constrained by its depositional relationship above the mid-Cretaceous West Fork felsic tuff (Kwff) and by inferred correlation to the Upper Cretaceous volcanic rocks in the adjacent Northeast Tanacross geologic map (Wypych and others, 2021) and to the Carmacks volcanic rocks in Yukon (Yukon Geological Survey, 2019).

IKav ALKALINE VOLCANIC ROCKS (LATE CRETACEOUS)_Porphyritic basaltic trachyandesite to trachydacite lava flows, tuffs and lesser volcaniclastic rocks and breccias. The volcanic flows are gray, pale gray, green-gray, reddish-brown, and maroon, weathering maroon, or brown, with up to 10 -mm-long phenocrysts and 20-mm-diameter lithic fragments in aphanitic matrix. The phenocrysts are composed of plagioclase (up to 25 percent), orthopyroxene (up to 25 percent), clinopyroxene (up to 15 percent), biotite (up to 5 percent), magnetite (up to 5 percent), other opaque minerals (up to 5 percent), hornblende (up to 3 percent), and local muscovite. The trachydacite lithologies have up to 5 percent quartz, whereas the basaltic trachyandesites have up to 5 percent olivine. Plagioclase and orthopyroxene are commonly twinned. Mafic minerals are often altered. Pyroxenes have opaque mineral inclusions, are altered to amphibole and chlorite in very fine-grained matrix and are often recrystallized. Some samples contain aligned feldspar laths and hints of flow banding. Rare, disseminated pyrite and vein mineralization are 
present. The unit is characterized by higher magnetic susceptibility than the surrounding rocks, ranging from 0.028 to $52.3 \times 10^{-3} \mathrm{SI}$ and averaging $10.35 \times 10^{-3} \mathrm{SI}$. This unit is interpreted to stratigraphically overlie sedimentary unit $\mathrm{GrKs}$; it is relatively thin, having an estimated thickness of no more than 100 m. It outcrops to the east and south of Mount Fairplay. We interpret this unit to be Late Cretaceous, based on similarities in geochemical composition to other Late Cretaceous alkalic suites, compositional similarities to the Late Cretaceous Carmacks volcanic suite in Yukon (Yukon Geological Survey, 2019), and our observation that it overlies mid-Cretaceous West Fork felsic tuff (unit Kwff).

Kwff WEST FORK FELSIC TUFF (MID-CRETACEOUS)— Rhyolite to dacite tuffs and subordinate rhyolite to dacite flows over a large (ca. 500-sq-km) volcanic field in the northwestern corner of the map area. Unit is predominantly light tan, with lesser gray, pale green, pale yellow, or maroon; it weathers brown, orange, or greenish maroon. Tuffaceous lithologies are matrix-supported, moderately sorted, crystal rich, and contain up to 10 percent lithic fragments up to $50 \mathrm{~mm}$ in diameter. The crystal fraction is euhedral to fragmented. Mineralogy commonly includes around 3 percent quartz, locally up to 25 percent; around 6 percent feldspar, locally up to 15 percent; biotite is present in some samples (2 percent), and hornblende occurs rarely. Other minerals include disseminated pyrite and hematite. Lithic fragments consist of very fine-grained, subangular volcanic rocks, flattened pumice fragments, and lapilli. Volcanic flow lithologies are locally laminated and are typically porphyritic, having around 3 percent (locally up to 30 percent) feldspar phenocrysts, 1 to 2 percent quartz phenocrysts, and 1 to 3 percent disseminated, oxidized pyrite, 1 percent hematite, and up to 90 percent aphanitic groundmass. Pyrite mineralization and argillic or sericitic alteration were observed locally. This unit has a low magnetic susceptibility, ranging from 0.02 to $8.96 \times 10^{-3}$ SI and averaging $1.51 \times 10^{-3}$ SI. A sample of tuff yielded a $107.9 \pm 2.2 \mathrm{Ma}$ zircon crystallization age (19TJN299; Wildland and others, 2021). Bacon and others (1990) interpreted this unit as one of several remnant volcanic calderas in the region.

Kmv VOLCANIC ROCKS OF MCARTHUR CREEK AREA (CRETACEOUS)—Small trachydacite to rhyolite volcanic flows and lesser breccias and ash falls occurring in the upper McArthur Creek drainage. Volcanic flows are porphyritic, with some flow banding. Phenocrysts, up to 3-mm long, include up to 15 percent plagioclase, 10 percent hornblende, and 3 percent quartz. Up to 10 percent secondary opaque minerals, probably magnetite, replace hornblende. Groundmass is very fine-grained devitrified glass. Ash falls are tuffaceous, lithic rich, and pumice rich. Subrounded lithic clasts are of volcanic material. Matrix is altered, with rare, fragmented quartz phenocrysts, some completely chloritized mafic minerals and secondary biotite clots. The rock is highly altered or weathered, with pumice fragments partially or completely weathered out. Average magnetic susceptibility of this unit is $1.20 \times 10^{-3} \mathrm{SI}$ but varies between 0.02 and $4.62 \times 10^{-3}$ SI. The maximum age of this unit is constrained by its deposition on the exhumed mid-Cretaceous granodiorite batholith (unit Kgd; 100-108 Ma [Wildland and others, 2021]).

\section{Paleogene intrusive rocks}

PEfp FELSIC PORPHYRY (PALEOGENE) —Dikes and small intrusions of felsic porphyry and lesser granite. Dikes contain up to 6-mm phenocrysts in an aphanitic or fine-grained matrix. The phenocrysts include 2 to 20 percent quartz, up to 10 percent feldspar, 5 percent muscovite, 3 percent plagioclase, 3 percent magnetite, 2 percent opaque minerals, and 1 percent biotite. Matrix is aphanitic, glassy (50 to 100 percent devitrified), and in some cases recrystallized. Phenocrysts are euhedral to subhedral; quartz is slightly resorbed and often fractured, and feldspars are altered to sericite. The less abundant equigranular to porphyritic granite is fine- to medium-grained, and has 50 to 70 percent feldspar, 25 to 45 percent quartz, and about 5 percent biotite. Symplectite textures are observed in the fine-grained matrix. Some samples have sparse disseminated or veinlet-hosted pyrite, and vuggy quartz veins with disseminated pyrite weathering to iron oxides. Magnetic susceptibility of this unit varies between 0.005 and 5.35, with an average of $1.36 \times 10^{-3} \mathrm{SI}$. Zircons from two samples of this unit yielded ages of $57.1 \pm 1.2$ and 58.6 
$\pm 1.4 \mathrm{Ma}$ (samples $18 \mathrm{KS} 100$ and 19ET277; Wildland and others, 2021). The equivalent unit in Yukon, the North Ladue River porphyry, yielded a U-Pb zircon age of 58.3 $\pm 0.5 \mathrm{Ma}$ (Yukon Geological Survey, 2020). This unit is of similar age and geochemistry to unit PEr (see chapter E) and we interpret it to be the intrusive equivalent of that unit. We mapped unit PEfp in the Pushbush copper-molybdenum prospect area, where it is barren and apparently postdates mineralized mid-Cretaceous granite (see chapter F). This unit occurs at the Oreo Mountain copper-molybdenum prospect as post-mineralization rhyolite dikes intercepted in drilling (Kennecott Exploration, 2019; see chapter F).

\section{Late Cretaceous intrusive rocks}

IKfd FELSIC DIKES (LATE CRETACEOUS)—Granite porphyry dikes, some of which are hydrothermally altered. The dikes contain 1-3 mm phenocrysts of alkali feldspar (5-10 percent), quartz (0-10 percent), altered plagioclase (5-10 percent), and biotite (0-5 percent, mostly altered to chlorite) in an aphanitic matrix consisting of very fine-grained quartz, sericite, and feldspar. Pyrite and/or tourmaline are locally present as veinlets or disseminated replacements. Magnetic susceptibility is low $\left(0.03-5 \times 10^{-3} \mathrm{SI}\right.$, average $0.8 \times 10^{-3} \mathrm{SI}$ ) reflecting their felsic nature and extensive hydrothermal alteration. A sample of this unit yielded a U-Pb zircon crystallization age of 70.5 $\pm 1.6 \mathrm{Ma}(19 \mathrm{RN} 359$; Wildland and others, 2021).

IKma MAFIC ALKALINE DIKES (LATE CRETACEOUS?)—Low-quartz dikes with compositions plotting in the alkali basalt field. Based largely on hand-held XRF data, samples range from alkali gabbro to monzonite with porphyritic to sub-equigranular textures. Feldspar (10-50 percent) is an essential component; mafic minerals are generally altered and include variable combinations of clinopyroxene, hornblende, and biotite. Abundant epidote (5-25 percent) is an important alteration mineral along with albite and calcite. Magnetic susceptibility is highly variable $\left(0.6-58 \times 10^{-3} \mathrm{SI}\right)$, but commonly high (average $14 \times 10^{-3} \mathrm{SI}$ ) reflecting both primary igneous character and subsequent hydrothermal alteration. Age assignment is based on proximity of many of the dikes to the Mount Fairplay igneous complex and similarity in chemical composition; this unit also crosscuts the main body of unit $1 \mathrm{Kgqm}$ at Mount Fairplay and must therefore be Late Cretaceous or younger.

IKgd GRANODIORITE TO GRANITE (LATE CRETACEOUS)—Dikes and stocks of fine- to medium-grained granodiorite to granite. Holocrystalline variants are porphyritic, seriate, or equigranular, with grain size ranging from 0.1 to $25 \mathrm{~mm}$. Mineralogy includes 10 to 55 percent plagioclase, 1 to 25 percent hornblende, up to 25 percent quartz and alkali feldspar, 0.5 to 18 percent biotite, 1 to 6 percent magnetite, and up to 1 percent secondary chlorite. Porphyry intrusions have an aphanitic, locally amygdaloidal groundmass, and up-to-10-mm phenocrysts including plagioclase (1 to 15 percent), hornblende (up to 5 percent), biotite ( 2 percent), clinopyroxene ( 2 percent), quartz ( 2 percent). Alteration includes sericitized feldspars, quartz-tourmaline veinlets and disseminated tourmaline, quartz-sulfide veinlets, and disseminated pyrite. At the Oreo Mountain prospect, alteration includes potassic assemblages including secondary biotite and potassium feldspar associated with quartz sulfide veins (see chapter F). The magnetic susceptibility of this unit is between 0.03 and $62.04 \times 10^{-3} \mathrm{SI}$, averaging $7.13 \times 10^{-3} \mathrm{SI}$. Three samples have been dated using U-Pb methods: a sample collected just south of Big Creek yielded 69.3 $\pm 1.4 \mathrm{Ma}$ (19WCW037), and two samples from Oreo Mountain porphyry prospect yielded $71.4 \pm 1.4$ and $72.1 \pm 1.6 \mathrm{Ma}(19 \mathrm{TJN} 243$ and 19RN282; table 1; Wildland and others, 2021).

IKpg PORPHYRITIC GRANITE (LATE CRETACEOUS)—A fault-bounded intrusion of porphyritic granite exposed west of the Oreo Mountain porphyry prospect. Porphyritic, hypidiomorphic, and characterized by large, sub- to euhedral alkali feldspar phenocrysts up to 20 -mm-long. The phenocrysts have biotite and titanite inclusions. The matrix comprises 1- to 5-mm-long minerals: up to 40 percent plagioclase, 10 to 20 percent quartz, up to 15 percent hornblende, 10 to 12 percent biotite, up to 3 percent 
magnetite, 3 percent titanite, and up to 5 percent secondary chlorite. Plagioclase has perthitic exsolution and is partially to highly sericitized, euhedral to subhedral quartz displays undulatory extinction, subhedral hornblende is chloritized, biotite is slightly chloritized and has zircon inclusions. Secondary chlorite forms clots near biotite and hornblende. The unit has an average magnetic susceptibility of $9.17 \times 10^{-3}$ SI, which may vary between 0.31 to $19.64 \times 10^{-3} \mathrm{SI}$. A sample of the porphyritic granite yielded a U-Pb zircon crystallization age of $68.8 \pm 1.5 \mathrm{Ma}$ (19RN287; table 1; Wildland and others, 2021).

\section{Late Cretaceous intrusive rocks of the Mount Fairplay complex}

As described in the detailed petrological studies of the area (Kerin, 1976; Newberry, 2020), the Mount Fairplay igneous complex comprises two major rock groups: (1) those containing normative feldspathoids or little to no quartz, and (2) those containing significant quartz. The former group, the alkalic group, includes monzonite $(\mathrm{lKm})$, syenite (lKsy), and rare alkali-feldspar syenite (lKafs); the latter, sub-alkalic group, comprises quartz monzonite and granite $(\mathrm{Kgqm})$. The quartz-rich and quartz-poor rocks both contain relatively anomalous thorium (Th; greater than $30 \mathrm{ppm}$ ), are closely coeval, and both contain diopsidic clinopyroxene. For these reasons, the alkalic and subalkaline rocks of the Mount Fairplay complex appear to be related. For additional results of our work at Mount Fairplay please refer to Newberry (2020).

IKgqm GRANITE AND QUARTZ MONZONITE (LATE CRETACEOUS) —A small (approximately $10-\mathrm{sq}-\mathrm{km}$ ) body that constitutes the core of the Mount Fairplay igneous complex. The body is mostly diopside-hornblende-biotite granite, but locally (with lower quartz content) diopside-hornblende-biotite quartz monzonite. Both types are usually fine-to medium-grained, sub-equigranular to porphyritic, with alkali feldspar (25-40 percent) up to $15 \mathrm{~mm}$. Dikes are all porphyritic. Quartz (10-30 percent) is usually $0.5-1 \mathrm{~mm}$, interstitial, and difficult to recognize in hand specimen. Plagioclase (30-40 percent, $1-4 \mathrm{~mm})$ is variably altered to sericite. Diopsidic clinopyroxene (1-10 percent, $0.2-0.5 \mathrm{~mm})$ is surrounded by hornblende (3-10 percent, $0.5-1 \mathrm{~mm}$ ) and (or) biotite (5-12 percent, $0.5-2 \mathrm{~mm}$ ) such that only biotite is readily visible in hand specimen. Minor minerals include 1-2 percent (mostly secondary?) titanite, $0.5-2$ percent (mostly primary?) magnetite, and 0.2-0.5 percent primary ilmenite. Magnetic susceptibility $\left(3 \times 10^{-3} \mathrm{SI}\right.$, average $\left.7 \times 10^{-3} \mathrm{SI}\right)$ is lower than that of the alkalic units (1Kafs, $\left.1 \mathrm{Km}, 1 \mathrm{Ksy}\right)$ and reflected in the low aeromagnetic signature for this unit (Emond and others, 2015). Dusel-Bacon and others (2015) determined a U-Pb SHRIMP zircon age of 66.5 \pm 1.1 Ma for this unit. Kerin (1976) noted textural evidence that this body is slightly younger than the enclosing syenite (unit $\mathrm{KKsy}$ ). Although this unit plots as subalkaline on a total alkali vs. silica diagram (Newberry, 2020), the presence of diopsidic clinopyroxene (similar in composition to such from alkaline phases of the body), proximity to the alkaline phases, and similarity in age, indicate that this body is broadly related to the enclosing, more alkalic parts of the Mount Fairplay complex.

ALKALI FELDSPAR SYENITE (LATE CRETACEOUS)—A small (less than 1-sq-km), dike-like body representing the most-fractionated of the alkalic rocks of the Mount Fairplay complex. Rocks from this unit have the highest uranium (U), Th, and rare earth element (REE) concentrations seen in the complex (Newberry, 2020). The rocks are fine- to medium-grained with 85-95 percent alkali feldspar (1-4 mm), 3-10 percent albitic plagioclase (1-2 mm), 0-3 percent quartz $(0.5-1 \mathrm{~mm}), 3-7$ percent biotite $(1-2 \mathrm{~mm})$, and $0-3$ percent hornblende $(0.3-1 \mathrm{~mm})$. Minor to trace minerals include titanite (secondary?), magnetite, fluorite (secondary?), and ilmenite. Plagioclase is commonly altered to sericite and biotite is extensively altered to chlorite. Magnetic susceptibility is highly variable, $1-32 \times 10^{-3} \mathrm{SI}$ (averaging $10 \times 10^{-3} \mathrm{SI}$ ) and reflects the variable magnetite content. The body has a dike-like shape and, based on chilled contacts, Kerin (1976) concluded that it intrudes other alkalic units (lKafs, lKm, IKsy). 
IKsy SYENITE (LATE CRETACEOUS)_An arcuate body that comprises the majority of the alkalic rocks of the Mount Fairplay igneous complex. It surrounds and is locally intruded by the central granite-quartz monzonite (Kerin, 1976). The three textural varieties include: medium- to coarsely porphyritic that comprises the majority of the unit; syenite pegmatite (confined to the northwest corner of the complex), which contains alkali feldspar crystals 5-10 cm long; and fine- to medium-grained porphyritic phases (confined to the southern margin of the complex), which contain 5-mm-long alkali feldspar crystals in a 0.5-2 mm matrix. The different textural types are mineralogically similar: 50-60 percent alkali feldspar (5-100 $\mathrm{mm}$ long), $15-25$ percent plagioclase $(0.5-2 \mathrm{~mm}), 0-1$ percent quartz $(0.3-0.5 \mathrm{~mm}), 15-20$ percent mafic minerals $(0.5-1.5 \mathrm{~mm}), 0.5-1$ percent apatite (less than $0.5 \mathrm{~mm}), 1-2$ percent magnetite $(0.2-0.5 \mathrm{~mm}), 0.5-1$ percent ilmenite $(0.1-0.3 \mathrm{~mm})$, and $0.5-1$ percent (secondary?) titanite. The mafic minerals commonly occur as multi-mineral aggregates, cored by calcium $(\mathrm{Ca})$-rich clinopyroxene $(2-7$ percent) that is usually surrounded by biotite (5-12 percent) and in turn surrounded by hornblende (1-5 percent). Texturally secondary chlorine $(\mathrm{Cl})$-rich biotite and (or) hornblende constitute up to one quarter of the mafic minerals (Newberry, 2020). Plagioclase is commonly altered; typically to sericite, locally to Cl-rich scapolite. Magnetic susceptibility is high (7-35 x $10^{-3} \mathrm{SI}$, average $\left.17 \times 10^{-3} \mathrm{SI}\right)$ and responsible for a significant aeromagnetic anomaly (Emond and others, 2015). This unit intrudes the 67 Ma monzonite $(1 \mathrm{Km})$ and is intruded by the $66.5 \mathrm{Ma}$ quartz monzonite $(\mathrm{Kgqm})$. Mount Fairplay igneous complex. Based on textural relations, it is the earliest intrusion in the complex (Kerin, 1976) and is the only unit that contains olivine $\left(\mathrm{Fa}_{63-74} ;\right.$ Newberry, 2020). Usually medium-grained, sub-equigranular, but also coarse porphyritic with alkali feldspar up to $3 \mathrm{~cm}$ in a medium-grained matrix. Minerals include 35-45 percent plagioclase $(1-4 \mathrm{~mm}), 30-40$ percent alkali feldspar (4-50 $\mathrm{mm}), 0-2$ percent quartz $(0.3-0.5 \mathrm{~mm}), 25-35$ percent mafic minerals (typically multi-mineral aggregates $1-3 \mathrm{~mm}), 1-2$ percent apatite $(0.3-0.5 \mathrm{~mm}), 1-3$ percent magnetite $(0.5-1 \mathrm{~mm}), 1$ percent ilmenite $(0.5 \mathrm{~mm})$, and $0-3$ percent (secondary?) titanite $(0.5-1 \mathrm{~mm})$. Unaltered olivine $(0-3$ percent, $0.3-0.7 \mathrm{~mm}$ ) occurs as inclusions in biotite (5-15 percent, $1-2 \mathrm{~mm}$ ); otherwise, former olivine occurs as fine-grained, hematite-quartz intergrowths. In either case, like clinopyroxene, it is invisible in hand specimen. Ca-rich clinopyroxene (4-7 percent, $0.5-1 \mathrm{~mm}$ ) is invariably surrounded by biotite and (or) hornblende (10-20 percent, $0.5-1.5 \mathrm{~mm})$ and is partly altered to actinolitic amphibole. Biotite is variably altered to chlorite and plagioclase to sericite and (or) epidote. Magnetic susceptibility is very high (8-48 x $10^{-3} \mathrm{SI}$, averaging $\left.25 \times 10^{-3} \mathrm{SI}\right)$ reflecting its significant magnetite content. The absolute age of this unit is constrained by a U-Pb zircon SHRIMP age of $67 \pm 1.5 \mathrm{Ma}$ (Dusel-Bacon and others (2015).

\section{Mid-Cretaceous intrusive rocks}

Kgp GRANITE PORPHYRY (MID-CRETACEOUS)—Dikes and stocks of granite porphyry and porphyritic granite generally concentrated in southwest quadrant of the map area south of Mount Fairplay. Grain sizes range from 0.001 to $12 \mathrm{~mm}$ depending on lithology. The most common lithologies are porphyry and porphyritic granite; these have an aphanitic to fine-grained matrix and phenocrysts (up to $10 \mathrm{~mm}$ ) composed of up to 40 percent quartz, 35 percent plagioclase, 10 percent hornblende, and 10 percent biotite. Accessory minerals include tourmaline, rutile, allanite, and secondary sericite, chlorite, and pyrite. Quartz is partially resorbed, sub- to euhedral, plagioclase is partially to completely sericitized, biotite is slightly to completely chloritized and hornblende is altered to chlorite and epidote. The aphanitic groundmass is devitrified; some samples are completely recrystallized to a mixture of feldspar and quartz, and some contain spherulites. Minor propylitic, sericitic and argillic alterations are present, with disseminated pyrite, iron oxides replacing pyrite, and sparse, hairline quartz veinlets. The magnetic susceptibility of this unit depends on the amount of weathering and alteration and varies between 0.006 
and $9.81 \times 10^{-3} \mathrm{SI}$, averaging $1.13 \times 10^{-3} \mathrm{SI}$. Four samples returned U-Pb zircon ages ranging from ca. 107 to $115 \mathrm{Ma}$ (Wildland and others, 2021). Dikes of this unit intrude both parautochthonous and allochthonous metamorphic units and post-date mid-Cretaceous granite $(\mathrm{Kg})$ and granodiorite $(\mathrm{Kgd})$.

Kmd MAFIC-INTERMEDIATE ALKALINE DIKES (MID-CRETACEOUS)_Basalt, basaltic trachyandesite, and trachyandesite dikes and small plugs intruding into the granodiorite batholith (unit $\mathrm{Kgd})$. Porphyritic, with aphanitic groundmass and up to 10-mm-long phenocrysts of euhedral plagioclase (5 percent), biotite (5 percent), and locally, resorbed quartz phenocrysts (up to 15 percent). Plagioclase is sericitized, biotite is largely chloritized, and hornblende is skeletal, partially altered to chlorite and secondary calcite (up to 15 percent). Up to $2 \mathrm{~mm}$ long secondary calcite crystallize in small, up to 10 -mm-diameter cavities. Groundmass is either devitrified glass or very fine-grained feldspar \pm quartz and biotite. The magnetic susceptibility varies between 0.03 and $25.78 \times 10^{-3} \mathrm{SI}$ and averages $7.19 \times 10^{-3}$ SI. Zircon from this unit yielded an age of $100.3 \pm 2.2 \mathrm{Ma}$ (Wildland and others, 2021). Joyce (2002) documents similar dikes at the Longline gold prospect in the adjacent Yukon. MAFIC TO INTERMEDIATE DIKES (MID-CRETACEOUS)_Basaltic andesite to andesite dikes and small intrusions in the granodiorite batholith (unit Kgd) in McArthur Creek area. Porphyritic, with aphanitic to fine-grained matrix, and up to 20-mm-long phenocrysts. Phenocrysts comprise up to 20 percent plagioclase, 20 percent hornblende, 15 percent quartz, 10 percent biotite, 5 percent magnetite, accessory allanite, and secondary chlorite. Plagioclase is sericitized, quartz is resorbed on the edges, hornblende is partially chloritized and, in some samples, skeletal, and biotite is highly altered to chlorite. The fine-grained groundmass is composed mostly of sericitized plagioclase with lesser quartz and hornblende. Some samples are veined and brecciated, and a few rocks have propylitic overprinting, some possible potassic alteration, and disseminated pyrite, chalcopyrite, and sparse quartz veinlets. Magnetic susceptibility varies between 0.02 and $19.58 \times 10^{-3} \mathrm{SI}$, with an average of $2.43 \times 10^{-3} \mathrm{SI}$. An andesite dike yielded a U-Pb zircon age $102.8 \pm 2.2 \mathrm{Ma}$, and a porphyry sampled at the nearby Pushbush prospect yielded a U-Pb zircon age of $110.7 \pm 2.5 \mathrm{Ma}$ (Wildland and others, 2021). Joyce (2002) documents similar dikes at the Longline gold prospect in the adjacent Yukon.

Kgd GRANODIORITE (MID-CRETACEOUS)_Batholith and plutons of granodiorite and lesser granite occupying more than $500 \mathrm{sq} \mathrm{km}$ in the southeast quadrant of the map. Unit is typically equigranular to seriate, hypidiomorphic, and less commonly porphyritic; locally the granodiorite is strained and is best described as orthogneiss. Grain size varies from 0.1 to $20 \mathrm{~mm}$. Mineralogy consists of 25 to 60 percent plagioclase, 10 to 45 percent quartz, up to 25 percent orthoclase, 15 to 20 percent microcline, 5 to 15 percent biotite, 1 to 19 percent hornblende, up to 2 percent augite, 2 percent magnetite, and trace titanite. 1 to $4 \mathrm{~mm}$ diameter interstitial quartz in some samples displays undulose extinction and can form granoblastic aggregates. Plagioclase is commonly zoned, up to $5 \mathrm{~mm}$ long, and partially sericitized; microcline is either interstitial or euhedral. Both biotite and hornblende are locally partially chloritized, and hornblende is locally partially replaced by epidote. Biotite forms rims on hornblende and augite, where present. The rocks are weakly altered to propylitic or sericitic assemblages. Most of the unit has no mineralization; however, unit Kgd granodiorite hosts polymetallic vein mineralization in the Moosehorn area (Honks, Move, and Goodrich Porphyry prospects; see chapter F). The local predominance of gneissic textures and the undulose extinction and granoblastic textures of quartz suggest this unit was emplaced prior to the end of Early Cretaceous regional ductile deformation. Magnetic susceptibility of this unit varies between 0.03 and $39.63 \times 10^{-3} \mathrm{SI}$ and averages $5.51 \times 10^{-3} \mathrm{SI}$. U-Pb zircon dating yielded ages of $104.2 \pm 2.3$ and $107.7 \pm 2.3 \mathrm{Ma}$ (Wildland and others, 2021); the apparently correlative Silver Creek Granodiorite (unit Khgd) from the adjacent Alaska Highway Corridor geologic map (Solie and others, 2019) yielded ages between ca. 97 and $103 \mathrm{Ma}$ (Solie and others, 2014). 
Kgb GABBRO TO DIORITE (MID-CRETACEOUS)_One or more small plugs or dikes of hornblende gabbro to diorite, possibly grading into the adjacent granite and comprising a zoned intrusive complex. Rocks of this unit are granophyric, equigranular, and have grain size varying between 1 and $10 \mathrm{~mm}$. Unit is composed of 40 to 70 percent plagioclase, 7 to 60 percent euhedral to anhedral hornblende, up to 20 percent anhedral quartz, up to 15 percent subhedral biotite, up to 20 percent anhedral alkali feldspar, ilmenite and magnetite and secondary actinolite, chlorite, epidote and sericite. Plagioclase is interlocking, strongly zoned and slightly sericitized. Up to $10-\mathrm{mm}$-long hornblende is poikilitic, with plagioclase inclusions and partially altered to biotite or actinolite. Biotite is primary as well as secondary, and is altered to chlorite, epidote and titanite. Interstitial quartz has moderate undulose extinction. No mineralization was noted. The magnetic susceptibility depends on magnetite composition of the rock and varies between 0.30 and $11.05 \times 10^{-3} \mathrm{SI}$ and averages $4.13 \times 10^{-3} \mathrm{SI}$. Unit yielded a U-Pb zircon age of $108.1 \pm 2.3 \mathrm{Ma}$ (Wildland and others, 2021). The equivalent of this unit in the Alaska Highway Corridor Map (unit Kgb) yielded a zircon age of $103.8 \pm 2.7 \mathrm{Ma}$ (Solie and others, 2014) and an ${ }^{40} \mathrm{Ar} /{ }^{39} \mathrm{Ar}$ age on biotite is slightly younger at $100.4 \pm 3.2 \mathrm{Ma}$ (Solie and others, 2013).

Kg GRANITE (MID-CRETACEOUS)_Biotite-bearing peraluminous granite stocks and intrusions, with aplite and pegmatite dikes of similar composition. Granite is tan, cream, or light gray to pale pink, seriate to equigranular, hypidiomorphic, with grain size between 0.1 and $35 \mathrm{~mm}$. Typically the granite has up to up to 60 percent subhedral alkali feldspar, 30 percent plagioclase, 35 percent quartz, 10 percent biotite, 3 percent primary white mica, accessory tourmaline, rutile and zircon and secondary chlorite, sericite, and clay minerals. The alkali feldspar is mostly orthoclase, albite is zoned, plagioclase is sericitized. Some of the interstitial quartz is recrystallized to form granoblastic aggregates and has undulose extinction. Biotite is partially chloritized, is intergrown with muscovite, and has abundant zircon damage zones. Locally altered to clay and chlorite but is generally fresh with rare veins of pyrite.

Pegmatite dikes are similar in composition to the granite, with up to 50-mm-long euhedral orthoclase and microcline crystals in a matrix of about 10 -mm-diameter quartz and plagioclase. Thin books of biotite between 50 and $70 \mathrm{~mm}$ in diameter are found irregularly throughout the rock. Biotite is slightly chloritized on margins and forms up to 5 percent of the rock.

Aplite dikes are light gray and equigranular, with grain sizes between 0.5 and $2 \mathrm{~mm}$. Mineralogy is similar to the larger granitic intrusions and includes rare metamorphic xenoliths. Locally altered with up to 1 percent disseminated pyrite, sparse quartz veinlets, sericite, and local tourmaline clots (up to 0.1 percent). The granites, pegmatites, and aplites are characterized by low magnetic susceptibility, ranging between 0 and 1.5 and averaging $0.3 \times 10^{-3}$ SI. Five samples of this unit from within the map area yielded U-Pb zircon ages ranging from 106.7 to $112.8 \mathrm{Ma}$ (Wildland and others, 2021). Equivalent granite and pegmatite (unit $\mathrm{Kg}$ ) in the adjacent Northeast Tanacross geologic map yielded a zircon $\mathrm{U}-\mathrm{Pb}$ age of $114.1 \pm 1.4 \mathrm{Ma}$ (Wypych and others, 2020) and ${ }^{40} \mathrm{Ar} /{ }^{39} \mathrm{Ar}$ ages ranging from ca. 105 to $110 \mathrm{Ma}$ (Naibert and others, 2018). On the eastern edge of the Tanacross Quadrangle, the granite extends into Yukon, Canada, where it is mapped as the ca. 110-109 Ma Crag Mountain pluton, part of the Whitehorse Plutonic Suite (Yukon Geological Survey, 2019). The granite has similar age and composition to other granites in the Yukon such as the Dawson Range batholith, the Coffee Creek granite, and the Moosehorn Range granitoids (Allan and others, 2013).

\section{METAMORPHIC ROCKS Allochthonous rocks of the Seventymile terrane}

SERPENTINITE (TRIASSIC-MISSISSIPPIAN) - Two bodies of greenschist-facies, mostly ultramafic rock occurring at the boundary between rocks of the parautochthonous Lake George assemblage 
and those of the allochthonous terranes, suggesting that this unit is part of a suture zone between these different tectonic assemblages. Unit consists of predominantly fine- to medium-grained meta-dunite and meta-clinopyroxenite, but likely includes some metamafic rock and may include tectonic slivers of other rock types. Serpentinite (meta-dunite) is $90-95$ percent serpentine $(0.05-0.2 \mathrm{~mm}), 0-5$ percent dolomite and magnesite $(0.05-0.1 \mathrm{~mm}), 0.5-5$ percent Cr-magnetite $(0.02-0.3 \mathrm{~mm})$, and $1-5$ percent chlorite $(0.05-0.1 \mathrm{~mm})$. Meta-clinopyroxenite (tremolite-chlorite rock) is $65-85$ percent randomly oriented tremolite needles $(0.4-2 \mathrm{~mm}), 15-30$ percent chlorite $(0.2-0.5 \mathrm{~mm}), 0.5-1$ percent ilmenite $(0.05 \mathrm{~mm})$, and $0.5-2$ percent magnetite $(0.05-0.1 \mathrm{~mm})$, and $0-7$ percent albite $(0.5-1 \mathrm{~mm})$. These minerals, and the lack of other diagnostic metamorphic minerals, were confirmed by microprobe. Magnetic susceptibility is extremely variable $\left(0.2-247 \times 10^{-3} \mathrm{SI}\right.$, average $\left.59 \times 10^{-3} \mathrm{SI}\right)$, reflecting the rock type variability. The age of this unit is based on our interpretation that it belongs to the Seventymile terrane, which includes Mississippian to Upper Triassic sedimentary rocks (Foster and others, 1994).

\section{Allochthonous metamorphic rocks of the Klondike assemblage}

The Klondike assemblage is exposed along the eastern edge of the map area adjacent to the Alaska-Yukon border. The contact of the Klondike assemblage units with other allochthonous Yukon-Tanana Terrane units is interpreted as one or more low-angle faults due to abrupt change in metamorphic grade between the greenschist-facies Klondike assemblage and the amphibolite-facies Ladue River area units (see chapter B). The Klondike units are also in low-angle fault contact with the parautochthonous Lake George assemblage. Faults at the base of the Klondike are intruded by small Cretaceous granite $(\mathrm{Kg})$ plutons, indicating that faulting occurred prior to the mid-Cretaceous. Late Cretaceous and Paleogene volcanic units sit unconformably on top of the Klondike assemblage in the eastern part of the map area, indicating the Klondike assemblage has been at the surface since the Late Cretaceous without significant regional erosion or deformation. This assemblage is mapped across the border in Yukon, where it overlies rocks of the Snowcap assemblage or the Finlayson assemblage (Gordey and Ryan, 2005; Ryan and others, 2013).

The age of this assemblage is based on felsic schist samples yielding Permian zircon ages (Jones and O'Sullivan, 2020; Wildland and others, 2021). Felsic schist is a minor lithology in Pks in our map area, and we interpret these layers as depositionally interlayered felsic volcanic rocks. It is possible that the dated rocks are metamorphosed intrusions. Nevertheless, we feel justified in correlating these rocks with the Klondike assemblage of Gordey and Ryan (2005) in the adjacent Stewart River area of Yukon.

Pks SCHIST (PERMIAN)—A mixed unit consisting of chlorite schist, muscovite schist, and semischist of mixed sedimentary and volcanic protoliths, as well as minor felsic schist interpreted as metarhyolite. Unit also contains minor quartzite, porphyroclastic orthogneiss, and rare metaconglomerate. Outcrops are generally pale green to dark green to gray and grain size ranges from 0.1 to $2 \mathrm{~mm}$, locally with phenocrysts in the metarhyolite unit up to $10 \mathrm{~mm}$. Unit is schistose, crenulated on the sub-cm scale, and the dominant foliation is often folded at the decimeter to meter scale. Greenschist-facies mineralogy and the relatively fine-grained, schistose texture suggest that this unit never reached amphibolite-facies conditions experienced by the other metamorphic rocks in the map area. Mineralogy includes 30-60 percent quartz, up to 40 percent actinolite, up to 40 percent albite, up to 15 percent muscovite, up to 15 percent biotite, up to 10 percent chlorite, and up to 5 percent epidote. Schists are locally iron stained and contain traces of pyrite along fracture surfaces and veinlets. Magnetic susceptibility ranges from 0.04 to $2.91 \times 10^{-3} \mathrm{SI}$, with an average of $0.89 \times 10^{-3} \mathrm{SI}$ and a median of $0.23 \times 10^{-3} \mathrm{SI}$. Felsic schist from this unit, interpreted as metarhyolite, yielded $\mathrm{U}-\mathrm{Pb}$ zircon ages of $256.7 \pm 5.8$ and $261.4 \pm 5.8 \mathrm{Ma}$ (table 1 ; Wildland and others, 2021). Jones and O'Sullivan (2020) obtained ages ranging from ca. 257 to 267 Ma from similar rocks in the area, supporting the correlation of this package to the Klondike Schist assemblage in Yukon. 
Pkgs GRAPHITIC SCHIST (PERMIAN) — A relatively thin, recessive-weathering unit distinguished by its locally significant graphite content and anomalously low resistivity that makes it easily mapped in airborne electromagnetic surveys (Burns and others, 2020a; AERODAT, 1977). Unit is dark gray to pale green, and grain size ranges from 0.1 to $5 \mathrm{~mm}$. Mineralogy includes up to 60 percent quartz, up to 40 percent plagioclase feldspar, up to 30 percent chlorite, up to 20 percent muscovite, and graphite. Diamond drilling at the Ladue Camp prospect intercepted $83 \mathrm{~m}$ of graphitic schist, including several thin bands of massive sulfide (Cities Service Minerals Corporation, 1980; see chapter F). Magnetic susceptibility has a restricted range of 0.05 to $0.25 \times 10^{-3} \mathrm{SI}$, with an average of $0.15 \times 10^{-3} \mathrm{SI}$.

Pkmb METABASITE (PERMIAN)_Dark gray to dark green schistose unit consisting of mafic to intermediate greenschist. Unit corresponds to highly magnetic bands in airborne magnetic survey (Burns and others, 2020a), which aided mapping. Mineralogy of the unit includes 40-60 percent chlorite, up to 40 percent actinolite, up to 40 percent albite, up to 10 percent epidote, up to 30 percent quartz, up to 10 percent white mica, up to 2 percent magnetite, and rare disseminated sulfides. High magnetic susceptibility ranging from 0.06 to $93.0 \times 10^{-3} \mathrm{SI}$, with an average of $13.59 \times 10^{-3} \mathrm{SI}$, and a median of $6.70 \times 10^{-3} \mathrm{SI}$.

\section{Allochthonous metamorphic rocks of the Ladue River unit}

Variably retrograded amphibolite-facies metamorphic rocks exposed along ridges surrounding the South Fork of the Ladue River are known as the Ladue River unit (Dusel-Bacon and others, 2006), although part of this unit as originally defined has been remapped as Klondike assemblage (Jones and others, 2017; this study). Metaigneous rocks of this unit crystallized during the Late Devonian to Early Mississippian; however, while some of these are clearly metaplutonic, others could have either volcanic or intrusive protoliths (fig. 3). Accordingly, the associated metasedimentary rocks could be as young as Early Mississippian or as old as Proterozoic.

The Ladue River unit has pre-Cretaceous ${ }^{40} \mathrm{Ar} /{ }^{39} \mathrm{Ar}$ cooling ages (table 3; Jones and Benowitz, 2020) that indicate it belongs to the allochthonous YTT. Beyond that, the potential regional correlations of this unit are open to debate. The quartz-rich metasedimentary rocks and relative scarcity of intercalated amphibolite layers in the Ladue River unit suggests some similarity to the pre-Mississippian Snowcap assemblage in Yukon (Colpron and others, 2006; Piercey and Colpron, 2009). The Ladue River unit contains fewer fine-grained orthogneisses and lacks the marble layers typically found in the Fortymile River assemblage
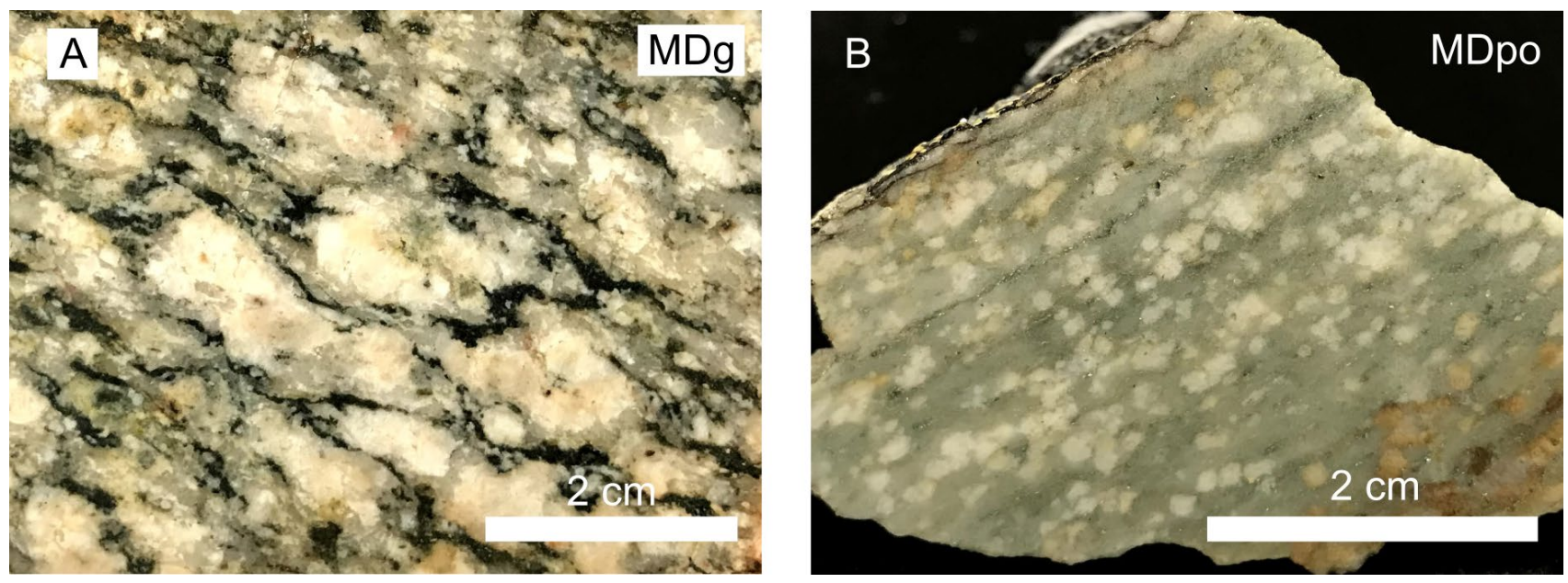

Figure 3. Hand sample photographs illustrating the textural differences between end member examples of unit MDg metagranitoid (A; sample 19RN157) and unit MDpo feldspar-porphyroclastic orthogneiss (B; sample 19ADW140). 
Table 3. Selected ${ }^{40} \mathrm{Ar} /{ }^{39} \mathrm{Ar}$ and $\mathrm{K}-\mathrm{Ar}$ ages used in the construction of this map. All ages are from Jones and Benowitz (2020) except for K-Ar age 74ASj111, which is from Foster and others (1976), recalculated in Wilson and others (2015).

\begin{tabular}{|c|c|c|c|c|c|c|c|c|}
\hline Sample & Latitude & Longitude & $\begin{array}{l}\text { Map } \\
\text { Unit }\end{array}$ & Lithology & $\begin{array}{l}\text { Sample } \\
\text { Material }\end{array}$ & $\begin{array}{c}\text { Preferred } \\
{ }^{40} \mathrm{Ar} /{ }^{39} \mathrm{Ar} \\
\text { Age }\end{array}$ & $\begin{array}{l}\text { Uncertainty } \\
\qquad(2 \sigma)\end{array}$ & $\begin{array}{l}\text { Preferred age type } \\
\text { and comments }\end{array}$ \\
\hline 14AJJ011 & 63.2035 & -141.0264 & MPlo & $\begin{array}{l}\text { biotite and } \\
\text { hornblende } \\
\text { gneiss }\end{array}$ & hornblende & 103.7 & 2.6 & $\begin{array}{l}\text { weighted average, } 1 \text { of } \\
8 \text { fractions, criteria not } \\
\text { met for plateau age }\end{array}$ \\
\hline 14AJJ019 & 63.3040 & -141.4625 & $\mathrm{MDg}$ & gneissic granite & muscovite & 253.2 & 4.4 & $\begin{array}{l}\text { weighted average, } 6 \text { of } \\
8 \text { fractions, criteria not } \\
\text { met for plateau }\end{array}$ \\
\hline 16AJJ211 & 63.34386 & -141.3678 & Pks & $\begin{array}{c}\text { leucocratic } \\
\text { quartzose } \\
\text { gneiss }\end{array}$ & muscovite & 236.1 & 2.6 & $\begin{array}{l}\text { weighted average, } 2 \text { of } \\
8 \text { fractions, criteria not } \\
\text { met for plateau }\end{array}$ \\
\hline 16AJJ216 & 63.5011 & -141.0933 & Melgs & $\begin{array}{c}\text { augen } \\
\text { orthogneiss }\end{array}$ & biotite & 111.7 & 2.4 & $\begin{array}{l}\text { plateau age; } 4 \text { of } 8 \\
\text { fractions }\end{array}$ \\
\hline 16AJJ221 & 63.4560 & -141.3952 & $\mathrm{MDg}$ & $\begin{array}{l}\text { muscovite } \\
\text { schist }\end{array}$ & muscovite & 238.1 & 4.4 & $\begin{array}{l}\text { weighted average, } 4 \text { of } \\
8 \text { fractions, criteria not } \\
\text { met for plateau age }\end{array}$ \\
\hline 16AJJ222 & 63.3005 & -141.4890 & Pks & mafic schist & muscovite & 223.8 & 5.4 & $\begin{array}{l}\text { weighted average, } 3 \text { of } \\
8 \text { fractions; criteria not } \\
\text { met for plateau }\end{array}$ \\
\hline 16AJJ272C & 63.4418 & -141.3889 & MDpo & $\begin{array}{l}\text { quartz } \\
\text { muscovite } \\
\text { schist }\end{array}$ & muscovite & 265.7 & 3.2 & $\begin{array}{l}\text { plateau age; } 6 \text { of } 8 \\
\text { fractions }\end{array}$ \\
\hline 17AJJ101 & 63.4616 & -141.5452 & $\mathrm{MDg}$ & $\begin{array}{c}\text { augen } \\
\text { orthogneiss }\end{array}$ & biotite & 92.7 & 2.2 & $\begin{array}{l}\text { plateau age; } 4 \text { of } 8 \\
\text { fractions }\end{array}$ \\
\hline 17AJJ101 & 63.4616 & -141.5452 & MDg & $\begin{array}{c}\text { augen } \\
\text { orthogneiss }\end{array}$ & muscovite & 183.6 & 3.4 & $\begin{array}{l}\text { plateau age; } 3 \text { of } 8 \\
\text { fractions }\end{array}$ \\
\hline 17AJJ104 & 63.2559 & -141.8648 & MDIgs & pelitic schist & muscovite & 99.6 & 1.8 & $\begin{array}{l}\text { plateau age; } 4 \text { of } 8 \\
\text { fractions }\end{array}$ \\
\hline 17AJJ105 & 63.1987 & -141.5678 & MPms & $\begin{array}{c}\text { biotite } \\
\text { orthogneiss }\end{array}$ & muscovite & 193.5 & 6.4 & $\begin{array}{l}\text { weighted average, } 2 \text { of } \\
8 \text { fractions; criteria not } \\
\text { met for plateau }\end{array}$ \\
\hline 17AJJ154 & 63.5159 & -141.4660 & Mems & $\begin{array}{l}\text { quartzose } \\
\text { schist }\end{array}$ & muscovite & 201.4 & 2.2 & $\begin{array}{l}\text { weighted average, } 2 \text { of } \\
8 \text { fractions; criteria not } \\
\text { met for plateau }\end{array}$ \\
\hline 17YTT001 & 63.2963 & -141.7208 & MPms & quartzite & muscovite & 190.7 & 8.0 & $\begin{array}{l}\text { weighted average, } 5 \text { of } \\
8 \text { fractions; criteria not } \\
\text { met for plateau }\end{array}$ \\
\hline 17YTT003 & 63.2361 & -141.4339 & $\mathrm{MDg}$ & orthogneiss & muscovite & 234.7 & 6.0 & $\begin{array}{l}\text { weighted average, } 2 \text { of } \\
8 \text { fractions; criteria not } \\
\text { met for plateau }\end{array}$ \\
\hline 74ASj111 & 63.4833 & -141.1330 & $\mathrm{PEr}$ & Tuff & Sanidine & 57.8 & 3.4 & $\mathrm{~K}-\mathrm{Ar}$ \\
\hline
\end{tabular}


(Wypych and others, 2021; Colpron and others, 2006); however, the trace-element composition of Ladue River unit amphibolites (unit MDa) is similar to that of Fortymile River amphibolites (see chapter C). As discussed in chapter B, metamafic rocks from the Ladue River area have similar plagioclase and hornblende compositions to those of the Fortymile River assemblage, suggesting a similar degree of metamorphism; however, this dataset is not available for the Snowcap assemblage. Key differences between the Ladue River units and the Fortymile River assemblage include: 1) Triassic-Jurassic plutons commonly found in the Fortymile River assemblage are absent in the Ladue River unit, and 2) the Ladue River unit has Late Triassic to Early Jurassic ${ }^{40} \mathrm{Ar} /{ }^{39} \mathrm{Ar}$ cooling ages (table 3; Jones and Benowitz, 2020), whereas Jurassic cooling ages predominate in the Fortymile River assemblage (Naibert and others, 2021) and the Snowcap assemblage (Yukon Geological Survey, 2020). We interpret these data to indicate that the Ladue River unit and Fortymile River assemblage may have shared a common Paleozoic history but became separated during the Mesozoic following peak metamorphism, and hence should be broken out as a separate unit.

MDg METAGRANITOID (EARLY MISSISSIPPIAN-LATE DEVONIAN)—Primarily medium- to coarse-grained orthogneiss of granite or granodiorite composition. Grain size ranges from 0.1 to $15 \mathrm{~mm}$. Unit is variably foliated, but much of unit preserves an equigranular igneous texture and may have only weak foliation in hand sample (fig. 3A). Moderately foliated outcrops have large, equant feldspar porphyroclasts. Unit exhibits amphibolite grade metamorphism and locally has been partially retrograded to greenschist-facies, as evidenced by chloritization of biotite and minor epidote. Mineralogy includes up to 50 percent plagioclase feldspar, 20-80 percent quartz, 20-40 percent alkali-feldspar, 10-55 percent muscovite, 2-40 percent biotite, up to 20 percent chlorite, up to 3 percent epidote, and trace garnet, epidote, titanite, and opaques. Amphibole is observed locally. Unit was most often observed on hilltops and along ridgelines, and shear zones or mylonites were observed at basal contacts, suggesting the unit is in fault contact with the underlying MEms and MDpo units. Magnetic susceptibility ranges from 0.02 to $9.65 \times 10^{-3} \mathrm{SI}$, with an average of $1.08 \times 10^{-3} \mathrm{SI}$ and a median of $0.14 \times 10^{-3} \mathrm{SI}$. U-Pb zircon ages in the map area range from ca. 358 to $376 \mathrm{Ma}$ (Jones and O'Sullivan, 2020; Wildland and others, 2021), suggesting a possible correlation to the Latest Devonian Grass Lakes plutonic suite in Yukon.

MDa AMPHIBOLITE (EARLY MISSISSIPPIAN-LATE DEVONIAN)—An amphibolite facies unit consisting mostly of metamorphosed mafic and lesser intermediate rocks. Fine- to medium-grained, schistose hornblende amphibolite (with partial to extensive greenschist-facies overprint) is the predominant rock type. Mineralogy is 40-60 percent hornblende $(0.3-2 \mathrm{~mm}), 10-20$ percent actinolite (rims and replaces hornblende, $0.2-0.5 \mathrm{~mm}$ ), 0-30 percent plagioclase porphyroblasts $\left(\mathrm{An}_{10-25}\right.$, replaced and (or) or rimmed by albite, $0.5-5 \mathrm{~mm}$ ), 10-30 percent albite (surrounds and replaces plagioclase, $0.5-2 \mathrm{~mm}$ ), $0.5-3$ percent titanite (subhedral, $0.1-0.4 \mathrm{~mm}$ ), $0-0.3$ percent rutile (as inclusions in titanite clusters, $0.05-0.1 \mathrm{~mm}$ ), $1-5$ percent biotite (partly altered to chlorite, $0.02-0.5 \mathrm{~mm}$ ), 3-15 percent chlorite (includes both coarse euhedral and replacement, $0.2-2 \mathrm{~mm}), 3-8$ percent subhedral clinozoisite $(0.3-0.7$ $\mathrm{mm}), 1-3$ percent phengitic muscovite $(0.1-0.4 \mathrm{~mm}), 0.1-0.5$ percent magnetite $(0.05-0.1 \mathrm{~mm})$, and $0-5$ percent quartz $(0.1-0.3 \mathrm{~mm})$. Meta-intermediate rock contains less hornblende and more quartz. Magnetic susceptibility is moderate $\left(0.1-23 \times 10^{-3} \mathrm{SI}\right.$, average $\left.4 \times 10^{-3} \mathrm{SI}\right)$ reflecting variable magnetite content. There is no conclusive evidence that distinguishes between a volcanic or intrusive origin for this unit. A U-Pb zircon age of $361.8 \pm 7.4 \mathrm{Ma}$ from one sample is the basis for the unit age (Wildland and others, 2021). MDa is distinguished from similar-appearing MDla of the Lake George assemblage by virtue of: 1) Absence of calcic plagioclase (see chapter B), garnet, and diopside; B) a more extensive greenschist-facies overprint; and, 3) the presence of clinozoisite instead of epidote and of minor phengitic muscovite. 
MDpo FELDSPAR-PORPHYROCLASTIC ORTHOGNEISS (EARLY MISSISSIPPIAN-LATE DEVONIAN)_Composed primarily of fine- to medium-grained porphyroclastic or porphyroblastic orthogneiss from granodiorite to granite composition (fig. 3B). Porphyroclast-bearing gneisses are interpreted as metamorphosed felsic porphyritic volcanic or shallow intrusive rocks. The orthogneisses form sill-like or sheet-like bodies within unit MPms. Amphibolite- and greenschist-facies mineral assemblages were observed in this unit, without a strong spatial pattern. Chlorite and epidote appear in thin section as rims on biotite and rarely garnet, or as pseudomorphs after those minerals, suggesting the greenschist-facies mineralogy is retrograde alteration of a peak-metamorphic, amphibolite-facies mineral assemblage. Orthogneiss mineralogy includes up to 60 percent plagioclase feldspar, 40-60 percent quartz, up to 45 percent alkali feldspar, 1-25 percent white mica, 1-40 percent biotite, up to 30 percent chlorite, up to 5 percent epidote, and rare garnet. Magnetic susceptibility ranges from 0.02 to $44.82 \times 10^{-3} \mathrm{SI}$, with an average of $1.22 \times 10^{-3} \mathrm{SI}$ and a median of $0.11 \times 10^{-3} \mathrm{SI}$. U-Pb ages in the map area range from ca. 356 to $357 \mathrm{Ma}$ (Jones and O’Sullivan, 2020).

MEms METASEDIMENTARY ROCKS (MISSISSIPPIAN-PROTEROZOIC?)_A composite unit consisting of interlayered paragneiss, quartz schist, semischist, and minor quartzite. Rare, weathered-out calcite-bearing quartzite and semischist was also observed; these were some of the only calcareous rocks in the map area. Sparse orthogneiss layers similar to unit MDpo were noted but were too thin to map. Unit is extensively foliated, as generally defined by micas with variable chloritization. Both amphibolite- and greenschist-facies mineralogy occur throughout the unit; greenschist-facies mineralogy likely represents retrograde conditions following peak metamorphism, as chlorite rims and replaces biotite and garnet. Color ranges from tan to gray to pale green. Grain size ranges from 0.01 to $6 \mathrm{~mm}$ in paragneiss, schist, and quartz schist layers, and up to $15 \mathrm{~mm}$ in quartzite layers. Mineralogy is variable but generally reflects siliciclastic protoliths, including 20 to 95 percent quartz, up to 30 percent albite, up to 60 percent white mica, up to 45 percent chlorite, up to 40 percent biotite, up to 60 percent feldspar, and trace to minor alkali-feldspar, epidote, and garnet. Quartzite and semischist rarely contain small amounts of graphite. Magnetic susceptibility ranges from a minimum of $0.01 \times 10^{-3} \mathrm{SI}$ to an extreme maximum of $26.98 \times 10^{-3} \mathrm{SI}$, with an average of $1.03 \times 10^{-3} \mathrm{SI}$ and a median of $0.12 \times 10^{-3} \mathrm{SI}$. The age of this unit is constrained only by its interlayered relationship with unit MDpo orthogneiss. If that unit has a volcanic protolith then the associated sedimentary rocks were likely deposited during the Late Devonian-Early Mississippian; if MDpo was emplaced as sills, MPms likely comprises the metamorphic equivalents of Neoproterozoic through Devonian Selwyn Basin lithologies.

\section{Parautochthonous rocks of the Jarvis belt}

Rocks of the Jarvis belt are part of pNA but are distinguished from the Lake George assemblage by their younger depositional ages, which are inferred from the presence of interlayered Mississippian-Devonian metavolcanic rocks (MDmr) and a corresponding absence of metaplutonic rocks of that age (MDag). While the Jarvis belt is broadly characterized by greenschist-facies mineralogy (Dashevsky and others, 2003; Sicard and others, 2017), relict hornblende and anorthite-rich plagioclase (see chapter B) indicate these rocks (like those of the Lake George assemblage) reached amphibolite-facies conditions prior to metamorphic cooling in the Early Cretaceous. These rocks are likely correlated with the White River complex in Yukon (Ryan and others, 2013).

kgs GREENSTONE (TRIASSIC?) - Fine-grained $(0.1-1 \mathrm{~mm})$, massive- to weakly foliated greenstone of basaltic composition. Color ranges from pale green to dark gray. Mineralogy is dominated by a retrograde assemblage of actinolite, albite, and epidote-group minerals. Solie and others (2019) identified chlorite and local biotite (possibly pseudomorphic after clinopyroxene) in unit kgs in their map of the adjacent area. Microprobe examination (see chapter B) reveals the presence of relict prograde metamorphic hornblende 
and plagioclase $\left(\mathrm{An}_{23-68}\right)$, and that hornblende and plagioclase locally retain cores of actinolite and albite, respectively, in addition to the retrograde overprint. Magnetic susceptibility ranges from 0.34 to $11.0 \times 10^{-3}$ SI and averages $4.98 \times 10^{-3} \mathrm{SI}$. Age is inferred to be Triassic based on a tentative correlation to dated Triassic metagabbros found in the Jarvis belt and White River Formation regionally (Solie and others, 2014; Murphy and others, 2009; and Ryan and others, 2013; Dashevsky and others, 2003).

MDmr METARHYOLITE (EARLY MISSISSIPPIAN-LATE DEVONIAN)_Weakly foliated, porphyritic metarhyolite with an aphanitic groundmass (fig. 4). Relict phenocrysts include: quartz, 1-2 mm grains, sub-rounded, showing undulose extinction or subgrain formation (5-25 percent); plagioclase, 1-2 mm, subhedral, partially to sericite (5 percent); alkali feldspar, $1-2 \mathrm{~mm}$, and also present locally as augen porphyroclasts up to $10 \mathrm{~mm}$ in diameter $(0-15$ percent); biotite, slightly chloritized to completely replaced by a mixture of oxides and secondary biotite $(0.5-1 \mathrm{~mm}, 0-2$ percent). Some phenocrysts have fragmental shapes suggesting the unit was originally deposited as a tuff. The groundmass comprises a mixture of very fine-grained quartz, white mica, and feldspar; aligned white micas ( -50 micron; 5-20 percent) define a weak metamorphic fabric and an incipient crenulation cleavage in some samples. Other groundmass minerals include trace epidote, chlorite, pyrite, and iron oxide. Magnetic susceptibility ranges from 0.035 to $3.74 \times 10^{-3} \mathrm{SI}$ and averages $0.40 \times 10^{-3} \mathrm{SI}$. Unit has been metamorphosed to amphibolite facies and subsequently retrograded to greenschist facies, based on the local presence of metamorphic biotite (partially replaced by chlorite) and by the presence of hornblende and high-anorthite plagioclase in interlayered metamafic rocks (kgs; samples 19ADW042, 19TJN024; see chapter B). The age of this unit is constrained by a U-Pb zircon age of $366.8 \pm 8.1 \mathrm{Ma}$ (19ET034; Wildland and others, 2021). Unit MDmr metarhyolite is probably the equivalent of "felsic schist and quartzite" (unit Ms) of Solie and others (2019); metarhyolite from that unit yielded a zircon age of 351.7 $\pm 9.3 \mathrm{Ma}$ (Solie and others, 2014).

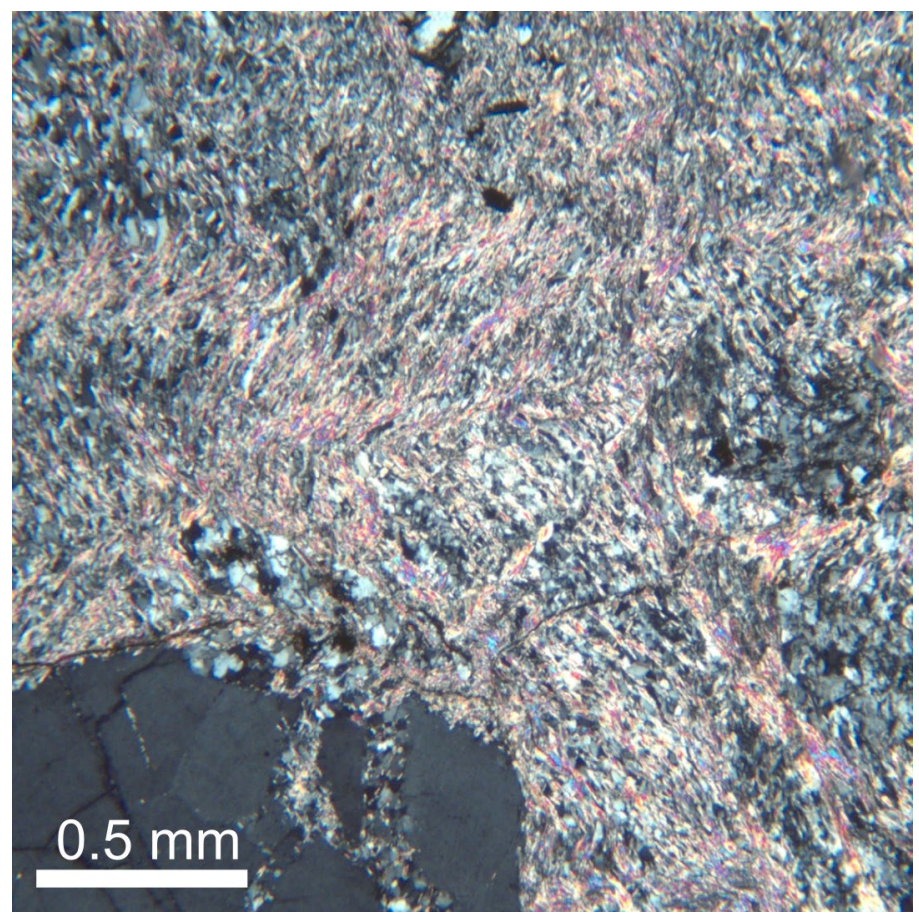

Figure 4. Photomicrograph of unit MDmr showing quartz phenocryst and very fine-grained groundmass with incipient, crenulated metamorphic fabric (sample 19ET034). 
Mcq CHLORITIC QUARTZITE (MISSISSIPPIAN-DEVONIAN)_As described by Solie and others (2019) at the better exposures available outside of our map area, this unit comprises a very-fine- to finegrained, massive to laminated quartzite, in shades of pale to dark greens, grays, and browns, with variable chlorite, biotite, and/or white mica content. Locally contains a few percent of slightly coarser-grained, rounded quartz grains (referred to as grit). Magnetic susceptibility is generally moderately low, averaging $0.72 \times 10^{-3} \mathrm{SI}$, ranging from $0.01 \times 10^{-3}$ to $13.1 \times 10^{-3} \mathrm{SI}$; quartzite with highest values contains magnetite. Mississippian or older age assignment is based on similar metamorphic facies and apparent stratigraphic association with and/or beneath unit Ms (Solie and others, 2019) and MDmr (this map).

\section{Parautochthonous amphibolite-facies metamorphic rocks of Lake George assemblage}

Amphibolite-facies gneiss and schist of the Lake George assemblage occupies the lowest structural level in the map area. The metasedimentary lithologies were deposited prior to the intrusion of Mississippian-Devonian granitic plutons (MDag) and may be the metamorphosed equivalents of the Neoproterozoic-Devonian passive margin strata of the Selwyn Basin. The rocks were metamorphosed to upper amphibolite facies (see chapter B) prior to cooling through ${ }^{40} \mathrm{Ar} /{ }^{39} \mathrm{Ar}$ closure temperatures in the Early Cretaceous (table 3; Pavlis and others, 1993; Dusel-Bacon and others, 2002; Jones and Benowitz, 2020; Naibert and others, 2020)

MDag DIVIDE MOUNTAIN AUGEN GNEISS (EARLY MISSISSIPPIAN-LATE DEVONIAN)_Homogeneous unit of deformed, megacrystic orthogneiss with plutonic protoliths including granite and, locally, granodiorite. This unit is distinguished by its characteristic alkali-feldspar augen porphyroclasts, typically 3 to $8 \mathrm{~mm}$ and locally up to $5 \mathrm{~cm}$ long. Gneissic matrix is fine- to medium-grained, and its mineralogy includes: alkali feldspar, $0.5-3 \mathrm{~mm}$, sub- to anhedral (30-45 percent), typically replaced by sericite; plagioclase, $0.5-3 \mathrm{~mm}$, anhedral (15-20 percent), strong weathering and typically replaced by sericite; quartz, $0.1-0.5 \mathrm{~mm}$, granoblastic (20-45 percent), sweeping and undulatory extinction, irregular grain boundaries and subgrains; biotite, $1-3 \mathrm{~mm}$ long (5-15 percent), defines moderate foliation, varying degrees of chlorite replacement; muscovite, $0.2-0.5 \mathrm{~mm}$ long (3-10 percent), aligned in foliation. The biotite and muscovite often form foliation-parallel, sub-mm bands which separate other felsic layers. Minor minerals include epidote, chlorite, oxides, relict garnets, and zircon. Average magnetic susceptibility is $0.85 \times 10^{-3} \mathrm{SI}$. This unit has a medium- to coarse-grained granitic protolith that is preserved locally; in one outcrop we observed the transition from minimally strained granite into augen orthogneiss dated at $367.6 \pm 8.4$ and $360.7 \pm$ 8.7 Ma, respectively (U-Pb zircon, samples 19SPR174 and 19ADW351C [table 1; Wildland and others, 2021]). Todd and others (2019) obtained a U-Pb zircon age of $355.0 \pm 4.5 \mathrm{Ma}$ from augen orthogneiss in the Divide Mountain area in the Tanacross D-1 Quadrangle. Dusel-Bacon and Williams (2009) reported $\mathrm{U}-\mathrm{Pb}$ zircon ages for four different samples of augen gneiss from this unit outside of our map area, west of Divide Mountain, that yielded ages ranging from $350.4 \pm 5.6 \mathrm{Ma}$ to $370.5 \pm 5.9 \mathrm{Ma}$.

MDIo ORTHOGNEISS (EARLY MISSISSIPPIAN-LATE DEVONIAN)_Fine-grained, weakly to moderately foliated orthogneiss of granodiorite to granite composition, locally mylonitic or schistose. Mineralogy includes: alkali feldspar, $0.5-1 \mathrm{~mm}$ (20-55 percent), often stretched or rotated, twinning common, inclusion-rich, typically replaced by sericite; plagioclase, $0.2-0.5 \mathrm{~mm}$, subhedral (25-40 percent), polysynthetic twinning, sericite replacement common; quartz, $0.2-2 \mathrm{~mm}$ (25-45 percent), undulatory extinction, dynamic recrystallization with subgrains or neograins; biotite, $0.5-2 \mathrm{~mm}$ long (5-15 percent), defining foliation, typically fresh crystals with local chlorite replacement; muscovite, $0.5-2 \mathrm{~mm}$ long (up to 15 percent), defining foliation; and locally, hornblende, subhedral to amorphous clots, aligned in fabric, rims locally show chlorite alteration (5-20 percent). Minor minerals include less than 2 percent garnet, chlorite, 
epidote, pyrite, zircon, apatite. Average magnetic susceptibility is $1.59 \times 10^{-3} \mathrm{SI}$. A leucogranite orthogneiss yielded a U-Pb zircon crystallization age of $370.6 \pm 8.3 \mathrm{Ma}$ (sample 19ADW202; Wildland and others, 2021). In the adjacent Northeast Tanacross geologic map (Wypych and others, 2021), orthogneiss yielded a U-Pb zircon age of $370.6 \pm 9.6 \mathrm{Ma}$ (sample 17JEA001; Todd and others, 2019). This unit correlates to the Lake George orthogneiss (unit MDlo) of Wypych and others (2021) and Solie and others (2019).

MDla AMPHIBOLITE (MISSISSIPPIAN-DEVONIAN)_An amphibolite-facies unit, consisting mostly of metamafic rocks, but also including meta-intermediate and rare meta-ultramafic rocks, that sporadically occurs throughout the Lake George assemblage. Fine- to medium-grained, schistose hornblende amphibolite (commonly with a partial, greenschist-facies overprint) is the predominant rock type. Mineralogy is 50-70 percent hornblende (commonly with actinolite cores and [or] rims, $0.3-2 \mathrm{~mm}$ ), 15-35 percent plagioclase $\left(\mathrm{An}_{25-95}\right.$, but commonly with albite cores and (or) rims; $0.2-1.5 \mathrm{~mm}$; see chapter $\left.\mathrm{B}\right), 0.5-3$ percent titanite (subhedral, $0.1-0.3 \mathrm{~mm}$ ), $0-5$ percent biotite (typically with some alteration to chlorite, 0.02-0.5 mm), 0-5 percent chlorite (includes both subhedral and replacement, $0.2-0.5 \mathrm{~mm}$ ), 0-5 percent subhedral epidote $(0.3-0.7 \mathrm{~mm}), 0.1-1.5$ percent magnetite $(0.05-0.1 \mathrm{~mm}), 0-5$ percent quartz $(0.1-0.3$ $\mathrm{mm}), 0-7$ percent diopside $(0.3-0.5 \mathrm{~mm})$, and $0-5$ percent calcic almandine $(0.5-1 \mathrm{~mm})$. Diopside and garnet-bearing amphibolite is apparently restricted to the northeast part of the map area. Rare meta-ultramafic rock contains $10-40$ percent (retrograde) serpentine and some combination of forsterite-rich olivine, anthophyllite, diopside, tremolite, chlorite, Cr-magnetite, and dolomite (determined by microprobe). Meta-intermediate rock contains more quartz and less amphibole than metamafic rock. Magnetic susceptibility is variable, $0.06-75 \times 10^{-3} \mathrm{SI}$, averaging $3.6 \times 10^{-3} \mathrm{SI}$, reflecting the variable rock types present in the unit. There is no conclusive evidence that distinguishes between a volcanic versus intrusive origin for this unit. The age is constrained by a sample of Lake George amphibolite in the adjacent Northeast Tanacross geologic map dated at $351.5 \pm 4.3 \mathrm{Ma}$ by U-Pb zircon (Wypych and others, 2020).

MDIgs METASEDIMENTARY ROCKS (MISSISSIPPIAN TO PROTEROZOIC)—Composite unit composed of amphibolite-facies paragneiss and interlayered with lesser quartzite, schist, and orthogneiss. Paragneiss is fine- to medium-grained, moderate to strongly foliated, and gneissic to locally schistose. Modal mineralogy includes: quartz, fine-grained, $0.2-2 \mathrm{~mm}$ (40-70 percent), undulatory extinction, irregular grain boundaries, and forms thin sub-mm layers; alkali feldspar, $0.5-2 \mathrm{~mm}$ (20-25 percent), is twinned, forms bands, commonly replaced by sericite; plagioclase, $0.5-1 \mathrm{~mm}$ (10-20 percent), local polysynthetic twinning, weathered; biotite, $0.5-1 \mathrm{~mm}$ (10-30 percent), well-aligned in foliation, fresh looking, forms 1 -mm thick layers; muscovite, very fine-grained (minor, less than 5 percent), found as inclusions in alkali-feldspar observed to be normal to the fabric. The average magnetic susceptibility of the paragneiss is 1.68 x $10^{-3}$ SI. Quartzites are very fine- to fine-grained, locally have lineation defined by muscovite, contain up to 2 percent magnetite and gritty quartz grains. The median magnetic susceptibility of the quartzite is 0.27 $\times 10^{-3} \mathrm{SI}$, but where magnetite is found can be up to $13.8 \times 10^{-3} \mathrm{SI}$. The only age constraint on this unit is that it is the country rock into which Late Devonian to Early Mississippian plutons (unit MDag) intruded; it likely comprises the metamorphic equivalents of Neoproterozoic through Devonian Selwyn Basin lithologies. This unit can be correlated to the Lake George paragneiss (MDlp) of Wypych and others (2021).

MPgq GRITTY QUARTZITE (MISSISSIPPIAN OR OLDER)—As described by Solie and others (2019) in the adjacent map, this unit comprises very-fine- to fine-grained, light- to medium-gray quartzite, characteristically with larger rounded conglomeratic quartz "grit" grains in the finer-grained matrix. White mica \pm biotite content varies; rarely slightly calcareous. Unit also includes minor interlayered white mica-biotite-quartz schist \pm chlorite. Based on fine grain size, common biotite, rare garnet, and relative paucity of chlorite and epidote, unit is interpreted as lower amphibolite facies. Magnetic susceptibility is generally low, averaging $0.11 \times 10^{-3} \mathrm{SI}$, ranging from $0.01 \times 10^{-3}$ to $0.60 \times 10^{-3} \mathrm{SI}$. This unit is the same as unit DEgq of Solie and others (2019). 


\section{ACKNOWLEDGMENTS}

Cynthia Dusel-Bacon and Doug C. Kreiner reviewed the manuscript and provided constructive feedback for which we are most grateful. We also thank J.V. "Jamey” Jones III for ongoing geological discussions and informal reviews.

Donald L. Stevens and David A. Hedderly-Smith shared data and knowledge of the area. Charles G. "Chip" Ireys oriented us to the Moosehorn area, and we also thank him for his hospitality during our three-week stay at his camp. Thanks to Keith Warren and Aurora Aviation for helicopter support, 40-Mile Air for logistical support, and to the Alaska Fire Service for their efforts protecting our camp during the 2019 McArthur Creek fire.

\section{REFERENCES CITED}

AERODAT, 1977, Airborne Electromagnetic Survey Profiles of the Taurus Area: Geophysical survey report to Cities Service Minerals Corporation. (Held by D.L. Stevens, Anchorage, Alaska)

Allan, M.M., Mortensen, J.K., Hart, C.R, Bailey, L.A., Sanchez, M.G., Ciolkiewicz, Wiltold, McKenzie, G.G., and Creaser, R.A., 2013, Magmatic and metallogenic framework of west-central Yukon and eastern Alaska, in Colpron, Maurice, Bissig, Thomas, Rusk, B.G., and Thompson, J.F.H., Tectonics, Metallogeny, and Discovery: The North American Cordillera and Similar Accretionary Settings, Society of Economic Geologists, Special Publication 17, p. 111-168.

Bacon, C.R., Dusel-Bacon, Cynthia, Aleinikoff, J.N., and Slack, J.F., 2014, The Late Cretaceous Middle Fork caldera, its resurgent intrusion, and enduring landscape stability in east-central Alaska: Geosphere, v. 10, p. 1,432-1,455.

Bacon, C.R., Foster, H.L., and Smith, J.G., 1990, Rhyolitic calderas of the Yukon-Tanana terrane, east-central Alaska; Volcanic remnants of a mid-Cretaceous magmatic arc: Journal of Geophysical Research, v. 95, no. B13, p. 21,451-21,461.

Beranek, L.P., and Mortensen, J.K., 2011, The timing and provenance record of the Late Permian Klondike orogeny in northwestern Canada and arc-continent collision along western North
We are grateful to have had access to Doyon Limited lands within the study area, and we thank Doyon Vice President of Lands Jamie Marunde and consulting geologist Harold J. Noyes for their help in securing this permission.

This project was jointly funded by the State of Alaska and the U.S. Geological Survey's Earth Mapping Resources Initiative (Earth MRI) through cooperative agreement G19AC00262. The views and conclusions contained in this document are those of the authors and should not be interpreted as representing the opinions or policies of the U.S. Geological Survey. Mention of trade names or commercial products does not constitute their endorsement by the U.S. Geological Survey.

America: Tectonics, v. 30, no. 5, p. 1-23.

Burns, L.E., Graham, G.R.C., Barefoot, J.D., Naibert, T.J., Fugro Airborne Surveys Corp., and Fugro GeoServices, Inc., 2020a, Ladue electromagnetic and magnetic airborne geophysical survey data compilation: Alaska Division of Geological \& Geophysical Surveys Geophysical Report 2019-20, 15 p. https://doi.org/10.14509/30261

Burns, L.E., Graham, G.E., Emond, A.M., Stevens Exploration Management Corp., and Fugro Airborne Surveys, 2020b, Alaska Highway corridor electromagnetic and magnetic airborne geophysical survey data compilation: Alaska Division of Geological \& Geophysical Surveys Geophysical Report 2020-15, 17 p. https://doi. org/10.14509/30462

Cities Service Minerals Corporation, 1980, Data Compilation, Cities Service Company Prospects, Tanacross Quadrangle, Alaska: Unpublished report, 19 p. (Held by D.L. Stevens, Anchorage, Alaska)

Cockfield, W.E., 1921, Sixtymile and Ladue Rivers area, Yukon: Canada Geological Survey Memoir 123, n. 105, 60 p.

Colpron, Maurice, Nelson, J.L., and Murphy, D.C., 2006, A tectonostratigraphic framework for the pericratonic terranes of the northern $\mathrm{Ca}$ nadian Cordillera, in Colpron, Maurice, and Nelson, J.L., eds., Paleozoic evolution and me- 
tallogeny of pericratonic terranes at the ancient Pacific margin of North America, Canadian and Alaskan Cordillera: Geological Association of Canada Special Paper, v. 45, p. 1-23.

Dashevsky, S.S., Schaefer, C.F., and Hunter, E.N., 2003, Bedrock geologic map of the Delta mineral belt, Tok mining district, Alaska: Alaska Division of Geological \& Geophysical Surveys Professional Report 122, 122 p., 2 sheets, scale 1:63,360. https://doi.org/10.14509/2923

Day, W.C., O'Neill, J.M., Dusel-Bacon, Cynthia, Aleinikoff, J.N., and Siron, C.R., 2014, Geologic map of the Kechumstuk fault zone in the Mount Veta area, Fortymile mining district, east-central Alaska: U.S. Geological Survey Scientific Investigations Map 3291, 1 sheet, scale 1:63,360.

Dilworth, K.M., 2003, Geological setting, nature and evolution of reduced intrusions and gold-bearing quartz veins of the 4021 prospect, Goodpaster district, east-central Alaska: Vancouver, British Columbia, Canada, University of British Columbia, M.S. thesis, 192 p.

Dusel-Bacon, Cynthia, and Aleinikoff, J.N., 1985, Petrology and tectonic significance of augen gneiss from a belt of Mississippian granitoids in the Yukon-Tanana terrane, east-central Alaska: Geological Society of America Bulletin, v. 96, no. 4, p. 411-425.

1996, U-Pb zircon and titanite ages for augen gneiss from the Divide Mountain area, eastern Yukon-Tanana Upland, Alaska, and evidence for the composite nature of the Fiftymile Batholith, in Moore, T.E., and Dumoulin, J.A., eds., Geologic studies in Alaska by the U.S. Geological Survey, 1994: U.S. Geological Survey Bulletin 2152, p. 131-141.

Dusel-Bacon, Cynthia, Aleinikoff, J.N., Day, W.C., and Mortensen, J.K., 2015, Mesozoic magmatism and timing of epigenetic $\mathrm{Pb}-\mathrm{Zn}-\mathrm{Ag}$ mineralization in the western Fortymile mining district, east-central Alaska: Zircon U-Pb geochronology, whole-rock geochemistry, and $\mathrm{Pb}$ isotopes: Geosphere, v. 11, no. 3. https://doi. org/10.1130/GES01092.1

Dusel-Bacon, Cynthia, Day, W.C., and Aleinikoff, J.N., 2013, Geochemistry, petrography, and zir- con U-Pb geochronology of Paleozoic metaigneous rocks in the Mount Veta area of east-central Alaska: implications for the evolution of the westernmost part of the Yukon-Tanana terrane: Canadian Journal of Earth Sciences, v. 50, p. 826-846. Dusel-Bacon, Cynthia, Holm-Denoma, C.S., Jones III, J.V., Aleinikoff, J.N., and Mortensen, J.K., 2017, Detrital zircon geochronology of quartzose metasedimentary rocks from parautochthonous North America, east-central Alaska: Lithosphere, v. 9, no. 6, p. 927-952. https://doi.org/10.1130/ L672.1

Dusel-Bacon, Cynthia, Hopkins, M.J., Mortensen, J.K., Dashevsky, S.S., Bressler, J.R., Day, W.C., 2006, Paleozoic tectonic and metallogenic evolution of the pericratonic rocks of east-central Alaska and adjacent Yukon Territory: Paleozoic Evolution and Metallogeny of Pericratonic Terranes at the Ancient Pacific Margin of North America, Canadian and Alaskan Cordillera, in Colpron, Maurice and Nelson, J.L., eds., Geological Association of Canada Special Paper 45, p. 25-74.

Dusel-Bacon, Cynthia, Lanphere, M.A., Sharp, W.D., Layer, P.W., and Hanson, V.L., 2002, Mesozoic thermal history and timing of structural events for the Yukon-Tanana Upland, east-central Alaska - ${ }^{40} \mathrm{Ar} /{ }^{39} \mathrm{Ar}$ data from metamorphic and plutonic rocks: Canadian Journal of Earth Sciences, v. 39, no. 6, p. 1,013-1,051.

Dusel-Bacon, Cynthia, and Williams, I.S., 2009, Zircon U-Pb evidence for prolonged mid-Paleozoic plutonism and the ages of crustal sources in east-central Alaska: Canadian Journal of Earth Sciences, v. 46, p. 21-39.

Emond, A.M., Saltus, R.W., Graham, Gina, and Goldak Airborne Surveys, 2015, Airborne magnetic geophysical survey of the Tanacross region, Alaska: Alaska Division of Geological \& Geophysical Surveys Geophysical Report 20156. https://doi.org/10.14509/29514

Flanigan, Brian, Freeman, C.J., Newberry, R.J., McCoy, D.T., Hart, C.R., 2000, Exploration models for mid and late Cretaceous intrusion-related gold deposits in Alaska and the Yukon Territory, Canada, in Geology and Ore Deposits 2000: The Great Basin and Beyond, Program 
with Abstracts, Geological Society of Nevada Symposium 2000, Reno, May 2000, p. 47-48.

Foster, H.L., 1967, Geology of the Mount Fairplay area, Alaska: U.S. Geological Survey Bulletin 1241-B, p. B1-B18, 1 sheet, scale 1:63,360.

1970, Reconnaissance geologic map of the Tanacross Quadrangle, Alaska: U.S. Geological Survey Miscellaneous Geologic Investigations Map 593, 1 sheet, scale 1:250,000.

Foster, H.L., Albert, N.R.D., Barnes, D.F., Curtin, G.C., Griscom, Andrew, Singer, D.A., and Smith, J.G., 1976, The Alaskan Mineral Resource Assessment Program; background information to accompany folio of geologic and mineral resource maps of the Tanacross Quadrangle, Alaska: U.S. Geological Survey Circular 734, 19 p.

Foster, H.L., and Igarashi, Yaeko, 1990, Fossil pollen from nonmarine sedimentary rocks of the eastern Yukon-Tanana region, east-central Alaska, in Dover, J.H., and Galloway, J.P., eds., Geologic studies in Alaska by the U.S. Geological Survey, 1989: U.S. Geological Survey Bulletin 1946, p. 11-20.

Foster, H.L., Keith, T.E.C., and Menzie, W.D., 1994, Geology of the Yukon-Tanana area of east-central Alaska, in Plafker, George, and Berg, H.C., eds., The Geology of Alaska: Geological Society of America, p. 205-240.

Gordey, S.P., and Ryan, J.J., 2005, Geology, Stewart River Area (115 N, 115-O and part of 115-J), Yukon Territory: Geological Survey of Canada Open File 4970, 1 sheet, scale 1:250,000.

Hansen, V.L., and Dusel-Bacon, Cynthia, 1998, Structural and kinematic evolution of the $\mathrm{Yu}$ kon-Tanana Upland tectonites, east-central Alaska-A record of late Paleozoic to Mesozoic crustal assembly: Geological Society of America Bulletin v. 110, no. 2, p. 211-230.

Hansen, V.L., Heizler, M.T., and Harrison, T.M., 1991, Mesozoic thermal evolution of the YukonTanana composite terrane; new evidence from ${ }^{40} \mathrm{Ar} /{ }^{39} \mathrm{Ar}$ data: Tectonics, v. 10 , no. 1 , p. 51-76. Hart, C.J.R., Goldfarb, R.J., Lewis, L.L., and Mair, J.L., 2004, The Northern Cordilleran Mid-Cretaceous Plutonic Province: Ilmenite/ Magnetite-series Granitoids and Intrusion-related Mineralisation: Resource Geology, v. 54, no.
3, p. 253-280.

Jones III, J.V., and Benowitz, J.A., 2020, ${ }^{40} \mathrm{Ar} /{ }^{39} \mathrm{Ar}$ isotopic data and ages for rocks from the Yukon-Tanana upland of eastern Alaska and the northern Aleutian Range of south-central Alaska: U.S. Geological Survey data release. https://doi.org/10.5066/P96762V3

Jones III, J.V., and O'Sullivan, Paul, 2020, U-Pb isotopic data and ages of zircon, titanite, and detrital zircon from rocks from the Yukon-Tanana Upland, Alaska: U.S. Geological Survey data release. https://doi.org/10.5066/P9WWV93S

Jones III, J.V., Todd, Erin, Caine, J.S., Holm-Denoma, C.S., Ryan, J.J., and Benowitz, J.A., 2017, Late Permian (ca. 267-257 Ma) magmatism, deformation, and metamorphism and lithotectonic associations of the Ladue River unit in east-central Alaska [abs.]: Geological Society of America Abstracts with Programs, v. 49, no. 6. https://doi.org/10.1130/abs/2017AM-304170

Joyce, N.L., 2002, Geologic setting, nature, and structural evolution of intrusion-hosted Au-bearing quartz veins at the Longline occurrence, Moosehorn Range area, west-central Yukon Territory: Vancouver, Canada, University of British Columbia, unpublished Master's thesis, 199 p.

Keith, T.E.C., Foster, H.L., Foster, R.L., Post, E.V., and Lehmbeck, W.L., 1981, Geology of an alpine-type peridotite in the Mount Sorenson area, east-central Alaska: U.S. Geological Survey Professional Paper 1170-A, p. A1-A9.

Kennecott Exploration, 2019, Oreo Mountain Project Handover Memo: Unpublished report to Tubutulik Mining Company, 11 p. (Held by D.A. Hedderly-Smith, Poulsbo, Washington)

Kerin, L.J., 1976, The reconnaissance petrology of the Mt. Fairplay igneous complex: Fairbanks, Alaska, University of Alaska Fairbanks, M.S. thesis, 95 p., 5 plates, 4 sheets.

Kreiner, D.C., Jones III, J.V., Todd, Erin, Holm-Denoma, Chris, Caine, J.S., Benowitz, J.A., 2019, Links between tectonics, magmatism, and mineralization in the formation of Late Cretaceous porphyry systems in the Yukon-Tanana upland, eastern Alaska, USA: Proceedings of the 15th biennial meeting for geology applied to mineral deposits, p. 939-942. 
Lowey, G.V., and Hills, L.V., 1988, Lithofacies, petrography and environments of deposition, Tantalus Formation (Lower Cretaceous) Indian River area, West-Central Yukon, Bulletin of Canadian Petroleum Geology, v. 36, p. 296-310.

Mair, J.L., Hart, C.J.R., Stephens, J.R., 2006, Deformation history of the northwestern Selwyn Basin, Yukon, Canada: Implications for orogen evolution and mid-Cretaceous magmatism: Geological Society of America Bulletin, v. 118, p. 304-323.

Milidragovic, Dejan, Ryan, J.J., Zagorevski, Alexandre, Piercey, S.J., 2016, Geochemistry of Permian rocks of the Yukon-Tanana terrane, western Yukon: GEMS 2 Cordillera project: Geological Survey of Canada Open File 8170, 21 p.

Murphy, D.C., Mortenson, J.K., Piercey, S.J., Orchard, M.J., and Gehrels, G.E., 2006, Mid-Paleozoic to early Mesozoic tectonostratigraphic evolution of Yukon-Tanana and Slide Mountain terranes and affiliated overlap assemblages, Finlayson Lake massive sulphide district, southeastern Yukon: Paleozoic Evolution and Metallogeny of Pericratonic Terranes at the Ancient Pacific Margin of North America, Canadian and Alaskan Cordillera, in Colpron, Maurice and Nelson, J.L., eds., Geological Association of Canada Special Paper 45, p. 75-105.

Murphy, D.C., Mortensen, J.K., and van Staal, Cees, 2009, 'Windy-McKinley' terrane, western Yukon-New data bearing on its composition, age, correlation and paleotectonic settings, in Weston, L.H., Blackburn, L.R., and Lewis, L.L., eds., Yukon Exploration and Geology 2008: Yukon Geological Survey, p. 195-209.

Naibert, T.J., Benowitz, J.A., Wypych, Alicja, Sicard, K.R., and Twelker, Evan, 2018, ${ }^{40} \mathrm{Ar} /{ }^{39} \mathrm{Ar}$ data from the Tanacross D-1 and D-2, Big Delta B-4 and B-5, and Mount Hayes A-6 quadrangles, Alaska: Alaska Division of Geological \& Geophysical Surveys Raw Data File 2018-3, 15 p. https://doi.org/10.14509/30112

2020, ${ }^{40} \mathrm{Ar} /{ }^{39} \mathrm{Ar}$ data from the Tanacross D-1 and parts of the D-2, C-1, and C-2 quadrangles, Alaska: Alaska Division of Geological \& Geophysical Surveys Raw Data File 2020-12, 35 p. https://doi.org/10.14509/30466

Naibert, T.J., Wypych, Alicja, Twelker, Evan, and Benowitz, J.A., 2021, Metamorphic cooling history of the Fortymile River and Lake George assemblages from ${ }^{40} \mathrm{Ar} /{ }^{39} \mathrm{Ar}$ geochronology from the northeast Tanacross and southeast Eagle quadrangles, Alaska, in Wypych, Alicja, Northeast Tanacross geologic mapping project, Alaska: Alaska Division of Geological \& Geophysical Surveys Report of Investigation 2020-9C. https://doi.org/10.14509/30540

Nelson, J.L., Colpron, Maurice, Piercey, S.J., Dusel-Bacon, Cynthia, Murphy, D.C., and Roots, C.F., 2006, Paleozoic tectonic and metallogenetic evolution of pericratonic terranes in Yukon, northern British Columbia and eastern Alaska: Paleozoic Evolution and Metallogeny of Pericratonic Terranes at the Ancient Pacific Margin of North America, Canadian and Alaskan Cordillera, in Colpron, Maurice and Nelson, J.L., eds., Geological Association of Canada Special Paper 45, p. 323-360.

Newberry, R.J., 2020, The Mount Fairplay igneous complex: Alaska Division of Geological \& Geophysical Surveys Preliminary Interpretive Report 2020-1, 32 p. https://doi.org/10.14509/30463

Newberry, R.J., Bundtzen, T.K., Clautice, K.H., Combellick, R.A., Douglas, Tom, Laird, G.M., Liss, S.A., Pinney, D.S., Reifenstuhl, R.R., and Solie, D.N., 1996, Preliminary geologic map of the Fairbanks mining district, Alaska: Alaska Division of Geological \& Geophysical Surveys Public Data File 96-16, 17 p., 2 sheets, scale 1:63,360. https://doi.org/10.14509/1740

Nokleberg, W.J., and Aleinikoff, J.N., 1985, Summary of stratigraphy, structure, and metamorphism of Devonian igneous-arc terranes, northeastern Mount Hayes quadrangle, eastern Alaskan Range, in Bartsch-Winkler, Susan, ed., The United States Geological Survey in Alaska; accomplishments during 1984: U.S. Geological Survey Circular 967, p. 66-70.

Parsons, A.J., Coleman, M.J., Ryan, J.J., Zagorevski, Alexandre, Joyce, N.L., Gibson, H.D., Larson, K.P., 2018, Structural evolution of a crustal-scale shear zone through a decreasing 
temperature regime: The Yukon River shear zone, Yukon-Tanana terrane, Northern Cordillera: Lithosphere v. 10, p. 760-782. https://doi. org/10.1130/L724.1

Pavlis, T.L., Sisson, V.B., Foster, H.L., Nokleberg, W.J., and Plafker, George, 1993, Mid-Cretaceous extensional tectonics of the Yukon-Tanana Terrane, Trans-Alaska Crustal Transect (TACT), east-central Alaska: Tectonics, v. 12, p. 103-122. https://doi.org/10.1029/92TC00860

Piercey, S.J., and Colpron, Maurice, 2009, Composition and provenance of the Snowcap assemblage, basement to the Yukon-Tanana terrane, northern Cordillera: Implications for Cordilleran crustal growth: Geosphere, v. 5, p. 439-464. https://doi.org/10.1130/ges00505.1

Piercey, S.J., Nelson, J.L., Colpron, Maurice, Dusel-Bacon, Cynthia, Simard, R.-L. and Roots, C.F., 2006, Paleozoic magmatism and crustal recycling along the ancient Pacific margin of North America, northern Cordillera: Paleozoic Evolution and Metallogeny of Pericratonic Terranes at the Ancient Pacific Margin of North America, Canadian and Alaskan Cordillera, Colpron, in Maurice and Nelson, J.L., eds., Geological Association of Canada Special Paper 45, p. 323-360.

Ryan, J.J., Zagorevsky, Alexandre, Roots, C.F., and Joyce, N.L., 2014, Paleozoic tectonostratigraphy of the northern Stevenson Ridge area, Yukon: Geological Survey of Canada, Current Research 2014-4, 13 p. https://doi.org/10.4095/293924

Ryan, J.J., Zagorevski, Alexandre, Williams, S.P., Roots, C.F., Cioliewicz, W., Hayward, N., and Chapman, J.B., 2013, Geology, Stevenson Ridge (northwest part), Yukon: Geological Survey of Canada, Canadian Geoscience Map 117 (2nd edition, preliminary), scale 1:100,000. http:// doi.org/10.4095/292408

Sánchez, M.G., Allan, M.M., Hart, C.J., Mortensen, J.K., 2014, Extracting ore-deposit-controlling structures from aeromagnetic, gravimetric, topographic, and regional geologic data in western Yukon and eastern Alaska: Interpretation, v. 2, no. 4, p. SJ75-SJ 102.

Sicard, K.R., Naibert, T.J., Hubbard, T.D., Twelker, Evan, Wypych, Alicja, Werdon, M.B., Will- ingham, A.L., Gillis, R.J., Lande, L.L., and Newberry, R.J., 2017, Geologic map of the Tok River area, Tanacross A-5 and A-6 quadrangles, eastern Alaska Range, Alaska: Alaska Division of Geological \& Geophysical Surveys Preliminary Interpretive Report 2017-3, 15 p., 1 sheet, scale 1:63,360. https://doi.org/10.14509/29722

Solie, D.N., Layer, P.W., Werdon, M.B., Newberry, R.J., Freeman, L.K., and Lessard, R.R., 2013, ${ }^{40} \mathrm{Ar} /{ }^{39} \mathrm{Ar}$ data, Alaska Highway corridor from Delta Junction to Canada border, parts of Mount Hayes, Tanacross, and Nabesna quadrangles, Alaska: Alaska Division of Geological \& Geophysical Surveys Raw Data File 2013-8, 35 p. https://doi.org/10.14509/26841

Solie, D.N., O’Sullivan, P.B., Werdon, M.B., Freeman, L.K., Newberry, R.J., Szumigala, D.J., and Hubbard, T.D., 2014, Zircon U-Pb age data, Alaska Highway Corridor, Tanacross and Nabesna quadrangles, Alaska: Alaska Division of Geological \& Geophysical Surveys Raw Data File 2014-16, 29 p. https://doi.org/10.14509/27322 Solie, D.N., Werdon, M.B., Freeman, L.K., Newberry, R.J., Szumigala, D.J., Speeter, G.G., and Elliott, B.A., 2019, Bedrock-geologic map, Alaska Highway corridor, Tetlin Junction, Alaska to Canada border: Alaska Division of Geological \& Geophysical Surveys Preliminary Interpretive Report 2019-3, 16 p., 2 sheets, scale 1:63,360. https://doi.org/10.14509/30038

Szumigala, D.J., Newberry, R.J., Werdon, M.B., Athey, J.E., Flynn, R.L., and Clautice, K.H., 2002, Bedrock geologic map of the Eagle A-1 Quadrangle, Fortymile mining district: Alaska Division of Geological \& Geophysical Surveys Preliminary Interpretive Report 2002-1B, 1 sheet, scale 1:63,360. https://doi. org/10.14509/2864

Todd, Erin, Wypych, Alicja, and Kylander-Clark, Andrew, 2019, U-Pb and Lu-Hf isotope, age, and trace element data from zircon separates from the Tanacross D-1, and parts of D-2, C-1, and C-2 quadrangles: Alaska Division of Geological \& Geophysical Surveys Raw Data File 2019-5, 10 p. https://doi.org/10.14509/30198

Twelker, Evan, and O'Sullivan, P.B., 2021a, U-Pb 
zircon data and ages for bedrock samples from the Richardson mining district, Big Delta Quadrangle, Alaska: Alaska Division of Geological \& Geophysical Surveys Raw Data File 2020-14, 17 p. https://doi.org/10.14509/30555

2021b, U-Pb detrital zircon geochronology of Cretaceous-Cenozoic sedimentary rocks in the Ladue River-Mount Fairplay area, Alaska: Alaska Division of Geological \& Geophysical Surveys Preliminary Interpretive Report 2021-2, 16 p. https://doi.org/10.14509/30683

Wahrhaftig, Clyde, 1960, The physiographic provinces of Alaska: U.S. Geological Survey OpenFile Report 60-146, 76 p.

Werdon, M.B., Newberry, R.J., and Szumigala, D.J., 2001, Bedrock geologic map of the Eagle A-2 Quadrangle, Fortymile mining district, Alaska: Alaska Division of Geological \& Geophysical Surveys Preliminary Interpretive Report 2001-3B, 1 sheet, scale 1:63,360. https://doi. org/10.14509/2670

Wildland, A.D., Wypych, Alicja, Regan, S.P., and Holland, Mark, 2021, U-Pb zircon ages from bedrock samples collected in the Tanacross and Nabesna quadrangles, eastern Alaska: Alaska Division of Geological \& Geophysical Surveys Preliminary Interpretive Report 2021-4, 47 p. https://doi.org/10.14509/30732

Wilson, F.H., Hults, C.P., Mull, C.G., and Karl, S.M., 2015, Geologic map of Alaska: U.S. Geological Survey Scientific Investigations Map 3340, 196 p., 2 sheets, scale 1:1,584,000. https://alaska.usgs.gov/science/geology/state_ map/interactive_map/AKgeologic_map.html
Wypych, Alicja, Hubbard, T.D., Naibert, T.J., Athey, J.E., Newberry, R.J., Sicard, K.R., Twelker, Evan, Werdon, M.B., Willingham, A.L., Wyatt, W.C., and Lockett, A.C., 2021, Northeast Tanacross geologic map and map units and descriptions, in Wypych, Alicja, ed., Northeast Tanacross geologic mapping project, Alaska: Alaska Division of Geological \& Geophysical Surveys Report of Investigation 2020-9B. https://doi.org/10.14509/30539

Wypych, Alicja, Jones, J.V., III, and O'Sullivan, Paul, 2020, U-Pb zircon ages from bedrock samples collected in the Tanacross D-1, and parts of the D-2, C-1, and C-2 quadrangles, Alaska: Alaska Division of Geological \& Geophysical Surveys Preliminary Interpretive Report 2020-2, 19 p. https://doi.org/10.14509/30465

Wypych, Alicja, Twelker, Evan, Naibert, T.J., Athey, J.E., Newberry, R.J., Lopez, J.A., Regan, S.P., Sicard, K.R., Wildland, A.D., and Wyatt, W.C., 2019, Major-oxide and trace-element geochemical data from rocks collected in 2019 for the Eastern Tanacross project, Tanacross and part of Nabesna quadrangles, Alaska: Alaska Division of Geological \& Geophysical Surveys Raw Data File 2019-8, 3 p. https://doi. org/10.14509/30267

Yukon Geological Survey, 2019, Yukon Digital Bedrock Geology. www.geology.gov.yk.ca/update_yukon_bedrock_geology_map.html [accessed: 3/19/2019]

2020, Yukon Geochronology - A database of Yukon isotopic age determinations: Yukon Geological Survey.http://data.geology.gov.yk.ca/ Compilation/22 [accessed February 1, 2021] 


\title{
CHAPTER B: METAMORPHISM OF THE LADUE RIVER-MOUNT FAIRPLAY AREA
}

\author{
R.J. Newberry ${ }^{1}$ and Evan Twelker ${ }^{2}$
}

\section{INTRODUCTION}

The metamorphic rocks of the Ladue RiverMount Fairplay study area comprise several assemblages or groups of units (fig. 1) that can be distinguished based on differences in their peak metamorphic grade. These include: greenschistfacies ultramafic rocks and the rocks assigned to the Klondike assemblage; lower amphibolitefacies rocks of the Ladue River unit; and upper amphibolite-facies rocks of the Lake George assemblage and Jarvis belt. The spatial distribution of these metamorphic grade differences corresponds to the patterns observed for ${ }^{40} \mathrm{Ar} /{ }^{39} \mathrm{Ar}$ metamorphic cooling ages: the rocks of the allochthonous YukonTanana terrane (YTT; Klondike and Fortymile River, Snowcap assemblages, Ladue River unit) cooled prior to the Cretaceous (Permian through Jurassic), and rocks of parautochthonous North America (pNA; Lake George assemblage) cooled during the Early Cretaceous (Pavlis and others, 1993; Dusel-Bacon and others, 2002; Naibert and others, 2020; Jones and Benowitz, 2020).

Legend
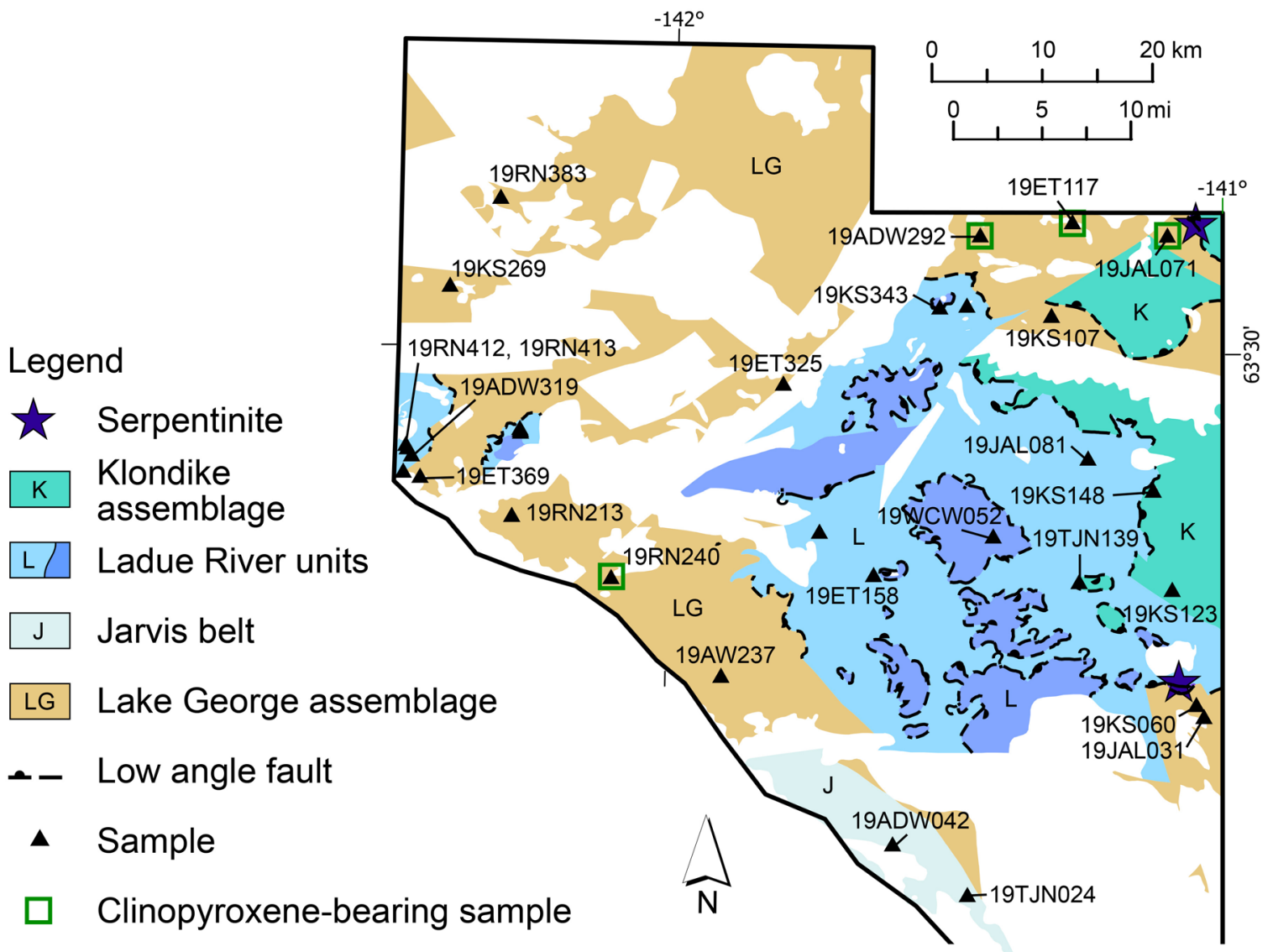

Figure 1. Map illustrating the major metamorphic assemblages of the map area and the locations of microprobeanalyzed samples.

${ }^{1}$ Department of Geosciences, University of Alaska, P.O. Box 755780, Fairbanks, Alaska 99775-5780

${ }^{2}$ Alaska Division of Geological \& Geophysical Surveys, 3354 College Rd., Fairbanks, Alaska 99709-3707 
Rocks with older metamorphic cooling ages record a metamorphic event that is older and separate from that observed in the Lake George assemblage, probably the Middle Permian-Early Triassic Klondike orogeny documented only in the allochthonous terranes (Beranek and Mortensen, 2011; van Staal and others, 2018). The higher-grade metamorphism with Early Cretaceous cooling ages reflects a later, separate event most likely related to the emplacement of the YTT over pNA, combined with the thermal effects of widespread mid-Cretaceous plutonism. The juxtaposition of older cooling ages on top of younger cooling ages indicates missing 'thermal section' and is evidence of low-angle, extensional motion on faults that separate the YTT and pNA (Pavlis and others, 1993, Hansen and Dusel-Bacon, 1998).

The purpose of this chapter is to describe the metamorphism of each map unit, specifically as it relates to the practical exercise of identifying and mapping the fundamental metamorphic assemblages in the study area. We have used thin section petrography supported by electron probe microanalyses, energy dispersive spectroscopy to identify minerals and track the compositional variations of plagioclase and hornblende, which vary with metamorphic grade. Establishing the chronology and

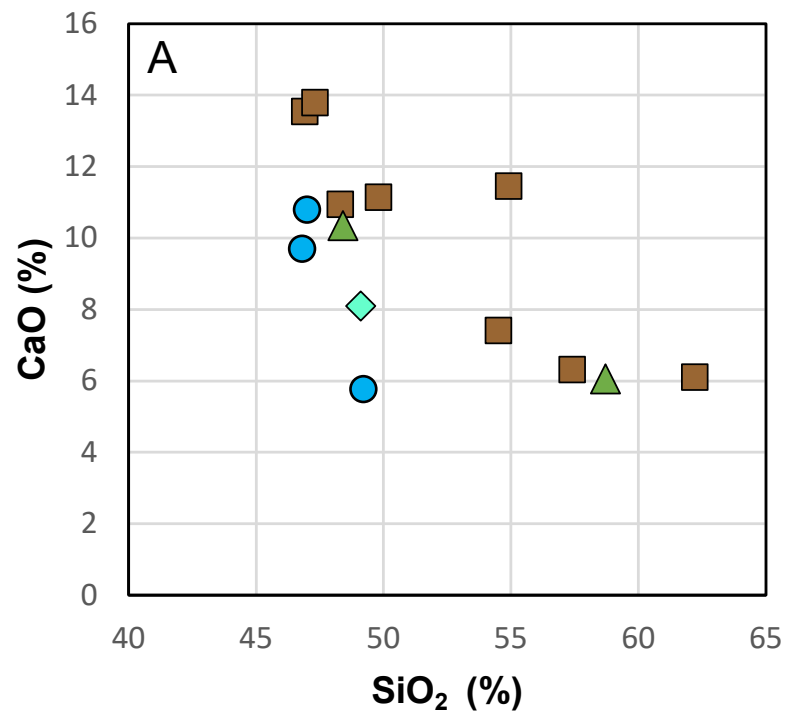

the pressure-temperature conditions of metamorphism are beyond the scope of this chapter.

\section{ANALYTICAL METHODS}

We selected metamorphic rocks of mafic composition (amphibolite, greenstone) for petrographic and electron probe microanalysis because these rocks contain metamorphic-facies-diagnostic amphiboles and plagioclase, and because they have a relatively consistent, calcium-rich composition that ensures plagioclase can equilibrate with other calcium-bearing phases. Figure 2 illustrates the major-oxide compositional similarities and differences of the map units analyzed.

R.J. Newberry analyzed plagioclase and hornblende compositions by energy-dispersive spectroscopy-electron probe microanalysis (EDS-EPMA) using the JEOL JXA-8530 Field Emission Electron Probe Microanalyzer at the University of Alaska Fairbanks Advanced Instrumentation Laboratory (UAF AIL). Analytical beam conditions were 15 $\mathrm{keV}$ and current of $45 \mathrm{nA}$. Energy dispersive spectroscopy (EDS) was undertaken using the Thermo 7 SDD-EDS System and the analyses were reported in the Thermo Scientific ${ }^{\text {тM }}$ NORAN $^{\text {тM }}$ System 7 X-Ray Microanalysis System (NSS) software. The system was calibrated using well-characterized

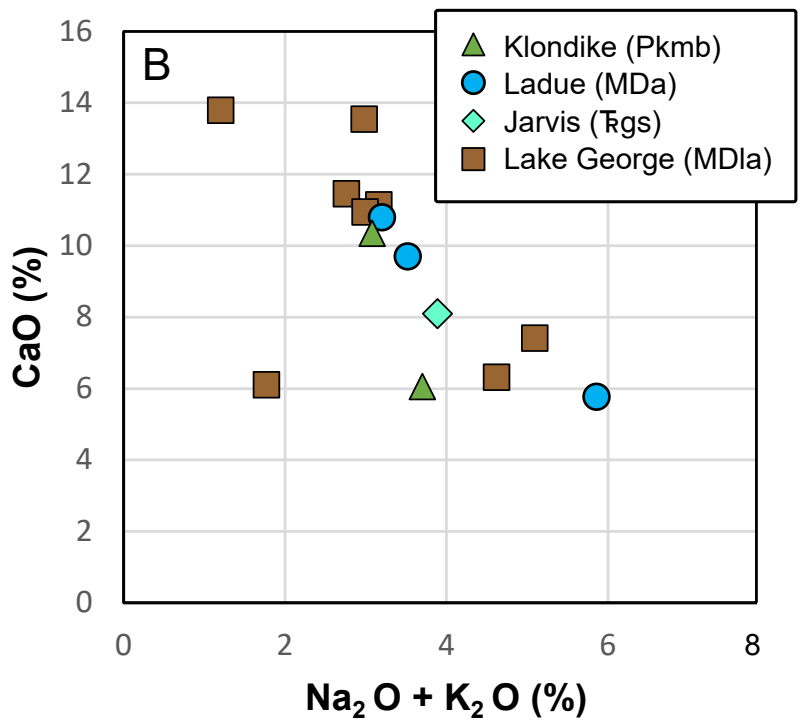

Figure 2. Bivariate scatterplots illustrating the major oxide composition of the metamafic samples analyzed by microprobe. A. $\mathrm{CaO}$ vs $\mathrm{SiO}_{2}$. B. CaO vs. $\mathrm{Na}_{2} \mathrm{O}+\mathrm{K}_{2} \mathrm{O}$. Data from Wypych and others (2019). 
natural-mineral standards as both analytical standards and analytical blanks. Count times were 60 seconds. Analyses are available in the digital data associated with this report.

\section{RESULTS}

\section{Plagioclase Compositions}

Most metamafic samples exhibit a broad range of plagioclase compositions. This unequilibrated assemblage reflects partial retrograde metamorphism (fig. 3). We interpret the high end of the percent-anorthite $(\mathrm{An})$ range to reflect remnants of peak metamorphic conditions. This offers an empirical basis for discriminating between the major metamorphic terranes in the map area based on the differences in the peak metamorphic conditions experienced by each. Plagioclase compositions above $\mathrm{An}_{30}$ are restricted to the parautochthonous Lake George amphibolite (MDla) and the Jarvis belt greenstone (kgs). Metamafic samples from the Ladue River unit contain a mix of albite and more calcic plagioclase $\left(\mathrm{An}_{1-26}\right)$, while Klondike metaba-

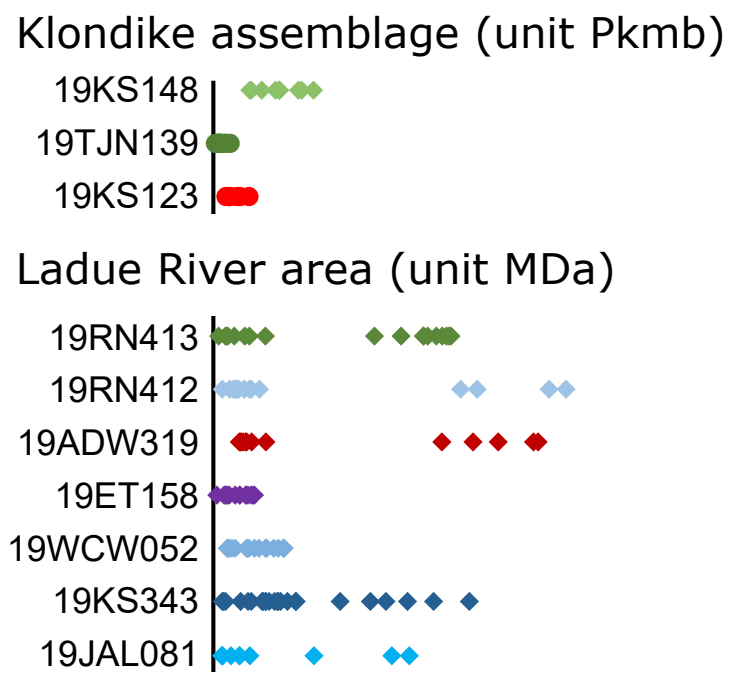

Jarvis belt (unit kgs)

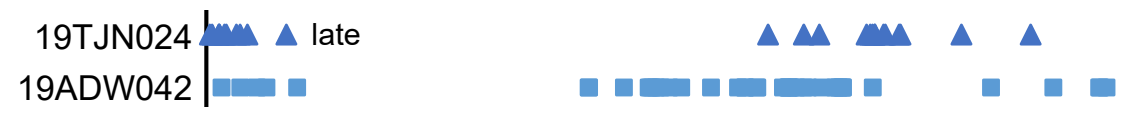

\section{Lake George assemblage (unit MDla)}

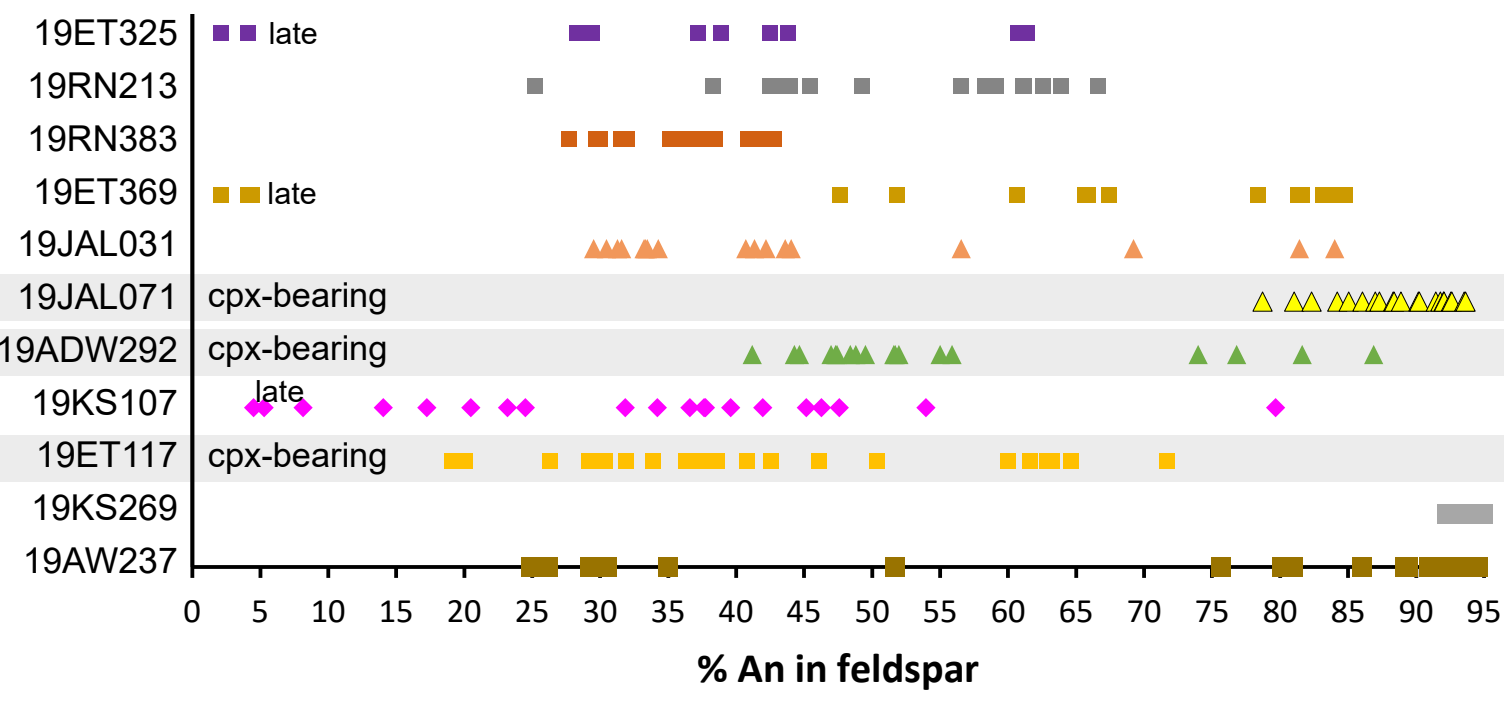

Figure 3. Plagioclase compositional data for metamafic samples (percent anorthite [An] component) based on microprobe EDS. 
site $(\mathrm{Pkmb})$ contains no plagioclase with compositions more calcic than $\mathrm{An}_{10}$ (albite).

\section{Amphibole Compositions}

The composition of "main-stage" peak-metamorphic amphibole (disregarding actinolite grain cores or retrograde overprints) in metamafic rocks also varies systematically by metamorphic terrane (fig. 4), providing a second and complementary basis for discrimination between metamorphic assemblages. Metabasite of the Klondike assemblage (Pkmb) contains only actinolite and no hornblende, whereas Ladue River unit amphibolites (MDa) contain true hornblende and/or edenite. Lake George amphibolite (MDla) and Jarvis belt greenstone ( $\mathrm{kgs}$ ) contain true hornblende, edenite, and hastingsite or parg- asite. Ladue amphibolites contain less-calcic (higher sodium $[\mathrm{Na}$ ] plus potassium $[\mathrm{K}]$ ) hornblende than those of the parautochthonous units, and their compositions are very similar to those of the allochthonous Fortymile River assemblage (fig. 4).

\section{DISCUSSION OF METAMORPHIC ASSEMBLAGES}

\section{Low-Grade Metamorphosed Ultramafic Rocks (RPum)}

Ultramafic rocks of unit $\mathrm{kP}$ zum include the low-grade metamorphic equivalents of dunite and lesser clinopyroxenite. Metamorphosed dunite (serpentinite) comprises serpentine, chlorite, dolomite, magnesite, and $\mathrm{Cr}$-magnetite; grain size is

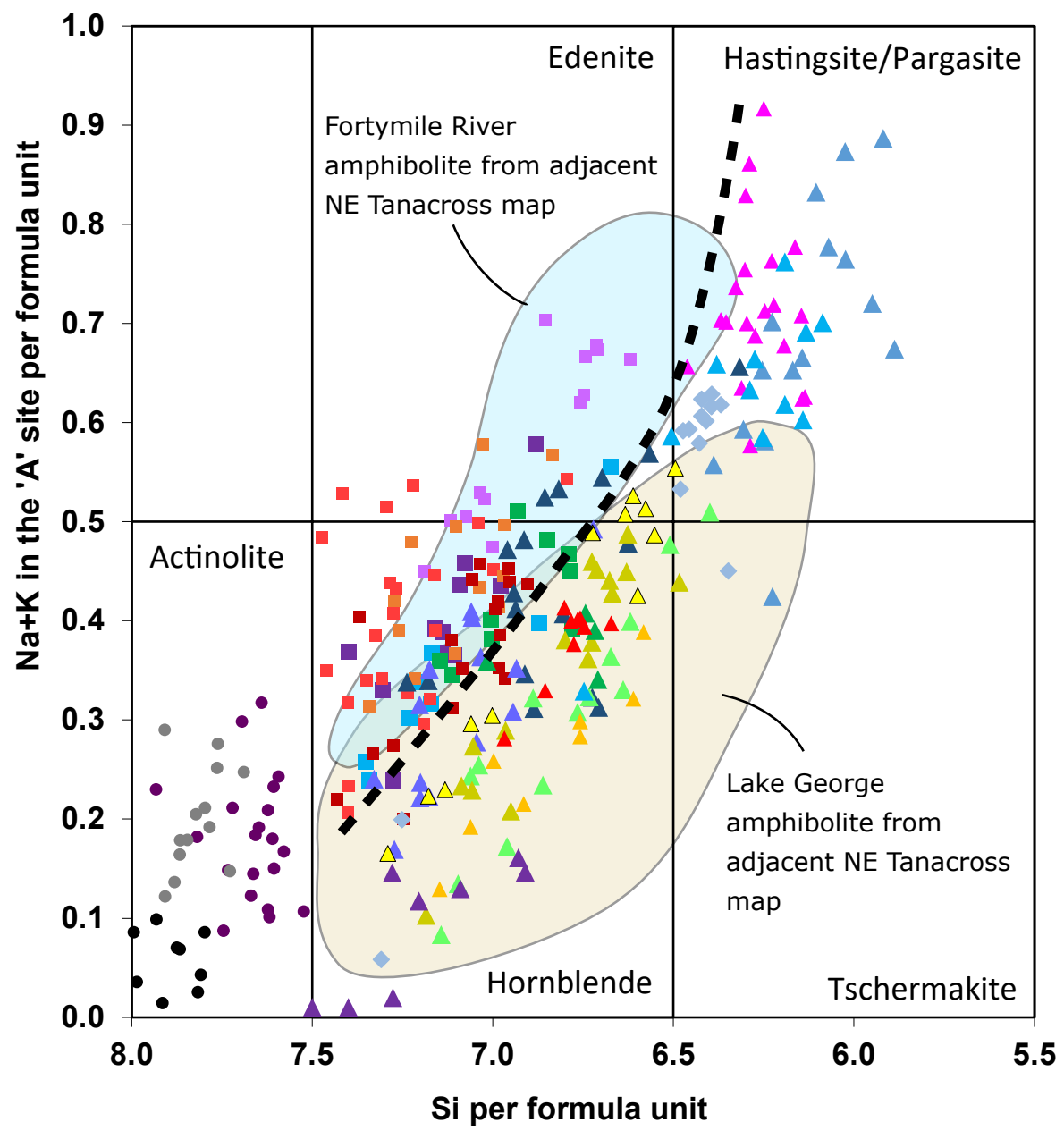

Klondike

- $19 \mathrm{KS} 148$

- 19TJN139

- 19KS123

Ladue River area

-19RN413

19RN412

19ADW319

- 19JAL081

-19KS343

- 19WCW052

-19ET158

Jarvis belt ( $\mathrm{kgs}$ )

$\triangle$ 19ADW042

$\triangle$ 19TJN024

Lake George

$\triangle 19 E T 325$

\19ET117 (cpx-bearing)

$\triangle$ 19ADW292 (cpx-bearing)

\19KS107

$\triangle$ 19JAL031

$\triangle$ 19JAL071 (cpx-bearing)

$\triangle 19 A W 237$

$\triangle 19 K S 269$

-19RN383

$\triangle 19 \mathrm{RN} 213$

$\triangle 19 E T 369$

Figure 4. Compositions of main-stage amphiboles (not including texturally late retrograde amphiboles) from metamafic samples. Fields labeled "NE Tanacross" indicate unpublished data from the Tanacross D-1 quadrangle. Data from EDS. 
very fine, 50-200 $\mu \mathrm{m}$. Metamorphosed clinopyroxenite is a tremolite-chlorite rock with lesser albite, ilmenite, and magnetite; grain size is fine, $0.2-2 \mathrm{~mm}$. Microprobe scans failed to find diagnostic indicator minerals (olivine or talc in the serpentinite; hornblende or biotite in the metaclinopyroxenite), which suggests these rocks never experienced amphibolite-facies metamorphism. We have mapped the southern locality of kPzum (near the confluence of McArthur Creek and the Ladue River) as part of the structural contact between the parautochthonous Lake George assemblage and the allochthonous rocks of the Ladue river unit, both amphibolite grade. The metaclinopyroxenite at this location must have been structurally emplaced because it never experienced amphibolite-facies metamorphism. The kPzum unit in the northeastern corner of the map separates Lake George from the overlying, allochthonous Klondike assemblage mapped in Yukon (Gordey and Ryan, 2005). The position of both ultramafic localities along the allochthon-parautochthon boundary suggests they are derived from oceanic crust of the Seventymile (Slide Mountain) terrane.

\section{Klondike Assemblage}

The Klondike assemblage includes maficto intermediate-composition greenschist ( $\mathrm{Pkmb}$ ) composed of fine-grained chlorite, actinolite, epidote, albite $\left(\mathrm{An}_{0-7}\right)$, and local quartz or biotite. Lithologies with metasedimentary or metavolcanic provenance are similarly fine-grained schists composed of quartz, white mica, chlorite, albite, epidote, and local biotite. Microprobe examination did not find relict hornblende or plagioclase. Based on these observations, we conclude that the Klondike assemblage in eastern Alaska experienced upper greenschist-facies metamorphism, but it did not experience the amphibolite-facies metamorphism that effected the other allochthonous rocks in the area.

\section{Ladue River Unit}

Amphibolite (unit MDa) is a minor constituent of the allochthonous rocks of the Ladue River unit. Prograde mineralogy includes hornblende, plagioclase $\left(\mathrm{An}_{10-25}\right)$, biotite, and phengitic muscovite; based on textural evidence, chlorite and clinozoisite may also be part of the prograde assemblage. We did not find clinopyroxene in this unit. Retrograde mineralogy includes actinolite after hornblende, albite after plagioclase, and chlorite after biotite. Metasedimentary (MPms) lithologies are siliceous and contain biotite, chloritized biotite, chlorite, and epidote-group minerals. Garnet (partially or completely replaced by chlorite) was found in several samples and seems to be more common than in the Lake George metasedimentary rocks. Combined, the mineralogy and mineral compositions (see below) indicate that the Ladue River unit experienced uppermost greenschist- to lower amphibolite-facies conditions. The metamorphic grade is lower than that experienced by the Lake George assemblage, but higher than that experienced by the Klondike assemblage in the map area.

\section{Lake George Assemblage}

Lake George assemblage amphibolites (MDla) characteristically contain hornblende, $\mathrm{An}_{25-95}$ plagioclase, and titanite; some samples contain biotite. Prograde minerals present locally include diopside and calcic almandine garnet. Microprobe examination reveals that some metamorphic hornblende retains texturally early "cores" of actinolite, and metamorphic plagioclase locally contains cores of albite. An overprinting retrograde assemblage comprises texturally late actinolite and albite, chlorite partially replacing biotite, and epidote. Lake George metasedimentary rocks (units MPIgs and Degq) are siliceous, and the contained minerals are not particularly useful as indicators of metamorphic grade. They are dominated by quartz, white mica, and biotite; rare accessory minerals include sillimanite and garnet. Based on preserved mineralogy, particularly in the amphibolites, we conclude that the Lake George assemblage rocks in the map area underwent regional peak metamorphism at upper amphibolite-facies conditions, 
followed by a partial retrograde overprint at greenschist-facies conditions.

\section{Jarvis Belt Greenschist}

Rocks of the Jarvis belt belong to parautochthonous North America (Dusel-Bacon and others, 2006). Interlayered metavolcanic rocks indicate Mississippian to Devonian depositional ages, in contrast to the Lake George assemblage where magmatism of this period occurred as plutonism, now augen orthogneiss (unit MDag). The boundary between Lake George (Macomb unit) and the Jarvis belt may be structural (Dashevsky and others, 2003) or gradational/depositional (Sicard and others, 2017). Greenstone (unit kgs) is interpreted as metamorphosed gabbroic sills. The unit is intensely retrograded to actinolite, epidote, and albite, but it nevertheless preserves remnants of "main stage" metamorphic hornblende and high-anorthite $\left(\mathrm{An}_{28-66}\right)$ plagioclase (see figs. 3 and 4). Metarhyolite (MDmr) contains fabric-forming white mica and locally, metamorphic biotite that is partially to completely chloritized. Together, this evidence suggests that the Jarvis belt rocks experienced similar, amphibolite-facies peak metamorphic conditions to the Lake George assemblage.

\section{CONCLUSIONS}

Our observations show that high-An plagioclase (greater than about $\mathrm{An}_{30}$ ) occurs only in Lake George and Jarvis belt metamafic rocks, and that Klondike assemblage metamafic rocks contain only albite and actinolite. Metamafic rocks of the Ladue River amphibolite contains plagioclase up to $\mathrm{An}_{25}$ as well as hornblende, but hornblende compo- sitions are generally distinct from those of the Lake George amphibolite. The pattern of Ladue River amphibole compositions is similar to those observed in the Fortymile River assemblage. By distinguishing allochthonous from parautochthonous terranes, our results complement the ${ }^{40} \mathrm{Ar} /{ }^{39} \mathrm{Ar}$ thermochronology approach to delineation of the metamorphic terranes of the region. They also frame additional questions for future study by highlighting similarities in peak metamorphic conditions between the Lake George assemblage and the Jarvis belt, and between the Fortymile River assemblage and the Ladue River unit. We also note a contrast in metamorphic grade between the Klondike assemblage and the underlying amphibolite-grade metamorphic rocks of the Ladue River unit; on our map we interpret this as indicating structural assembly of those units following peak metamorphism.

\section{ACKNOWLEDGMENTS}

We thank Cynthia Dusel-Bacon and Doug C. Kreiner for helpful reviews of this report. Thanks to Ken Severin and the University of Alaska Advanced Instrumentation Laboratory (UAF AIL) for use of the microprobe facilities. This project was jointly funded by the State of Alaska and the U.S. Geological Survey's Earth Mapping Resources Initiative (Earth MRI) through cooperative agreement G19AC00262. The views and conclusions contained in this document are those of the authors and should not be interpreted as representing the opinions or policies of the U.S. Geological Survey. Mention of trade names or commercial products does not constitute their endorsement by the U.S. Geological Survey. 


\section{REFERENCES}

Beranek, L.P., and Mortensen, J.K., 2011, The timing and provenance record of the Late Permian Klondike orogeny in northwestern Canada and arc-continent collision along western North America: Tectonics, v. 30, p. 1-23. https://doi. org/10.1029/2010TC002849

Dashevsky, S.S., Schaefer, C.F., and Hunter, E.N., 2003, Bedrock geologic map of the Delta mineral belt, Tok mining district, Alaska: Alaska Division of Geological \& Geophysical Surveys Professional Report 122, 122 p., 2 sheets, scale 1:63,360. https://doi.org/10.14509/2923

Dusel-Bacon, Cynthia, Lanphere, M.A., Sharp, W.D., Layer, P.W., and Hanson, V.L., 2002, Mesozoic thermal history and timing of structural events for the Yukon-Tanana Upland, east-central Alaska- ${ }^{40} \mathrm{Ar} /{ }^{39} \mathrm{Ar}$ data from metamorphic and plutonic rocks: Canadian Journal of Earth Sciences, v. 39, n. 6, p. 1,013-1,051.

Dusel-Bacon, Cynthia, Hopkins, M.J., Mortensen, J.K., Dashevsky, S.S., Bressler, J.R., and Day, W.C., 2006, Paleozoic tectonic and metallogenic evolution of the pericratonic rocks of east-central Alaska and adjacent Yukon, in Colpron, Maurice and Nelson, J.L., eds., Paleozoic evolution and metallogeny of pericratonic terranes at the ancient Pacific margin of North America, Canadian and Alaskan Cordillera: Geological Association of Canada Special Paper 45, p. 25-74.

Gordey, S.P., and Ryan, J.J., 2005, Geology, Stewart River Area (115 N, 115-O and part of 115-J), Yukon Territory: Geological Survey of Canada Open File 4970, 1 sheet, scale 1:250,000.

Hansen, V.L., and Dusel-Bacon, Cynthia, 1998, Structural and kinematic evolution of the Yukon-Tanana Upland tectonites, east-central Alaska-A record of late Paleozoic to Mesozoic crustal assembly: Geological Society of America Bulletin, v. 110, n. 2, p. 211-230.

Jones, J. V., III and Benowitz, J. A., 2020, ${ }^{40} \mathrm{Ar} /{ }^{39} \mathrm{Ar}$ isotopic data and ages for rocks from the $\mathrm{Yu}$ kon-Tanana upland of eastern Alaska and the northern Aleutian Range of south-central Alaska: U.S. Geological Survey data release, https:// doi.org/10.5066/P96762V3.

Naibert, T.J., Benowitz, J.A., Wypych, Alicja, Sicard, K.R., and Twelker, Evan, 2020, ${ }^{40} \mathrm{Ar} /{ }^{39} \mathrm{Ar}$ data from the Tanacross D-1 and parts of the D-2, C-1, and C-2 quadrangles, Alaska: Alaska Division of Geological \& Geophysical Surveys Raw Data File 2020-12, 35 p. https://doi. org/10.14509/30466

Pavlis, T.L., Sisson, V.B., Foster, H.L., Nokleberg, W.J., and Plafker, George, 1993, Mid-Cretaceous extensional tectonics of the Yukon-Tanana Terrane, Trans-Alaska Crustal Transect (TACT), east-central Alaska: Tectonics, v. 12, p. 103-122. https://doi.org/10.1029/92TC00860

Sicard, K.R., Naibert, T.J., Hubbard, T.D., Twelker, Evan, Wypych, Alicja, Werdon, M.B., Willingham, A.L., Gillis, R.J., Lande, L.L., and Newberry, R.J., 2017, Geologic map of the Tok River area, Tanacross A-5 and A-6 quadrangles, eastern Alaska Range, Alaska: Alaska Division of Geological \& Geophysical Surveys Preliminary Interpretive Report 2017-3, 15 p., 1 sheet, scale 1:63,360. https://doi.org/10.14509/29722

van Staal, C.R., Zagorevski, Alexandre, McClelland, W.C., Escayola, M.P., Ryan, J.J., Parsons, A.J., and Proenza, Joaquin, 2018, Age and setting of Permian Slide Mountain terrane ophiolitic ultramafic-mafic complexes in the Yukon: Implications for late Paleozoic-early Mesozoic tectonic models in the northern Canadian Cordillera: Tectonophysics, v. 744, p. 458-483. https://doi.org/10.1016/j.tecto.2018.07.008 Wypych, Alicja, Twelker, Evan, Naibert, T.J., Athey, J.E., Newberry, R.J., Lopez, J.A., Regan, S.P., Sicard, K.R., Wildland, A.D., and Wyatt, W.C., 2019, Major-oxide and trace-element geochemical data from rocks collected in 2019 for the Eastern Tanacross project, Tanacross and part of Nabesna quadrangles, Alaska: Alaska Division of Geological \& Geophysical Surveys Raw Data File 2019-8, 3 p. https://doi. org/10.14509/30267 


\section{CHAPTER C: REGIONAL CORRELATION OF METAMORPHIC ROCKS IN THE LADUE RIVER-MOUNT FAIRPLAY MAP AREA USING TRACE-ELEMENT GEOCHEMISTRY OF METAMAFIC ROCKS}

Travis J. Naibert ${ }^{1}$ and Alicja Wypych ${ }^{1}$

\section{INTRODUCTION}

The allochthonous Yukon-Tanana Terrane (YTT) and parautochthonous North America (pNA) share Late Devonian and older geologic histories and have similar pre-Mississippian metasedimentary units (Colpron and others, 2006). The YTT is generally interpreted as a continental fragment that was rifted from the North American margin in the Devonian to Mississippian and re-accreted to the continent in the Permian to Jurassic (Colpron and others, 2006). Similar lithologies, internal deformation within the YTT before and during collision with the continental margin, and deformation during subsequent mid-Cretaceous extension, make it difficult to correlate units regionally and to differentiate allochthonous and parautochthonous rocks.

During initial geologic mapping of the Tanacross Quadrangle, Foster (1970) identified an area of quartz-mica schist that she tentatively correlated to the Klondike Schist (Cockfield, 1921) in the adjacent Yukon. Dusel-Bacon and others (2006) obtained a Devonian $\mathrm{U}-\mathrm{Pb}$ zircon age for one sample of this unit, precluding a simple correlation of these rocks to the Permian Klondike assemblage; they named the area the "Ladue River unit" and left regional correlations to future study. U.S. Geological Survey (USGS) geologists recently obtained new U-Pb (Jones and O'Sullivan, 2020) and ${ }^{40} \mathrm{Ar} /{ }^{39} \mathrm{Ar}$ (Jones and Benowitz, 2020) geochronology data, enabling the Ladue River area to be subdivided into areas of Devonian-Mississippian and Permian magmatic ages (Jones and others, 2017). Our geochronology (Wildland and others, 2021) and mapping (Twelker and others, 2021) supports this basic subdivision.
Significant questions of regional correlation remain despite the new age control, including whether the Devonian-Mississippian Ladue River unit rocks are affiliated with the Snowcap assemblage or the Fortymile River assemblage, and whether the Permian metaigneous rocks are truly correlative with the Klondike assemblage. All of the metamorphic assemblages in the Ladue RiverMount Fairplay map area include metamorphosed mafic rocks (Newberry and Twelker, 2021; Twelker and others, 2021) and the trace element variations of metamafic rocks have been used to characterize metamorphic terranes in the region (for example, Dusel-Bacon and Cooper, 1999; Dusel-Bacon and others, 2006). In this chapter we compare trace-element geochemistry of the metamafic units to published trace-element data from eastern Alaska and Yukon to aid in correlation of regional geologic units. Mafic traceelement geochemistry can also be used to interpret tectonic environment of magmatism during protolith formation (for example, Meschede, 1986; Pearce, 2008). This chapter draws on wholerock geochemical analyses of metamafic rocks from the DGGS Eastern Tanacross project. A supplemental spreadsheet that relates map units to samples from the geochemical report used for this interpretation can be downloaded from https:// doi.org/10.14509/30739. See Wypych and others (2019; https://dggs.alaska.gov/pubs/id/30267) for full documentation of the sample collection, preparation, and analytical methods.

\section{Parautochthonous North America}

Units of pNA in the map area include the Lake George assemblage, the Divide Mountain augen gneiss, and the Jarvis belt. The Lake George assemblage

${ }^{1}$ Alaska Division of Geological \& Geophysical Surveys, 3354 College Rd., Fairbanks, Alaska 99709-3707 
and Divide Mountain augen gneiss are correlated with the adjacent Northeast Tanacross map area of Wypych and others (2021) based on field mapping. Lithologies of these units are consistent with the adjacent map area as well as with similar units described elsewhere in the Tanacross Quadrangle (Solie and others, 2019; Dusel-Bacon and others, 2002, 2006) and with the White River assemblage in western Yukon (Ryan and others, 2013). The Lake George assemblage and the Snowcap assemblage in Yukon have the same constituent lithologies, comparable amphibolite-facies metamorphic grades, and similar-age metaplutonic rocks as the above-mentioned units of pNA. Lake George assemblage rocks have Early Cretaceous ${ }^{40} \mathrm{Ar} /{ }^{39} \mathrm{Ar}$ cooling ages in eastern Alaska, whereas allochthonous amphibolite-facies units, including the Snowcap assemblage, have Triassic to Jurassic ${ }^{40} \mathrm{Ar} /{ }^{39} \mathrm{Ar}$ cooling ages (Dusel-Bacon and others, 2002; Naibert and others, 2020; Jones and Benowitz, 2020), which aided mapping in multiple locations.

Amphibolite samples from the Lake George assemblage in the Ladue River-Mount Fairplay map area and the adjacent Northeast Tanacross map area have alkali-basalt to basalt protoliths and their trace element geochemistry indicates tectonic environments ranging from volcanic arc basalts to within-plate basalts and mid-ocean-ridge basalts (MORB) (figs. 1A and E). The few published U-Pb zircon ages from Lake George amphibolites are all Late Devonian to Early Mississippian (ca. 351-365 Ma: Jones and O'Sullivan, 2020; Todd and others, 2019; and further west in the Big Delta Quadrangle, 369 Ma: Day and others, 2003; DuselBacon and others, 2004). Within-plate basalts and MORB basalts are consistent with rifting of the Laurentian margin, which is proposed during that time period by many workers (for example, Dusel-Bacon and Cooper, 1999; Dusel-Bacon and others, 2004; Colpron and others, 2006). Three episodes of Paleozoic mafic volcanism are reported in the correlative Selwyn Basin in Yukon (Mair and others, 2006) and the Lake George assemblage amphibolites may have originated during tectonic events not recorded in the available geochronology.
Correlation of the Lake George assemblage with the same unit in the Northeast Tanacross map area to the north is well supported by overlap of amphibolite trace-element geochemistry (fig. 1; Wypych and others, 2017; 2018). The Lake George samples in the Northeast Tanacross map area include a higher proportion of MORB basalts exhibiting less crustal contamination compared to those in the Ladue River-Mount Fairplay area, and the Northeast Tanacross area also includes more numerous interlayered amphibolites, which may be a result of differing proximity to eruptive centers during continental rifting. Some amphibolites from the Lake George assemblage collected from the northeastern Tanacross quadrangle from different sample localities than from those reported in Wypych and others $(2017 ; 2018)$, as well as some from the Big Delta and Healy quadrangles west and southwest of our study area, respectively, have within-plate (OIB) trace-element signatures (Dusel-Bacon and Cooper, 1999; Dusel-Bacon and others, 2004) indicative of rifting.

The Jarvis belt units in the southwest part of the map area are projected from contacts in the adjacent Alaska Highway corridor geologic map (Solie and others, 2019) and approximately correspond to the phyllite and schist unit Pa of Foster (1970). Wildland and others (2021) determined a ca. $367 \mathrm{Ma}$ U-Pb zircon age from a felsic metavolcanic sample, and Solie and others (2019) reported a $351.7 \pm 9.3 \mathrm{U}-\mathrm{Pb}$ zircon age from a similar sample. These ages and abundant interlayered quartz-rich metasediments support the correlation of units in the Ladue River-Mount Fairplay map area to the metavolcanic Jarvis belt units in the Tok River area (Sicard and others, 2017), the Delta mineral belt (Dashevsky and others, 2003), and to the White River assemblage of Ryan and others (2014). Greenstone (kgs) within the Jarvis belt units in the map area is lithologically similar to Triassic metagabbros in the Alaska Highway corridor (Solie and others, 2019), the Tok River map area (Sicard and others, 2017), and the Delta mineral belt (Dashevsky and others, 2003). Trace-element geochemistry was not 


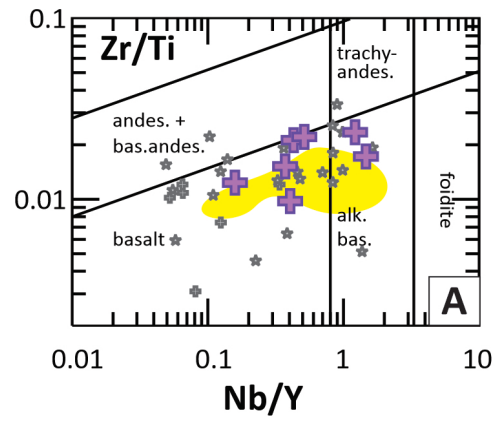

54 Lake George Assemblage amphibolite (E Tanacross map area, Wypych and others 2019)

* Lake George Assemblage amphibolite (NE Tanacross map area, Wypych and others 2017,2018)

Lake George Assemblage amphibolite (Dusel-Bacon and Cooper, 1999

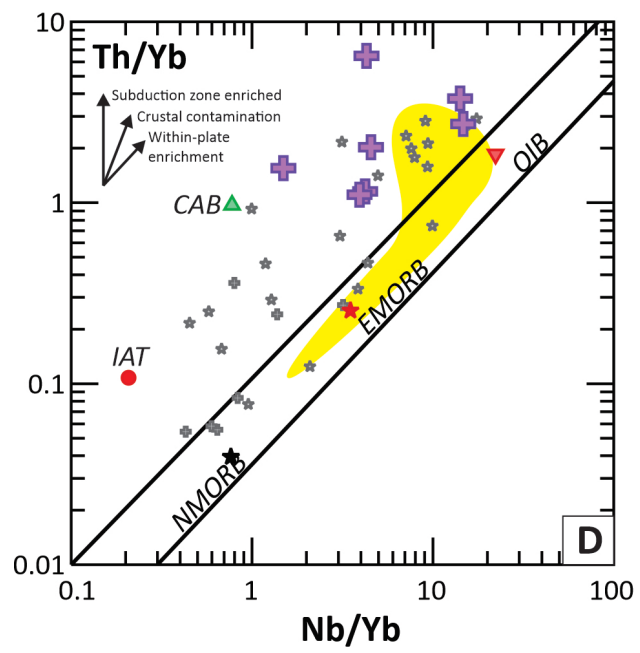

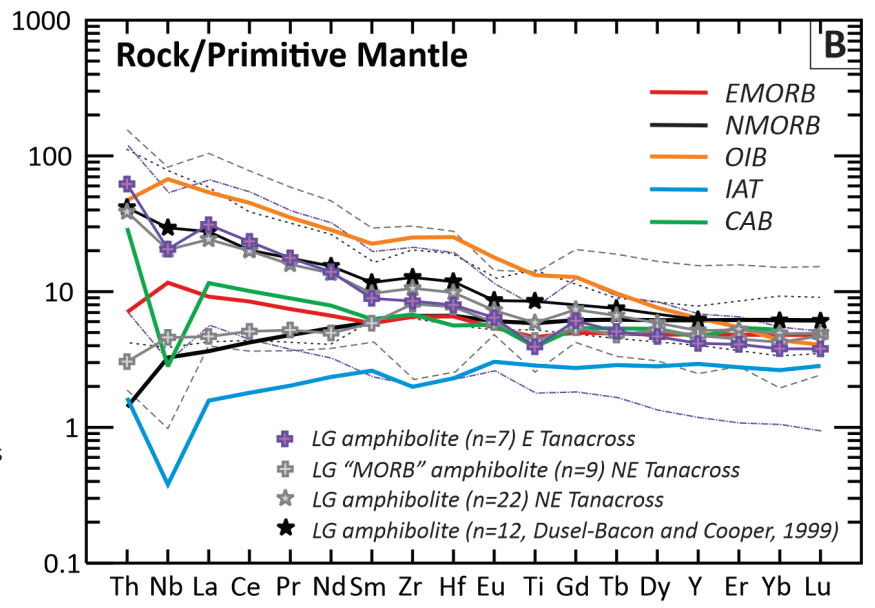

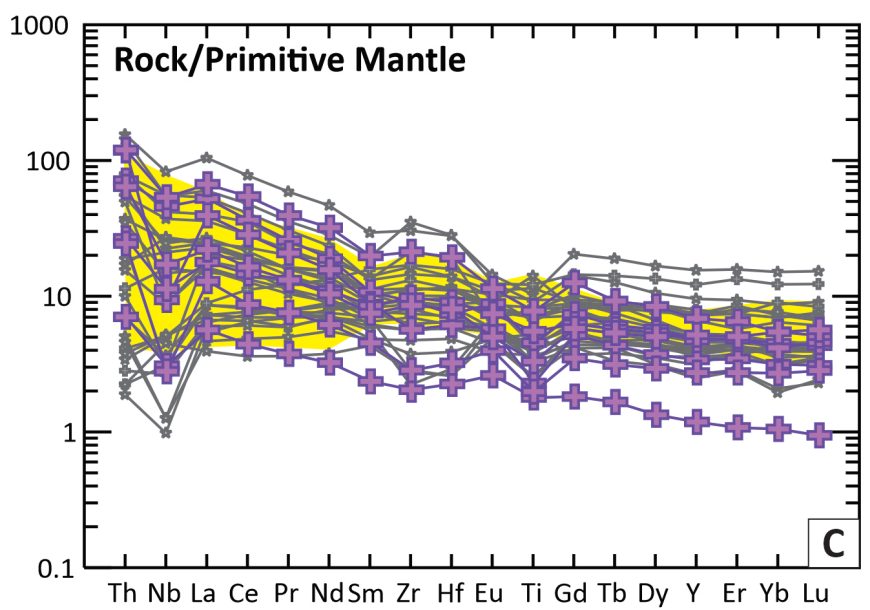

\section{Nbx2}

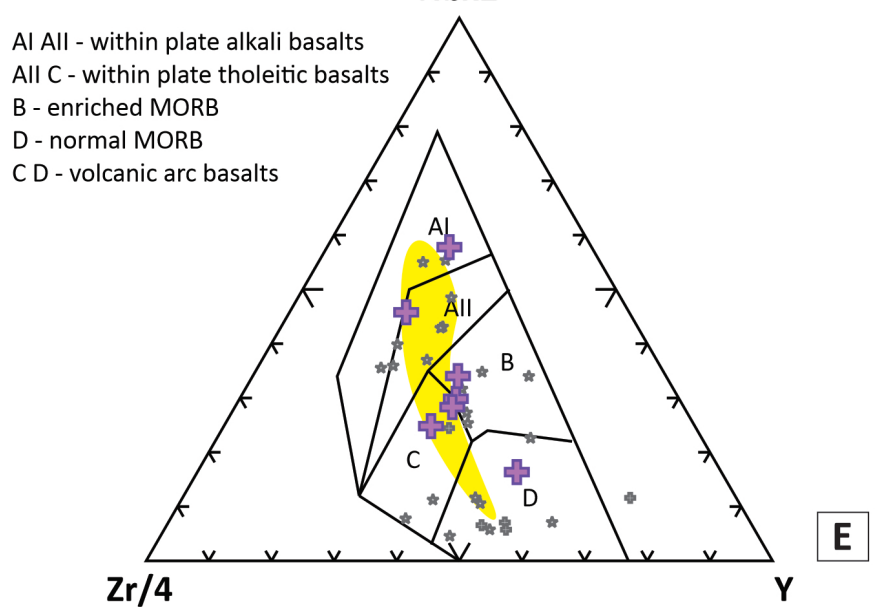

Figure 1. Trace-element geochemistry of amphibolites collected in the Lake George assemblage within the Ladue River-Mount Fairplay map area with comparison to Lake George assemblage amphibolites collected within the adjacent Northeast Tanacross map area (Wypych and others, 2017; 2018) and amphibolite samples in Dusel-Bacon and Cooper (1999). A. Magma-series discrimination diagram of Winchester and Floyd (1977). B. Primitive mantle-normalized spider diagram of Sun and McDonough (1989) with average of sample values (symbols) and sample minimums and maximums (dashed lines) compared to expected patterns from common tectonic environments. C. Primitive mantle-normalized spider diagram of Sun and McDonough (1989) with all sample values (symbols). D. Th/Yb vs. Nb/Yb basalt classification diagram of Pearce (2008). E. Nb-Zr-Y ternary diagram for basalt tectonic discrimination of Meschede (1986). 
measured from these metamafic units, but they are likely correlated with the Triassic Snag Creek suite within the White River assemblage in western Yukon based on lithology and their association with felsic metavolcanic units (Ryan and others, 2013).

\section{Allochthonous Terranes}

Allochthonous units in the Ladue RiverMount Fairplay map area include the Ladue River unit of Dusel-Bacon and others (2006), ultramafic slivers of the Seventymile Terrane, and Permian schistose units that we correlate to the Klondike Schist in Yukon. The Ladue River unit includes siliciclastic metasedimentary schist and paragneiss and interlayered metaplutonic rocks. The unit experienced amphibolite-facies metamorphism and large parts of the area have retrograde greenschist-facies mineralogy (Newberry and Twelker, 2021). Zircon U-Pb ages of metaplutonic rocks within the Ladue River unit are Late Devonian to Early Mississippian(Jones and O'Sullivan, 2020; Wildland and others, 2021) and overlap in age with metaigneous rocks of the Late Devonian Grass Lakes and the Early Mississippian Simpson Range intrusive suites within the Snowcap and Finlayson assemblages in Yukon (Yukon Geological Survey, 2020), and with both the Divide Mountain orthogneiss unit (named in this publication) in the Lake George assemblage and the older group of ages in the Fortymile River assemblage (DuselBacon and others, 2006).

Volumetrically minor amphibolite units are concordant with foliation and are interpreted as metamorphosed sills, though it is also possible that they could have mafic volcanic protoliths. One amphibolite from the map area yielded a zircon $\mathrm{U}-\mathrm{Pb}$ age of $361.8 \pm 1.6 \mathrm{Ma}$, suggesting the amphibolites are the same age as the more felsic Mississippian to Devonian metaplutonic rocks (ca. 363 Ma, Dusel-Bacon and others, 2006; ca. 371-361 Ma, Wildland and others, 2021). Trace-element geochemistry of amphibolites suggest basaltic to basaltic andesite protoliths from a volcanic arc or from within-plate tectonic environments (fig. 2).
The Ladue River unit amphibolite geochemistry overlaps the trace-element geochemistry of the Fortymile River assemblage amphibolites in the adjacent Northeast Tanacross map area and partially overlaps amphibolite trace-element geochemistry in the Snowcap (Piercey and Colpron, 2009) and Finlayson assemblages (Piercey and others, 2002) in Yukon (fig. 2).

Correlation of the Ladue River unit with the Snowcap assemblage is supported by the lack of marble layers and relative paucity of amphibolite layers in the Ladue River area. Within-plate trace element signatures from some amphibolites may reflect a continental rift setting akin to the Snowcap and Lake George assemblages. However, as clearly shown in figure $2 \mathrm{D}$, the volcanic-arc trace-element setting of the Ladue River amphibolites are similar to that for Fortymile River assemblage samples from the Northeast Tanacross map area, suggesting a likely correlation between these two units. Felsic porphyroclastic orthogneiss (MDpo) within the Ladue River unit is interpreted as metamorphosed volcanic or shallow subvolcanic rocks, which is likely further evidence of Early Mississippian Fortymile River/Finlayson arc volcanism. Orthogneiss bodies in the Ladue River unit have more granitic compositions compared to the granodiorite and tonalite compositions of orthogneisses in the Fortymile River assemblage in the Northeast Tanacross map area and in southeast Eagle Quadrangle (Werdon and others, 2001; Szumigala and others, 2002). Since deposition of the Snowcap assemblage sedimentary and volcanic layers is interpreted to transition into Finlayson deposition in some locations in Yukon (Colpron and others, 2006; Ryan and others, 2014), it is possible that the Ladue River unit also records a similar transition from rift-related siliciclastic sedimentation to the early stages of Finlayson arc volcanism. This interpretation would account for similarities to both the Snowcap and Fortymile River/Finlayson assemblages. Additionally, the Ladue River unit may represent a complex, structurally interleaved boundary between the Snowcap and Fortymile 


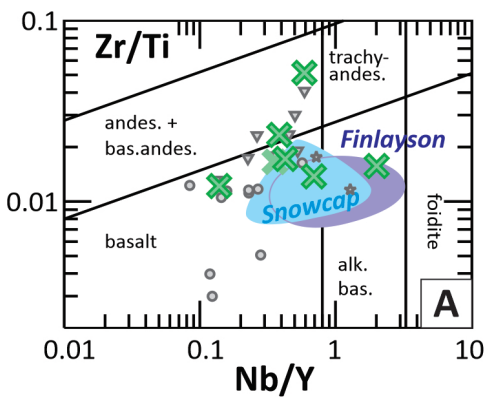

× Fortymile River Assemblage amphibolite (E Tanacross, Wypych and others 2019)

$\circ \nabla$ * Fortymile River Assemblage amphibolite (NE Tanacross map area, Wypych and others 2017, 2018) Snowcap assemblage (Piercey and Colpron, 2009)

Finlayson Lake region mafic rocks (Piercey and others, 2002)

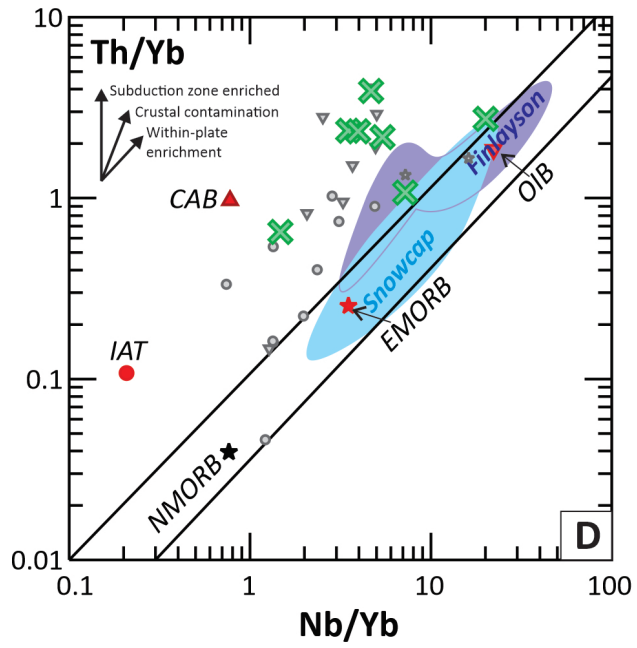

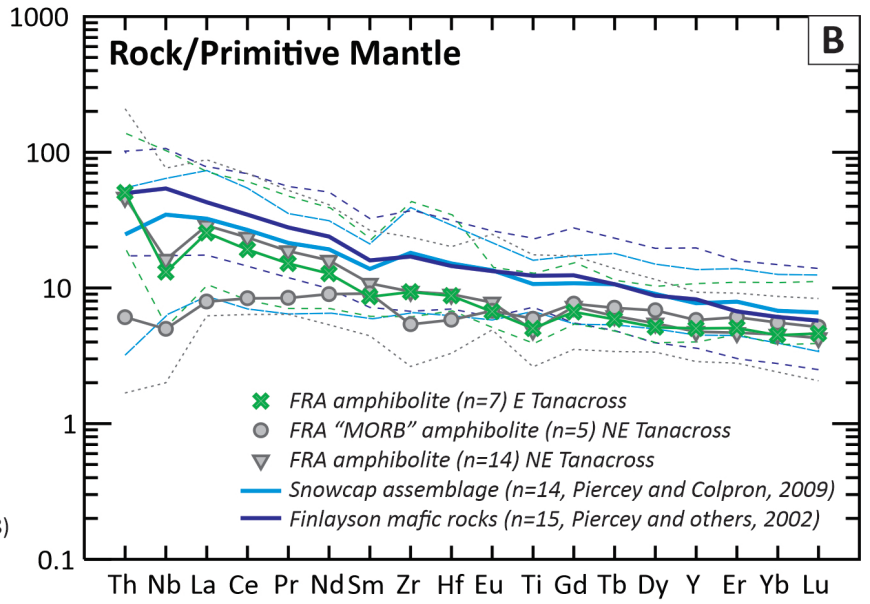

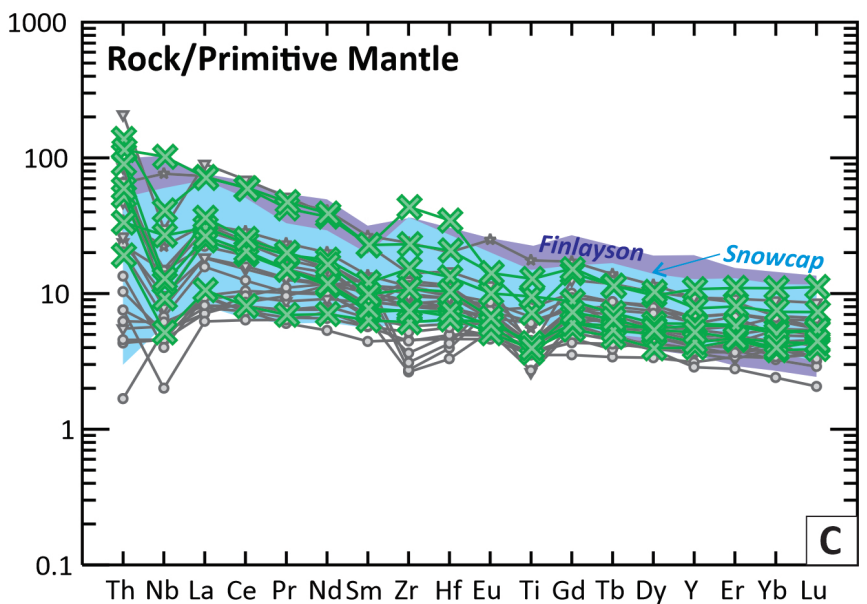

\section{Nbx2}

Al All - within plate alkali basalts All C - within plate tholeitic basalts $B$ - enriched MORB D - normal MORB C D - volcanic arc basalts

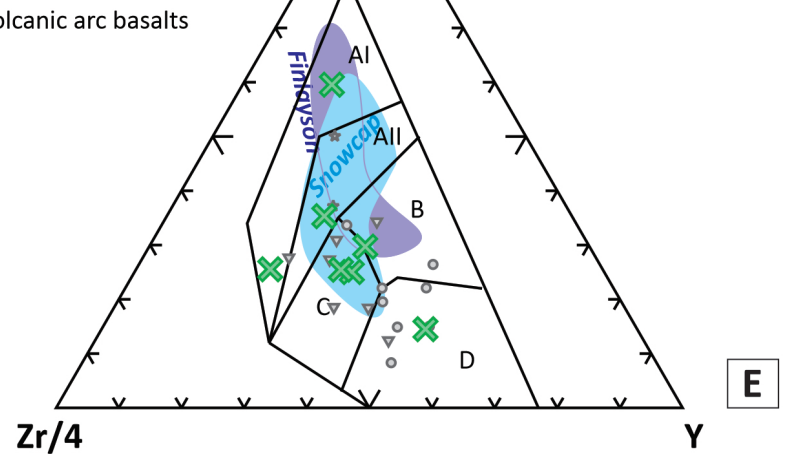

Figure 2. Trace element geochemistry of amphibolites collected in the Ladue River Unit within the Ladue River-Mount Fairplay map area with comparison to metamafic rocks of the Fortymile River assemblage in the Northeast Tanacross map area (Wypych and others, 2017; 2018) and the Finlayson and Snowcap assemblages in Yukon (Piercey and others, 2002; Piercey and Colpron, 2009). A. Magma series discrimination diagram of Winchester and Floyd (1977). B. Primitive mantle-normalized spider diagram of Sun and McDonough (1989) with average of sample values (symbols) and sample minimums and maximums (dashed lines). C. Primitive mantle-normalized spider diagram of Sun and McDonough (1989) with all sample values (symbols). D. Th/Yb vs. Nb/Yb basalt classification diagram of Pearce (2008). E. Nb-Zr-Y ternary diagram for basalt tectonic discrimination of Meschede (1986). 
River assemblages. If parts of the Ladue River area correlate to both the Snowcap and Fortymile River/ Finlayson assemblages, delineation of these internal boundaries is not possible with current data due to poor exposure.

The Permian Klondike assemblage in the Ladue River-Mount Fairplay map area includes quartz schist, white mica schist, and chlorite schist interpreted as metasedimentary rocks with minor felsic metavolcanic rocks. Interlayered greenstones and greenschists are interpreted as metamorphosed mafic volcanic rocks, although primary igneous textures are either completely overprinted by metamorphism or unrecognized due to poor exposure. Lack of outcropping contact relationships makes discrimination of basalt flows from sills impossible. These mafic metavolcanic layers are more common in our map area than they are in the dominantly felsic metavolcanic Klondike schist mapped in adjacent areas of Yukon (Beranek and Mortenson, 2011; Ryan and others, 2013). Trace-element geochemistry of the Permian metamafic rocks suggest volcanic arc basalt protoliths (fig. 3). The trace element patterns broadly overlap published data from mafic rocks of the Klondike assemblage (Milidragovic and others, 2016) and also overlaps data from mafic rocks of the Seventymile terrane (Erin Todd, U.S. Geological Survey, personal commun., 2018; Dusel-Bacon and others, 2006). The trace elements are less well matched to backarc basin basalt flows and shallow mafic intrusions in the Lower Permian Campbell Range formation of the Slide Mountain assemblage (Piercey and others, 2012), a correlative of the Seventymile terrane in the Finlayson Lake area of southeast Yukon. Zircon $\mathrm{U}-\mathrm{Pb}$ ages in the Klondike assemblage units in the map area range from 252 to $265 \mathrm{Ma}$ (Jones and O'Sullivan, 2020; Wildland and others, 2021) and, overlap with the more felsic Klondike assemblage units mapped in Yukon (Beranek and Mortenson, 2011). Additionally, the mapped greenstones do not appear to be tectonic slivers along fault zones and do not include interbedded chert as is common in the Seventymile terrane.

\section{CONCLUSIONS}

Regional correlations among the allochthonous units are complex, owing to the multiple generations of magmatism in the YTT and their protracted Paleozoic to Mesozoic deformational history. In the Eastern Tanacross map area, amphibolites and mafic-phase orthogneisses in the Ladue River unit, originally defined by Dusel-Bacon and others (2006), have trace-element geochemistry that is consistent with both volcanic-arc and back-arc magmatism. The trace-element characteristics overlap those of the Fortymile River assemblage in the northeast Tanacross Quadrangle and the correlative Finlayson assemblage in Yukon. Amphibolite trace element signatures from the Ladue River unit also partially overlap the Snowcap assemblage in Yukon and it is possible that correlatives of both the Fortymile River/Finlayson and the Snowcap assemblages are present in the Ladue River unit, either due to transitional deposition from Snowcap- to Finlayson-like protoliths during the Mississippian, or because of complex internal deformation that is unrecognized with the poor exposure in the map area.

The Permian Klondike assemblage mapped in the Ladue River-Mount Fairplay area likely correlates with the Klondike assemblage mapped in Yukon, though mafic volcanism in the Klondike arc is more widely preserved in Alaska and felsic metavolcanic rocks are more common in Yukon. Though Klondike metamafic trace elements also overlap the geochemistry of some greenstones in the Seventymile assemblage, field relationships do not suggest that these samples are from tectonic slices of seafloor as is interpreted for the Seventymile assemblage in Alaska.

Lake George assemblage map patterns, lithologies, U-Pb zircon ages, and metamafic trace-element geochemistry in the Ladue River-Mount Fairplay map area are compatible with the parautochthonous Lake George assemblage as defined elsewhere in eastern Alaska. Interlayered finergrained orthogneiss and amphibolite is character- 


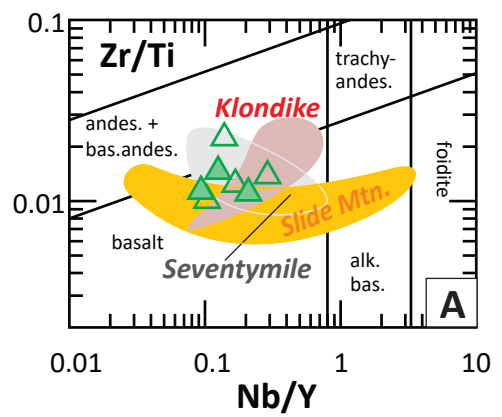

$\triangle \triangle$ Metabasite - E Tanacross (Wypych and others, 2019) Seventymile (Todd (USGS), written commun., 2018) Slide Mountain - Campbell Range Formation (Piercey and others, 2012)

Klondike mafic rocks (Milidragovic and others, 2016)
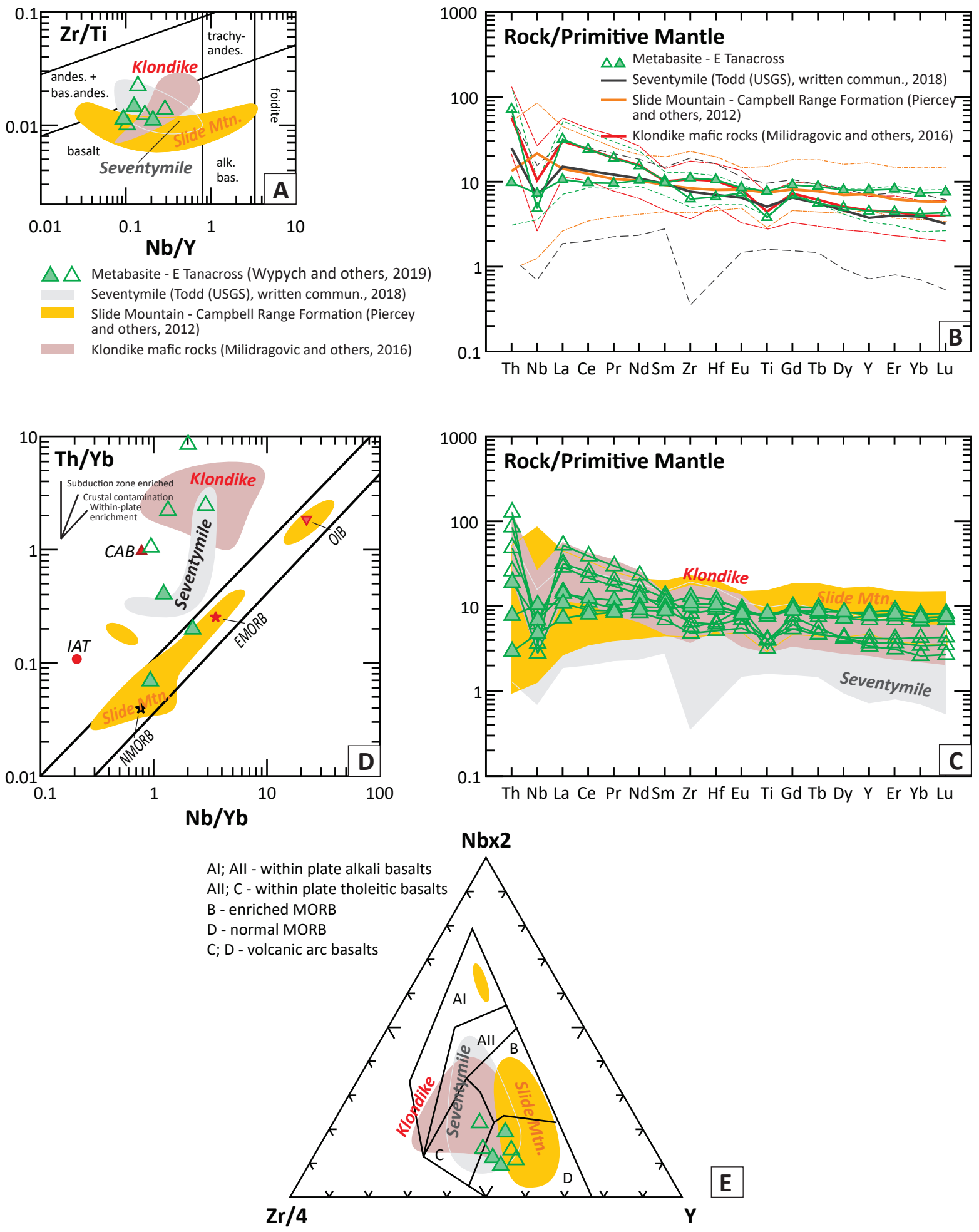

Figure 3. Trace element geochemistry of metamafic units collected in the Klondike assemblage within the Ladue River-Mount Fairplay map area with comparison to metamafic rocks of the Klondike and Slide Mountain assemblages in Yukon (Milidragovic and others, 2016; Piercey and others, 2012) and the Seventymile assemblage of eastern Alaska (Todd [USGS], written commun., 2018). A. Magma series discrimination diagram of Winchester and Floyd (1977). B. Primitive mantle-normalized spider diagram of Sun and McDonough (1989) with average of sample values (symbols) and sample minimums and maximums (dashed lines). C. Primitive mantle-normalized spider diagram of Sun and McDonough (1989) with all sample values (symbols). D. Th/Yb vs. Nb/Yb basalt classification diagram of Pearce (2008). E. Nb-Zr-Y ternary diagram for basalt tectonic discrimination of Meschede (1986). 
istic of the Lake George assemblage and is likely related to continental rifting, based on the trace-element geochemistry. The Jarvis belt in the eastern Alaska Range and in the Ladue River-Mount Fairplay map area likely correlates with the White River assemblage in western Yukon.

\section{ACKNOWLEDGMENTS}

We thank Cynthia Dusel-Bacon and Doug C. Kreiner for helpful reviews of this report. This project was jointly funded by the State of Alaska and the U.S. Geological Survey's Earth Mapping Resources Initiative (Earth MRI) through cooperative agreement G19AC00262. The views and conclusions contained in this document are those of the authors and should not be interpreted as representing the opinions or policies of the U.S. Geological Survey. Mention of trade names or commercial products does not constitute their endorsement by the U.S. Geological Survey.

\section{REFERENCES}

Beranek, L.P., and Mortensen, J.K., 2011, The timing of provenance record of the Late Permian Klondike orogeny in northwestern Canada and arc-continent collision along western North America: Tectonics, v. 30, 23 p. https://doi. org/10.1029/2010TC002849

Cockfield, W.E., 1921, Sixtymile and Ladue Rivers area, Yukon: Canada Geological Survey Memoir 123, no. 105, 60 p.

Colpron, Maurice, Nelson, J.L., and Murphy, D.C., 2006, A tectonostratigraphic framework for the pericratonic terranes of the northern Canadian Cordillera: Paleozoic Evolution and Metallogeny of Pericratonic Terranes at the Ancient Pacific Margin of North America, Canadian and Alaskan Cordillera, in Colpron, Maurice and Nelson, J.L., eds., Geological Association of Canada Special Paper 45, p. 1-23.

Dashevsky, S.S., Schaefer, C.F., and Hunter, E.N., 2003, Bedrock geologic map of the Delta mineral belt, Tok mining district, Alaska: Alaska Division of Geological \& Geophysical Surveys Professional Report 122, 122 p., 2 sheets, scale 1:63,360. https://doi.org/10.14509/2923
Day, W.C., Aleinikoff, J.N., Roberts, Paul, Smith, Moira, Gamble, B.M., Henning, M.W., Gough, L.P., and Morath, L.C., 2003, Geologic map of the Big Delta B-2 Quadrangle, east-central Alaska: U.S. Geological Survey Geologic Investigations Series Map 2788, 1 sheet, scale 1:63,360.

Dusel-Bacon, Cynthia, and Cooper, K.M., 1999, Trace-element geochemistry of metabasaltic rocks from the Yukon-Tanana Upland and implications for the origin of tectonic assemblages in east-central Alaska: Canadian Journal of Earth Sciences, v. 36, no. 10, p. 1,671-1,695.

Dusel-Bacon, Cynthia, Hopkins, M.J., Mortensen, J.K., Dashevsky, S.S., Bressler, J.R., Day, W.C., 2006, Paleozoic tectonic and metallogenic evolution of the pericratonic rocks of east-central Alaska and adjacent Yukon Territory: Paleozoic Evolution and Metallogeny of Pericratonic Terranes at the Ancient Pacific Margin of North America, Canadian and Alaskan Cordillera, Colpron, in Maurice and Nelson, J.L., eds., Geological Association of Canada Special Paper 45, p. 25-74.

Dusel-Bacon, Cynthia, Lanphere, M.A., Sharp, W.D., Layer, P.W., and Hanson, V.L., 2002, Mesozoic thermal history and timing of structural events for the Yukon-Tanana Upland, east-central Alaska - ${ }^{40} \mathrm{Ar} /{ }^{39} \mathrm{Ar}$ data from metamorphic and plutonic rocks: Canadian Journal of Earth Sciences, v. 39, no. 6, p. 1,013-1,051.

Dusel-Bacon, Cynthia, Wooden, J.L., and Hopkins, M.J., 2004, U-Pb zircon and geochemical evidence for bimodal mid-Paleozoic magmatism and syngenetic base-metal mineralization in the Yukon-Tanana terrane, Alaska: Geological Society of America, Bulletin v. 116, no. 7-8, p. 989-1,015.

Foster, H.L., 1970, Reconnaissance Geologic Map of the Tanacross Quadrangle, Alaska: U.S. Geological Survey Miscellaneous Geologic Investigations Map 593, 1 sheet, scale 1:250,000.

Jones III, J.V., and Benowitz, J.A., 2020, ${ }^{40} \mathrm{Ar} /{ }^{39} \mathrm{Ar}$ isotopic data and ages for rocks from the $\mathrm{Yu}$ kon-Tanana upland of eastern Alaska and the northern Aleutian Range of south-central Alaska: U.S. Geological Survey data release. https:// doi.org/10.5066/P96762V3

Jones III, J.V., and O'Sullivan, Paul, 2020, U-Pb isotopic data and ages of zircon, titanite, and 
detrital zircon from rocks from the Yukon-Tanana Upland, Alaska: U.S. Geological Survey data release. https://doi.org/10.5066/P9WWV93S

Jones III, J.V., Todd, Erin, Caine, J.S., Holm-Denoma, C.S., Ryan, J.J., and Benowitz, J.A., 2017, Late Permian (ca. 267-257 Ma) magmatism, deformation, and metamorphism and lithotectonic associations of the Ladue River unit in east-central Alaska: Geological Society of America Abstracts with Programs, v. 49, no. 6. https://doi.org/10.1130/abs/2017AM-304170

Mair, J.L., Hart, C.J.R., Stephens, J.R., 2006, Deformation history of the northwestern Selwyn Basin, Yukon, Canada: Implications for orogen evolution and mid-Cretaceous magmatism: Geological Society of America Bulletin, v. 118, p. 304-323.

Meschede, Martin, 1986, A method of discriminating between different types of midocean ridge basalts and continental tholeiites with the $\mathrm{Nb}-\mathrm{Zr}-\mathrm{Y}$ diagram: Chemical Geology, v. 56, p, 207-218. https://doi.org/10.1016/00092541(86)90004-5

Milidragovic, Dejan, Ryan, J.J., Zagorevski, Alexandre, Piercey, S.J., 2016, Geochemistry of Permian rocks of the Yukon-Tanana terrane, western Yukon: GEMS 2 Cordillera project: Geological Survey of Canada Open File 8170, 21 p.

Naibert, T.J., Benowitz, J.A., Wypych, Alicja, Sicard, K.R., and Twelker, Evan, 2020, ${ }^{40} \mathrm{Ar} /{ }^{39} \mathrm{Ar}$ data from the Tanacross D-1 and parts of the D-2, C-1, and C-2 quadrangles, Alaska: Alaska Division of Geological \& Geophysical Surveys Raw Data File 2020-12, 35 p. https://doi. org/10.14509/30466

Newberry, R.J., and Twelker, Evan, 2021, Metamorphism of the Ladue River-Mount Fairplay area, in Twelker, Evan, ed., Geologic investigation of the Ladue River-Mount Fairplay area, eastern Alaska: Alaska Division of Geological \& Geophysical Surveys Report of Investigation 2021-5B. https://doi.org/10.14509/30736

Pearce, Julian, 2008, Geochemical fingerprinting of oceanic basalts with applications to ophiolite classification and the search for Archean oceanic crust: Lithosphere, v. 100, p. 14-48. https://doi. org/10.1016/j.lithos.2007.06.016

Piercey, S.J., and Colpron, Maurice, 2009, Composition and provenance of the Snowcap assemblage, basement to the Yukon-Tanana terrane, northern Cordillera: Implications for Cordilleran crustal growth: Geosphere, v. 5, p. 439-464. https://doi.org/10.1130/GES00505.1

Piercey, S.J., Mortensen, J.K., Murphy, D.C., Paradis, Suzanne, and Creaser, R.A., 2002, Geochemistry and tectonic significance of alkalic mafic magmatism in the Yukon-Tanana terrane, Finlayson Lake region, Yukon: Canadian Journal of Earth Science, v. 39, p. 1,729-1,744. https:// doi.org/10.1139/e02-090

Piercey, S.J., Murphy, D.C., Creaser, R.A., 2012, Lithosphere-asthenosphere mixing in a transform-dominated late Paleozoic backarc basin: Implications for northern Cordilleran crustal growth and assembly: Geosphere, v. 8, p. 716739. https://doi.org/10.1130/GES00757.1

Ryan, J.J., Zagorevsky, Alexandre, Roots, C.F., and Joyce, N.L., 2014, Paleozoic tectonostratigraphy of the northern Stevenson Ridge area, Yukon: Geological Survey of Canada, Current Research 2014-4, 13 p. https://doi.org/10.4095/293924

Ryan, J.J., Zagorevski, Alexandre, Williams, S.P., Roots, C.F., Ciolkiewicz, Witold, Hayward, Nathan, Chapman, J.B., 2013, Geology, Stevenson Ridge (northwest part), Yukon: Geological Survey of Canada, Canadian Geoscience Map 117, 1 sheet, scale 1:100,000.

Sicard, K.R., Naibert, T.J., Hubbard, T.D., Twelker, Evan, Wypych, Alicja, Werdon, M.B., Willingham, A.L., Gillis, R.J., Lande, L.L., and Newberry, R.J., 2017, Geologic map of the Tok River area, Tanacross A-5 and A-6 quadrangles, eastern Alaska Range, Alaska: Alaska Division of Geological \& Geophysical Surveys Preliminary Interpretive Report 2017-3, 15 p., 1 sheet, scale 1:63,360. https://doi.org/10.14509/29722

Solie, D.N., Werdon, M.B., Freeman, L.K., Newberry, R.J., Szumigala, D.J., Speeter, G.G., and Elliott, B.A., 2019, Bedrock-geologic map, Alaska Highway corridor, Tetlin Junction, Alaska to Canada border: Alaska Division of Geological \& Geophysical Surveys Preliminary In- 
terpretive Report 2019-3, 16 p., 2 sheets, scale 1:63,360. https://doi.org/10.14509/30038

Sun, Weidong, and McDonough, William, 1989, Chemical and isotopic systematics of oceanic basalts: Implications for mantle composition and processes: Geological Society of London, Special Publication 42, p. 313-345. http://dx.doi. org/10.1144/GSL.SP.1989.042.01.19

Szumigala, D.J., Newberry, R.J., Werdon, M.B., Athey, J.E., Flynn, R.L., and Clautice, K.H., 2002, Bedrock geologic map of the Eagle A-1 Quadrangle, Fortymile mining district: Alaska Division of Geological \& Geophysical Surveys Preliminary Interpretive Report 2002-1B, 1 sheet, scale 1:63,360. https://doi. org/10.14509/2864

Todd, Erin, Wypych, Alicja, and Kylander-Clark, Andrew, 2019, U-Pb and Lu-Hf isotope, age, and trace element data from zircon separates from the Tanacross D-1, and parts of D-2, C-1, and C-2 quadrangles: Alaska Division of Geological \& Geophysical Surveys Raw Data File 2019-5, 10 p. https://doi.org/10.14509/30198

Twelker, Evan, Newberry, R.J., Wypych, Alicja, Naibert, T.J., Wildland, A.D., Sicard, K.R., Regan, S.P., Athey, J.E., Wyatt, W.C., and Lopez, J.A., 2021, Bedrock geologic map of the Ladue River-Mount Fairplay area, Tanacross and Nabesna quadrangles, Alaska, in Twelker, Evan, ed., Geologic investigation of the Ladue River-Mount Fairplay area, eastern Alaska: Alaska Division of Geological \& Geophysical Surveys Report of Investigation 2021-5A. https://doi. org/10.14509/30735

Wildland, A.D., Wypych, Alicja, Regan, S.P., and Holland, Mark, 2021, U-Pb zircon ages from bedrock samples collected in the Tanacross and Nabesna quadrangles, eastern Alaska: Alaska Division of Geological \& Geophysical Surveys Preliminary Interpretive Report 2021-4, 47 p. https://doi.org/10.14509/30732

Winchester, J.A., and Floyd, P.A., 1977, Geochemical discrimination of different magma series and their differentiation products using immobile elements: Chemical Geology, v. 20, p. 325-343.

Werdon, M.B., Newberry, R.J., and Szumigala, D.J., 2001, Bedrock geologic map of the Ea- gle A-2 Quadrangle, Fortymile mining district, Alaska: Alaska Division of Geological \& Geophysical Surveys Preliminary Interpretive Report 2001-3B, 1 sheet, scale 1:63,360. https://doi. org/10.14509/2670

Wypych, Alicja, Hubbard, T.D., Naibert, T.J., Athey, J.E., Newberry, R.J., Sicard, K.R., Twelker, Evan, Werdon, M.B., Willingham, A.L., Wyatt, W.C., and Lockett, A.C., 2021, Northeast Tanacross geologic map and map units and descriptions, in Wypych, Alicja, ed., Northeast Tanacross geologic mapping project, Alaska: Alaska Division of Geological \& Geophysical Surveys Report of Investigation 2020-9B. https://doi.org/10.14509/30539

Wypych, Alicja, Naibert, T.J., Athey, J.E., Newberry, R.J., Sicard, K.R., Twelker, Evan, Werdon, M.B., Willingham, A.L., and Wyatt, W.C., 2018, Major-oxide and trace-element geochemical data from rocks collected in 2018 for the Northeast Tanacross project, Tanacross C-1, C-2, D-1, and D-2 quadrangles, Alaska: Alaska Division of Geological \& Geophysical Surveys Raw Data File 2018-4, 4 p. https://doi. org/10.14509/30113

Wypych, Alicja, Twelker, Evan, Athey, J.E., Lockett, A.C., Naibert, T.J., Sicard, K.R., Werdon, M.B., and Willingham, A.L., 2017, Major-oxide and trace-element geochemical data from rocks collected in the Tanacross C-1, D-1, and D-2 quadrangles, Alaska in 2017: Alaska Division of Geological \& Geophysical Surveys Raw Data File 2017-10, 4 p. https://doi.org/10.14509/29778

Wypych, Alicja, Twelker, Evan, Naibert, T.J., Athey, J.E., Newberry, R.J., Lopez, J.A., Regan, S.P., Sicard, K.R., Wildland, A.D., and Wyatt, W.C., 2019, Major-oxide and trace-element geochemical data from rocks collected in 2019 for the Eastern Tanacross project, Tanacross and part of Nabesna quadrangles, Alaska: Alaska Division of Geological \& Geophysical Surveys Raw Data File 2019-8, 3 p. https://doi.org/10.14509/30267

Yukon Geological Survey, 2020. Yukon Geochronology - A database of Yukon isotopic age determinations: Yukon Geological Survey. https:// data.geology.gov.yk.ca/Compilation/22 [accessed January, 1, 2021] 


\section{CHAPTER D: STRUCTURAL GEOLOGY OF THE MOUNT FAIRPLAY-LADUE RIVER AREA}

Alec D. Wildland ${ }^{1}$ and Travis J. Naibert ${ }^{1}$

\section{INTRODUCTION}

During the 2019 field season, the Mineral Resources section of the Alaska Division of Geological \& Geophysical Surveys (DGGS) conducted helicopter-supported bedrock geologic mapping of the Mount Fairplay-Ladue River region, a 4,800 $\mathrm{km}^{2}$ area of the Yukon-Tanana Upland of eastern Alaska. DGGS geologists collected 549 structure measurements, discussed by section below based on the planar feature type, and where appropriate, subdivided by host units. The majority are metamorphic foliations and fold-axial planes. Limited measurements of linear features, such as fold axes, stretched minerals, and intersections lineations, are recorded where observed. Measurements of bedding, fault surfaces, joint surfaces, and vein walls are also limited. Complete field descriptions and locations for station numbers cited can be found in Naibert and others (2020b). Our new geologic mapping (Twelker and others, 2021) extensively revises the known extent of metamorphic terrane boundaries, igneous rocks, and faults. Analysis of the new structural data was undertaken to test prior workers' metamorphic history and tectonic interpretations for the region, and it provides insights into local structural features within the context of their host unit.

Field observations of metamorphic assemblages in our map area suggest a regional stacking order, from bottom to top, including Paleozoic amphibolite-facies gneiss and amphibolite of the parautochthonous Lake George assemblage, Proterozoic to Mississippian partially retrograded amphibolite-facies allochthonous Yukon-Tanana Terrane (YTT) rocks of the Ladue River unit, and Permian greenschist-facies metavolcanic Yukon-Tanana Terrane rocks of the Klondike assemblage (Twelker and others, 2021). The Yukon-Tanana Upland is an area of generally poor exposure, however, previous workers have interpreted a complex polydeformational history throughout eastern Alaska and Yukon, Canada. There are currently three recognized deformational events prior to and since the Permian (Beranek and others, 2011; Dusel-Bacon and others, 1995; Hansen and Dusel-Bacon, 1998). The oldest deformation occurred during west-dipping Late Permian to Triassic subduction beneath the YTT when it was still distal to North America. Permian $\mathrm{U}-\mathrm{Pb}$ crystallization ages of intrusive rocks support this event known as the Klondike orogeny and it is responsible for the formation, deformation, and metamorphism of the Klondike assemblage, along with the magmatism observed in Yukon and locally in eastern Alaska (Beranek and others, 2011). Subsequent Jurassic margin-parallel contraction thrust the allochthonous terranes northwest and structurally over the parautochthonous Lake George assemblage. Top-to-the-northwest shear is variably recorded in both the lower and upper-plate assemblages from this period of thrusting (Hansen and Dusel-Bacon, 1998). Finally, mid-Cretaceous extension juxtaposed the structurally lower parautochthonous assemblages and the allochthonous units. Top-to-the-southeast shear is dominantly recorded in the Lake George assemblage and is locally observed in the allochthon (Fortymile River assemblage and Ladue River unit) near the boundary with Lake George (Berman and others, 2007; Hansen and Dusel-Bacon, 1998; Staples and others, 2016).

The cooling history of the metamorphic assemblages in and around the map area has been constrained by ${ }^{40} \mathrm{Ar} /{ }^{39} \mathrm{Ar}$ thermochronology, which often represents a mappable discontinuity in eastern Alaska (Dusel-Bacon and others, 2002). These cooling ages are likely a signature of metamor-

${ }^{1}$ Alaska Division of Geological \& Geophysical Surveys, 3354 College Rd., Fairbanks, Alaska 99709-3707 
phism which accompanied the deformational events as discussed above. The parautochthonous Lake George assemblage yields Cretaceous cooling ages (ca. 100-120 Ma) (Pavlis and others, 1993; Naibert and others, 2020a). This age range coincides with exhumation and juxtaposition of the Lake George assemblage with assemblages of the YTT (Pavlis, 1989; Hansen, 1990; Hansen and Dusel-Bacon, 1998). The allochthonous assemblages of the YTT near the Ladue River generally yield Triassic to Jurassic ${ }^{40} \mathrm{Ar} /{ }^{39} \mathrm{Ar}$ cooling ages (Jones and Benowitz, 2020) interpreted to record cooling during thrusting of allochthonous rocks structurally over pericratonic North America (Dusel-Bacon and others, 2002; Jones and others, 2017; Naibert and others, 2020a; Pavlis and others, 1993; Solie and others, 2019). The ${ }^{40} \mathrm{Ar} /{ }^{39} \mathrm{Ar}$ thermochronology ages are consistently found within these assemblages and have become defining features.

\section{DISCUSSION OF STRUCTURAL MEASUREMENTS}

The majority of structure measurements in the field area are metamorphic-tectonic foliations and to a lesser extent axial plane, fold axis, and mineral lineations. This report will discuss these data in the context of their respective assemblages as mapped in the field area.

\section{Metamorphic and Tectonic Foliation}

The Lake George assemblage represents the parautochthonous North American craton in the field area. The poles to foliation vary substantially in trend with consistent average moderate to steep plunges. These data do not show obvious signs of folding; such as girdle patterns or multiple clusters (fig. 1A). These folding patterns may have been disrupted by locally observed crenulation cleavage. The allochthonous rocks of the Ladue River unit cover a substantial portion of the map area. Foliation measurements are similar to foliations in the Lake George assemblage with moderately to steeply plunging poles to foliation (fig. 1B). There are also no discernible patterns or clusters. The Permian Klondike assemblage is ubiquitously greenschist-facies and is variably described as chloritic schist, greenstone, and lesser quartz-muscovite schist. The spatial extent of Klondike assemblage in eastern Alaska is under investigation, but in our field area it is the structurally highest portion of the allochthonous Yukon Tanana terrane, overlying the Ladue River unit. The mean vector of foliation poles plots slightly to the southwest compared to the Lake George assemblage and Ladue River unit mean vectors (fig. 1C). Some dispersion of foliation orientations may be due to tilting associated with post-metamorphic high-angle faults.
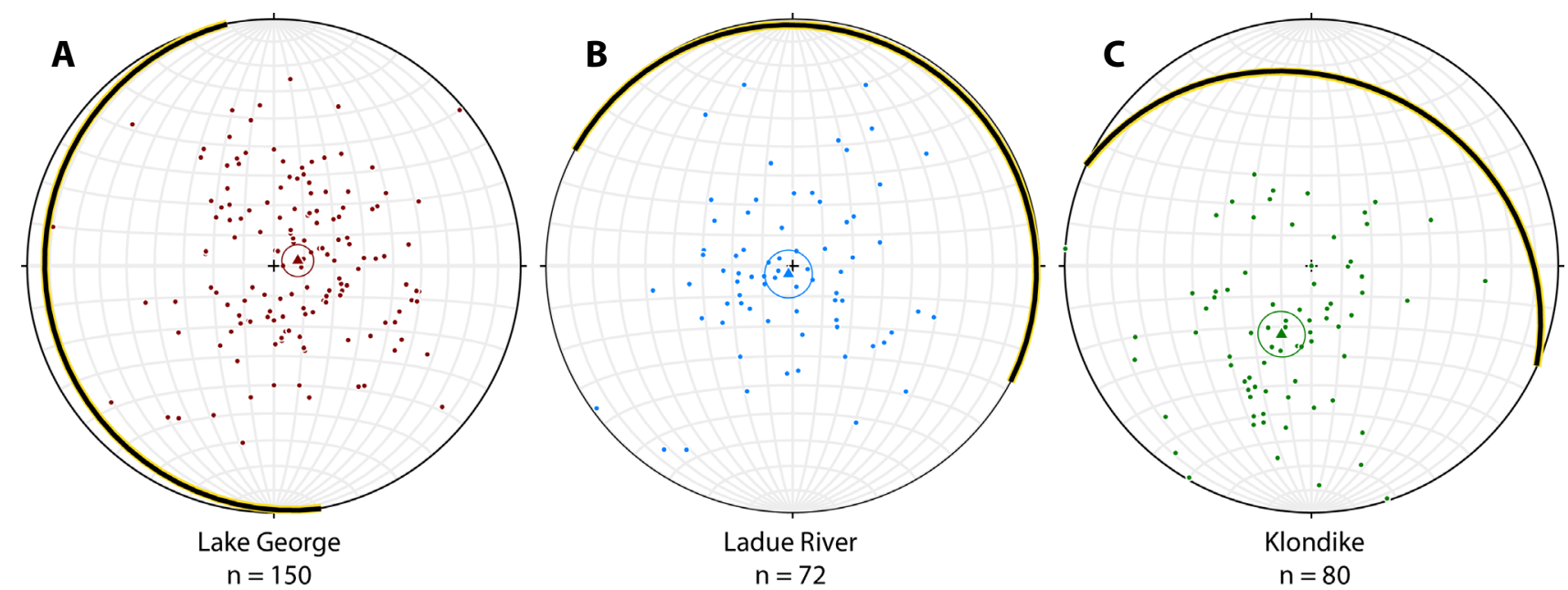

Figure 1. Equal-area stereonet plots of poles to foliation and average foliation planes (black lines highlighted in yellow) for: (A) Lake George assemblage (brown): average plane strikes 169 and dips 8; (B) Ladue River unit (blue): average plane strikes 298 and dips 3; and, (C) Klondike assemblage (green): average plane strikes 294 and dips 25. 


\section{Folding}

The scattered foliation data of the Lake George assemblage may indicate that there are not enough measurements to resolve folding at the map scale, or that the scale of folding differs substantially from the map scale. This is at odds with field observations of folding within outcrops. Both meterscale open (60-120 degree) folds and centimeterto meter-scale recumbent isoclinal folds were observed in the main metamorphic foliation of the Lake George assemblage (fig. 2A). Even though these folds are dominantly asymmetric, a consistent fold vergence was not noted in the field. However, the axial planes strike from northeast to southeast and on average dip moderately to shallowly to the south, which implies northward vergence (fig. 3A). Eighty percent of fold axis measurements have an average trend northeast-southwest. Mineral and stretching lineations, primarily from K-feldspar porphyroclasts, are typically northwest-southeast, locally northeast-southwest, and are moderately to shallowly plunging (fig. 4A). The northeast-southwest-trending fold axes mentioned above appear to correspond to northwest-southeast mineral lineations commonly found within the Lake George assemblage. The distribution of foliations, axial planes, and linear features is difficult to relate to

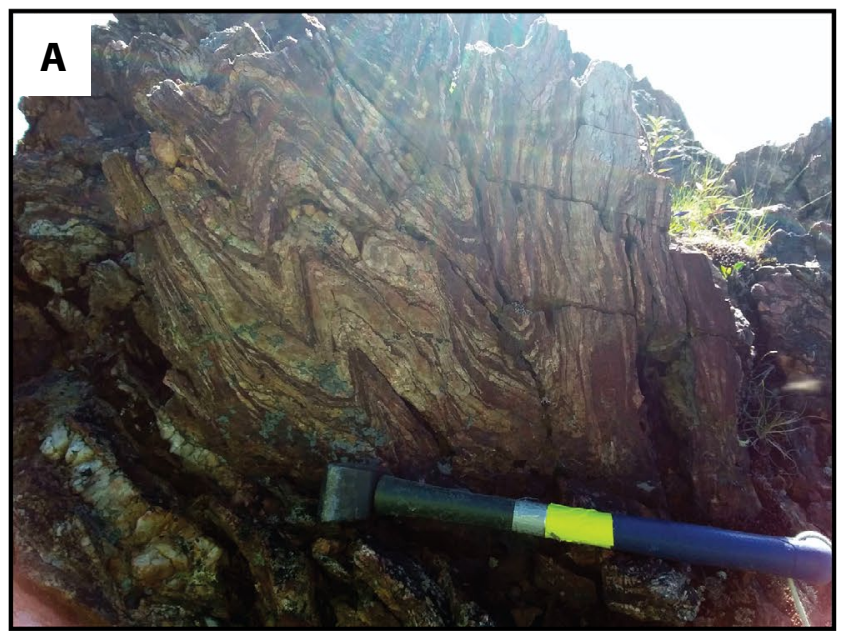

deformational events owing to poor exposure throughout the field area.

Map-scale folding is not clearly recorded in the generally scattered foliation data collected in the allochthonous rocks of the Ladue River unit. Observed folds in the field are dominated by outcrop-scale open folds (fig. 2B). Isoclinal and slightly asymmetric folding of the dominant foliation was also observed locally. Folds within this unit often have northwest vergence. Half of the axial planes strike east-west and dip shallowly to the south similar to stations within the Lake George assemblage (fig. 3B). A notable difference is that the Ladue River unit stations have southeast-trending fold axes compared to southwest-trending fold axes in the Lake George assemblage. Several unique axial plane measurements with north-northwest strikes and steep dips were collected at one location in the northwest area of the map (19KS334). Associated fold axes trend to the northwest with shallow plunges. Stretching lineations within the Ladue River unit are all shallowly plunging with two possible sub populations which trend north-northeast and east-west, respectively (fig. 4B).

Axial plane strikes measured within the Klondike assemblage vary from northwest to southwest and are steeply to moderately dipping to the north as opposed

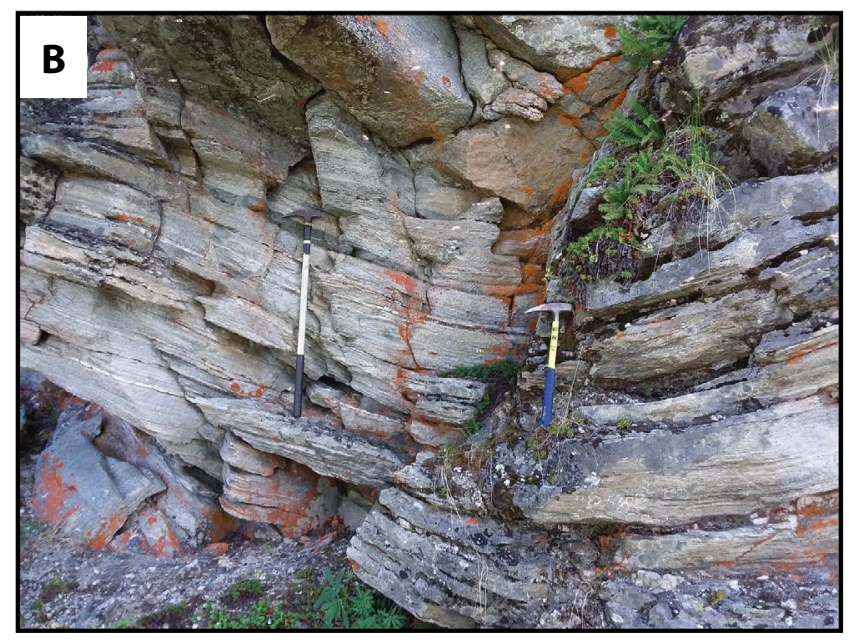

Figure 2. Observed folding: (A) station 19ADW201; Lake George assemblage metasedimentary rocks (MDlgs) highlights an early foliation that is isoclinally folded within the dominant later foliation of the Lake George assemblage; (B) station 19JAL082; metamorphic rocks of the Ladue River unit (MDpo) displaying large-scale open folds. 

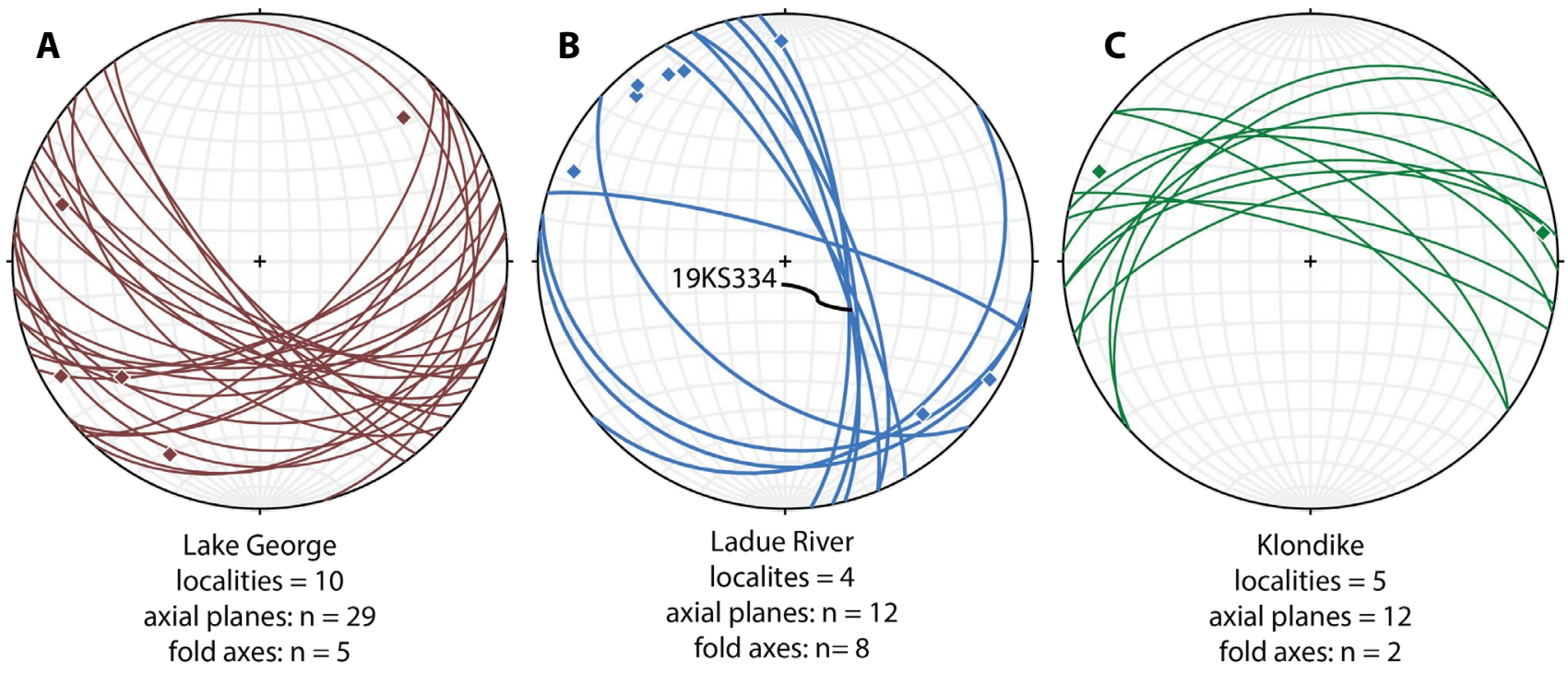

Figure 3. Equal-area stereonet plots of axial planes and fold axes: (A) Lake George assemblage (brown); (B) Ladue River units (blue); and, (C) Klondike assemblage (green).
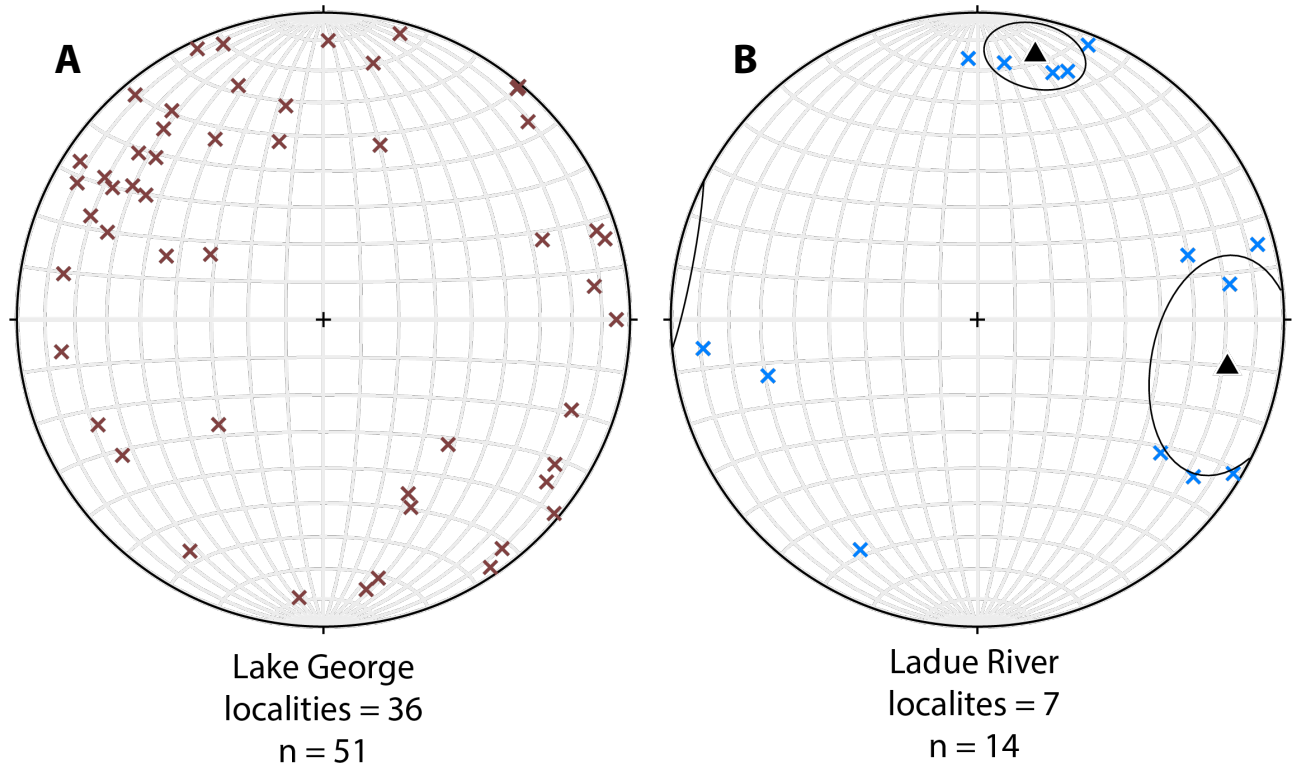

Figure 4. Equal-area stereonet plots of mineral and stretching lineations: (A) Lake George; and, (B) Ladue River. Mean vector of two sub-populations indicated by black triangles.

to the southward dipping axial planes observed in the other units. The two recorded fold axis measurements within the Klondike trend east-west (fig. 3C). Folding is asymmetric with possible vergence to the south.

\section{Shear Zone and Ductile Kinematics}

The geology of the map area is divided into the allochthonous Yukon-Tanana Terrane (Ladue River unit and Klondike assemblage) and parau- tochthonous North America (Lake George assemblage), each having separate Mesozoic structural histories suggested by geochronology, differences in ages of magmatism, and metamorphic P-T histories (Beranek and Mortenson, 2011; Dusel-Bacon and others, 1995, 2002, Hansen and Dusel-Bacon, 1998; Pavlis and others, 1993; Staples and others, 2016). The Klondike assemblage is distinguished 


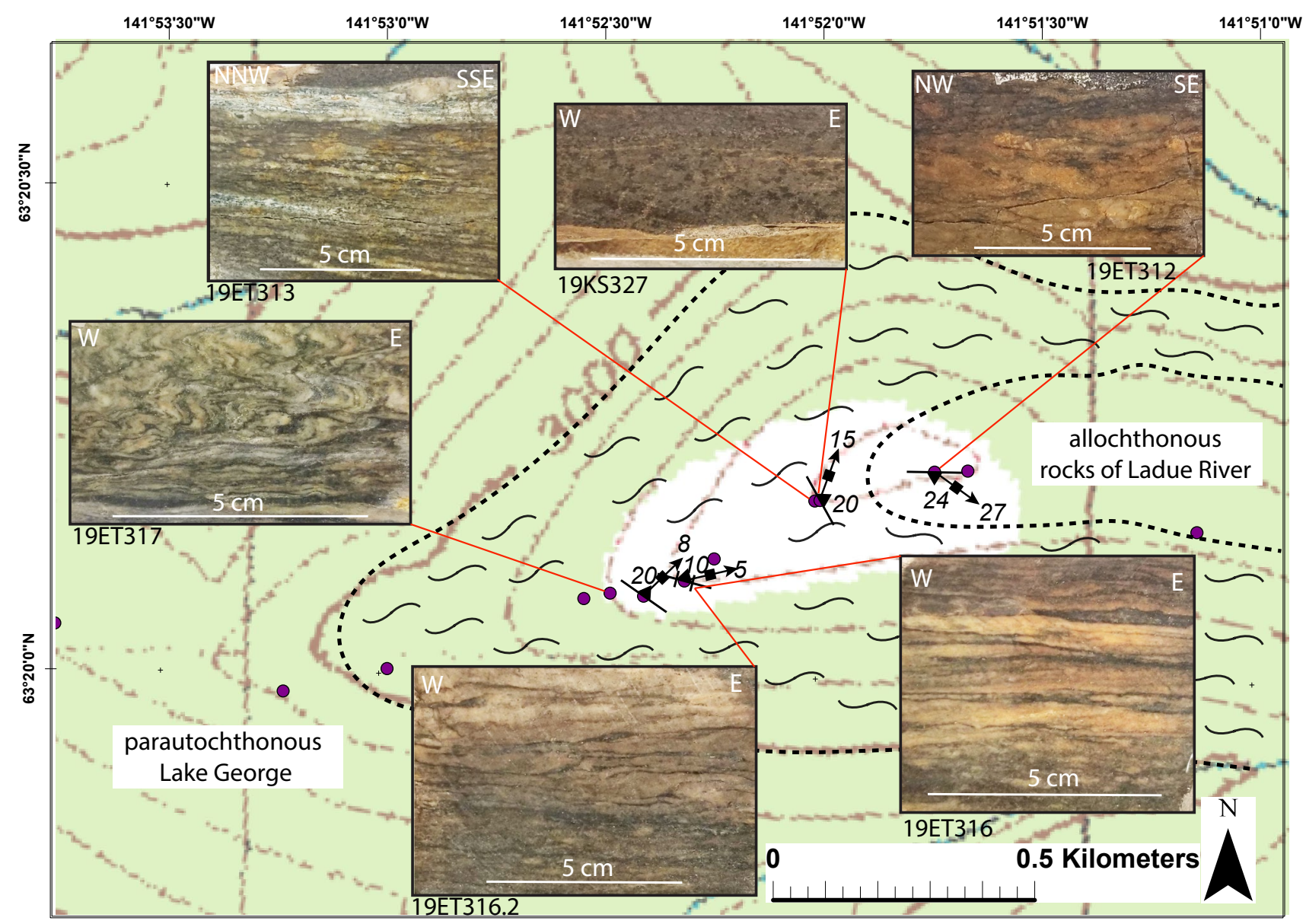

Figure 5. Mylonitic shear zone separating dominantly greenschist-facies allochthonous rocks of the Ladue River unit from the underlying amphibolite-facies (partially retrograded) Lake George assemblage. Field observations (sigma clasts, fold vergences) indicate top-to-the northeast shear sense.

from the allochthonous rocks of the Ladue River unit in that it never experienced metamorphic conditions above greenschist facies. Previous and current work suggest that the terranes are bound by low-angle ductile shear zones (Dusel-Bacon and others, 1995, 2002; Pavlis and others, 1993; Wypych and others, 2019). These shear zones may have accommodated both northwest-directed Jurassic thrusting, which placed the YTT structurally above parautochthonous North America, and southeast-directed mid-Cretaceous extension bringing the terranes to their present-day configuration (Hansen and Dusel-Bacon, 1998; DuselBacon and others, 2002; O'Neill and others, 2010).

Shear sense indicators are difficult to find in the map area due to poor exposure, and observed outcrops often have ambiguous or symmetrical kinematics. DGGS geologists located an outcropping shear zone separating the allochthonous rocks of the Ladue River unit from the underlying Lake George assemblage (fig. 5). Samples collected across this boundary have experienced varying degrees of grain-size reduction and range from protomylonitic to mylonitic in texture. Most kinematic indicators (mineral lineations, sigma clasts) suggest top-to-thenortheast shear sense. However, fold vergence observations and stretched mineral lineations suggest local top-to-the-northwest shear sense. There is evidence of within-assemblage shearing and mylonitization that is not associated with terrane or lithology unit boundaries, as illustrated in figure 6 . Within the Lake George assemblage, our mapping documents broadly distributed shear zone localities, typically 


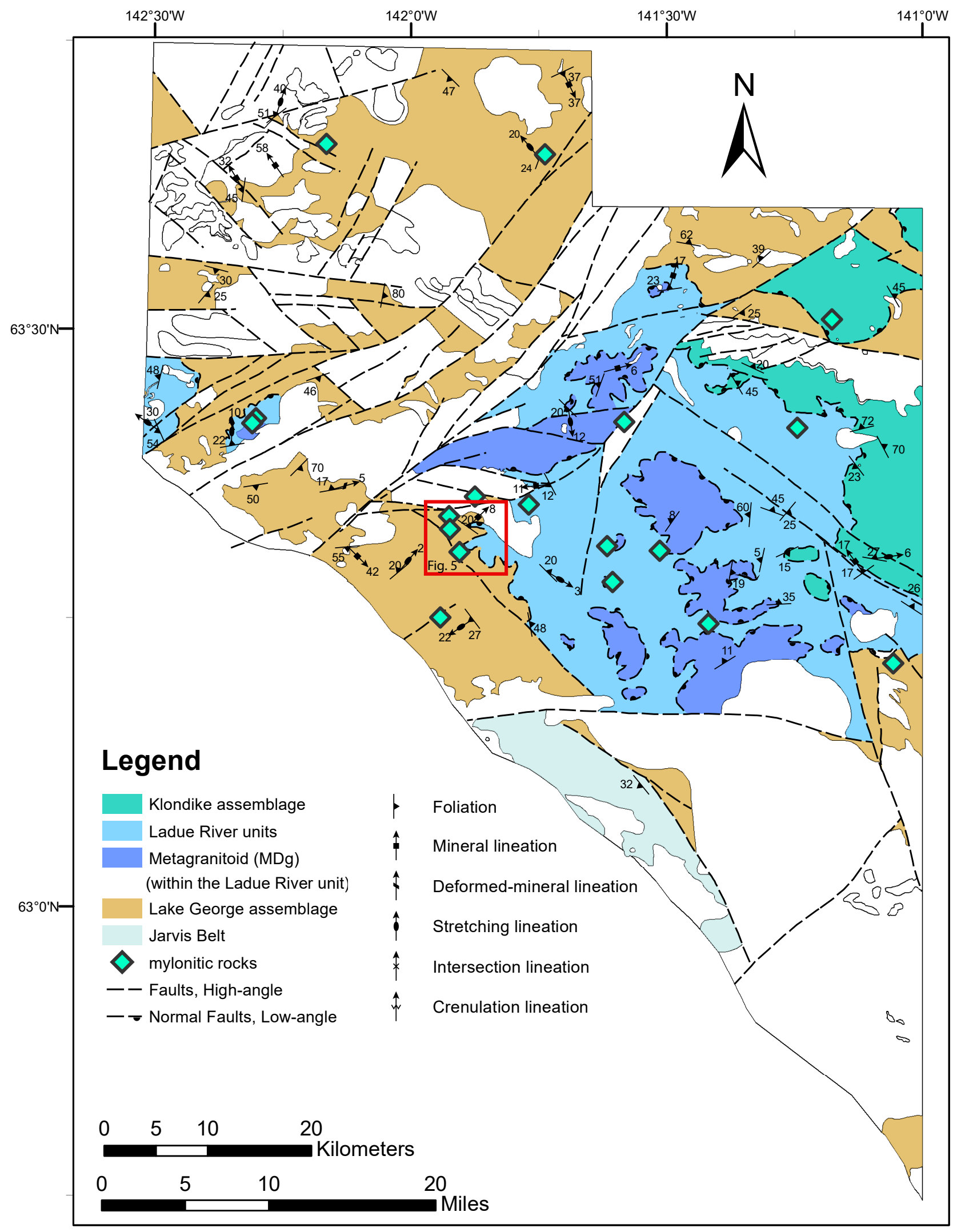

Figure 6. Map highlighting selected foliation and lineation measurements. Green diamonds are locations where shearing or mylonitization is recorded in field notes or observed in thin section. Red box shows location of shear zone illustrated in figure 5. 
with top-to-the-southeast motion based on kinematic indicators including sigma and delta clasts, shear bands, and stretching lineations of K-feldspar porphyroclasts (fig. 7A, B). This within-assemblage shearing may suggest a more complicated anastomosing behavior common within large-scale shear zones (Fossen and Cavalcante, 2017). The degree of connectivity between potential strands of a larger anastomosing shear zone is not well constrained given the lack of exposure.

Mylonitic foliations are generally oriented parallel to the main shallowly dipping folia- tions observed in the whole field area. However, one location east of Mount Fairplay recorded an anomalous steeply dipping mylonitic foliation with greenschist-facies mineralogy (station 19SPR196), which bisects the more dominant sub-horizontal foliation of a Lake George amphibolite-facies orthogneiss. This younger, lowergrade fabric has top-to-the-southeast kinematics consistent with the vergence of shallower tectonic components, but it has a much steeper down-dip stretching lineation which trends to the southeast (fig. 8).

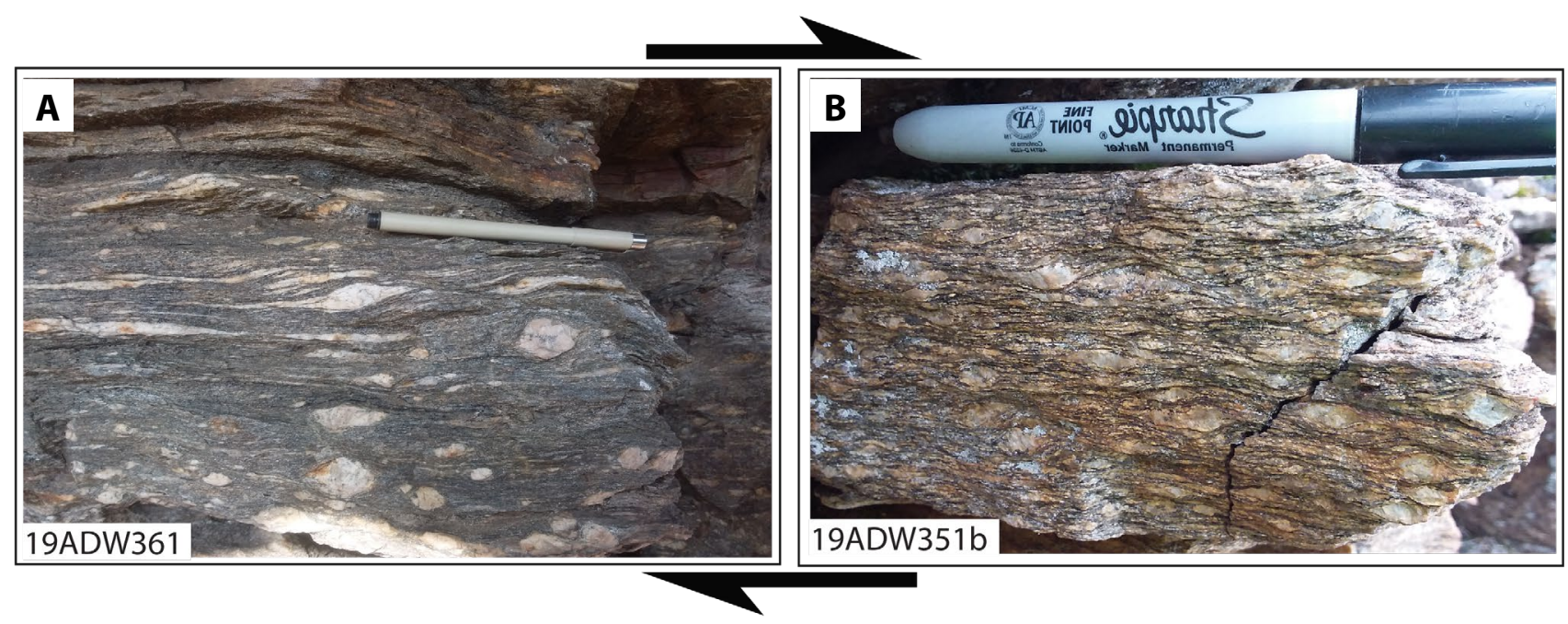

Figure 7. Examples of shear sense indicators and mylonitization from augen orthogneiss in the Lake George assemblage displaying top-to-the-southeast shear sense: (A) shear band; and, (B) sigma and delta clasts.

\section{Bedding}

Bedding measurements were collected in mid- to Late Cretaceous and Paleogene volcanic-volcaniclastic rocks with well-defined laminations or compaction layering. Bedding measurements within volcanic units are assumed to be indicators of paleohorizontal and our interpretations of post-eruption tilting of the volcanic units is built on the assumption that the volcanic beds were deposited horizontally. However, the volcanic air fall units could have bedding that more closely reflects paleotopography, especially if the units are relatively thin. Further observations of volcanic unit thickness and Cretaceous to Eocene paleoto- pography could validate these preliminary results. The volcanic units include the mid-Cretaceous West Fork felsic tuff (Kwff), Late Cretaceous felsic volcanic rocks (IKfv), Late Cretaceous alkaline volcanic rocks (IKav), and Paleogene rhyolite (Prr). Bedding observations within the West Fork felsic tuff (Kwff) and the felsic volcanic rocks (IKfv) on the west side of the map area near Mount Fairplay strikes between 160 and 260 degrees and dips shallowly to moderately to the northwest. At one locality, bedding within the felsic volcanic rocks (IKfv) dips slightly steeper with a similar strike (fig. 9A). This may indicate that little to no significant tilting occurred between the deposition of the West 

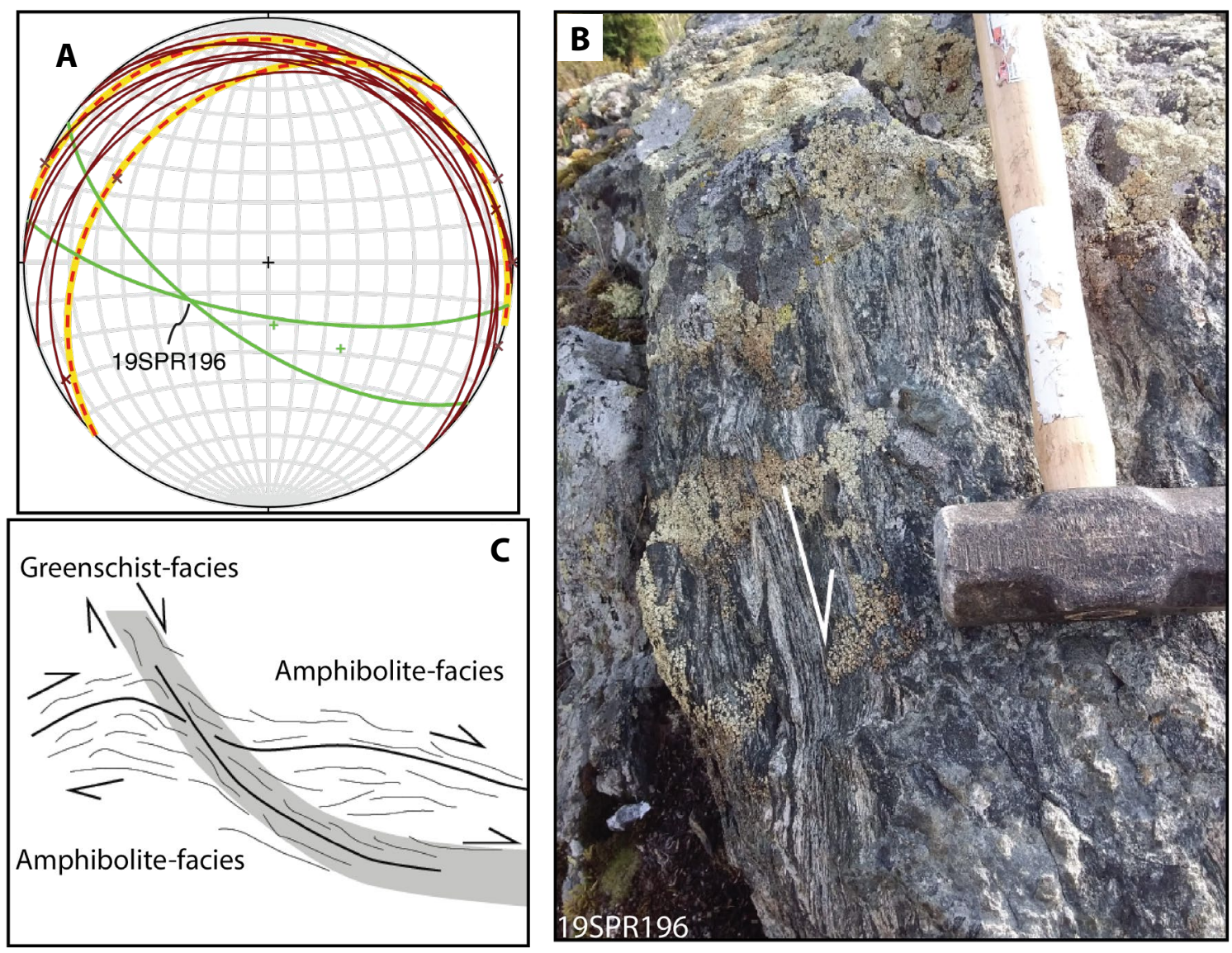

Figure 8. A closer look at samples $5 \mathrm{~km}$ east of Mount Fairplay displaying top-to-the-southeast kinematics of sample 19SPR196 and nearby dominant subhorizontal foliation found within the Lake George assemblage: (A) Equal-area stereonet plots of mylonitic greenschist-facies foliation of 19SPR196 (green) cutting dominant foliation (brown). Other Lake George mylonitic foliations from 40-50 km further southeast (shown by dashed red lines highlighted in yellow). "X's" and "plus signs" are corresponding mineral lineations; (B) 19SPR196 outcrop with shear sense; and, (C) Schematic of dominant Lake George foliation and kinematics with mylonitic greenschist-facies rock bisecting.

Fork felsic tuff Kwff (ca. 107.9 $\pm 0.3 \mathrm{Ma}$; sample 19TJN299; Wildland and others [2021]) and the felsic volcanic rocks IKfv $(-70-75 \mathrm{Ma}$ based on geochemical similarity to Late Cretaceous intrusions (IKfd; sample 19RN359; $70.5 \pm 0.8 \mathrm{Ma}$; Wildland and others, 2021). In the eastern map area near Yukon border, bedding orientations within the alkaline volcanic rocks (IKav) strike between 230 and 295 degrees and dip shallowly to moderately to the north-northwest, similar to nearby foliations of the Klondike assemblage (fig. 9b). One locality within the Paleogene rhyolite unit ( $\mathrm{REr}$ ) has a bedding measurement that plots within the dominant alkaline volcanic rocks (IKav) population. Another location strikes 330 degrees and dips more to the northeast. A third location has two bedding measurements that strike between 60 and 70 degrees and dip steeply to the southeast. These data may indicate that tilting of the alkaline volcanic rocks (IKav) occurred both before and after the Paleogene rhyolites were erupted and deposited at $58.7 \pm 0.2 \mathrm{Ma}$ (sample 19AW256; Wildland and others, 2021). Nearby high-angle east-westand northeast-southwest-striking faults are a likely explanation for the observed tilting in the eastern map area volcanic rocks.

\section{Dike and Vein Walls}

Andesitic to felsic dikes are common throughout the field area and typically have aphanitic to porphyritic textures. Dikes are often found 


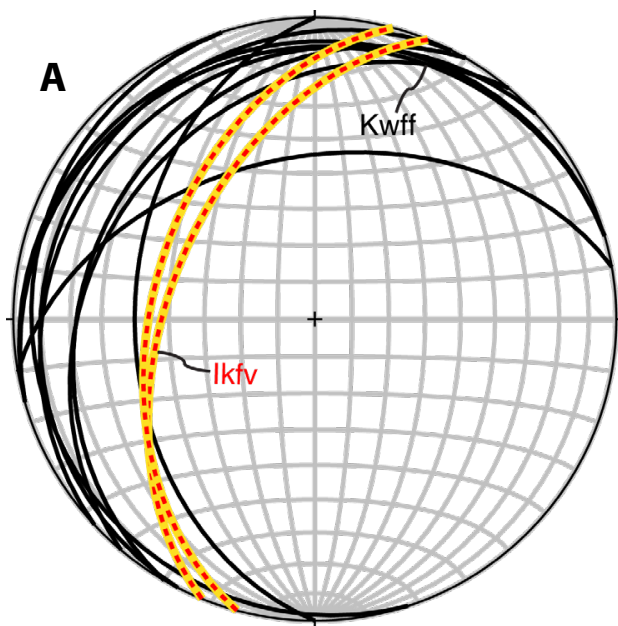

bedding (west area) Kwff: localities $=8 ; n=12$ lkfv: localities $=1 ; n=2$

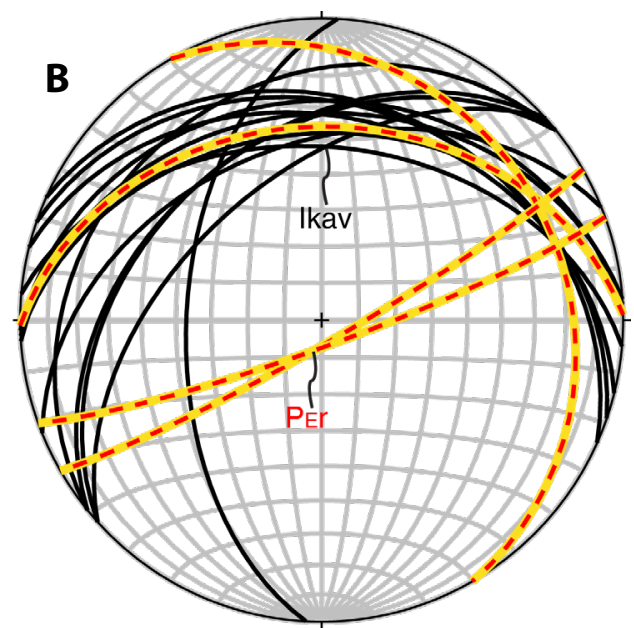

bedding (east area) Ikav: localities $=7 ; n=13$ Per: localities $=3 ; n=4$

Figure 9. Equal-area stereonet plot of bedding and compaction layering: (A) Bedding measurements in units Kwff (solid black lines) and IKfv (red and yellow dashed lines); and, (B) Bedding measurements in units IKav (solid black lines) and PEr (red and yellow dashed lines).

within, or neighboring, mid-Cretaceous plutons, similar to dike observations in the adjacent northeastern Tanacross map area (Wypych and others, 2019). Structurally, there appears to be no spatial or lithological pattern regarding dike orientations in this map area. Five dikes strike northeast-southwest and four strike northwest-southeast; all are moderately to steeply dipping (fig. 10A).

Vein walls are often parallel or subparallel to foliation and their measurements cluster in two populations (fig. 10B): (1) a cluster of northeast-trending high-angle planes (shown in red); and, (2) a group of shallowly dipping, northwest-striking measurements taken from a small area in the southeast corner of the map from a few different localities (shown in black) (stations: 19AW014; 19KS033; 19KS036). The northeast-trending veins have similar orientation to that of fractures and joints (discussed below) and the nearby Sixtymile-Pika fault zone.

\section{Faults and Fractures}

Due to limited exposure and recessive weathering of fault zones, only ten fault measurements were collected. A dominant northeast-south- west-striking set of faults were mapped in the area based on topography, geophysical surveys (Burns and others, 2020a,b), and observed lithology changes. Most measured fault orientations are high angle and strike north-south, an orientation that is not dominant on the map scale. Northeast-striking faults were recorded at stations $19 \mathrm{KS} 076$ and 19KS414 (fig. 11A). Where slickenlines were noted on a fault surface (19SPR081; quartz-rich felsic hypabyssal intrusion), they were described as a shear fracture surface with crescentic gouges indicating a steeply plunging down-dip lineation.

Orientation data of fracture and joint surfaces are summarized in figure 11 . The majority of poles to fracture and joint surface measurements trend northwest-southeast with moderate to shallow plunge (fig. 11B), but the diffuse preferred orientations are difficult to interpret. However, parsing by igneous rock units provides insight into preferred orientations within mid-Cretaceous plutons, Paleogene volcanic rocks, and the Mount Fairplay intrusive complex (fig. 11C). Joints and fracture surfaces within mid-Cretaceous plutons (pink diamonds) display two populations of mean vectors: 1) west-trending poles with steep plunge, and 

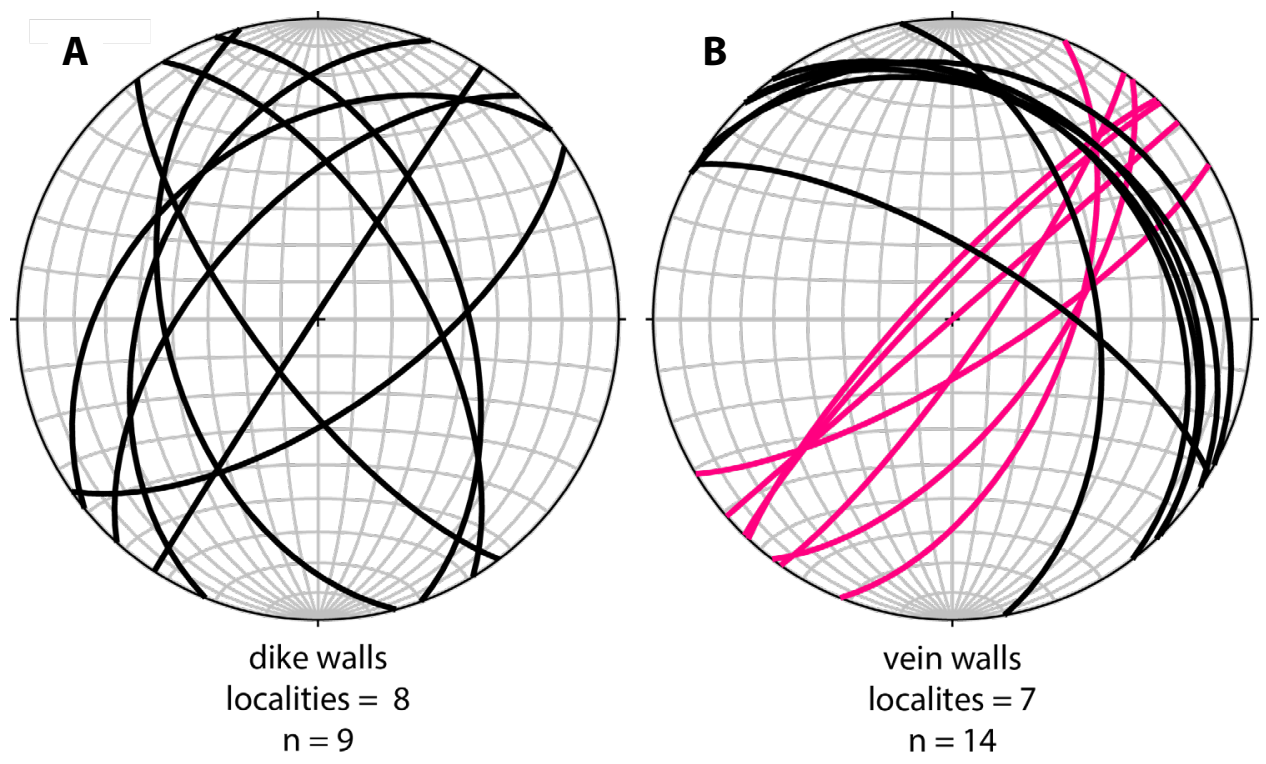

Figure 10. Equal-area stereonet plots: (A) dike walls; and, (B) vein walls. Northeast-striking measurements similar to joints observed near high-angle Sixtymile-Pika fault zone shown in pink.

2) northeast-trending poles with moderate plunge. The Paleogene volcanic rocks in the east side of the field area display a mean vector with northwest-trending poles with shallow-moderate plunge. Finally, joint-fracture data within the Mount Fairplay intrusions display southeast-trending poles with shallow plunge. Igneous rocks of other ages (Paleogene and Cretaceous), and remaining metamorphic assemblages (Ladue River unit and Klondike assemblage), either have insufficient data or no preferred orientation (fig. 11D).

\section{CONCLUSIONS}

Our foliation and folding observations are generally consistent with previous worker's interpretations (Hansen and Dusel-Bacon, 1998; Wypych and others, 2019). Metamorphic units record moderate to strong foliations that are subhorizontal to moderately dipping. This main foliation formed subsequent to an earlier generation of isoclinally folded foliations, suggesting at least two generations of foliation development. Mylonitic foliations are typically oriented parallel to the main shallowly dipping foliation. Ductile kinematic indicators within the Lake George assemblage dominantly record top-to-the-southeast shear, locally top-tothe-northwest (Hansen and Dusel-Bacon, 1998), and the structurally higher units of the YTT variably record both top-to-the-northwest and top-tothe-southeast shear, as previously noted by Hansen and Dusel-Bacon (1998). We also provide evidence of within-assemblage shearing and mylonitization that is not associated with terrane or lithology unit boundaries. Within the Lake George assemblage, our mapping documents broadly distributed shear zone localities, which suggest more complicated, possibly anastomosing, shear occurred below the YTT-Lake George boundary.

Additionally, we highlight that high-angle east-west and northeast-southwest striking faults are a likely explanation for the observed northward tilting of volcanic unit IKav and southward tilting of unit PEr, which occurred both before and after the Paleogene volcanics were erupted at $58.7 \pm 0.2$ Ma. Tilting does not seem to have occurred on all high-angle faults in the area, as volcanic units near the Taylor Highway experienced little apparent tilting between the deposition of Kwff (ca. 107.9 \pm $0.3 \mathrm{Ma})$ and IKfv $(-70-75 \mathrm{Ma})$. 


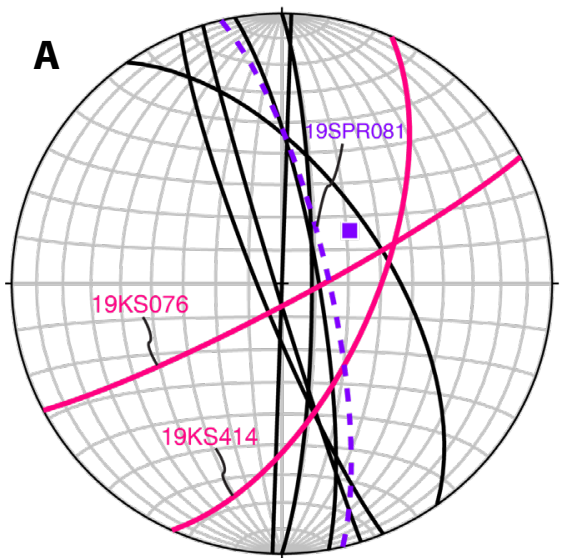

faults

localities $=4$

$\mathrm{n}=10$

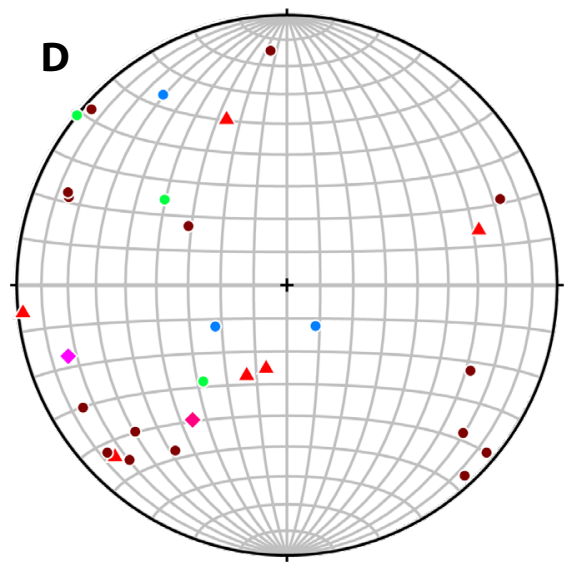

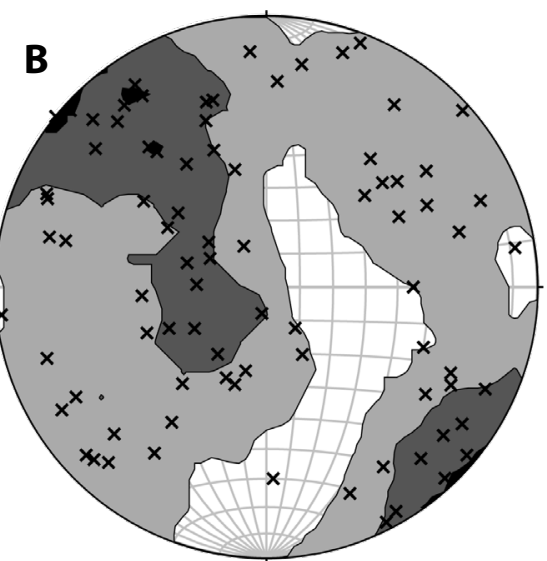

fractures and joints

localities $=28$

$\mathrm{n}=83$

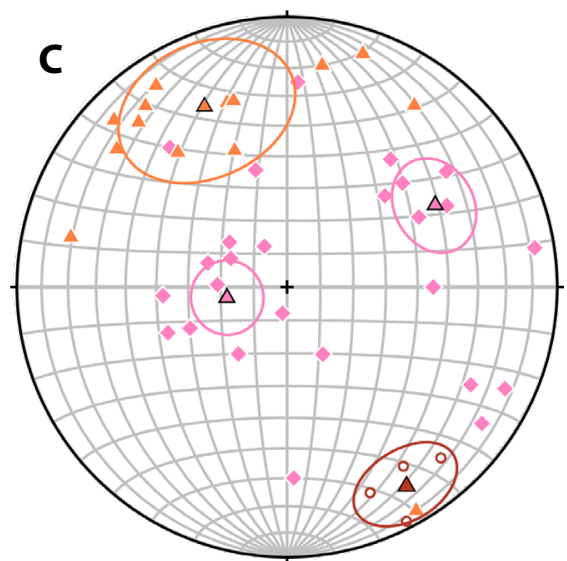

fractures and joints

mid-K plutons: localities $=5 ; \mathrm{n}=26$

Mt. Fairplay complex: localities $=1 ; n=4$

Paleogene volcanic: localities $=2 ; n=14$

Figure 11. Equal-area stereonet plots: (A) faults planes; purple dashed line and square represent fault plane with accompanying slickenline: trend $=52$, plunge $=64 ;(B)$ poles to fracture and joint surfaces. Kamb contour interval $=2 \sigma$; significance level = $3 \sigma$; and $(\mathbf{C})$ poles to fracture and joint surface orientations separated by rock unit. Mid-Cretaceous plutons (pink diamonds) mean vectors: 1) trend/plunge= 260.0; 71.6; and, 2) trend/plunge=61.0; 37.4. Paleogene volcanics mean vector with trend/plunge $=335.4 ; 27.4$. Mount Fairplay intrusion mean vector trend/plunge= 149; 15.1. (D) Map units with insufficient data or measurements with no preferred orientation.

\section{ACKNOWLEDGMENTS}

The authors would like to thank the DGGS Mineral Resources geologists and other DGGS staff who contributed data collection, scientific discussions, and other support. This project was jointly funded by the State of Alaska and the U.S. Geological Survey's Earth Mapping Resources Initiative (Earth MRI) through cooperative agreement G19AC00262. The views and conclusions contained in this document are those of the authors and should not be interpreted as representing the opinions or policies of the U.S. Geological Survey. Mention of trade names or commercial products does not constitute their endorsement by the U.S. Geological Survey.

Stereonet plots made with the Stereonet program by Cardozo and Allmendinger (2013). 


\section{REFERENCES}

Beranek, L.P. and Mortensen, J.K., 2011, The timing and provenance record of the Late Permian Klondike orogeny in northwestern Canada and arc-continent collision along western North America: Tectonics, v. 30, TC5017. https://doi. org/10.1029/2010TC002849

Berman, R.G., Ryan, J.J., Gordey, S.P. and Villeneuve, M., 2007, Permian to Cretaceous polymetamorphic evolution of the Stewart River region, Yukon-Tanana terrane, Yukon, Canada: P-T evolution linked with in situ SHRIMP monazite geochronology: Journal of Metamorphic Geology, v. 25, p. 803-827. https://doi-org.uaf.idm.oclc.org/10.1111/j.1525 -1314.2007.00729.x

Burns, L.E., Graham, G.R.C., Barefoot, J.D., Naibert, T.J., Fugro Airborne Surveys Corp., and Fugro GeoServices, Inc., 2020a, Ladue electromagnetic and magnetic airborne geophysical survey data compilation: Alaska Division of Geological \& Geophysical Surveys Geophysical Report 2019-20, 15 p. https://doi.org/10.14509/30261

Burns, L.E., Graham, G.E., Emond, A.M., Stevens Exploration Management Corp., and Fugro Airborne Surveys, 2020b, Alaska Highway corridor electromagnetic and magnetic airborne geophysical survey data compilation: Alaska Division of Geological \& Geophysical Surveys Geophysical Report 2020-15, 17 p. https://doi. org/10.14509/30462

Cardozo, Nestor, and Allmendinger, R.W., 2013, Spherical projections with OSXStereonet: Computers \& Geosciences, v. 51, p. 193-205. https://doi.org/10.1016/j.cageo.2012.07.021

Dusel-Bacon, Cynthia, Hansen, V.L., and Scala, J.A., 1995, High-pressure amphibolite facies dynamic metamorphism and the Mesozoic tectonic evolution of an ancient continental margin, east-central Alaska: Journal of Metamorphic Geology, v. 15, p. 9-24. https://doi.org/10.1111/j.1525-1314.1995. tb00202.x

Dusel-Bacon, Cynthia, Lanphere, M.A., Sharp, W.D., Layer, P.W., and Hanson, V.L., 2002, Mesozoic thermal history and timing of structural events for the Yukon-Tanana Upland, east-cen- tral Alaska- ${ }^{40} \mathrm{Ar} /{ }^{39} \mathrm{Ar}$ data from metamorphic and plutonic rocks: Canadian Journal of Earth Sciences, v. 39, n. 6, p. 1,013-1,051. https:// doi.org/10.1139/e02-018

Fossen, Haakon, and Cavalcante, G.C.G., 2017, Shear zones - A review; Earth-Science Reviews, v. 171, p. 434-455. https://doi.org/10.1016/j. earscirev.2017.05.002

Hansen, V.L., 1990, Yukon-Tanana terrane; a partial acquittal: Geology, v. 18, p. 365-369. https://dggs.alaska.gov/pubs/id/17433

Hansen, V.L., and Dusel-Bacon, Cynthia, 1998, Structural and kinematic evolution of the Yukon-Tanana Upland tectonites, east-central Alaska-A record of late Paleozoic to Mesozoic crustal assembly: Geological Society of America Bulletin, v. 110 , n. 2, p. 211-230. https:// doi.org/10.1130/0016-7606(1998)110<0211: SAKEOT > 2.3.CO;2

Jones, J.V., III and Benowitz, J.A., 2020, ${ }^{40} \mathrm{Ar} /{ }^{39} \mathrm{Ar}$ isotopic data and ages for rocks from the $\mathrm{Yu}$ kon-Tanana upland of eastern Alaska and the northern Aleutian Range of south-central Alaska: U.S. Geological Survey data release. https:// doi.org/10.5066/P96762V3

Jones, J.V., Todd, E., Caine, J.S., Holm-Denoma, C.S., Ryan, J.J. and Benowitz, J.A., 2017, October. Late Permian (CA. 267-257 MA) magmatism, deformation, and metamorphism and lithotectonic associations of the Ladue River Unit in east-central Alaska. In Geological Society of America Annual Meeting in Seattle, Washington, USA-2017. Geological Society of America.

Naibert, T.J., Benowitz, J.A., Wypych, Alicja, Sicard, K.R., and Twelker, Evan, 2020a, ${ }^{40} \mathrm{Ar} /{ }^{39} \mathrm{Ar}$ data from the Tanacross D-1 and parts of the D-2, C-1, and C-2 quadrangles, Alaska: Alaska Division of Geological \& Geophysical Surveys Raw Data File 2020-12, 35 p. https://doi. org/10.14509/30466

Naibert, T.J., Twelker, Evan, Wypych, Alicja, Athey, J.E., Newberry, R.J., Lopez, J.A., Regan, S.P., Sicard, K.R., Wildland, A.D., and Wyatt, W.C., 2020b, Field station locations and magnetic susceptibility data collected in 2019 for the Eastern Tanacross Project, Tanacross and Nabesna quad- 
rangles, Alaska: Alaska Division of Geological \& Geophysical Surveys Raw Data File 2019-9, 2 p. https://doi.org/10.14509/30268

O'Neill, J.M., Day, W.C., Aleinikoff, J.N., and Saltus, R.W., 2010, The Black Mountain tectonic zone-a reactivated northeast trending crustal shear zone in the Yukon-Tanana Upland of east-central Alaska, in Gough, L.P., and Day, W.C., eds., Recent U.S. Geological Survey studies in the Tintina Gold Province, Alaska, United States, and Yukon, Canada-results of a 5 year project: U.S. Geological Survey Scientific Investigations Report 2007-5289-D, p. D1-D8.

Pavlis, T.L., 1989, Middle Cretaceous orogenesis in the northern Cordillera: A Mediterranean analog of collision-related extensional tectonics: Geology, v. 17, p. 947-950.

Pavlis, T.L., Sisson, V.B., Foster, H.L., Nokleberg, W.J., and Plafker, George, 1993, Mid-Cretaceous extensional tectonics of the Yukon-Tanana Terrane, Trans-Alaska Crustal Transect (TACT), east-central Alaska: Tectonics, v. 12, p. 103-122. https://doi.org/10.1029/92TC00860

Solie, D.N., Werdon, M.B., Freeman, L.K., Newberry, R.J., Szumigala, D.J., Speeter, G.G., and Elliott, B.A., 2019, Bedrock-geologic map, Alaska Highway corridor, Tetlin Junction, Alaska to Canada border: Alaska Division of Geological \& Geophysical Surveys Preliminary Interpretive Report 2019-3, 16 p., 2 sheets, scale 1:63,360. http://doi.org/10.14509/30038

Staples, R.D., H.D. Gibson, Colpron, Maurice, and Ryan, J.J., 2016, An orogenic wedge model for diachronous deformation, metamorphism, and exhumation in the hinterland of the northern Canadian Cordillera: Lithosphere; v. 8, n. 2, p. 165-184. https://doi.org/10.1130/L472.1

Twelker, Evan, Newberry, R.J., Wypych, Alicja, Naibert, T.J., Wildland, A.D., Sicard, K.R., Regan, S.P., Athey, J.E., Wyatt, W.C., and Lopez, J.A., 2021, Bedrock geologic map of the Ladue River-Mount Fairplay area, Tanacross and Nabesna quadrangles, Alaska, in Twelker, Evan, ed., Geologic investigation of the Ladue River-Mount Fairplay area, eastern Alaska: Alaska Division of Geological \& Geophysical Surveys Report of Investigation 2021-5A. https://doi. org/10.14509/30735

Wildland, A.D., Wypych, Alicja, Regan, S.P., and Holland, Mark, 2021, U-Pb zircon ages from bedrock samples collected in the Tanacross and Nabesna quadrangles, eastern Alaska: Alaska Division of Geological \& Geophysical Surveys Preliminary Interpretive Report 2021-4, 47 p. https://doi.org/10.14509/30732

Wypych, Alicja, Hubbard, T.D., Naibert, T.J., Athey, J.E., Newberry, R.J., Sicard, K.R., Twelker, Evan, Werdon, M.B., Willingham, A.L., Wyatt, W.C., and Lockett, A.C., 2019, Northeastern Tanacross geologic map, Tanacross D-1, D-2, C-1, and C-2 quadrangles, Alaska: Alaska Division of Geological \& Geophysical Surveys Preliminary Interpretive Report 2019-6, 20 p., 1 sheet, scale 1:63,360. https://doi.org/10.14509/30197 


\title{
CHAPTER E: GEOCHEMISTRY OF THE IGNEOUS ROCKS IN THE LADUE RIVER-MOUNT FAIRPLAY AREA
}

\author{
Alicja Wypych ${ }^{1}$
}

\section{INTRODUCTION}

During the 2019 summer field season, geologists from the Alaska Division of Geological \& Geophysical Surveys (DGGS) carried out a geologic mapping and geochemical sampling project in the Ladue River-Mount Fairplay map area. We generated modern geochemical data for 408 samples (Wypych and others, 2019), and to support map interpretations, we analyzed 1,685 cut surfaces of hand samples using a handheld X-ray fluorescence (XRF) analyzer calibrated to mafic-to-silicious rock standards. We split igneous rocks into six major groups based on crystallization age, geochemical composition, and textural characteristics: 1) Paleocene to Eocene rhyolite and felsic porphyry; 2) Late Cretaceous volcanic rocks; 3) Late Cretaceous intrusive rocks; 4) Late Cretaceous units of the Mount Fairplay intrusive complex in the northwestern part of the area; 5) mid-Cretaceous volcanic rocks and dikes of McArthur Creek area in the southern tip of the area; and, 6) mid-Cretaceous intrusive and extrusive rocks (fig. 1). The Mount Fairplay complex has been studied in greater detail by Newberry (2020). All units are shown on the total alkali $\left(\mathrm{Na}_{2} \mathrm{O}+\mathrm{K}_{2} \mathrm{O}\right)$ versus silica $\left(\mathrm{SiO}_{2}\right)$ diagram (TAS) for intrusive and volcanic rocks (figs. $2 \mathrm{~A}$ and $\mathrm{B}$ ). The plutonic rocks exhibit a range of mafic to felsic compositions. Similarly, the volcanic rocks have a broad compositional range from mafic to silicic ( $\mathrm{SiO}_{2}$ from 53 to 79 weight percent). A supplemental spreadsheet that relates map units to samples from the geochemical report used for this interpretation can be downloaded from https:// doi.org/10.14509/30739. See Wypych and others (2019; https://dggs.alaska.gov/pubs/id/30267) for full documentation of the sample collection, preparation, and analytical methods.

\section{GEOLOGIC BACKGROUND}

Previous geologic investigations in the eastern Yukon-Tanana Upland region document periods of Triassic to Paleocene igneous activity (Foster, 1970, 1967; Werdon and others, 2001; Szumigala and others, 2002; Dusel-Bacon and others, 2015). Foster (1970) describes felsic lavas, tuffs, tuff breccias, pumice-breccias, volcanic conglomerates, and tuffaceous sediments, as well as mafic lavas, breccias, and tuffs in the region, and assigned them a probable Tertiary age based on pollen fossils found in interbedded sedimentary units, later revised to Cretaceous (Foster and others, 1994). Along with the Tertiary volcanic rocks, Foster (1970) describes equigranular to porphyritic diorite to granite intrusions of Mesozoic age. Due to its associated mineral potential, Mesozoic to Paleogene igneous activity has been further explored. Joyce (2002) investigated the mid-Cretaceous intrusions of the Moosehorn Range, Yukon, immediately adjacent to our map area, where she differentiated granodiorite, felsic and mafic porphyritic dikes, and granites, aplites, and pegmatites using multiple dating systems, geochemical composition, and detailed fieldwork. Extensive and voluminous mid-Cretaceous felsic volcanic rocks in the map area prompted Bacon and others (1990) to interpret these rocks as intra-caldera and near-caldera deposits and propose possible caldera locations. Late Cretaceous igneous activity immediately north of the map area at the Taurus porphyry prospect has been investigated in detail by Lerich (1995), Harrington (2010), Kreiner and others (2019), and the DGGS Mineral Resources section (Wypych and others, 2021; Twelker and Newberry, 2021). DGGS investigations include geochemical and age characterization of the Taurus granodiorite and quartz-feldspar porphyry, the Pika

${ }^{1}$ Alaska Division of Geological \& Geophysical Surveys, 3354 College Rd., Fairbanks, Alaska 99709-3707 


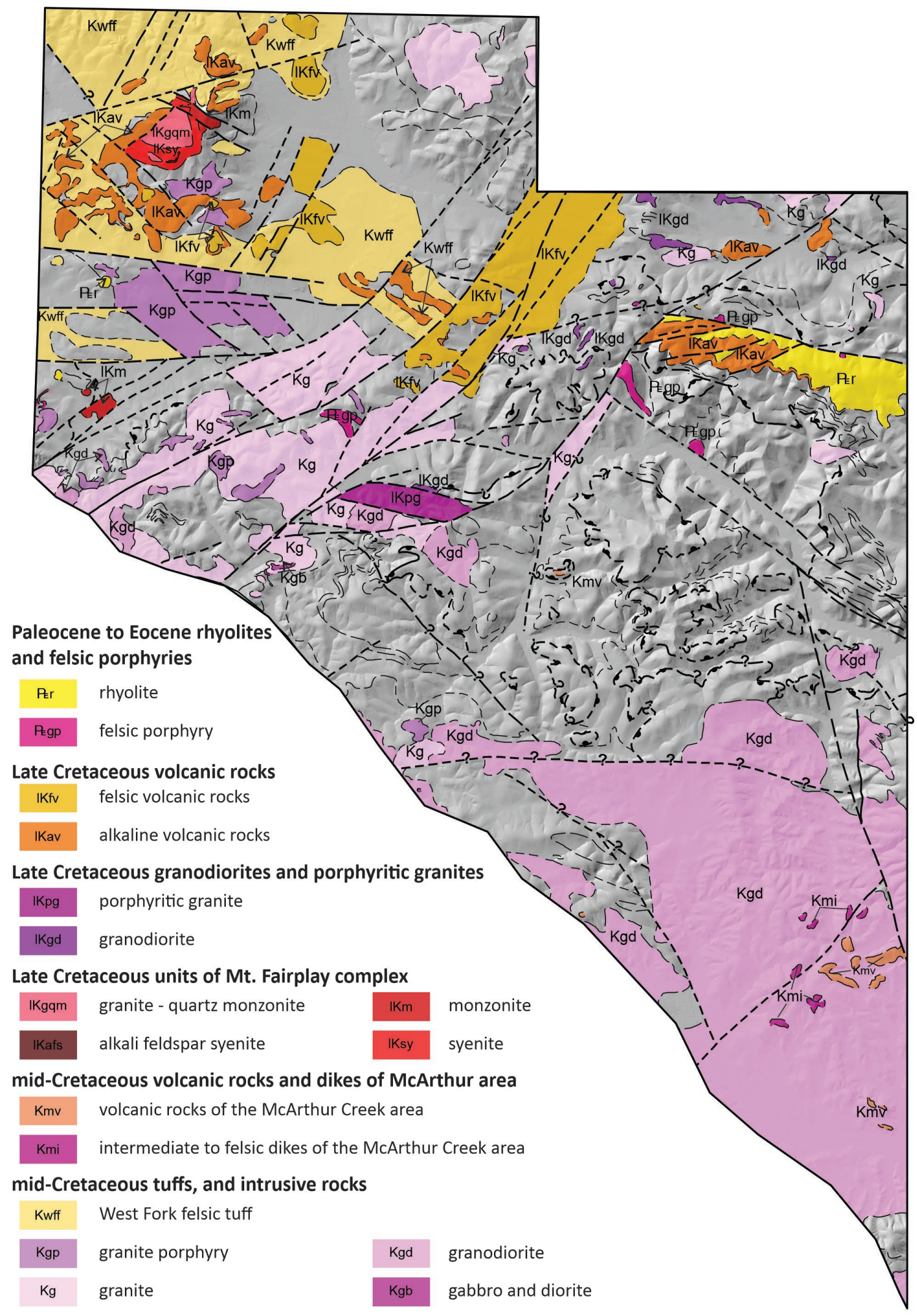

Figure 1. Geographic distribution of igneous units in the Ladue River-Mount Fairplay area (Twelker and others, 2021, sheet 1). Thin dotted, dashed, and continuous fine lines signify unit contacts; thicker dotted, dashed, and continuous lines represent faults. 

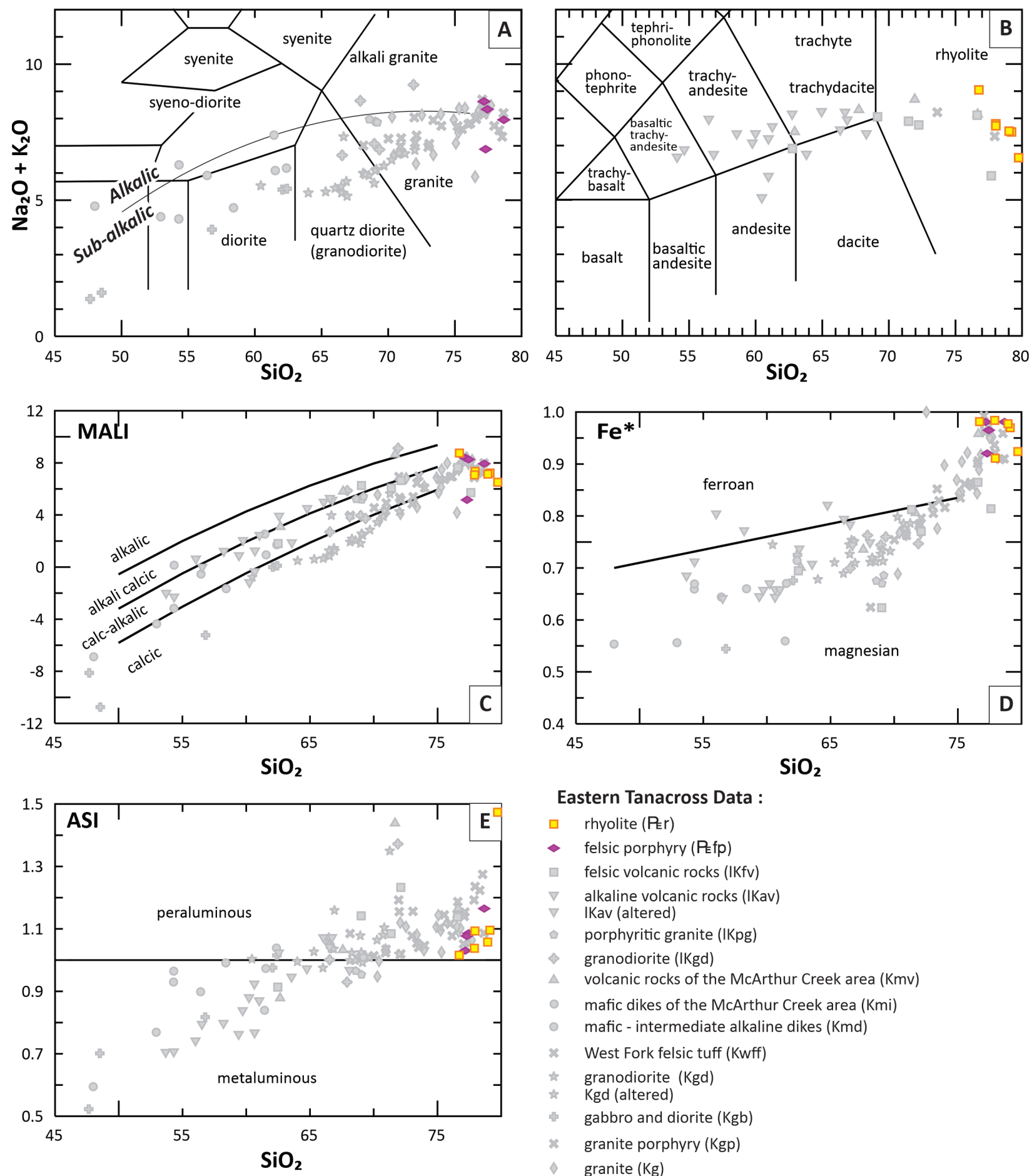

\section{Eastern Tanacross Data :}

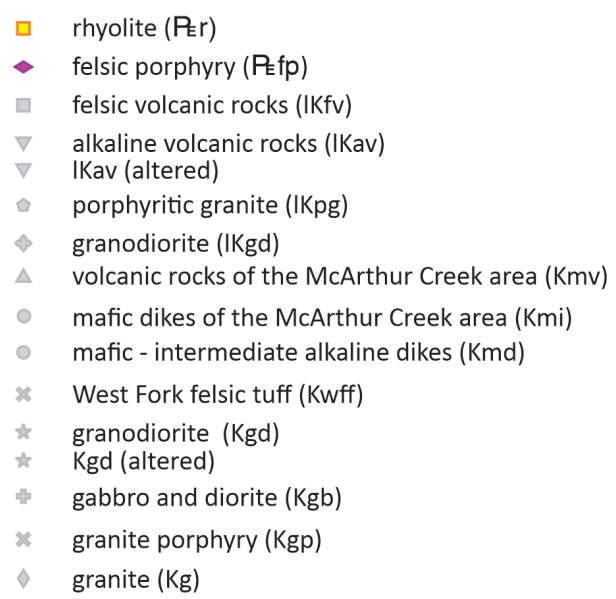

Figure 2. Classification diagrams for Paleogene igneous rocks from the Ladue River-Mount Fairplay area. A. Total alkali versus silica diagram with fields (TAS, labeled after Wilson, 1989) showing the compositional range of the plutonic rocks. B. TAS with fields (after LeBas and others, 1986) showing the compositional range of the volcanic rocks and dikes. C. Modified alkali-lime index (MALI $=\mathrm{Na}_{2} \mathrm{O}+\mathrm{K}_{2} \mathrm{O}-\mathrm{CaO}$; Frost and others, 2001). D. $\mathrm{Fe}^{*}=\left(\mathrm{FeO}_{\mathrm{tot}}\right) /\left(\mathrm{FeO}_{\mathrm{tot}}+\mathrm{MgO}\right) ;$ Frost and others, 2001). E. Aluminum saturation index diagram (ASI = Al / (Ca-1.67P+Na+K); Frost and others, 2001). Oxide data have been normalized to 100-percent anhydrous. 
diorite, and other volcanic rocks (Wypych and others, 2021). The Paleogene felsic igneous rocks are part of a bimodal, extension-related igneous province mapped in the region (for example, Newberry and others, 1996; Werdon and others, 2001). Here, we build on the findings of previous researchers and provide modern, whole-rock geochemical data for the samples in the map area, as well as regional comparisons and tectonic interpretations.

\section{PALEOGENE RHYOLITE AND FELSIC PORPHYRY}

The youngest igneous rocks in the map area are felsic porphyries ( $\mathrm{P} f \mathrm{fp}$ ) and related rhyolites (PEr). The porphyries are mainly present as small plugs and dikes concentrated in the central map area (Twelker and others, 2021), whereas the rhyolite unit consists of rhyolite and felsic tuffs outcropping in a single volcanic field north of Ladue River. The Paleogene units are highly siliceous, with $\mathrm{SiO}_{2}$ greater than 76 weight percent (fig. 2B), and are calc-alkalic to calcic, ferroan, and peraluminous (figs. 2C-E). The trace-element composition of the Paleogene units is distinctive and easily differentiated from older igneous rocks in the region (figs. $3 \mathrm{~A}-\mathrm{F}$ ). With the exception of one outlier with over 600 parts per million (ppm) strontium (Sr) and $300 \mathrm{ppm}$ barium (Ba), the units have low $\mathrm{Sr}$ concentrations (averaging $20 \mathrm{ppm}$, fig. 3A), low europium (Eu, 0.04 to 0.25 ppm, fig. 3D), and low $\mathrm{Ba}$ (15 to $85 \mathrm{ppm}$ ); all of these indicate fractionation of plagioclase and are characteristic of highly evolved magmas. The high field-strength elements (HFSE) are elevated, with thorium (Th) up to 40.7 ppm, yttrium (Y) averaging around $40 \mathrm{ppm}$ and up to $103 \mathrm{ppm}$, and zirconium $(\mathrm{Zr})$ averaging around 200 ppm (figs. 3C, E, and F). Likewise, heavy rare earth elements (REE) are elevated: ytterbium $(\mathrm{Yb})$ reaches near $10 \mathrm{ppm}$, lutetium $(\mathrm{Lu})$ over 1.3 ppm, and hafnium (Hf) nearing 10 ppm, whereas light REE are comparable to other units in the region (fig. 3B). All these trace-element characteristics indicate an extension-related magma source, which is further highlighted by niobium $(\mathrm{Nb})$ plus $\mathrm{Y}$ versus rubidium $(\mathrm{Rb})$ concentrations plotting in the within-plate granitoids field of Pearce and others (1984; fig. 4A). The high Y concentration was easily detectible using a handheld XRF analyzer in the field office, thus allowing immediate recognition of the unit. Figures 3A, 3C, 3E, and 3F illustrate the handheld XRF data in comparison to the ICP-MS-derived trace-element geochemical data.

\section{LATE CRETACEOUS IGNEOUS ROCKS}

Late Cretaceous igneous rocks in the map area are grouped into: volcanic rocks (felsic [IKfv] and alkaline [IKav]); granodiorite to granite (IKgd) and porphyritic granite (IKpg); and, intrusive rocks of Mount Fairplay complex (granite-quartz monzonite [IKgqm]; alkali-feldspar syenite [IKafs]; monzonite $[\mathrm{IKm}]$; and, syenite [IKsy]).

Felsic volcanic rocks are concentrated along the East Fork of the Dennison Fork of the Fortymile river and include felsic tuffs, dacites, and rhyolites. The porphyritic granite is a fault-bound unit located west of the Oreo Mountain porphyry copper-molybdenum prospect in the Tanacross B-2 Quadrangle, $13 \mathrm{~km}$ east of Ladue River, and is characterized by large potassium feldspar phenocrysts in a medium-grained groundmass consisting of quartz, feldspar, hornblende, and biotite. Unit IKgd dikes and stocks outcrop in the area between the Taurus and Oreo prospects and can be compared compositionally to quartz-feldspar porphyry (Kqp), Taurus granodiorite (Ktgd), and Pika diorite $(\mathrm{Kpd})$ in the Northeast Tanacross geologic map area (figs. 4B-6, Wypych and others, 2021). The Late Cretaceous felsic rocks exhibit high $\mathrm{SiO}_{2}$ concentrations, from 66.0 to 77.6 weight percent, with one exception of 62.5 weight percent (figs. 5A and B). They are calc-alkalic, magnesian, and largely metaluminous (figs. 5C-E), except for the peraluminous volcanic rocks (IKfv) (fig. 5E). Unit IKfv is highly siliceous; we have observed only a couple of such high-silica rhyolites in the Northeast Tanacross map area and there we assigned them to volcanic rocks unit $\mathrm{Kv}$ (Wypych and others, 2021). The trace-element composition of IKfv generally overlaps that of the 
other felsic samples (figs. 6A-F) and is comparable to that of the most siliceous Kv samples (Wypych, 2021). Late Cretaceous porphyritic granite (IKpg) is characterized by its elevated magnesian character compared to other igneous rocks of similar silica composition in the map area (fig. 5D). Similar to IKav, unit IKpg has trace-element characteristics similar to Kv from the Northeast Tanacross

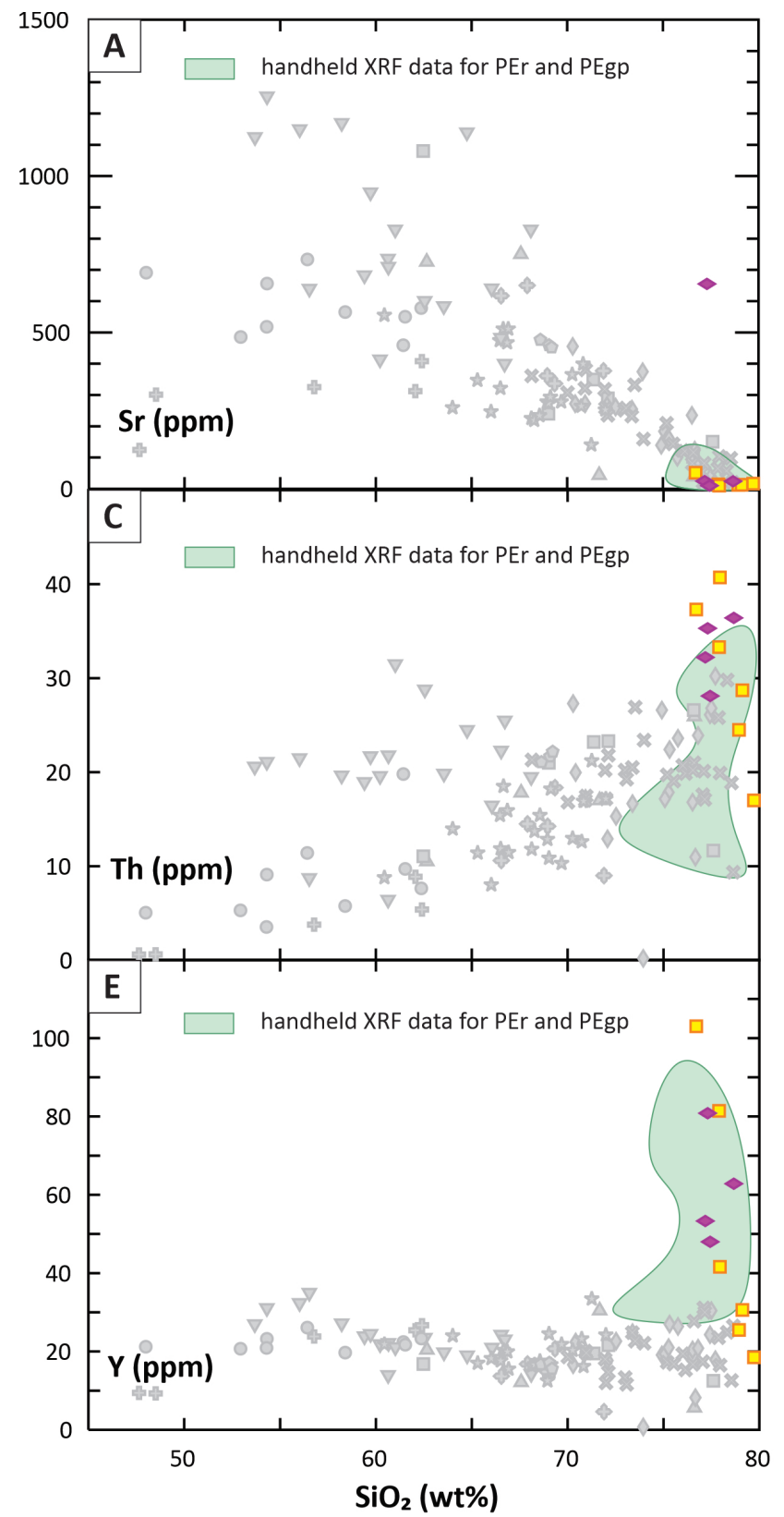

map area (figs. 6A-F). In terms of major-element composition, unit IKgd follows the Ktgd unit of the Northeast Tanacross map area (Wypych, 2021). However, the trace element composition of unit IKgd suggests a better correlation to the Pika diorite (Kpd) unit in the Northeast Tanacross map area (figs. 6A-F). This unit has lower lanthanum (La), Th, and Eu than most Ktgd (figs. 6B-D), and lower

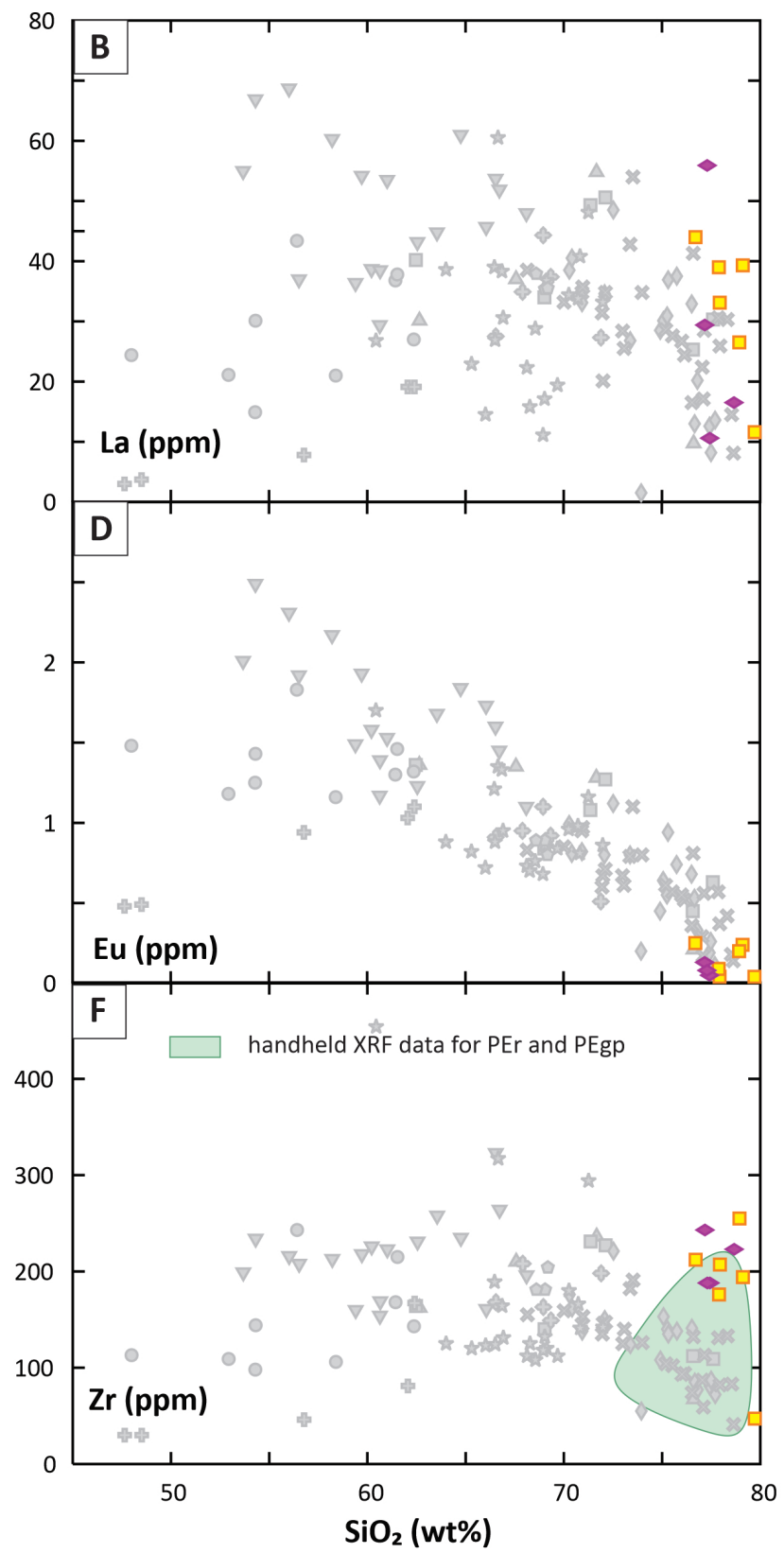

Figure 3. Bivariate plots of $\mathrm{SiO}_{2}$ (wt.\%) vs. selected trace element abundances (ppm). Symbols and colors as in figure 2, pale green polygons represent major- and trace-element data collected using hand-held XRF for Paleogene rocks. 

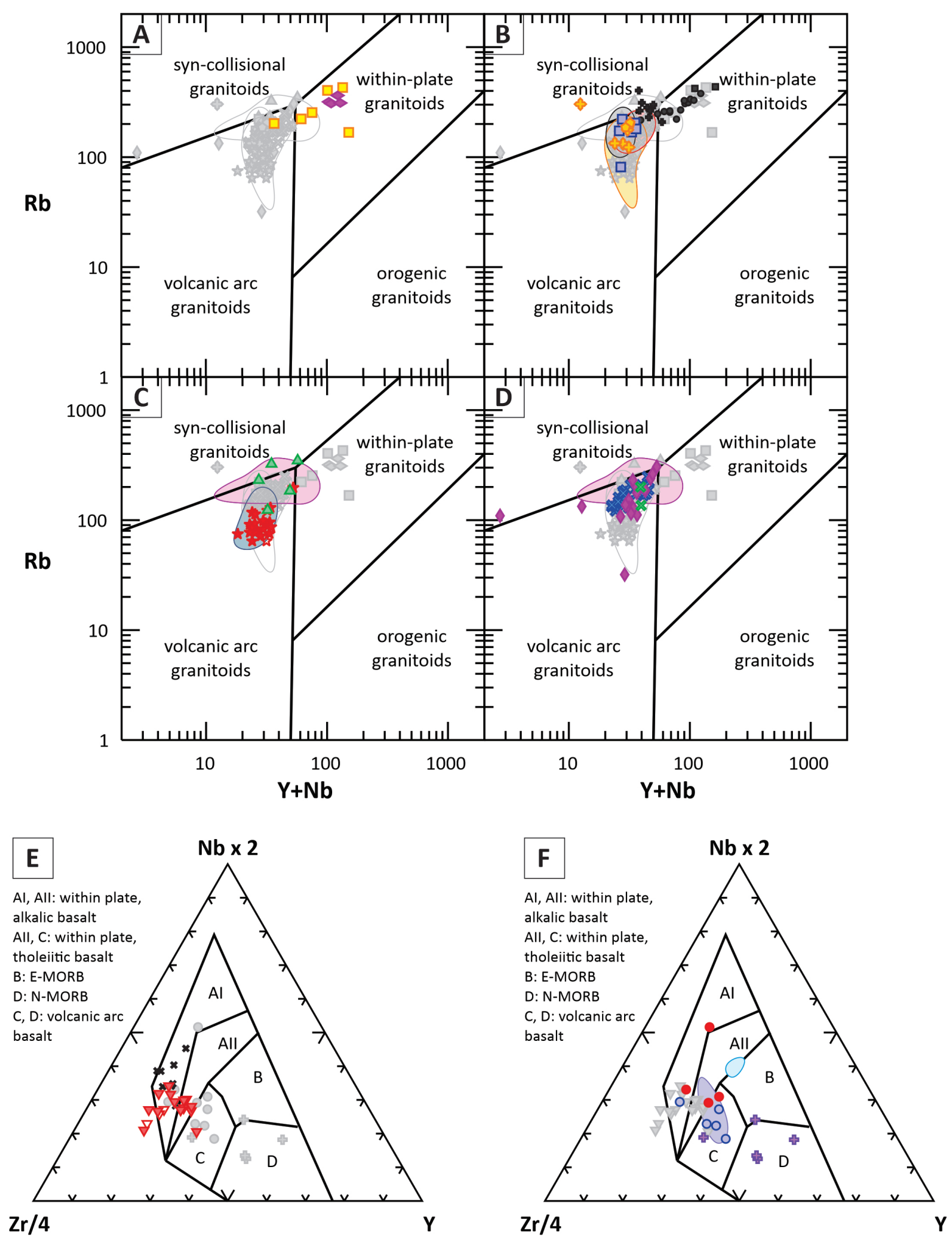

Figure 4. Tectonic classification diagrams for felsic igneous rocks from the Ladue River-Mount Fairplay area after Pearce and others (1984) for: (A) Paleogene rocks; (B) Late Cretaceous granitoids; (C) mid-Cretaceous volcanic rocks of McArthur Creek area (Kmv) area and granodiorite (Kgd); and (D) mid-Cretaceous West Fork felsic tuff (Kwff), granite porphyry (Kgp) and granite $(\mathrm{Kg})$; (E) high field-strength element, tectonic discrimination ternary diagram for Late Cretaceous mafic rocks (after Meschede, 1986); and (F) high field-strength element, tectonic discrimination ternary diagram for mid-Cretaceous mafic rocks (after Meschede, 1986). 

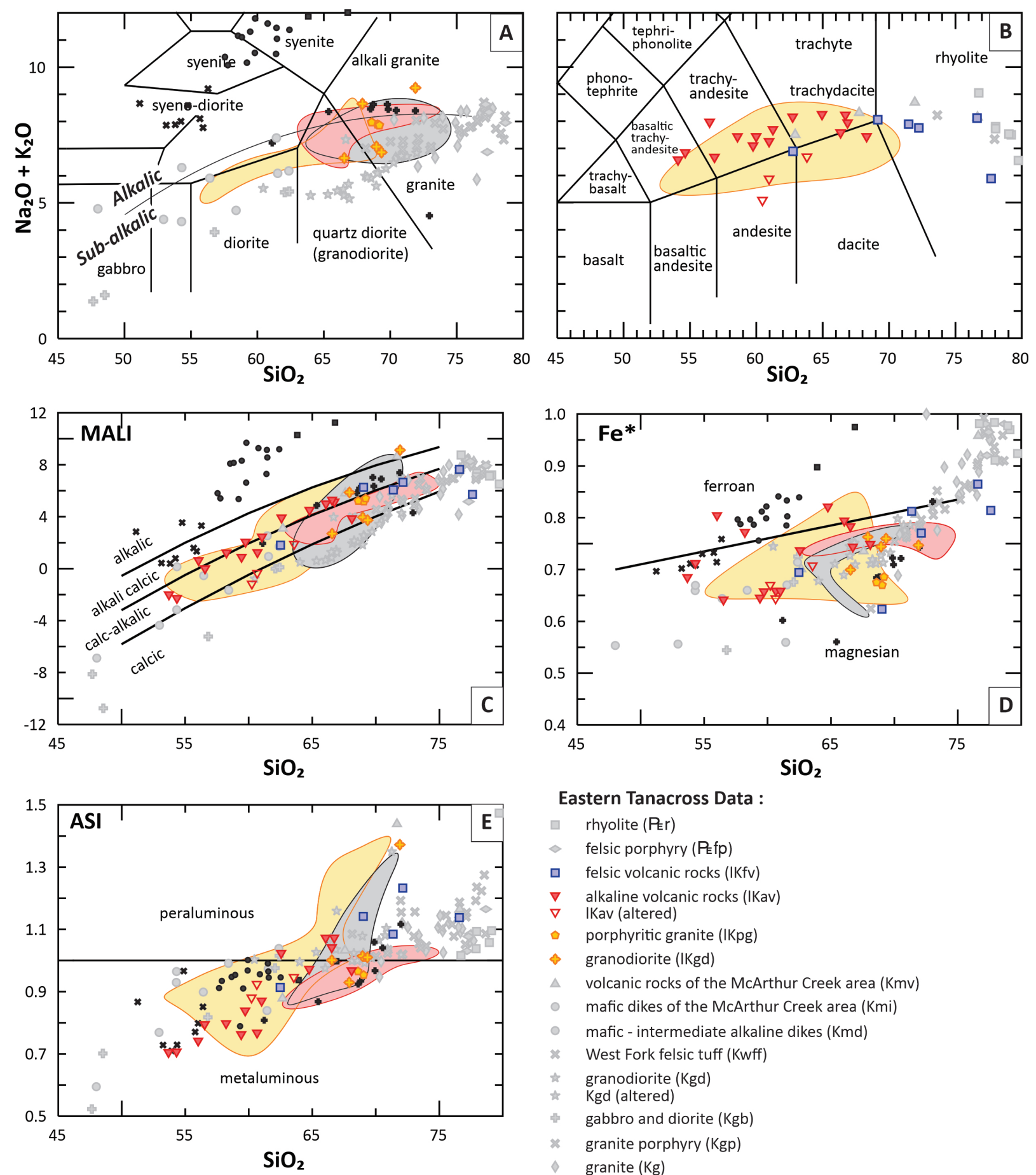

Eastern Tanacross Data :

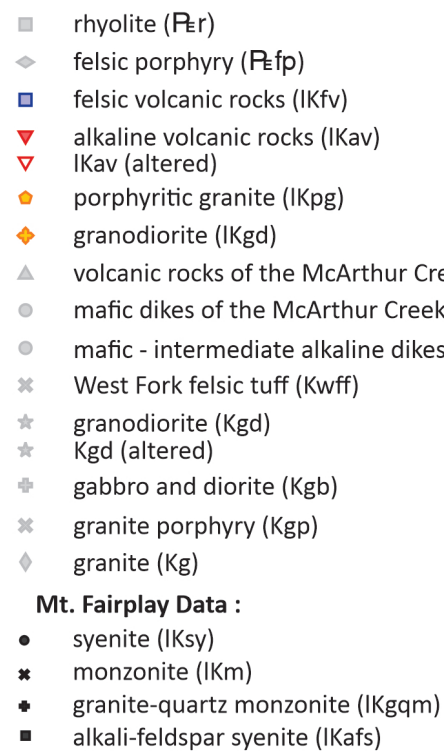

Figure 5. Classification diagrams for Late Cretaceous igneous rocks from the Ladue River-Mount Fairplay area. A. TAS showing the compositional range of the plutonic rocks. B. TAS showing the compositional range of the volcanic rocks and dikes. C. $\mathrm{MALI}=\mathrm{Na}_{2} \mathrm{O}+\mathrm{K}_{2} \mathrm{O}-\mathrm{CaO}$; Frost and others (2001). D. $\mathrm{Fe}^{* *}=\left(\mathrm{FeO}_{\text {tot }}\right) /\left(\mathrm{FeO}_{\mathrm{tot}}+\mathrm{MgO}\right) ;$ Frost and others (2001). E. ASI $\mathrm{ASI}=\mathrm{Al} /(\mathrm{Ca}-1.67 \mathrm{P}+\mathrm{Na}+\mathrm{K})$; Frost and others (2001). Oxide data have been normalized to 100-percent anhydrous. Open symbols signify samples described (in the field by the collector) as "altered;" closed symbols represent samples described as "unaltered" or "fresh." 
Sr than Kqp (fig. 6A). All the above late Cretaceous intrusive units, as well as the felsic volcanic rocks, have $\mathrm{Nb}$ plus $\mathrm{Y}$ and $\mathrm{Rb}$ concentrations characteristic of volcanic-arc granitoids (fig. 4B).

Alkaline volcanic rocks (IKav) are basaltic trachyandesite to trachydacite lava flows and tuffs, with $\mathrm{SiO}_{2}$ composition between 51 and 66 weight percent, and total alkali between 5 and 8 weight percent. This group is mainly alkali-calcic, magnesian, and metaluminous, however, a few samples display calc-alkalic, ferroan, and peraluminous compositions (figs. 5B-E). This group generally follows major element composition of the volcanic rocks observed in the Northeast Tanacross map area (Kv, figs. 5B-F) but trace elements are distinct. The elevated La, Th, and Zr (figs. 6B, C, and F) distinguishes this unit from any Late Cretaceous unit mapped in the Ladue River-Mount Fairplay map area. This unit is unique as it clearly has within-plate tectonic affiliation, as highlighted on the $\mathrm{Zr}-\mathrm{Y}-\mathrm{Nb}$ classification triangle for mafic rocks (fig. 4E).

The units of Mount Fairplay complex outcrop about $85 \mathrm{~km}$ north from Alaska Highway junction along the Taylor Highway, and are often porphyritic, with large feldspar phenocrysts in a mediumto-coarse-grained matrix. They are largely mafic, ranging from 50 to 67 weight percent $\mathrm{SiO}_{2}$, with the exception of granite-quartz monzonite (unit IKgqm), which has 69 to 76 weight percent $\mathrm{SiO}_{2}$, and generally forms a different trend than the rest of complex, resembling more closely other Late Cretaceous units of the region (figs. 5A-E). Granite-quartz monzonite and part of monzonite (IKm) unit are alkali-calcic and magnesian, whereas the syenite and alkali-feldspar syenite (IKsy and IKafs) are strongly alkalic and ferroan (figs. 5C and D), all the Mount Fairplay units are metaluminous, except for a few samples from the granite-quartz monzonite (fig. 5E). The high-alkali units also have distinctive trace element patterns from all other igneous units, particularly visible in the $\mathrm{Sr}, \mathrm{La}, \mathrm{Th}$, and $\mathrm{Zr}$ concentrations (figs. 6A-C and F). Those elements are elevated in the units, with $\mathrm{Sr}$ reaching $1,655 \mathrm{ppm}, 261 \mathrm{ppm}$ of Th, and 1,030 ppm of
Zr (figs. 6A, C, and F; Wypych and others, 2019). The granite-quartz monzonite, on the other hand, follow the late Cretaceous unit trends (figs. 6A-E) apart from slightly elevated $\mathrm{Zr}$ (fig. 6F). The syenites are characterized by largely within-plate chemical composition, and the granite-quartz monzonite is of volcanic-arc with some syn-collisional affinity samples present (figs. 4B and E).

\section{MID-CRETACEOUS IGNEOUS ROCKS}

The mid-Cretaceous igneous rocks in the Eastern Tanacross geologic map area are extensive and include volcanic rocks and dikes of the McArthur Creek area (Kmv and $\mathrm{Kmi})$, mafic to intermediate alkaline dikes (Kmd), the West Fork Tuff (Kwff), granodiorite and gabbro and diorite (Kgd and $\mathrm{Kgb}$ ), and granite porphyry and granite (Kgp and $\mathrm{Kg}$, fig. 1). The units observed in the map area are much more diverse in terms of textures, ages, and geochemical composition than the mid-Cretaceous rocks observed in our Northeast Tanacross map area (Kg; Wypych and others, 2021) and range between 45 and 78 weight percent $\mathrm{SiO}_{2}$ (figs. 7A and B). Like $\mathrm{Kmi}$, the alkaline dikes (Kmd) intrude the large granodiorite (Kgd) batholith in the southern quadrant of the map area. Rhyolite to dacite West Fork tuffs and flows (Kwff) cover a very large area in the northwest quadrant of the map area, and granite porphyry (Kgp) and granite $(\mathrm{Kg})$ are mainly observed just south of Kwff. Because of extensive weathering and alteration in the tuffaceous Kwff unit, only two fresh samples were available to analyze by commercial lab whole-rock methods.

The McArthur Creek volcanic rocks (Kmv) are characterized by alkali-calcic, ferroan, and peraluminous major-element compositions (figs. 7C-F). Other ferroan and peraluminous units in the region, such as granite $(\mathrm{Kg})$, granite porphyry (Kgp), and West Fork tuffs and flows (Kwff), are generally calc-alkalic. The mafic dikes $(\mathrm{Kmi})$ are calcic to calc-alkalic, magnesian, and metaluminous and are less alkalic than the alkaline dikes (Kmd, figs. 7C-E). The most calcic groups, Kgd and $\mathrm{Kgb}$, are magnesian. Unit $\mathrm{Kgd}$ is peraluminous and closely resembles the Moosehorn Range gran- 
odiorite (unit MRG; Joyce, 2002), and gabbro and diorite $(\mathrm{Kgb})$ are metaluminous and similar to the mafic dikes (Kmi, figs. 7C-E).

Trace-element compositions of the mid-Cretaceous units vary, but the correlation of some of the elements with silica suggest fractionation trends, such as plagioclase fractionation highlighted by the silica versus Sr plot (fig. 8A). Unit Kmv is characterized by bimodal Sr composition: the samples

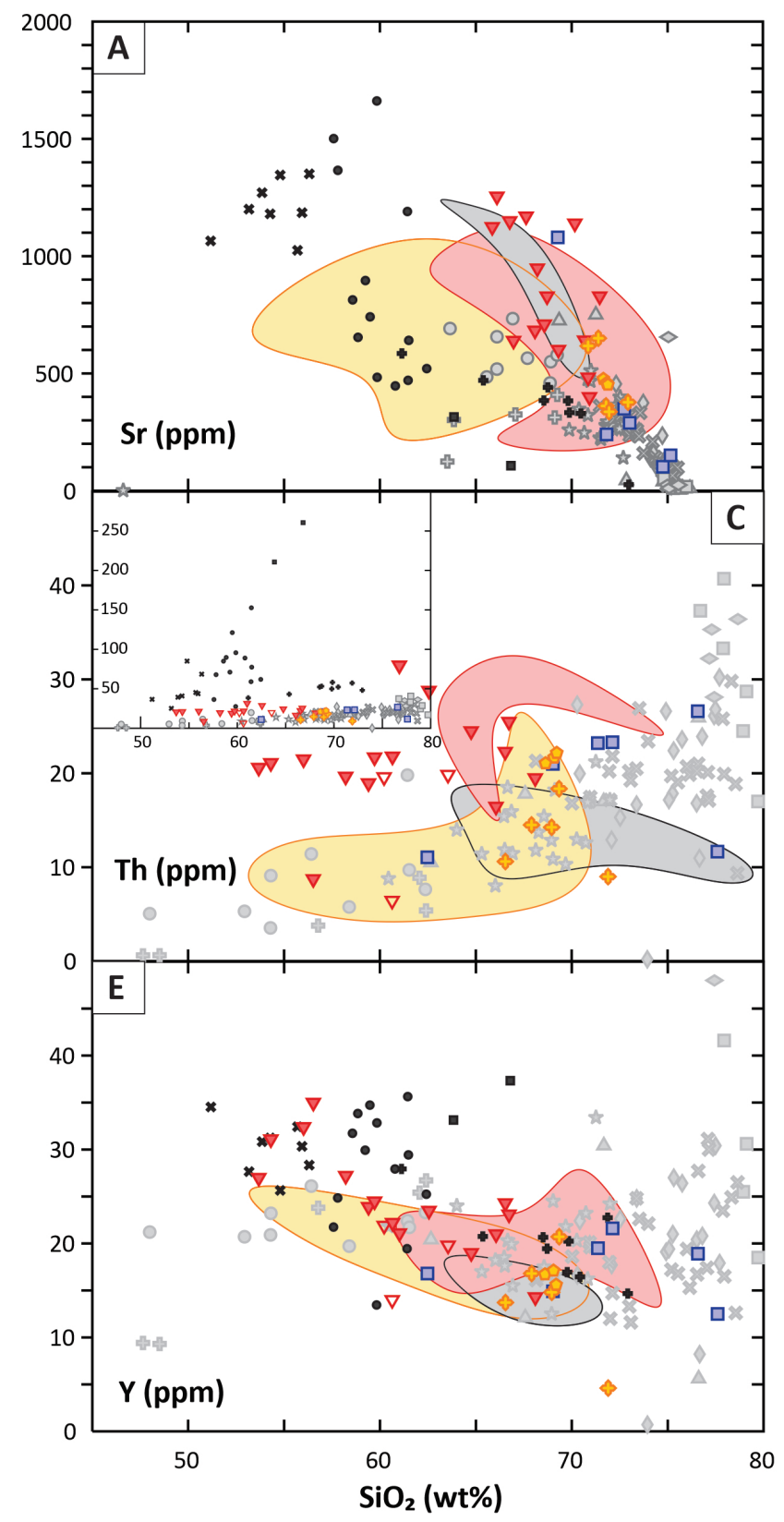

with $\mathrm{SiO}_{2}$ below 70 weight percent have higher Sr concentration-up to $750 \mathrm{ppm}$ - than other mid-Cretaceous samples, whereas the higher silica samples have a low $\mathrm{Sr}$ concentration-38 ppm (fig. $8 \mathrm{~A})$. The mafic dikes of Kmi have cohesive trace-element compositions (figs. 8A-F) comparable to other mid-Cretaceous mafic igneous rocks, but lower than the Moosehorn Range mafic dikes of Joyce (2002), highlighted by La, Eu, and Y plots

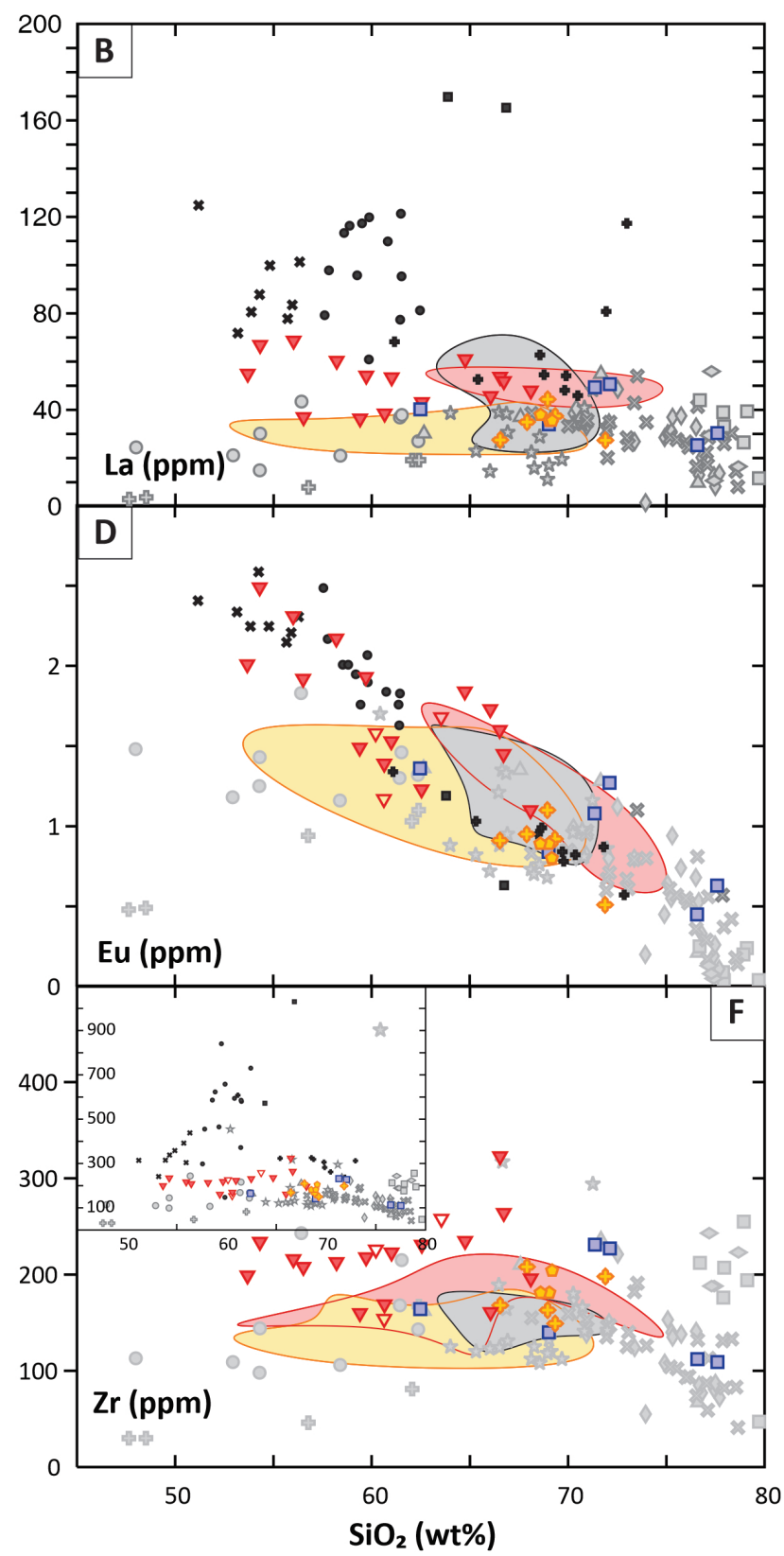

Figure 6. Bivariate plots of $\mathrm{SiO}_{2}$ (wt.\%) vs. selected trace element abundances (ppm). Symbols and colors as in figure 5; insets in $\mathrm{C}$ and $\mathrm{F}$ show an expanded $\mathrm{y}$-axis scale to accommodate Th- and Zr-rich Mount Fairplay samples. 

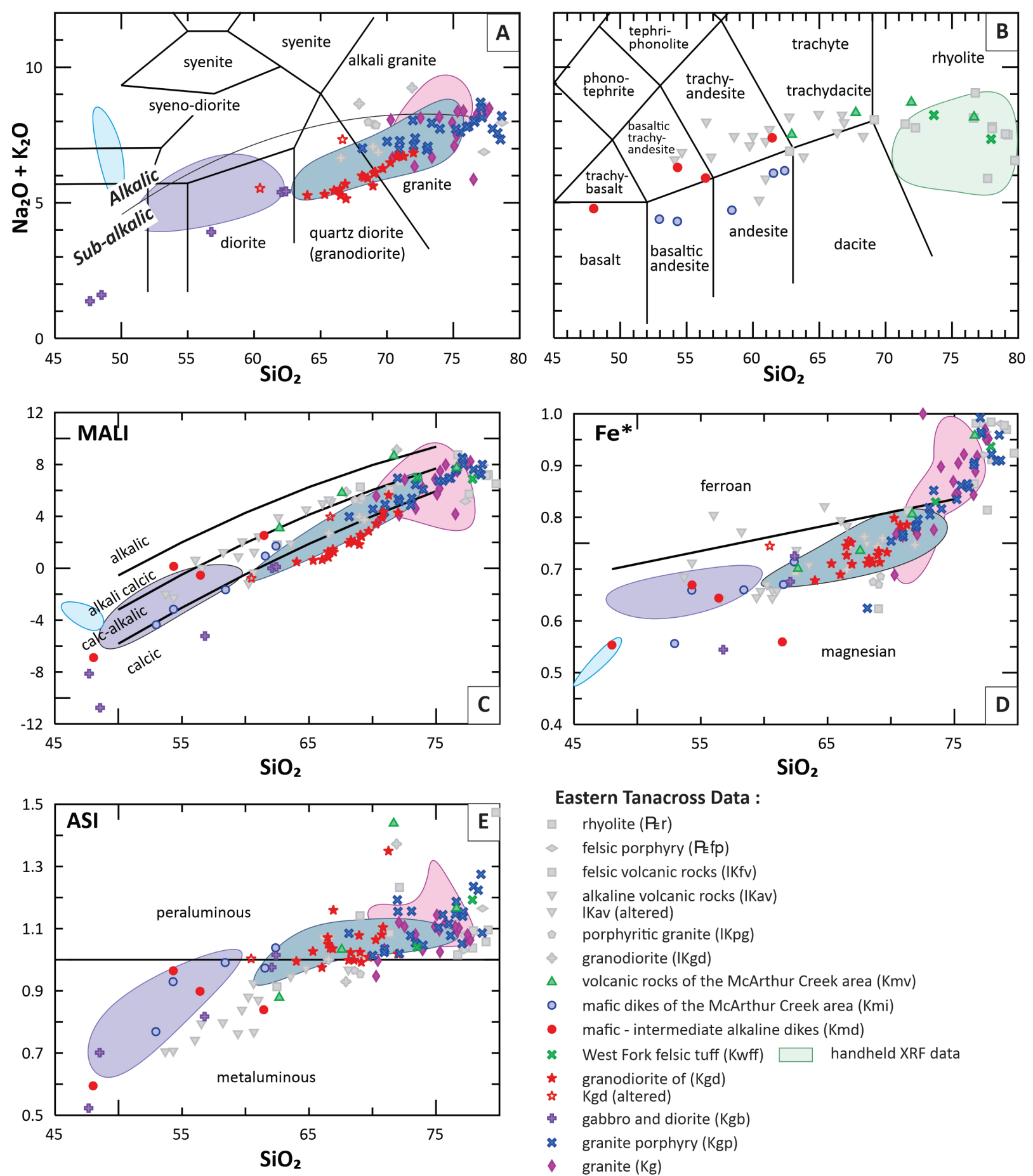

Eastern Tanacross Data :

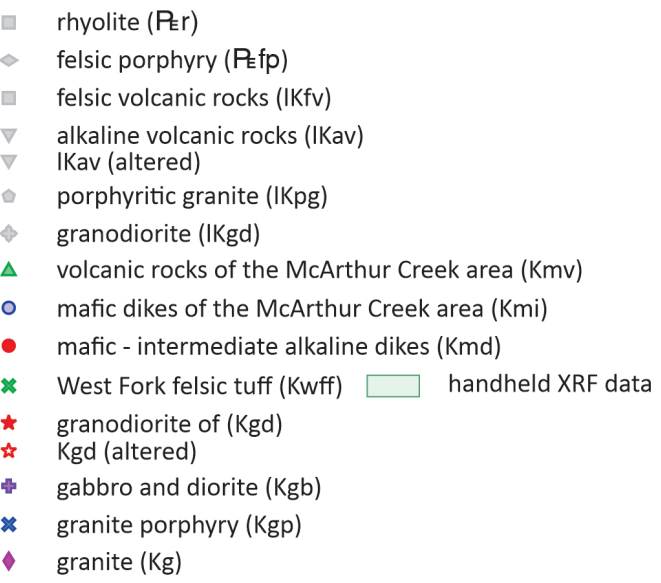

Northeast Tanacorss Data :

Moosehorn Range Data (Joyce 2002) :

granite (Kg)

Moosehorn Range granodiorite mafic dikes

lamprophyre dikes

Figure 7. Classification diagrams for mid-Cretaceous igneous rocks from the Ladue River-Mount Fairplay area. A. TAS showing the compositional range of the plutonic rocks. B. TAS showing the compositional range of the volcanic rocks and dikes. C. $\mathrm{MALI}=\mathrm{Na}_{2} \mathrm{O}+\mathrm{K}_{2} \mathrm{O}-\mathrm{CaO}$; Frost and others (2001). D. $\mathrm{Fe}^{* *}=\left(\mathrm{FeO}_{\text {tot }}\right) /\left(\mathrm{FeO}_{\text {tot }}+\mathrm{MgO}\right)$; Frost and others (2001). E. ASI $\mathrm{ASI}=\mathrm{Al} /(\mathrm{Ca}-1.67 \mathrm{P}+\mathrm{Na}+\mathrm{K})$; Frost and others (2001). Oxide data have been normalized to 100-percent anhydrous. Open symbols signify samples described (in the field by the collector) as "altered;" closed symbols represent samples described as "unaltered" or "fresh." 
(figs. 8 B,D, and E). Unit Kmd can be differentiated from the McArthur Creek mafic dikes (Kmi) by elevated $\mathrm{Sr}, \mathrm{La}, \mathrm{Th}, \mathrm{Eu}$, and $\mathrm{Zr}$ (figs. 8A-D and $\mathrm{F}$ ), and other light rare earth elements (Wypych and others, 2019). Unit Kgd is generally on trend with the MRG samples (figs. 8A-F) but differs from most of the other mid-Cretaceous igneous rocks. This is particularly well illustrated by $\mathrm{SiO}_{2}$ versus Zr plot (fig. 8F), where the granodiorite forms a separate trend. The gabbros have low trace element concentrations, except $\mathrm{Y}$ and $\mathrm{Eu}$ in a couple of more evolved, higher silica samples (figs. 8D and E). Trace element composition of $\mathrm{Kpg}$ and $\mathrm{Kg}$ are in agreement with the Kg unit of the Northeast Tanacross map area (Wypych, 2021), but separate fractionation trends on Zr plots (fig. 8F) suggest differences in zircon fractionation between the two units.

The diversity in trace-element composition in the mid-Cretaceous rocks is reflected in the tectonic classification diagrams (figs. $4 \mathrm{C}, \mathrm{D}$, and F). The majority of the units are characterized by volcanic-arc granitoid signatures, however, part of the $\mathrm{Kmv}$ group and two $\mathrm{Kg}$ samples have syn-collisional signatures; a sample from Kgb plots in the E-MORB field, and Kmd has a within-plate affinity (figs. 4C and F). In the Northeast Tanacross map area, we observed syn-collisional as well as within-plate granitoids within the Kg group (Wypych, 2021).

\section{CONCLUSIONS}

The unmetamorphosed magmatic units in the Ladue River-Mount Fairplay map area span from mid-Cretaceous to Paleogene time. Most of the Cretaceous igneous activity is volcanic-arc related (figs. 4B-D). The magnesian signature of most samples supports magma genesis under oxidized conditions (Frost and Frost, 2008). A few ferroan exceptions are the high-silica Paleogene rhyolites and porphyries ( $P_{E}, P_{E} f p$ ) and mid-Cretaceous syenite (IKsy), alkali-feldspar syenite (IKafs), and granite and granitic porphyry (Kg and Kgp units), as well as some samples from unit IKav. Late Cretaceous syenite (IKsy), alkali-feldspar syenite (IKafs,), and alkali volcanic rocks form unit IKav, as well as the Paleogene units, have distinctive "within-plate" signatures (figs. 4A and E). In mid-Cretaceous samples, this signature is observed in unit Kmd (fig. 4F), whereas siliceous samples from the McArthur Creek area have syn-collisional trace element compositions (fig. 4C). The change in geochemical signature between Cretaceous and Paleogene igneous rocks marks a change in the tectonic regime. Mid-Cretaceous extensional faulting and a ca. 115 Ma northeast-dipping subduction zone (Hansen and Dusel-Bacon, 1998; Dusel-Bacon and others, 2002, 2015) are responsible for the within-plate and volcanic-arc signatures observed in the oldest igneous rocks of eastern Tanacross (Allan and others, 2013). The Late Cretaceous magmatic pulse has a similar mixture of volcanic-arc and within-plate trace-element compositions. The Paleogene rocks display within-plate trace-element signatures almost exclusively and are highly evolved. In other parts of eastern interior Alaska, this magmatism is bimodal (Bacon and others, 1990; Foster and others, 1994; Newberry and others, 1996). The presence of alkaline Late Cretaceous rocks and Paleogene bimodal volcanism in the region suggests onset of regional extension in the Late Cretaceous and continuing into the Paleogene (Dusel-Bacon and others, 2009, 2015).

\section{ACKNOWLEDGMENTS}

The author would like to thank the DGGS Mineral Resources section field geologists and other DGGS staff who contributed to this data collection, scientific discussions, and other support.

This project was jointly funded by the State of Alaska and the U.S. Geological Survey's Earth Mapping Resources Initiative (Earth MRI) through cooperative agreement G19AC00262. The views and conclusions contained in this document are those of the authors and should not be interpreted as representing the opinions or policies of the U.S. Geological Survey. Mention of trade names or commercial products does not constitute their endorsement by the U.S. Geological Survey. 

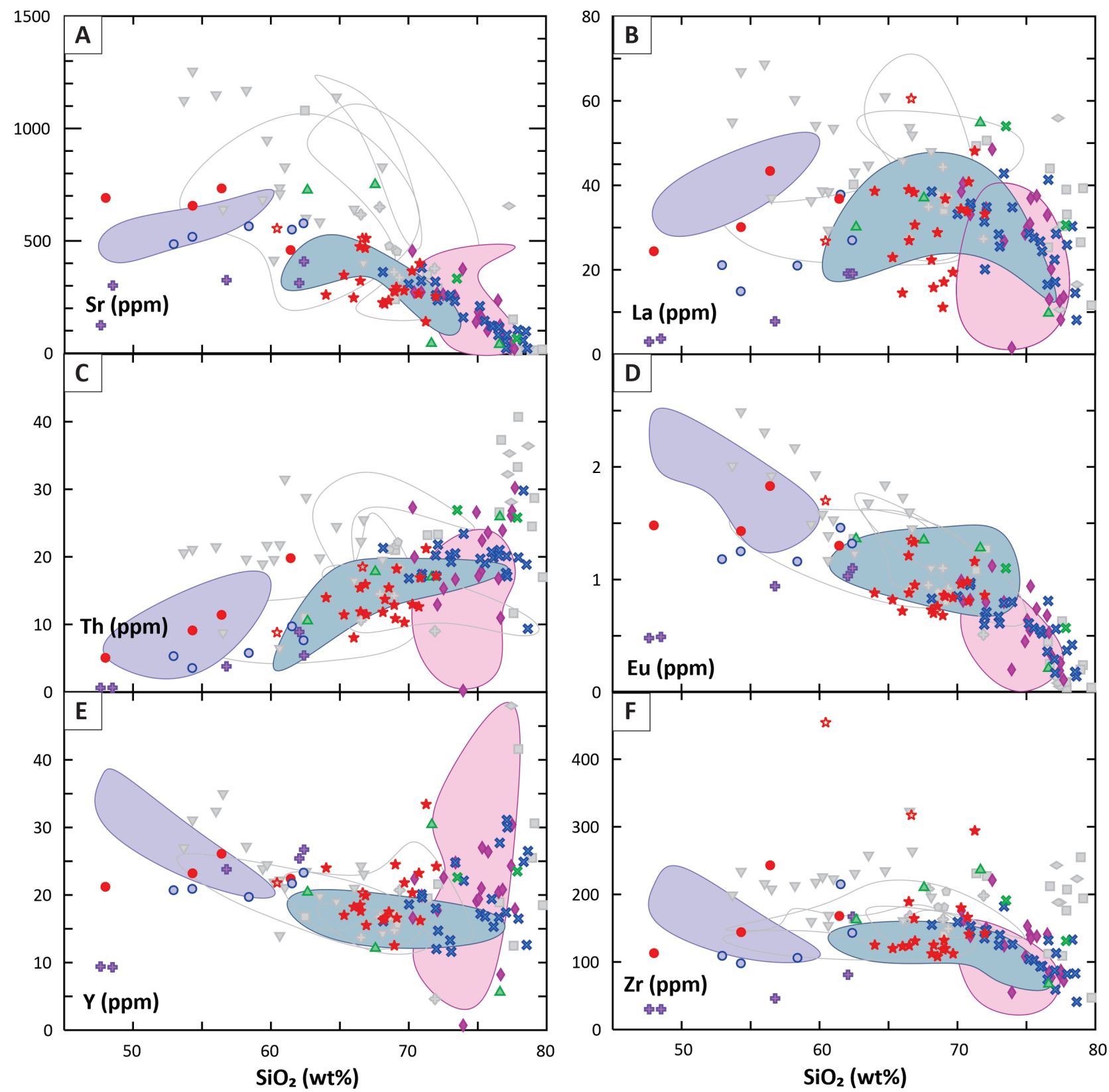

Figure 8. Bivariate plots of $\mathrm{SiO} 2$ (wt.\%) vs selected trace element abundances (ppm). Symbols and colors as in figure 7.

\section{REFERENCES}

Allan, M.M., Mortensen, J.K., Hart, C.R, Bailey, L.A., Sanchez, M.G., Ciolkiewicz, Wiltold, McKenzie, G.G., and Creaser, R.A., 2013, Magmatic and metallogenic framework of west-central Yukon and eastern Alaska, in Colpron, Maurice, Bissig, Thomas, Rusk, B.G., and Thompson,
J.F.H., Tectonics, Metallogeny, and Discovery: The North American Cordillera and Similar Accretionary Settings: Society of Economic Geologists, Special Publication 17, p. 111-168.

Bacon, C.R., Foster, H.L., and Smith, J.G., 1990, Rhyolitic calderas of the Yukon-Tanana terrane, east- central Alaska-Volcanic remnants of a midCretaceous magmatic arc: Journal of Geophysical 
Research, v. 95, no. B13, p. 21,451-21,461.

Dusel-Bacon, Cynthia, Aleinikoff, J.N., Day, W.C., and Mortensen, J.K., 2015, Mesozoic magmatism and timing of epigenetic $\mathrm{Pb}-\mathrm{Zn}-\mathrm{Ag}$ mineralization in the western Fortymile mining district, east-central Alaska: Zircon U-Pb geochronology, whole-rock geochemistry, and $\mathrm{Pb}$ isotopes: Geosphere, v. 11, no. 3, p. 786-822.

Dusel-Bacon, Cynthia, Lanphere, M.A., Sharp, W.D., Layer, P.W., and Hansen, V.L., 2002, Mesozoic thermal history and timing of structural events for the Yukon-Tanana Upland, eastcentral Alaska: ${ }^{40} \mathrm{Ar} /{ }^{39} \mathrm{Ar}$ data from metamorphic and plutonic rocks: Canadian Journal of Earth Sciences, v. 39, no. 6, p. 1,013-1,051. http://doi. org/10.1139/e02-018

Dusel-Bacon, Cynthia, Slack, J.F., Aleinikoff, J.N., and Mortensen, J.K., 2009, Mesozoic magmatism and base-metal mineralization in the Fortymile mining district, eastern Alaska-initial results of petrographic, geochemical, and isotopic studies in the Mount Veta area: Studies by the U.S. Geological Survey in Alaska, 2007: U.S. Geological Survey Professional Paper 1760-A, p. 1-42.

Foster, H.L., 1967, Geology of the Mount Fairplay area, Alaska: U.S. Geological Survey Bulletin 1241-B, p. B1-B18, 1 sheet, scale 1:63,360.

Foster, H.L., 1970, Reconnaissance geologic map of the Tanacross Quadrangle, Alaska: U.S. Geological Survey Miscellaneous Geologic Investigations Map 593, 1 sheet, scale 1:250,000.

Foster, H.L., Keith, T.E.C., and Menzie, W.D., 1994, Geology of the Yukon-Tanana area of east-central Alaska, in Plafker, George, and Berg, H.C., eds., The Geology of Alaska, v. G-1 of The Geology of North America: Boulder, Colorado, Geological Society of America, p. 205-240.

Frost, B.R., Barnes, C.G., Collins, W.J., Arculus, R.J., Ellis, D.J., and Frost, C.D., 2001, A geochemical classification for granitic rocks: Journal of Petrology, v. 42, no. 11, p. 2,033-2,048.

Frost, B.R., and Frost, C.D., 2008, A Geochemical Classification for Feldspathic Igneous Rocks: Journal of Petrology, v. 49, no. 11, p. 1,955-1,969.

Hansen, V.L., and Dusel-Bacon, Cynthia, 1998, Structural and kinematic evolution of the Yukon-Tanana Upland tectonites, east-central Alas-
ka-A record of late Paleozoic to Mesozoic crustal assembly: Geological Society of America Bulletin v. 110 , no. 2, p. 211-230.

Harrington, Edward, 2010, Technical report on the Taurus property, Fairbanks Recording District, Alaska, U.S.A.: Unpublished NI43-101 report for Senator Minerals Inc., $133 \mathrm{p}$.

Joyce, N.L., 2002, Geologic setting, nature, and structural evolution of intrusion-hosted Au-bearing quartz veins at the Longline occurrence, Moosehorn Range area, west-central Yukon Territory: Unpublished Master's thesis, University of British Columbia, Vancouver, Canada. 199 p.

Kreiner, D.C., Jones III, J.V., Todd, Erin, Holm-Denoma, Chris, Caine, J.S., Benowitz, J.A., 2019, Links between tectonics, magmatism, and mineralization in the formation of Late Cretaceous porphyry systems in the Yukon-Tanana upland, eastern Alaska, USA: Proceedings of the 15th biennial meeting for geology applied to mineral deposits, p. 939-942.

LeBas, M.J., LeMaitre, R.W., Streckeisen, Albert, and Zanettin, Bruno, 1986, A Chemical Classification of Volcanic Rocks Based on the Total Alkali-Silica Diagram: Journal of Petrology, v. 23, no. 3, p. 745-750.

Lerich, P.D., 1995, Taurus copper-molybdenum porphyry deposit, east-central Alaska, in Schroeter, T.G., ed., Porphyry Deposits of the Northwestern Cordillera of North America: Canadian Institute of Mining Metallurgy and Petroleum Special Volume 46, p. 451-457.

Meschede, Martin, 1986, A method of discrimination between different types of mid-ocean ridge basalts and continental tholeiites with the $\mathrm{Nb}-\mathrm{Zr}-\mathrm{Y}$ diagram: Chemical Geology, v. 56, p. 207-218.

Newberry, R.J., 2020, The Mount Fairplay igneous complex: Alaska Division of Geological \& Geophysical Surveys Preliminary Interpretive Report 2020-1, 32 p. https://doi.org/10.14509/30463

Newberry, R.J., Bundtzen, T.K., Clautice, K.H., Combellick, R.A., Douglas, Tom, Laird, G.M., Liss, S.A., Pinney, D.S., Reifenstuhl, R.R., and Solie, D.N., 1996, Preliminary geologic map of the Fairbanks mining district, Alaska: Alaska Division of Geological \& Geophysical Surveys Public Data File 96-16, 17 p., 2 sheets, scale 
1:63,360. https://doi.org/10.14509/1740

Pearce, J.A., Harris, N.B., and Tindle, A.G., 1984, Trace element discrimination diagrams for the tectonic interpretation of granitic rocks: Journal of Geophysical Research, v. 103, p. 7,171-7,186.

Szumigala, D.J., Newberry, R.J., Werdon, M.B., Athey, J.E., Stevens, D.S.P., Flynn, R.L., Clautice, K.H., and Craw, P.A., 2002, Geologic map of the Eagle A-1 Quadrangle, Fortymile mining district: Alaska Division of Geological \& Geophysical Surveys Preliminary Interpretive Report 2002-1A, 1 sheet, scale 1:63,360. https://doi. org/10.14509/2863

Twelker, Evan, Newberry, R.J., Wypych, Alicja, Naibert, T.J., Wildland, A.D., Sicard, K.R., Regan, S.P., Athey, J.E., Wyatt, W.C., and Lopez, J.A., 2021, Bedrock geologic map of the Ladue River-Mount Fairplay area, Tanacross and Nabesna quadrangles, Alaska, in Twelker, Evan, ed., Geologic investigation of the Ladue River-Mount Fairplay area, eastern Alaska: Alaska Division of Geological \& Geophysical Surveys Report of Investigation 2021-5A. https://doi. org/10.14509/30735

Twelker, Evan, and Newberry, R.J., 2021, Observations on the economic geology of the northeast Tanacross map area, in Wypych, Alicja, ed., Northeast Tanacross geologic mapping project, Alaska: Alaska Division of Geological \& Geophysical Surveys Report of Investigation 2020-9F. https://doi.org/10.14509/30557

Werdon, M.B., Newberry, R.J., Szumigala, D.J., and Pinney, D.S., 2001, Geologic map of the Eagle A-2 Quadrangle, Fortymile mining district, Alaska: Alaska Division of Geological \& Geophysical Surveys Preliminary Interpretive Report 2001-3A, 1 sheet, scale 1:63,360, v. 1.0.1. https://doi.org/10.14509/2669

Wilson, Marjorie, 1989, Igneous petrogenesis A Global Tectonic Approach: Unwin Hyman, London, $416 \mathrm{p}$.

Wypych, Alicja, Twelker, Evan, Naibert, T.J., Athey, J.E., Newberry, R.J., Lopez, J.A., Regan, S.P., Sicard, K.R., Wildland, A.D., and Wyatt, W.C., 2019, Major-oxide and trace-element geochemical data from rocks collected in 2019 for the Eastern Tanacross project, Tanacross and part of Nabesna quadrangles, Alaska: Alaska Division of Geological \& Geophysical Surveys Raw Data File 2019-8, 3 p. https://doi.org/10.14509/30267 Wypych, Alicja, Hubbard, T.D., Naibert, T.J., Athey, J.E., Newberry, R.J., Sicard, K.R., Twelker, Evan, Werdon, M.B., Willingham, A.L., Wyatt, W.C., and Lockett, A.C., 2021, Northeast Tanacross geologic map and map units and descriptions, in Wypych, Alicja, ed., Northeast Tanacross geologic mapping project, Alaska: Alaska Division of Geological \& Geophysical Surveys Report of Investigation 2020-9B. https://doi.org/10.14509/30539 Wypych, Alicja, 2021, Geochemical interpretation of samples of igneous rocks from northeast Tanacross, in Wypych, Alicja, Northeast Tanacross geologic mapping project, Alaska: Alaska Division of Geological \& Geophysical Surveys Report of Investigation 2020-9E. https://doi. org/10.14509/30542 


\section{CHAPTER F: ECONOMIC GEOLOGY OF THE LADUE RIVER- MOUNT FAIRPLAY AREA}

Evan Twelker ${ }^{1}$

\section{INTRODUCTION}

The Ladue River-Mount Fairplay map area hosts a variety of prospects and occurrences related to several different mineral systems active in discrete phases during the Permian, middle Cretaceous, and latest Cretaceous-early Paleogene (fig. 1). Basemetal soil anomalies and local massive sulfide at the Ladue prospect group occur within the Klondike assemblage and may represent a Permian volcanogenic massive sulfide system. Voluminous felsic to intermediate magmatism at around 110-100 Ma is associated with only limited magmatic-hydro-

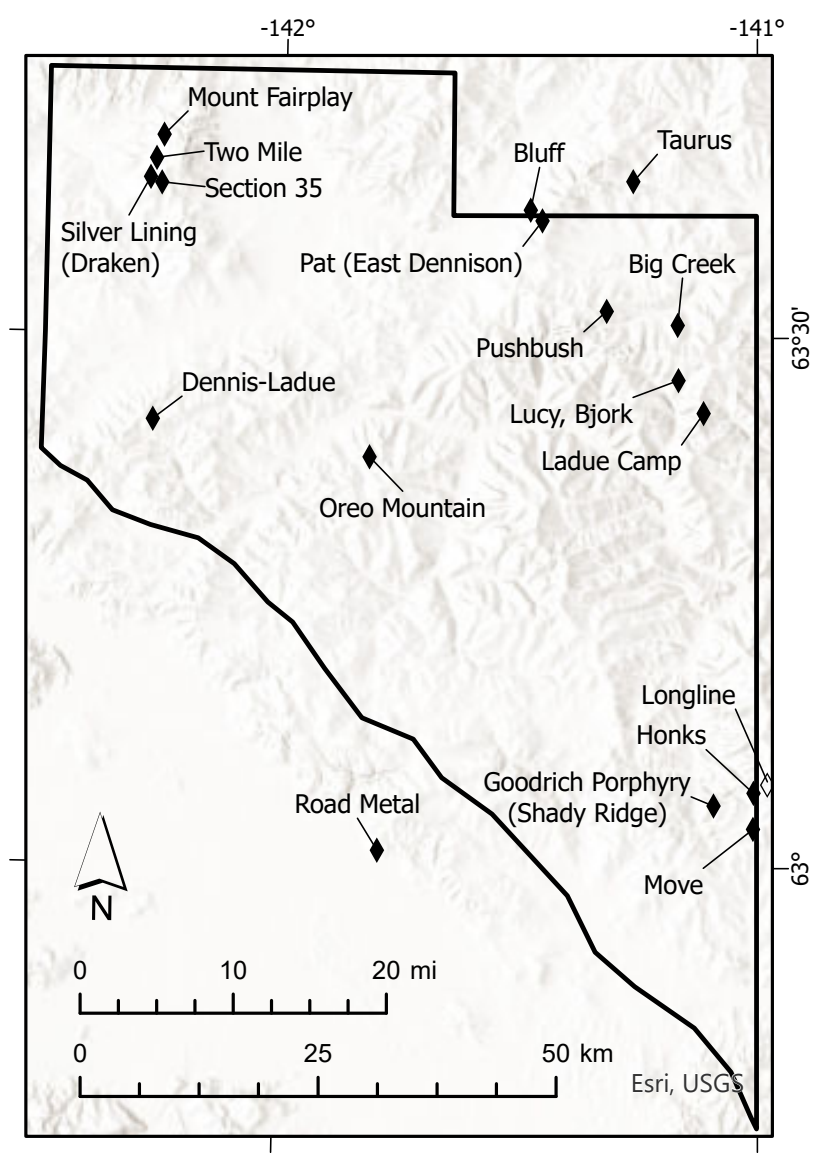

Figure 1. Map illustrating the locations of prospects mentioned in this chapter. thermal mineralization, such as the incompletely understood Pushbush and Dennis-Ladue prospects. Polymetallic and precious-metals-bearing mineralization in the Moosehorn Range (Honks, Goodrich Porphyry, and Move prospects; Longline gold deposit in Yukon) is hosted within a mid-Cretaceous granodiorite batholith but, at ca. $93 \mathrm{Ma}$, mineralization at the Longline deposit postdates magmatism and contains lead sourced from the metamorphic country rock rather than the host plutonic rocks (Joyce, 2002). Latest Cretaceous (71-66 Ma) intrusions of intermediate, sub-alkaline composition have the greatest metallogenic significance; regionally, they are associated with the Manh Choh (formerly Peak/Tetlin) gold-silvercopper $(\mathrm{Au}-\mathrm{Ag}-\mathrm{Cu})$ skarn deposit, the East Taurus copper-molybdenum (Cu-Mo) porphyry deposit, and the Road Metal polymetallic intrusion-related prospect. Within the map area, Oreo Mountain is an early stage $\mathrm{Cu}-\mathrm{Mo}$ porphyry prospect, while Pat may be a satellite of the broader Taurus-Bluff porphyry system. Alkaline intrusions at Mount Fairplay (Section 35 prospect) are locally enriched in uranium, thorium, rare earth elements, niobium, and zirconium (U-Th-REE-Nb-Zr).

\section{Stratabound Mineralization Hosted by Paleozoic Rocks}

\section{Ladue Prospect Group (Bjork, Ladue Camp)}

The Ladue prospect group, including the Ladue Camp and Bjork (also known as Lucy) prospects, were discovered by Cities Service Minerals Corporation in 1976 during regional exploration for porphyry $\mathrm{Cu}-\mathrm{Mo}$ systems. The prospects have basemetal soil anomalies (up to 2,100 parts per million [ppm] lead [Pb], 2,550 ppm zinc [Zn], and 331 ppm Cu; Cities Service Minerals Corp., 1980) and

${ }^{1}$ Alaska Division of Geological \& Geophysical Surveys, 3354 College Rd., Fairbanks, Alaska 99709-3707 
are associated with metamorphosed mafic and felsic volcanic rocks and carbonaceous sedimentary rocks. These features led to the exploration of the property as a potential syngenetic base-metal mineral system. Subsequent exploration of the heavily covered area relied on airborne and ground-based electromagnetic (EM) geophysical surveys. Cities Service tested a coincident EM and geochemical anomaly at Ladue Camp with a 197-m (645-foot) diamond drill hole, intercepting "several thin bands of massive sulfide" within graphite schist (unit Pkgs), terminating in meta-andesite (also known in industry reports as greenschist; probably unit $\mathrm{Pkmb}$ of this report); the company concluded that the graphitic schist was the source of the EM anomaly (Cities Service, 1980). U.S. Borax reached a similar conclusion after 1978-1979 exploration work at the Bjork prospect, including three shallow 29- to 34-m-long (95- to 110-foot) drill holes, which encountered greenschist (chlorite-actinolite schist) with graphitic schist interbeds. U.S. Borax concluded that the geochemical anomaly arose from disseminated chalcopyrite, galena, and sphalerite in the local metamorphic rocks (Henricksen and Ashleman, 1980). Noranda explored the Lucy (Bjork) claims in 1982, confirming anomalous $\mathrm{Cu}, \mathrm{Pb}$, and $\mathrm{Zn}$ enrichment in soils in a weakly conductive horizon lying at the transition between mafic metavolcanics rocks and the overlying graphitic metasedimentary rocks (Dunbier, 1980).

\section{Big Creek}

The Big Creek prospect is underlain by greenschist and interlayered siliceous, micaceous, and graphitic schists of the Klondike assemblage (units Pkmb and Pks). Cities Service Minerals Corporation staked the prospect in 1976 following discovery of a strong $\mathrm{Cu}-\mathrm{Zn}-\mathrm{Pb}-\mathrm{Ag}-\mathrm{Au}$ soil geochemical anomaly. Follow-up work by Cities Service and U.S. Borax (1978-1979) included further sampling, geophysical surveying, and shallow core drilling using a "Winkie" field-portable core drill. The drilling encountered greenschist and sericite schist but failed to identify the source of the soil anomaly. Trace pyrite was observed throughout much of the core. Cuttings from the core drilling were sampled at 10-foot intervals and were largely below detection; however, one interval assayed 450 ppm $\mathrm{Cu}$ and 108 ppm Mo (Henricksen and Ashleman, 1980). This geochemical result suggests porphyry $\mathrm{Cu}-\mathrm{Mo}$ mineralization (similar in style to the Taurus prospect $17 \mathrm{~km}$ to the north), but there are no corresponding geological observations (such as porphyry dikes, porphyry-style alteration, $\mathrm{Cu}$ or Mo-sulfide-bearing quartz veinlets) from core or surface to support this interpretation.

\section{Mid-Cretaceous Mineral Systems Pushbush}

DGGS geologists visited and sampled the Pushbush prospect but did not have access to any reports beyond the brief descriptions of Singer and others (1976; site 11) and Eberlein and others (1977; page 102). The Alaska Resource Data File (U.S. Geological Survey, 2018) references two drill holes, but we were unable to confirm these in the field or the literature. Our examination of the prospect located a single trench exposing molybdenite-bearing quartz veinlets hosted by silicified and sericitized gneiss, plus local disseminated pyrite and chalcopyrite. We mapped two igneous units in the prospect vicinity, mid-Cretaceous porphyry (assigned to unit Kmi) and Paleogene rhyolite dikes or volcanic rocks (assigned to unit PEfp). A sample of the unit Kmi, quartz-veined and brecciated quartz-feldspar-biotite porphyry, carried minor disseminated pyrite and chalcopyrite; it was the only DGGS sample from the prospect that carried anomalous $\mathrm{Cu}(305 \mathrm{ppm} \mathrm{Cu}$; sample 19ET102 of Wypych and others, 2019). Feldspar phenocrysts are altered to sericite and biotite phenocrysts are altered to chlorite. U-Pb zircon dating of this sample yielded an age of 110.7 $\pm 2.5 \mathrm{Ma}$ (sample 19ET102; Wildland and others, 2021). Unit Pefp rhyolite occurs throughout the prospect area; it carries up to 1 percent pyrite and has a weakly altered appearance, but it was found to be barren of $\mathrm{Cu}-\mathrm{Mo}$ mineralization (Wypych and others, 2019). A sample of this unit from the prospect area yielded a $\mathrm{U}-\mathrm{Pb}$ zircon age of $57.1 \pm$ 1.2 Ma (19KS100; Wildland and others, 2021). 


\section{Dennis-Ladue}

The Dennis-Ladue prospect comprises quartz veins, vein breccias, and intense silicification associated with a composite felsic stock (USGS, 2018, and references therein), which we infer based on our mapping to be mid-Cretaceous granite porphyry (unit Kgp). DGGS sampled vuggy quartz-sulfide vein material in the general prospect vicinity ( 40 parts per billion $[\mathrm{ppb}]$ gold and weakly anomalous arsenic (As); sample 19ET209 of Wypych and others, 2019), but did not otherwise succeed in relocating the prospect. The Dennis-Ladue prospect lies on land belonging to Doyon Limited.

\section{Moosehorn Ridge Area}

Mineralization in the Moosehorn Ridge area comprises multiple mineralization styles of probable mid-Cretaceous age. The district is bisected by the Alaska-Yukon border, with the Canadian portion having seen higher levels of placer gold production, exploration interest, and scientific study. Joyce (2002) completed a detailed economic geology study of the Longline gold deposit (5 $\mathrm{km}$ east of the Goodrich Porphyry prospect), concluding, based on $\mathrm{Pb}$-isotopic evidence, that the metals in the veins were not derived from the mid-Cretaceous intrusions that dominate local bedrock. By extension, we believe that future work on the Alaska portion of the Moosehorn Ridge area, including the Goodrich Porphyry prospect, should consider an orogenic origin for the mineralization in addition to the magmatic-hydrothermal model suggested by the associated intrusive host rocks.

\section{Goodrich Porphyry (Shady Ridge)}

Porphyry $\mathrm{Cu}-\mathrm{Mo}$ exploration by Cities Services Minerals Corporation during the late 1970's resulted in the discovery of the Shady Ridge prospect, a greater than one-kilometer-diameter $\mathrm{Cu}-$ Mo-Zn-Ag soil anomaly. This anomaly was rediscovered by Blue Moose Exploration (BME) in the early 2000s and explored as the Goodrich Porphyry prospect. BME and 2010 joint-venture partner Millrock Resources, Inc., conducted extensive soil sampling in the area, trenched across the Goodrich
Porphyry, and drilled 33 shallow churn drill holes to access bedrock below frozen cover. Rock sampling results reported by BME indicate locally high values of many elements, as illustrated by one trench grab sample assaying $195 \mathrm{ppm} \mathrm{Mo,} 10.3 \mathrm{ppm} \mathrm{Ag,} 337$ ppm Cu, 3677 ppm Pb, 693 ppm Zn, 128 ppm As, $213 \mathrm{ppm}$ antimony $(\mathrm{Sb})$, and $2.59 \mathrm{ppm}$ mercury (Hg) (Blue Moose Exploration, 2015). The prospect geology, as synthesized during a brief visit by DGGS, is characterized by granodiorite country rock (unit Kgd) intruded by mid-Cretaceous felsic to intermediate dikes (unit Kma). A gouge-filled, northeast-trending fault transects the soil anomaly and is well exposed in the trench. Mo-enriched samples collected by DGGS are pervasively weathered and iron oxide-stained granodiorite cut by quartz veinlets (19ET014 and 19ET015 of Wypych and others [2019]); if present, sericitic or argillic alteration is impossible to differentiate from weathering. Felsic dikes were barren of mineralization despite being locally veined, iron-stained, and possibly altered to sericitic or argillic assemblages.

\section{Honks}

The Honks gold prospect lies about $4 \mathrm{~km}$ (2.5 miles) east of the Goodrich Porphyry prospect. It comprises gold-bearing quartz veins cutting granodiorite (unit $\mathrm{Kgd}$ ); andesite dikes occur in the vicinity but have uncertain relationship to the mineralization. The prospect was explored by BME and trenched and sampled under joint venture with Millrock Resources. Trenches visited by DGGS showed vuggy, quartz-pyrite-arsenopyrite veinlets several centimeters thick with sericitized margins; granodiorite away from the veinlets was unaltered (19JEA007; Wypych and others, 2019). Trench sampling by Millrock returned numerous mineralized samples grading $0.1-0.5 \mathrm{ppm} \mathrm{Au}, 1-8 \mathrm{ppm} \mathrm{Ag}$, greater than 1 percent As, 5-340 ppm bismuth (Bi), and 10-26 ppm Sb (Blue Moose Exploration, 2015). $\mathrm{An}{ }^{40} \mathrm{Ar} /{ }^{39} \mathrm{Ar}$ age for the sericite is pending, however, the mineralization is thought to be mid-Cretaceous based on similarities to mineralization at the Longline deposit $1.5 \mathrm{~km}$ to the east on the Yukon side of the Alaska-Canada border, where muscovite from 
gold-bearing veins yielded ${ }^{40} \mathrm{Ar} /{ }^{39} \mathrm{Ar}$ ages around 93 Ma (Joyce, 2002).

The creek immediately south of the Honks prospect hosts a placer gold deposit characterized by minimally transported, delicate wire and crystalline gold (site 14 of Singer and others, 1976). In 1990, Canada Tungsten conducted a placer gold drill program that defined a resource of 5,880 ounces of gold in 325,784 cubic yards of material. In 2010, a small placer mining operation exploited this resource (Blue Moose Exploration, 2015).

\section{Move}

Public records describe the Move prospect as an early-stage lode gold exploration property (U.S. Geological Survey, 2018; Eberlein and others, 1977). DGGS did not have access to any detailed information on this prospect, however, we visited a trench in the general vicinity of the ARDF location prospect and found vuggy, iron- and $\mathrm{Cu}-\mathrm{ox}-$ ide-stained quartz veinlets cutting granodiorite (unit Kgd). A grab sample of this material assayed $35.8 \mathrm{ppm} \mathrm{Ag}, 63 \mathrm{ppb} \mathrm{Au}, 64 \mathrm{ppm}$ As, $315 \mathrm{ppm}$ $\mathrm{Pb}$, and $749 \mathrm{ppm} \mathrm{Zn}$ (19TJN004; Wypych and others, 2019); as such, this prospect may be similar to the Honks and Goodrich Porphyry prospects described above, as well as the Longline prospect described by Joyce (2002).

\section{LATE CRETACEOUS-EARLY PALEOGENE MINERAL SYSTEMS}

\section{Oreo Mountain}

Cities Service Minerals Corporation discovered the Oreo Mountain Cu-Mo prospect in 1976 during follow-up work on soil anomalies generated by regional exploration the previous year. The prospect remained known as a poorly exposed, approximately $4-\mathrm{km}$ by $1.5-\mathrm{km} \mathrm{Cu}-\mathrm{Mo}-\mathrm{Ag}$ soil anomaly until 2007 when Full Metal Minerals re-staked the prospect and conducted a few years of surface work. In 2011, DGGS published an airborne magnetic and electromagnetic survey of the Ladue area (Burns and others, 2020) showing a strong aeromagnetic anomaly associated with the area of the Oreo prospect. In 2018, Tubutulik Mining Company re-staked the prospect and optioned it to Kennecott Exploration. Kennecott completed additional surface work, including soil sampling and trenching, and, in 2019 drilled six diamond drill holes ranging in depth from 150 to $186 \mathrm{~m}$ (fig. 2). All six holes encountered broad intercepts of low-grade $\mathrm{Cu}$ mineralization, and strong Mo mineralization was encountered in parts of several holes (Kennecott Exploration, 2019).

$\mathrm{Cu}-\mathrm{Mo}$ mineralization intercepted at Oreo is hosted mostly within a medium-grained, magnetite-bearing granodiorite (Kennecott Exploration, 2019), which we assign to the Late Cretaceous granodiorite unit ( $\mathrm{Kgd}$ ) of this map. A DGGS surface sample of granodiorite porphyry with disseminated chalcopyrite yielded a U-Pb zircon age of $71.4 \pm 0.2$ $\mathrm{Ma}$ (19TJN243), and a second sample of altered intrusive rock from the prospect trench area yielded an age of $72.1 \pm 1.6 \mathrm{Ma}$ (19RN282; Wildland and others, 2021). A large body of coarse-grained, K-feldspar porphyritic granite (unit $1 \mathrm{Kpg}$ ) outcrops on the ridges to the south and west, separated from the prospect by a west-northwesterly trending fault (fig. 2). This intrusion projects under mineralization and was intersected below the granodiorite $(\mathrm{lKgd})$ at the end of many of the drill holes; it is locally altered but essentially barren. U-Pb zircon dating of the K-feldspar-porphyritic granite indicates an age of $68.8 \pm 1.5 \mathrm{Ma}$, slightly younger than the granodiorite porphyry intrusions associated with mineralization (sample 19RN287; Wildland and others, 2021). Kennecott Exploration (2019) also observed veined and mineralized diorite xenoliths within both granodiorite and K-feldspar porphyritic granite intrusions. Finally, drilling intercepted barren, apparently post-mineralization rhyolite dikes cutting mineralized granodiorite (Kennecott Exploration, 2019); we interpret these as corresponding to spherulitic rhyolite (PEfp) sampled from surface in the prospect area, dated at $58.6 \pm 1.4 \mathrm{Ma}$ (sample 19ET277; Wildland and others, 2021).

Mineralization was observed in granodiorite and the adjacent metamorphic country rock, and it occurs primarily as thin quartz and K-feldspar veinlets with pyrite \pm chalcopyrite \pm bornite 


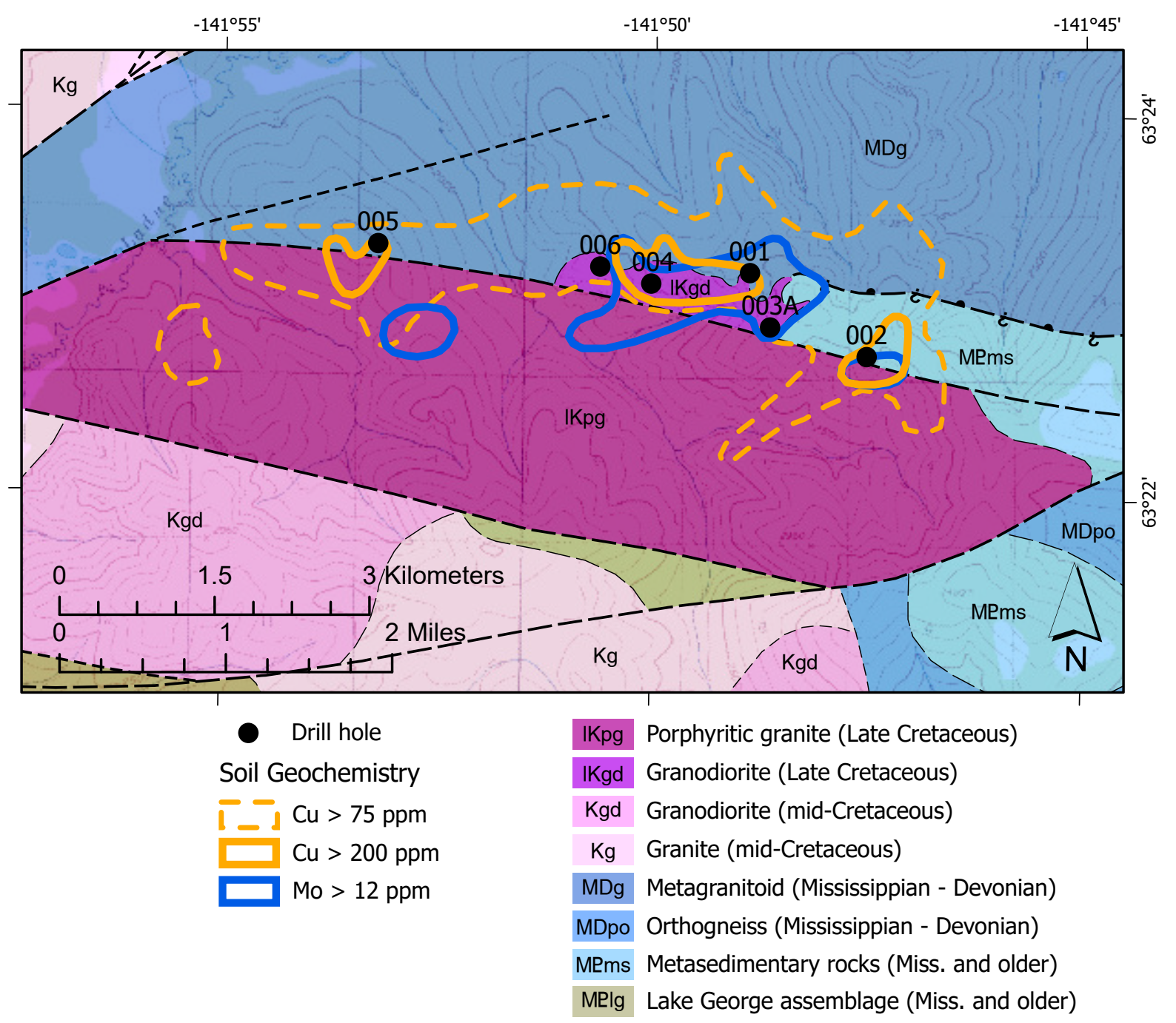

Figure 2. Oreo prospect $\mathrm{Cu}$ and Mo soil anomalies and 2019 drill hole locations (Kennecott Exploration, 2019; Hedderly-Smith, 2020) plotted with DGGS geologic map (this study).

\pm magnetite; disseminated pyrite and chalcopyrite were found locally (fig. 3). Molybdenite was observed primarily in veinlets. Alteration includes potassic assemblages of K-feldspar and biotite associated mainly with veinlets and vein selvages; zones of strong molybdenite mineralization were associated with increased potassic alteration. One drill hole intercepted a broad zone of moderate, magnetite-destructive sericite and/or clay alteration accompanying (or overprinting) veinlet-hosted quartz-pyrite-chalcopyrite-molybdenite-magnetite mineralization. Other alteration includes chlorite-sericite and propylitic assemblages affecting both intrusive and metamorphic country rocks (Kennecott Exploration, 2019).

\section{Pat Claims}

Cities Service Minerals Corporation located the Pat (also known as East Dennison) prospect at the source of USGS stream-sediment anomalies generated by the Alaska Mineral Resource Assessment Program (AMRAP; Foster and others, 1976) in the adjacent drainages (Cities Service, 1980; Henricksen and Ashleman, 1980). Cities Service and U.S. Borax completed prospecting and sampling work in the late 1970s; Kenorland Minerals conducted surface sampling in 2018 and included the prospect in a property-wide airborne time-domain EM survey (Werdon and others, 2021). As described by Henricksen and Ashleman (1980) and confirmed by DGGS during 2018 

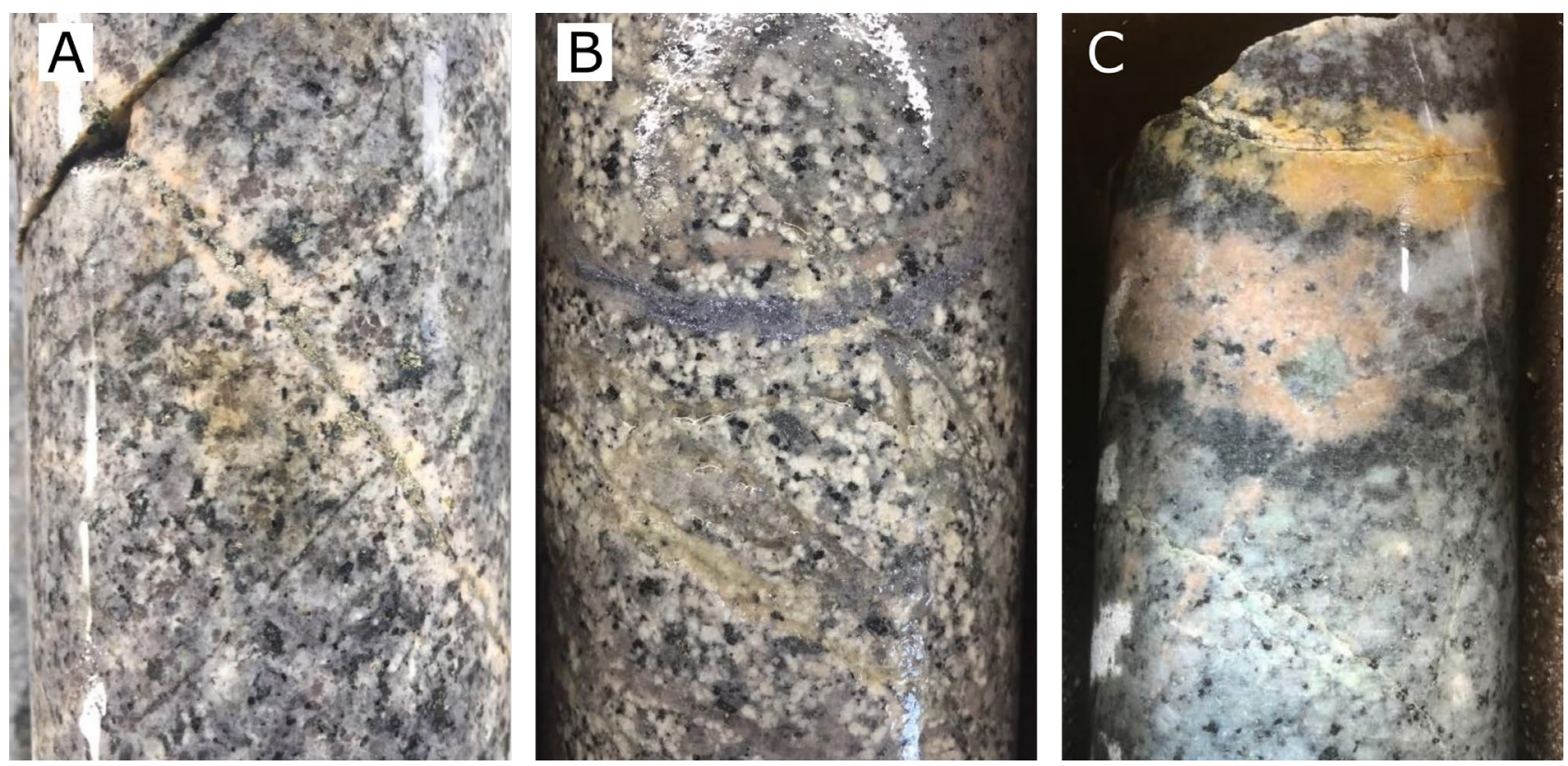

Figure 3. Drill core photographs of mineralization and potassic alteration at the Oreo prospect. A. Quartz-pyrite-molybdenite-chalcopyrite \pm magnetite veins with K-feldspar alteration selvage (drill hole OREO-001). B. Quartz-molybdenite mineralization in granodiorite (drill hole OREO-003A). C. Quartz-K-feldspar vein with molybdenite, pyrite, magnetite, and chalcopyrite; vein selvage is secondary biotite (drill hole OREO-003A). Host rock in all photos is Late Cretaceous granodiorite, unit IKgd. All photos and descriptions are from Kennecott Exploration (2019).

fieldwork, the prospect is hosted by Mesozoic intrusive rock (herein mapped as Late Cretaceous granodiorite, unit $1 \mathrm{Kgd}$ ) intruding gneiss of the Lake George assemblage. Mineralization comprises quartz \pm tourmaline \pm pyrite veins, breccias, and pervasive, texturally destructive tourmaline-sericite replacements within the intrusive rock and at its contact with the gneiss. Samples of this style of mineralization are enriched in $\mathrm{Ag}-\mathrm{Pb}-\mathrm{Bi}-\mathrm{As}-\mathrm{Sb}$; DGGS sampling returned $\mathrm{Ag}$ values up to 10.15 ppm (18KS095, Wypych and others, 2018). Cities Service (1980) described the tourmaline-bearing veins as associated with a northeast-trending fault that controls similar alteration to the Taurus area. Locally intense sericite alteration at the prospect yielded an ${ }^{40} \mathrm{Ar} /{ }^{39} \mathrm{Ar}$ age of $65.8 \mathrm{Ma}$ (Doug C. Kreiner [U.S. Geological Survey], personal commun., 2018).

\section{Mount Fairplay}

The Mount Fairplay prospect lies immediately north of the Mount Fairplay alkalic intrusive complex. Reconnaissance and surface exploration has been undertaken by several companies since the 1970s, including Cities Service Minerals Corporation, Bear Creek Mining Company, Kerr McGee, RAA, and WGM (Kerin, 1976; Adams, 2009). DGGS sampling during 2019 located one or more granite porphyry dikes (unit IKfd) intruding augen orthogneiss (unit MDag). As mapped, these dikes are separated from the alkalic plutonic rocks by a north-side-down high-angle fault of unknown displacement. The granite porphyry contains $1-5$ percent disseminated or veinlet-hosted pyrite, as well as disseminated rosettes or veinlets of tourmaline. Weak to moderate sericitic alteration and minor silicification also are present. Geochemical results show sporadic enrichment in a variety of elements, including up to $46 \mathrm{ppm}$ Mo with 16.2 ppm Bi (19ET335), and 64 ppb Au with 667 ppm Cu (19RN359; Wypych and others, 2019). A sample of this intrusion yielded a U-Pb zircon age of $70.5 \pm 1.6 \mathrm{Ma}$ (19RN359; Wildland and others, 2021). 


\section{Silver Lining}

The Silver Lining prospect, also known as the Draken property, is located at milepost 30 along the Taylor Highway and is exposed by roadcuts on the uphill side of the road. It was first located in 1990 by prospectors William and Dawna DeHaven and has been explored by surface rock and soil sampling. The prospect is hosted within Late Cretaceous quartz monzonite (unit $1 \mathrm{Kgqm}$ ). As described by Adams (2009) the prospect comprises a series of widely spaced (greater than $3 \mathrm{~m}$, locally 30-60 cm), sheeted, tabular, and through-going sulfide-rich quartz veins ranging from 1 to $4 \mathrm{~cm}$ thick. The veins strike southwest, with azimuths of $215^{\circ}-240^{\circ}$ and northwesterly dips $65^{\circ}-75^{\circ}$ ). Open fractures lined with euhedral quartz are present locally; elsewhere, there is evidence for minor shearing, gouge, and slickenlines along the veins. Sulfide infill, in decreasing order of abundance, includes arsenopyrite, pyrite, galena, and chalcopyrite. Veins are crudely zoned, with arsenopyrite towards the margins and chalcopyrite along vein centers. The veins are bordered by 2 - to 30-cm-wide alteration halos of bleaching (argillic alteration), silicification, and chloritization; these halos are largely barren of gold. Selective sampling at the prospect in 2006 yielded grades as high $0.832 \mathrm{ppm} \mathrm{Au}, 65.7 \mathrm{ppm}$ $\mathrm{Ag}, 5,942 \mathrm{ppm}$ As, 170 ppm Bi, 5.09 percent $\mathrm{Cu}$, 1.42 percent $\mathrm{Pb}, 2.24$ percent tungsten $(\mathrm{W})$, and 1.17 percent Zn (Adams, 2009). Mineralization likely formed in the earliest Paleogene during the cooling of the granite-quartz monzonite pluton (lKgqm), dated at $66.5 \pm 1.1 \mathrm{Ma}$ (U-Pb zircon; Dusel-Bacon and others, 2015).

\section{Two Mile}

The Two Mile prospect lies on the Taylor Highway approximately $2 \mathrm{~km}$ north of the Silver Lining prospect. Mineralization is very similar to that at Silver Lining, except that the veins strike more northerly (azimuth $22^{\circ}$, dip $80^{\circ}$ to the east), wall rock alteration is more intense, and the values for $\mathrm{Au}$ and As are much lower. Selective sampling in 2006 returned values of 1.2 percent $\mathrm{Cu}$ and 284 ppm Mo in separate samples (Adams, 2009).

\section{Section 35}

The Section 35 occurrence, which has seen only limited surface sampling, comprises a small exposure of alkali-feldspar syenite (unit lKafs of this report; perthosite ring dike of Kerin [1976]) that is enriched in $\mathrm{U}, \mathrm{Th}, \mathrm{Nb}, \mathrm{Zr}$, and REE. DGGS sampled the occurrence in 2019, the best result being a sample carrying $125 \mathrm{ppm} \mathrm{Nb}, 1,030 \mathrm{ppm}$ Zr, 261 ppm Th, 92 ppm U, and REE including 165 ppm lanthanum, 294 ppm cerium, and 81 ppm neodymium (605 ppm total REE; 19AW318, Wypych and others, 2019); Adams (2009) found similar values. Enrichment of these elements is due to both magmatic fractionation and hydrothermal processes. Newberry (2020) examined the mineralogy of the prospect in detail, observing that primary magmatic minerals apatite and ilmenite are enriched in REE and Nb, respectively. Fine-grained secondary allanite, monazite, and cheralite occur in association with apatite that has been depleted of REE by hydrothermal alteration. The bulk of $\mathrm{Nb}$ and light REE appear to be concentrated in secondary titanite forming as an alteration product of primary mafic minerals and ilmenite. Titanite at the occurrence is notably enriched in fluorine (F), and samples from the best-mineralized alkalifeldspar syenite contain fluorite; F- and chlorine (Cl)-rich hydrothermal fluids are important to the formation of magmatic-associated REE deposits. Newberry (2020) concludes that the observed volume and intensity of $\mathrm{F}$ and $\mathrm{Cl}$ metasomatism at Mount Fairplay are limited in surface exposures, further adding that the host rocks are not of the "miaskitic" family of alkalic rocks typically associated with some REE deposits. 


\section{PROSPECT LOCATIONS}

Table 1. Best-known locations of prospects in the map area.

\begin{tabular}{lcc}
\multicolumn{1}{c}{ Prospect } & Latitude & Longitude \\
\hline Ladue Camp & 63.429 & -141.113 \\
\hline Lucy, Bjork & 63.460 & -141.166 \\
\hline Big Creek & 63.512 & -141.168 \\
\hline Goodrich Porphyry & 63.059 & -141.091 \\
(Shady Ridge) & 63.071 & -141.008 \\
\hline Honks & 63.037 & -141.009 \\
\hline Move & 63.525 & -141.318 \\
\hline Pushbush & 63.419 & -142.272 \\
\hline Dennis-Ladue & 63.386 & -141.815 \\
\hline Oreo Mountain & 63.610 & -141.455 \\
\hline Pat (East Dennison) & 63.642 & -142.262 \\
\hline Section 35 & 63.647 & -142.286 \\
\hline Silver Lining/Draken & 63.665 & -142.274 \\
\hline Two Mile & 63.687 & -142.259 \\
\hline Mount Fairplay & & \\
\hline
\end{tabular}

\section{ACKNOWLEDGMENTS}

We are indebted to the geologists and prospectors who preceded us, the people who found these prospects through extensive sampling and surveying, dug or drilled to find rock, and documented their results in detailed reports and maps. We thank Donald L. Stevens for sharing his Cities Service Minerals Corporation data collection and David A. Hedderly-Smith (Tubutulik Mining Company) for sharing the Kennecott Oreo Mountain prospect report. We thank Charles G. "Chip” Ireys for sharing his Blue Moose Exploration data and orienting us to the Moosehorn area. We are grateful to have had access to Doyon Limited lands within the study area, and we thank Doyon Vice President of Lands Jamie Marunde and consulting geologist Harold J. Noyes for their help in securing this permission. Reviews by Doug Kreiner and Cynthia Dusel-Bacon improved this report and were much appreciated.

This project was jointly funded by the State of Alaska and the U.S. Geological Survey's Earth Mapping Resources Initiative (Earth MRI) through cooperative agreement G19AC00262. The views and conclusions contained in this document are those of the authors and should not be interpreted as representing the opinions or policies of the U.S. Geological Survey. Mention of trade names or commercial products does not constitute their endorsement by the U.S. Geological Survey. 


\section{REFERENCES}

Adams, David, 2009, Geologic report on the Drakan project, Fortymile Mining District, Alaska: Technical Report DK08 43-101 for Fire River Gold Corporation, 49 p. www.sedar.com (accessed February 23, 2009)

Blue Moose Exploration, 2015, Blue Moose Exploration porphyry copper \& gold vein prospects, Moosehorn Range, Tanacross (A1) Quadrangle, Alaska: http://bluemooseexploration.com/ BME-Prospect.html (website accessed April 1, 2019; no longer available at this address)

Burns, L.E., Graham, G.R.C., Barefoot, J.D., Naibert, T.J., Fugro Airborne Surveys Corp., and Fugro GeoServices, Inc., 2020, Ladue electromagnetic and magnetic airborne geophysical survey data compilation: Alaska Division of Geological \& Geophysical Surveys Geophysical Report 2019-20, 15 p. https://doi.org/10.14509/30261

Cities Service Minerals Corporation, 1980, Data Compilation, Cities Service Company Prospects, Tanacross Quadrangle, Alaska: Unpublished report, 19 p. (Held by D.L. Stevens, Anchorage, Alaska)

Dusel-Bacon, Cynthia, Aleinikoff, J.N., Day, W.C., and Mortensen, J.K., 2015, Mesozoic magmatism and timing of epigenetic $\mathrm{Pb}-\mathrm{Zn}-\mathrm{Ag}$ mineralization in the western Fortymile mining district, east-central Alaska: Zircon U-Pb geochronology, whole-rock geochemistry, and $\mathrm{Pb}$ isotopes: Geosphere, v. 11, no. 3, https://doi. org/10.1130/GES01092.1

Cities Service Minerals Corporation, 1980, Data Compilation, Cities Service Company Prospects, Tanacross Quadrangle, Alaska: Unpublished report, 19 p. (Held by D.L. Stevens, Anchorage, Alaska)

Dunbier, John, 1982, Final report: The Ladue River Project: Unpublished report for Noranda Exploration, Inc., Anchorage, Alaska. 74 p. (Held by D.L. Stevens, Anchorage, Alaska)

Eberlein, G.D., Chapman, R.M., Foster, H.L., and Gassaway, J.S., 1977, Map and table describing known metalliferous and selected nonmetalliferous mineral deposits in central
Alaska: U.S. Geological Survey Open-File Report 77-168-D, 132 p., 1 sheet, scale 1:1,000,000.

Foster, H.L., Albert, N.R.D., Barnes, D.F., Curtin, G.C., Griscom, Andrew, Singer, D.A., and Smith, J.G., 1976, The Alaskan Mineral Resource Assessment Program; background information to accompany folio of geologic and mineral resource maps of the Tanacross Quadrangle, Alaska: U.S. Geological Survey Circular 734, 19 p.

Hedderly-Smith, D.A., 2020, The Oreo Mountain Prospect and Exploration History, Metallogenics and Current Industry Activity in the Tanacross Quadrangle, East-Central Alaska: Alaska Miners Association Annual Convention, Anchorage, Alaska, November 4, 2020, 38 p.

Henricksen, T.A. and Ashleman, J.C., 1980, Cities Service Option Final Report: Unpublished report for U.S. Borax dated March 12, 1980. 46 p. (Held by D.L. Stevens, Anchorage, Alaska)

Joyce, N.L., 2002, Geologic setting, nature, and structural evolution of intrusion-hosted Au-bearing quartz veins at the Longline occurrence, Moosehorn Range area, west-central Yukon Territory: Unpublished Master's thesis, University of British Columbia, Vancouver, Canada. 199 p.

Kennecott Exploration, 2019, Oreo Mountain Project Handover Memo: Unpublished report to Tubutulik Mining Company, 11 p. (Held by D.A. Hedderly-Smith, Poulsbo, Washington)

Kerin, L.J., 1976, The reconnaissance petrology of the Mt. Fairplay igneous complex: Fairbanks, Alaska, University of Alaska Fairbanks, M.S. thesis, 95 p., 5 plates, 4 sheets.

Newberry, R.J., 2020, The Mount Fairplay igneous complex: Alaska Division of Geological \& Geophysical Surveys Preliminary Interpretive Report 2020-1, 32 p. https://doi.org/10.14509/30463

Singer, D.A., Curtin, G.C., and Foster, H.L., 1976, Mineral resources map of the Tanacross Quadrangle, Alaska: U.S. Geological Survey Miscellaneous Field Studies Map 767-E, 1 sheet, scale 1:250,000.

U.S. Geological Survey, 2018, Alaska Resource Data File (ARDF). Online link (https://ardf. wr.usgs.gov; updated March 2018). 
Werdon, M.B., Athey, J.E., and Twelker, Evan, 2021, Alaska's mineral industry 2019: Alaska Division of Geological \& Geophysical Surveys Special Report 75, 69 p. https://doi. org/10.14509/30658

Wypych, Alicja, Naibert, T.J., Athey, J.E., Newberry, R.J., Sicard, K.R., Twelker, Evan, Werdon, M.B., Willingham, A.L., and Wyatt, W.C., 2018, Major-oxide and trace-element geochemical data from rocks collected in 2018 for the Northeast Tanacross project, Tanacross C-1, C-2, D-1, and D-2 quadrangles, Alaska: Alaska Division of Geological \& Geophysical Surveys Raw Data File 2018-4, 4 p. https://doi.org/10.14509/30113

Wypych, Alicja, Twelker, Evan, Naibert, T.J., Athey, J.E., Newberry, R.J., Lopez, J.A., Regan,
S.P., Sicard, K.R., Wildland, A.D., and Wyatt, W.C., 2019, Major-oxide and trace-element geochemical data from rocks collected in 2019 for the Eastern Tanacross project, Tanacross and part of Nabesna quadrangles, Alaska: Alaska Division of Geological \& Geophysical Surveys Raw Data File 2019-8, 3 p. https://doi. org/10.14509/30267

Wildland, A.D., Wypych, Alicja, Regan, S.P., and Holland, Mark, 2021, U-Pb zircon ages from bedrock samples collected in the Tanacross and Nabesna quadrangles, eastern Alaska: Alaska Division of Geological \& Geophysical Surveys Preliminary Interpretive Report 2021-4, 47 p. https://doi.org/10.14509/30732 